This manuscript is a preprint and has been submitted for publication in Ore Geology Reviews. The manuscript has not yet been reviewed. Please note that the manuscript has not been formally accepted for publication. Subsequent versions of this manuscript may have slightly different content. If accepted, the final version of this manuscript will be available via the 'Peer reviewed Publication DoI' link on the right-hand side of this webpage. Please feel free to contact the author; feedback is welcomed. 


\title{
Iron oxide copper-gold (IOCG) deposits - a review (part 1): settings, mineralogy, ore geochemistry, and classification within the $\mathrm{Cu}-\mathrm{Au}-\mathrm{Fe}$ ( \pm Co, REE) deposit family
}

\author{
Roger G. Skirrow ${ }^{1}$
}

Geoscience Australia, GPO Box 378, Canberra, ACT Australia 2601

\section{Graphical Abstract}

Classification of Cu-Au-Fe (CGI) deposits (including IOCG and ISCG deposits)

\begin{tabular}{|l|l|l|l|l|l|}
\hline \multirow{2}{*}{ Setting } & Timing & $\begin{array}{l}\text { Geochemical sub- } \\
\text { type }\end{array}$ & $\begin{array}{l}\text { Mineralogical-redox } \\
\text { sub-type }\end{array}$ & Key examples & Previous classification \\
\hline \multirow{2}{*}{ Orogenic-related CGI } & Syn-orogenic & CGI-Co & $\begin{array}{l}\text { Reduced to intermediate- } \\
\text { redox IOCG \& ISCG }\end{array}$ & $\begin{array}{l}\text { Sequeirinho, } \\
\text { Eloise }\end{array}$ & magnetite-IOCG \\
\cline { 2 - 6 } & CGI-Co-REE & $\begin{array}{l}\text { Intermediate-redox to } \\
\text { oxidised IOCG }\end{array}$ & Ernest Henry & $\begin{array}{l}\text { magnetite- \& } \\
\text { magnetite+hematite-IOCG }\end{array}$ \\
\cline { 2 - 6 } & Post-orogenic & CGI-REE & Oxidised IOCG & Olympic Dam & hematite-IOCG \\
\hline \multirow{2}{*}{ Arc-hosted CGI } & $\begin{array}{l}\text { Pre-orogenic, } \\
\text { syn-subduction }\end{array}$ & CGI (low Co, REE) & $\begin{array}{l}\text { Reduced, intermediate- } \\
\text { redox \& oxidised IOCG \& } \\
\text { ISCG }\end{array}$ & $\begin{array}{l}\text { Candelaria, } \\
\text { Mantoverde }\end{array}$ & $\begin{array}{l}\text { magnetite-, } \\
\text { magnetite+hematite- \& } \\
\text { hematite-IOCG }\end{array}$ \\
\hline
\end{tabular}

IOCG = iron oxide $\mathrm{Cu}$-Au deposits, ISCG = iron sulfide $\mathrm{Cu}-\mathrm{Au}$ deposits (= low-Fe-oxide $\mathrm{Cu}$-Au deposits) CGI-Co deposits are enriched in $\mathrm{Co} \pm \mathrm{Ni}, \mathrm{Bi}, \mathrm{Se}, \mathrm{Te}$ CGI-REE deposits are enriched in REE $\pm U, F, B a$

\begin{abstract}
Characteristics of ten of the world's metallogenic provinces hosting iron oxide $\mathrm{Cu}-\mathrm{Au}$ (IOCG) deposits have been critically assessed, including geochronology, geological and tectonothermal evolution, alteration-mineralisation parageneses, and ore geochemistry. A new classification framework is proposed in which IOCG deposits form the major part of a global family of $\mathrm{Cu}-\mathrm{Au}-$ $\mathrm{Fe}( \pm \mathrm{Co}, \mathrm{REE})$ or CGI deposits that also includes Fe-rich $\mathrm{Cu}$-Au deposits lacking significant iron oxides. The CGI family is subdivided on the basis of combined tectonic setting, ore geochemistry, and oxidation state of ore-related mineralogy. Three subtypes of CGI deposits have elevated REE $\pm \mathrm{U}, \mathrm{F}$ and $\mathrm{Ba}$ and/or enrichments in $\mathrm{Co}( \pm \mathrm{Ni}, \mathrm{Bi}, \mathrm{Se}, \mathrm{Te})$, with known deposits occurring in Precambrian syn- and post-orogenic settings. A fourth subtype of CGI deposits generally lacks significant enrichments in REE, U, F, Ba, Co, Ni, Bi, Se and Te and occur mainly in Phanerozoic Andean type magmatic arc settings. The REE- and/or Co-rich CGI deposit subtypes are geologically and geochemically distinct from porphyry $\mathrm{Cu}(-\mathrm{Au})$, skarn $\mathrm{Fe}-\mathrm{Cu}$ and iron oxideapatite (IOA) deposits, although there are some shared features. The low-REE-U-Co arc-hosted
\end{abstract}

\footnotetext{
${ }^{1}$ Formerly Geoscience Australia; current contact: roger.skirrow@gmail.com
} 
CGI deposits have more in common with other arc-hosted $\mathrm{Cu}$-Au deposit types, and may differ genetically from the REE-U- and/or Co-rich CGI deposits.

Many of the world's major IOCG-bearing metallogenic provinces host representatives of the synorogenic CGI deposit group. In some cases syn-orogenic settings evolved over a few 10s of millions of years to post-orogenic settings via a switch from compressional to extensional tectonic regimes. CGI deposits in arc-hosted settings differ from those in orogenic-related settings in forming during extension/transtension of continental margin magmatic arcs, mostly prior to inversion tectonics in the case of the Mesozoic Andean deposits. Metallogenic provinces hosting CGI deposits in all three settings are characterised by the coincidence in space and time between sedimentary \pm volcanic basins and intrusive \pm volcanic magmatism. Extended continental margin basins and later bimodal magmatism with $\mathrm{A}$ - and high-temperature I-type igneous rocks are characteristic of the syn- and post-orogenic settings, inboard of craton paleo-margins. In contrast, arc-hosted CGI deposits formed where back-arc basins were overprinted by syn-mineralisation calc-alkaline dominantly intermediate-composition magmatism.

Other features shared by the CGI including IOCG deposits in all three settings include the following.

- A metal association of both $\mathrm{Cu}$ and $\mathrm{Au}$ with highly elevated $\mathrm{Fe}$ (e.g. 10-60 wt \% Fe), as abundant Fe oxides and/or Fe sulfides and/or Fe-rich silicates, with sufficient $\mathrm{Cu}-\mathrm{Au}$ to be classed as a resource.

- A spectrum of oxidation states of ore-related hydrothermal mineralogy in many provinces, from reduced (e.g. pyrrhotite-chalcopyrite \pm magnetite \pm Fe-silicate-bearing) through intermediate-redox (e.g. magnetite-pyrite-chalcopyrite-bearing) to oxidised (e.g. hematite-pyrite-bornite \pm chalcocite \pm sulfate minerals).

- Minor elements (REE, U, F, Ba, Co, Ni, Mo, Bi, Se, Te) that are variably enriched in three of the four subtypes of CGI deposits, correlating with both redox state and geotectonic settings (reduced CGI-Co deposits in syn-orogenic settings; intermediate-redox CGI-CoREE deposits in syn-orogenic settings; oxidised CGI-REE deposits in post-orogenic settings); deposits of the fourth, arc-hosted, subtype have generally low levels of these minor elements.

- Paragenetically early $\mathrm{Na} \pm$ Ca-rich hydrothermal alteration (generally in regional-scale alteration zones) followed by combinations of Fe-, Ca- and K-rich minerals that accompanied or preceded $\mathrm{Cu}-\mathrm{Au}$ mineralisation together with volatile-bearing minerals (e.g. carbonate $\left(\mathrm{CO}_{2}\right)$, apatite $(\mathrm{P})$, fluorite $(\mathrm{F})$, barite $\left(\mathrm{SO}_{4}\right)$, tourmaline $\left.(\mathrm{B})\right)$.

- A paucity of hydrothermal quartz and Mg-rich hydrothermal minerals in the IOCG members of the $\mathrm{Cu}-\mathrm{Au}-\mathrm{Fe}$ family, but abundant quartz in many of the Fe-oxide-poor members.

It is argued in this and a companion paper reviewing the fluids and ore genesis that it is the special combinations of basinal-derived and magmatic/igneous-derived inputs to the deposits that produces the distinctive range of characteristics of $\mathrm{Cu}-\mathrm{Au}-\mathrm{Fe}( \pm \mathrm{Co}, \mathrm{REE})$ deposits. 


\section{Introduction}

The diverse group of iron oxide copper-gold (IOCG) deposits has been one of the most contentious classes of ore deposits since its recognition as a new type in the mid 1980s to early 1990s. Central to the debates have been the issues of definition, classification, the roles of magmatic versus and non-magmatic sources of fluids and metals, and tectonic settings. Early studies (e.g. Meyer, 1988) noted similarities between the giant Olympic Dam Cu-U-Au deposit, discovered in 1975 in South Australia, and iron oxide- and apatite-rich deposits of the southeast Missouri and Kiruna districts (USA, Sweden), and the Bayan Obo magnetite-REE deposit in China. Hitzman et al. (1992) included a number of other iron oxide-rich deposits in first defining the 'Proterozoic iron oxide (Cu-U-Au-REE)' class of ore deposits, and proposed a preliminary model involving extensional tectonic settings. Subsequently, a large number of highly diverse deposits, some newly discovered and others re-classified, have been included within an expanding group of IOCG deposits.

Despite major efforts to clarify and tighten the definition of IOCG deposits and to understand their settings (e.g. reviews by Sillitoe, 2003; Williams et al., 2005; Corriveau, 2007; Groves et al., 2010; Barton, 2013), there remain many unresolved first-order problems of definition and classification. Some of these issues stem from the IOCG name itself, which describes the mineralogy (iron oxide) associated with the principal ore metals (copper, gold) in the deposits. This terminology contrasts with many other well known deposit types such as porphyry $\mathrm{Cu}$, volcanic-hosted massive sulfide $\mathrm{Zn}-\mathrm{Pb}$ - $\mathrm{Cu}$, orogenic $\mathrm{Au}$, epithermal $\mathrm{Au}$, etc, which include their principal ore metals and an aspect of either their mode of origin or the ore depositional environment. As a consequence of the wide-embracing IOCG name, deposits of likely fundamentally different origins (e.g. magmatic-hydrothermal versus non-magmatic fluid or metal sources) have been included by some workers in the IOCG family.

Also problematic has been the variance in the definitions of the required grades of copper and gold to qualify as IOCG deposits. Several workers have proposed broad definitions of IOCG deposits such that some iron oxide-rich deposits with little or no copper or gold are considered part of the IOCG 'family' as possible 'end-members' or as 'affiliated' deposits (e.g. Hitzman et al., 1992; Williams et al., 2005; Corriveau, 2007; Barton, 2013). For example, Barton (2013) included a range of iron oxide-rich deposits lacking, or with sub-economic levels of, $\mathrm{Cu}$-Au-REE-P-Ag-U-Co as part of an 'iron oxide (-Cu-Au-REE-P-Ag-U-Co) clan'. Groves et al. (2010) addressed this and other problems relating to the extreme diversity of deposits previously classified as IOCG deposits by defining a sub-group of 'IOCG sensu stricto' large deposits ( $>100 \mathrm{Mt}$ of ore) with economic $\mathrm{Cu}$ and $\mathrm{Au}$ within a broader group of 'iron oxide-associated' deposits. Their broader group included some alkaline intrusion- and carbonatite-related deposits such as Palabora $(\mathrm{Cu})$ and Vergenoeg (magnetite-fluorite), considered to be end-members of the 'iron oxide-associated deposits'. The definition of IOCG deposits by Williams et al. (2005) was revised by Groves et al. (2010) as follows: (1) $\mathrm{Cu}+\mathrm{Au}$ as economic metals, (2) hydrothermal characteristics and structural controls, commonly with breccias, (3) abundant low-Ti Fe oxides (magnetite, hematite) and/or Fe silicates (grunerite, Fe actinolite, fayalite), (4) LREE enrichment and low-S sulfides, including chalcopyrite-bornite-chalcocite and pyrrhotite, (5) lack of abundant syn-sulfide quartz veins and alteration that commonly includes a decreased $\mathrm{SiO}_{2}$ content of wall rocks, (6) a temporal relationship with magmatism, yet no close spatial association with causative intrusions. 
While consistent with the definition of IOCG deposits of Williams et al. (2005), the classification scheme of Williams (2010) included 'hematite-group' and 'magnetite-group' IOCG deposits, and differentiated these from several types of 'affiliated deposits' (low-Fe-oxide $\mathrm{Cu}-\mathrm{Au}$; Co$\mathrm{As} \pm \mathrm{Au} \pm \mathrm{Ag} \pm \mathrm{U} \pm \mathrm{Fe}$-oxide deposits with low $\mathrm{Cu}$; and $\mathrm{Fe}$ oxide- $\mathrm{U}$ deposits with low $\mathrm{Cu}$ ). Iron oxideapatite (IOA) deposits of the Kiruna type were excluded from the 'IOCG and affiliated deposits' grouping of Williams (2010), as were several types of 'orthomagmatic/magmatic-hydrothermal iron oxide \pm apatite $\pm \mathrm{Cu} \pm \mathrm{Au} \pm$ rare metal deposits' such as Palabora (Cu), Bayan Obo (Fe, REE), magnetite-rich porphyry-related $\mathrm{Cu}$-Au deposits such as Ertsberg-Grasberg, and the Vergenoeg magnetite-fluorite deposit. Following Groves et al. (2010), yet another grouping was proposed by Porter (2010) termed 'iron oxide associated-alkali altered (IOAA) mineralised systems', which incorporate: IOCG sensu stricto deposits, IOA deposits, carbonatite and alkaline igneous-related iron oxide deposits, and a subgroup of 'miscellaneous deposits sharing characteristics of both iron oxide alkali-altered systems and another ore system'. Finally, Corriveau et al. $(2010,2016)$ refined the IOAA scheme of Porter (2010) and considered 'iron oxide and alkali-calcic alteration ore systems' as including IOCG deposits (with economic $\mathrm{Cu} \pm \mathrm{Au}, \mathrm{Ag}, \mathrm{REE}, \mathrm{U}$ ) and five other subtypes of IOAA systems (iron oxide \pm apatite \pm REE deposits; albitite-hosted U or Au; skarnhosted $+\mathrm{K}$-skarn \pm Fe oxides with base and precious metals; low-Cu IOCG variants with Au, Co, $\mathrm{As}, \mathrm{Bi}, \mathrm{Ag}$; and 'skarn' alteration).

The foregoing overview of previous classifications of IOCG and 'affiliated' deposits highlights the challenges in defining and categorising the highly diverse deposits of $\mathrm{Cu}-\mathrm{Au}$ associated with iron oxides and/or iron sulfides. As noted by Groves et al. (2010) the "IOCG group of deposits ... has progressively become too-embracing ... ", and "consideration of this broad group as a whole obscures the critical features of the IOCG sensu stricto deposits ...". This appears still to be the case. The aim of this two-part review is to critically re-examine IOCG deposits from a fresh perspective using newly available data so as to identify the diagnostic geological and geochemical characteristics and ore-forming processes of deposits previously included in the IOCG class. Ultimately, it is intended to clarify the issue of 'what is an IOCG deposit' based on an improved understanding of the fundamental processes of ore formation.

This contribution commences with a summary of the general features of the deposits considered in this review and then synthesises the principal geological characteristics and tectonic settings of global provinces hosting the diverse range of deposits previously described as IOCG deposits. Detailed descriptions of ten metallogenic provinces and geochronological constraints are presented in the Supplementary Information. This is followed by descriptions of hydrothermal mineral assemblages and their paragenetic sequences, including proximal and regional alteration. The next section addresses the ore geochemistry of the $\mathrm{Cu}-\mathrm{Au}-\mathrm{Fe}$ deposits using published data, and links this to the geotectonic settings and mineralogical variations. Finally, the findings are integrated within a new classification and definition of the global family of $\mathrm{Cu}-\mathrm{Au}-\mathrm{Fe}$ ( \pm Co, REE) deposits which includes IOCG deposits. An accompanying contribution reviews the sources of ore components and discusses the ore-forming processes and origins of $\mathrm{Cu}-\mathrm{Au}-\mathrm{Fe}( \pm$ Co, REE) deposits (Skirrow, in prep.). 


\section{General features and global distribution of $\mathrm{Cu}-\mathrm{Au}-\mathrm{Fe}$ including IOCG deposits}

\subsection{General features}

This review considers a group of deposits including the $\mathrm{Cu}$-Au-rich members of the variouslydescribed IOCG class as well as iron oxide-poor $\mathrm{Cu}-\mathrm{Au}$ deposits occurring in the same metallogenic provinces. This family of Fe-oxide-rich and Fe-oxide-poor $\mathrm{Cu}-\mathrm{Au}$ deposits, recognised by Haynes (2000), is herein termed $\mathrm{Cu}-\mathrm{Au}-\mathrm{Fe}( \pm \mathrm{Co}, \mathrm{REE})$ abbreviated to CGI deposits, but the widely used term IOCG deposit is retained where appropriate. Although the term $\mathrm{Cu}-\mathrm{Au}-$ $\mathrm{Fe}( \pm \mathrm{Co}, \mathrm{REE})$ deposit is non-specific as an ore deposit class, it is proposed that qualifiers are used together with ' $\mathrm{Cu}-\mathrm{Au}-\mathrm{Fe}( \pm \mathrm{Co}, \mathrm{REE})$ ' to identify the characteristic geological settings, mineralogy and geochemical compositions of particular sub-types of CGI deposits including IOCG deposits. The $\mathrm{Cu}-\mathrm{Au}-\mathrm{Fe}( \pm \mathrm{Co}, \mathrm{REE})$ family of deposits includes the following four subtypes, as described in later sections: Co-rich REE-poor; Co-poor REE-rich; Co-REE-rich; and $\mathrm{Cu}-\mathrm{Au}-\mathrm{Fe}$ deposits without significant enrichments in Co or REE which occur mainly in Andean type magmatic arc geological settings.

Based on the current review of the geology and deposits in ten global provinces together with previous descriptions (e.g. Hitzman et al., 1992; Haynes, 2000; Sillitoe, 2003; Williams et al., 2005; Corriveau, 2007; Barton, 2013) the $\mathrm{Cu}-\mathrm{Au}-\mathrm{Fe}( \pm \mathrm{Co}, \mathrm{REE})$ deposits considered herein are characterised by the following general features. These combined attributes distinguish the $\mathrm{Cu}$ $\mathrm{Au}-\mathrm{Fe}( \pm \mathrm{Co}, \mathrm{REE})$ family of deposits from other well known ore deposit types such as porphyry $\mathrm{Cu}(-\mathrm{Au})$, skarn $\mathrm{Fe}$ and $\mathrm{Cu}$, and IOA deposits.

- Deposit- and orebody-scale spatial association of copper-gold resources with iron-rich rocks (e.g. 10-60 wt \% Fe), with iron hosted by low-Ti oxides (magnetite and/or hematite), and/or sulfides and/or other iron-rich minerals; oxide/sulfide ratios vary greatly between deposits and within deposits.

- Copper sulfides and gold are associated with moderate to strong enrichments of several of the following groups of elements which may attain ore grade in some deposits: Ag, Co, $\mathrm{Ni}, \mathrm{Bi}, \mathrm{Se}, \mathrm{Te}$, In and/or LREE, U, F, Ba, Mo; in most deposits there is little or no significant enrichment in $\mathrm{Zn}, \mathrm{Pb}, \mathrm{Cd}, \mathrm{As}, \mathrm{Sb}, \mathrm{W}, \mathrm{Sn}, \mathrm{Ta}, \mathrm{Nb}, \mathrm{Li}$, although rare examples of outer/distal $\mathrm{Pb}$-Zn-As-rich zones are known.

- Copper and iron sulfides and gold either post-dated, or were deposited synchronously with, the iron oxides and silicates; iron sulfides are pyrrhotite and/or pyrite, whereas the copper sulfides include chalcopyrite, bornite and chalcocite which are zoned in some deposits; districts with $\mathrm{Cu}-\mathrm{Au}-\mathrm{Fe}( \pm \mathrm{Co}, \mathrm{REE})$ deposits may contain a wide range of oxidesulfide assemblages from pyrrhotite \pm magnetite-rich or pyrite \pm magnetite-rich to pyrite \pm hematite-rich; Fe-oxide-rich $\mathrm{Cu}-\mathrm{Au}$ deposits that lack pyrite or pyrrhotite are also known.

- Deposit- and orebody-scale hydrothermal alteration in higher temperature settings generally comprises variants of iron, potassic and calcic mineral assemblages including magnetite, biotite, Ca-amphibole (e.g. actinolite-tremolite), Ca- and/or Fe-carbonate, Kfeldspar, and much less common Ca-Fe-rich clinopyroxene, garnet, and iron silicates.

- In lower temperature settings the proximal alteration with $\mathrm{Fe}-\mathrm{Cu}-\mathrm{Au}$ minerals comprises combinations of hematite, sericite/phengite, chlorite, and Ca- and/or Fe-carbonate. 
- Some Cu-Au-Fe ( \pm Co, REE) deposits contain hydrothermal barite, fluorite, apatite, allanite, molybdenite, tourmaline, and a range of $U$ - and REE-bearing minerals accompanying $\mathrm{Cu}-\mathrm{Au}$ mineralisation; anhydrite is rarely reported, and epidote is generally inconspicuous.

- Paragenetically early sodic alteration (albitic plagioclase, scapolite) is uncommon in most $\mathrm{Cu}-\mathrm{Au}$ ore zones but is characteristic of distal and regional alteration zones where it may be accompanied by Ca-amphiboles, Ca-clinopyroxenes, and minor titanite and magnetite; breccias and brittle-ductile structures are common in association with regional $\mathrm{Na}(-\mathrm{Ca})$ alteration; calcic-iron ( $\mathrm{Ca}-\mathrm{Fe}$ ) and potassic-iron (K-Fe) alteration typically overprints sodic alteration.

- Hydrothermal quartz is generally not abundant with iron oxide-rich $\mathrm{Cu}-\mathrm{Au}$ mineralisation but may be present within iron oxide-poor, iron sulfide-rich, $\mathrm{Cu}-\mathrm{Au}$ zones of the same deposits or in separate iron oxide-poor deposits.

- The higher temperature deposits are commonly hosted by brittle-ductile shear zones and related structures including breccias, whereas deposits in lower temperature settings occur in brittle deformation structures such as faults, veins and breccia zones.

- Two (or more) fluids have been identified as related to $\mathrm{Fe}$ and $\mathrm{Cu}-\mathrm{Au}$ mineralisation in many deposits, including hypersaline and lower salinity brines; $\mathrm{CO}_{2}$-rich fluids are also commonly present; isotopic and geochemical evidence suggests contributions of water, halogens and sulfur from non-magmatic as well as magmatic or leached-igneous rock sources.

- Proximal intrusive igneous rocks contemporaneous with $\mathrm{Cu}-\mathrm{Au}-\mathrm{Fe}$ mineralisation are not present at many deposits or are volumetrically minor; however, in specific settings (e.g. Andean) there are close spatial and temporal relationships with intrusions of generally intermediate composition; in other $\mathrm{Cu}-\mathrm{Au}$-Fe provinces regional magmatism was broadly coeval with $\mathrm{Cu}-\mathrm{Au}$ mineralisation and tends to be bimodal in composition.

- Almost all Cu-Au-Fe ( \pm Co, REE) deposits occur within volcano-sedimentary basinal host rocks that have been metamorphosed at low to medium grades either before or during $\mathrm{Cu}-\mathrm{Au}-\mathrm{Fe}$ ore formation; local host rocks are highly variable and include metasedimentary, metavolcanic, and igneous rocks ranging from mafic to felsic in composition.

Any proposed holistic genetic model(s) for this group of $\mathrm{Cu}-\mathrm{Au}-\mathrm{Fe}( \pm \mathrm{Co}, \mathrm{REE})$ deposits must account for all of the key features listed above. This review leads to the conclusion that there are two fundamentally different types of $\mathrm{Cu}-\mathrm{Au}-\mathrm{Fe}( \pm \mathrm{Co}, \mathrm{REE})$ deposits that formed in separate geotectonic settings, yet both types involved contributions of basin-derived (non-magmatic) and magmatic-hydrothermal or igneous rock-derived ore-forming components. It is proposed here and in the companion paper that it is these variations in settings and differing contributions of input fluids and metals that result in the great diversity of $\mathrm{Cu}-\mathrm{Au}-\mathrm{Fe}( \pm \mathrm{Co}, \mathrm{REE})$ deposits.

\subsection{Global distribution}

The major $\mathrm{Cu}-\mathrm{Au}-\mathrm{Fe}( \pm \mathrm{Co}, \mathrm{REE})$ including IOCG deposits occur in widely in space and time, as summarised in Figure 1. The current review considers ten of the major $\mathrm{Cu}-\mathrm{Au}-\mathrm{Fe}( \pm \mathrm{Co}, \mathrm{REE})$ metallogenic provinces and their mineral deposits, including (in age order from Archean to Mesozoic): Carajás province in northern Brazil; Guelb Moghrein deposit in Mauritania; 
Kiruna/Norbotten province in northern Sweden and Finland; Great Bear magmatic zone in northwest Canada; Tennant Creek province in northern Australia; Kangdian province in southwest China and probable extension in Vietnam including the Sin Quyen deposit; eastern Gawler Craton and subjacent Curnamona Province in southern Australia; Cloncurry province in northern Australia; Khetri province in northwest India; and the Andean province in Chile and Peru. The background image in Figure 1 shows global seismic velocity (shear wave) anomalies at a depth of $165 \mathrm{~km}$ (Lu et al., 2019), which is used here as a proxy for the present day boundaries of cratonic blocks at this depth. Although the spatial resolution is relatively low, it is strikingly evident that almost all of the major $\mathrm{Cu}-\mathrm{Au}-\mathrm{Fe}( \pm \mathrm{Co}, \mathrm{REE})$ provinces occur close to the gradient (highlighted in white) between 'fast' and 'slow' velocity. This relationship is less evident for the Mesozoic provinces in South America and, arguably, the Kangdian province in southwest China. Groves et al. (2010) noted a similar relationship between craton margins and the Precambrian IOCG 'sensu stricto' deposits; the current investigation supports this proposal with additional provinces and data. Furthermore, in Australia this spatial relationship has been shown more precisely by Hoggard et al. (2020) who demonstrated that the large $\mathrm{Cu}-\mathrm{Au}$ deposits of the eastern Gawler Craton and the Cloncurry provinces lie within $\sim 100 \mathrm{~km}$ of the surface projection of the $170 \mathrm{~km}$ depth contour of the lithosphere-asthenosphere boundary (LAB). The same spatial association of the LAB with the $\mathrm{Cu}-\mathrm{Au}-\mathrm{Fe}$ deposits considered in the present review is evident globally (Czarnota, Hoggard, Skirrow, in prep.), as it is for sedimentary basin-hosted resources of $\mathrm{Zn}, \mathrm{Pb}$ and $\mathrm{Cu}$ (Hoggard et al., 2020).

In contrast, the locations of major porphyry $\mathrm{Cu}(-\mathrm{Au})$ metallogenic provinces are almost all above global domains of relatively low seismic velocity at $165 \mathrm{~km}$ depth. The major IOA provinces range in age from Paleoproterozoic (e.g. Kiruna/Norbotten province) and Mesoproterozoic (e.g. southeast Missouri) through Paleozoic (e.g. Bafq, Iran) to Mesozoic (e.g. Chilean Andes, and Middle-Lower Yangtze Belt, China) and even Cenozoic (e.g. El Laco, Chile). Most are situated above relatively low velocity mantle but those in the Urals (Russia) are exceptions, and the IOA deposits of southeast Missouri and the Adirondacks (USA) are located, like the $\mathrm{Cu}-\mathrm{Au}-\mathrm{Fe}( \pm \mathrm{Co}$, REE) deposits, close to a cratonic margin. 




Figure 1. Locations of global major $\mathrm{Cu}-\mathrm{Au}-\mathrm{Fe}( \pm \mathrm{Co}, \mathrm{REE})$ (including IOCG) deposits and provinces, compared to iron oxide-apatite (IOA) and porphyry $\mathrm{Cu}-\mathrm{Au}(-\mathrm{Mo})$ deposits and provinces, plotted on background image of seismic velocity (shear wave) anomalies at $165 \mathrm{~km}$ depth relative to the ak135 reference model (from TX2019slab-S model of Lu et al., 2019). Blue areas represent anomalous fast seismic wave speeds representing depleted cratonic lithospheric mantle beneath Archean and Proterozoic cratons. Locations of deposits and metallogenic provinces based on Ghandi (2015), Sillitoe (2010) and references cited in the text and in the Supplementary Information. Abbreviations: Ch - Chandmani Uul deposit (Oyunjargal et al., 2020), R - Rosen deposit (Sillitoe et al., 2020).

\section{Three regional and tectonic settings of $\mathrm{Cu}-\mathrm{Au}-\mathrm{Fe}( \pm \mathrm{Co}, \mathrm{REE})$ provinces}

The timing of regional geological events in relation to $\mathrm{Cu}-\mathrm{Au}-\mathrm{Fe}$ mineralisation is summarised in Figure 2 for six of the world's major metallogenic provinces containing large IOCG deposits. Detailed descriptions of regional and hydrothermal events in these provinces along with 4 others are presented in the Supplementary Information, and summary information is given in Table 1. Event time spans shown in Figure 2 represent the main bodies of available geochronological data for each event, with emphasis on ages determined with robust geochronometers such as $\mathrm{U}-\mathrm{Pb}$ and U-Th-Pb isotope analyses of zircon, titanite and monazite, and Re-Os isotope analysis of molybdenite. Additional constraints from ${ }^{40} \mathrm{Ar} /{ }^{39} \mathrm{Ar}$ dating have been utilised for hydrothermal minerals in some provinces. Uncertainties on individual ages are given in the detailed compilations of geochronological data the Supplementary Information. The timing and character of deformation/tectonism events have been largely taken from the literature, supplemented by further interpretation in some provinces as described in the Supplementary Information. 


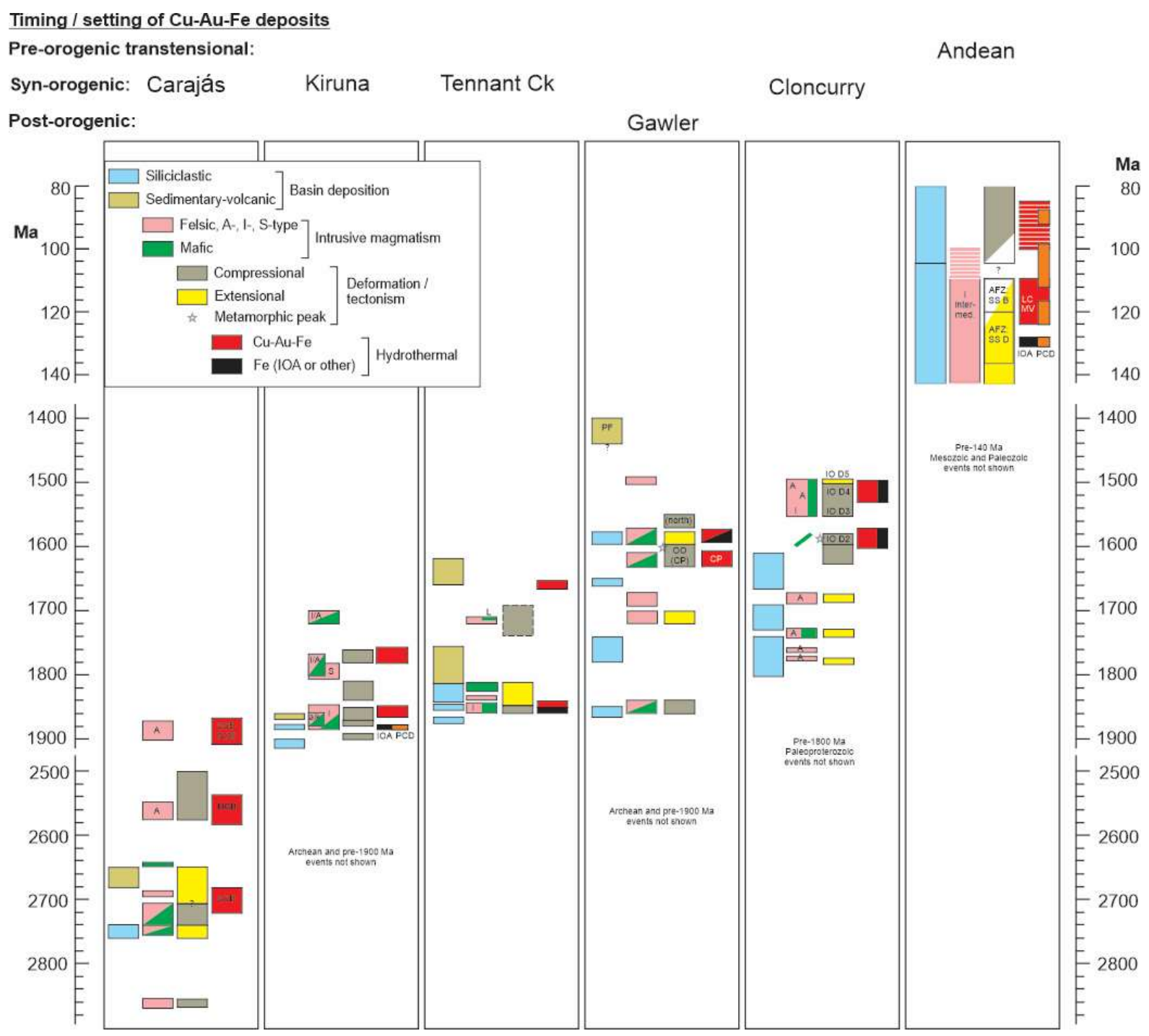

Figure 1. Synthesis of geochronological data for mineralisation, tectonic, magmatic and supracrustal depositional events in key provinces with $\mathrm{Cu}-\mathrm{Au}-\mathrm{Fe}( \pm \mathrm{Co}$, REE) including IOCG deposits. The Kiruna/Norbotten and Mesozoic Andean provinces also contain well known IOA deposits and smallmedium sized porphyry $\mathrm{Cu}(-\mathrm{Au})$ deposits. Note breaks in time scale. For sources of data and named rock units see the Supplementary Information. Abbreviations for intrusive magmatism: A - A-type felsic, I - Itype felsic, L - lamprophyre, S - S-type felsic, alk - alkaline. Other abbreviations: AFZ - Atacama Fault Zone, CP - Curnamona Province Cu-Au deposits, IO - Isan Orogeny, IOA - iron oxide apatite deposits, LC La Candelaria Cu (-Au), MV - Mantoverde Cu (-Au) deposit, NCB - Northern Copper Belt, 00 (CP) Olarian Orogeny in Curnamona Province, PCD - porphyry Cu deposits, SCB - Southern Copper Belt, SS B strike-slip brittle, SS D - strike-slip ductile. 
Table 1. Summary of $\mathrm{Cu}-\mathrm{Au}-\mathrm{Fe}( \pm \mathrm{Co}, \mathrm{REE})$ metallogenic provinces and their mineral deposits. Data sources are given in the Supplementary Information. Deposit type abbreviations: CGI - Cu-Au-Fe ( \pm Co, REE) including IOCG deposits, IOA - iron oxide apatite deposits, PCD - porphyry Cu deposits, SSC - sedimenthosted stratiform $\mathrm{Cu}$ deposits.

\begin{tabular}{|c|c|c|c|c|c|}
\hline Province & $\begin{array}{l}\text { Basin rocks hosting } \\
\text { CGI deposits }\end{array}$ & $\begin{array}{l}\text { Magmatism syn- } \\
\text { CGI (name of } \\
\text { suite) }\end{array}$ & Deposit types & $\begin{array}{l}\text { Age of } \mathrm{Cu}-\mathrm{Au}-\mathrm{Fe} \\
\text { deposits }\end{array}$ & $\begin{array}{l}\text { Setting of } \mathrm{Cu}-\mathrm{Au}-\mathrm{Fe} \\
\text { deposits } \quad \# \quad \text { of } \\
\text { events) }\end{array}$ \\
\hline Carajás & $\begin{array}{l}\text { siliciclastics, BIF, felsic \& } \\
\text { mafic volcanics }\end{array}$ & $\begin{array}{l}\text { Bimodal, alkali- } \\
\text { calcic (I-type) } \\
\text { felsics \& } \\
\text { A-types } \\
\text { (Planalto) }\end{array}$ & $\begin{array}{l}\text { CGI, Au-PGE, Ni, } \\
\mathrm{Fe}(\mathrm{BIF}) \& \text { late } \\
\text { granite-related } \\
\mathrm{Cu}-\mathrm{Au}\end{array}$ & $\begin{array}{l}\text { Neoarchean \& } \\
\text { Paleoproterozoic }\end{array}$ & $\begin{array}{lr}\text { syn-orogenic } & (2, \\
\text { Neoarchean); } & \text { post- } \\
\text { orogenic } & (1, \\
\text { Paleoprot. } & \end{array}$ \\
\hline Guelb Moghrein & $\begin{array}{lr}\text { siliciclastics, } & \text { BIF, } \\
\text { carbonate-rich, } & \text { mafic } \\
\text { volcanics } & \end{array}$ & none recognised & CGI & $\begin{array}{l}\text { Neoarchean/early } \\
\text { Paleoproterozoic, }\end{array}$ & syn-orogenic (1) \\
\hline Kiruna/Norbotten & $\begin{array}{l}\text { Intermediate-mafic- } \\
\text { felsic volcanic-rich, } \\
\text { minor siliciclastics, } \\
\text { carbonate \& graphite }\end{array}$ & $\begin{array}{l}\text { Calc-alkaline to } \\
\text { alkaline, bimodal } \\
\text { (Haparanda \& } \\
\text { Perthite- } \\
\text { Monzonite) }\end{array}$ & $\begin{array}{l}\text { CGI, IOA, PCD, } \\
\text { VHMS, orogenic } \\
\mathrm{Au}\end{array}$ & Paleoproterozoic & syn-orogenic (2) \\
\hline $\begin{array}{l}\text { Great Bear } \\
\text { magmatic zone }\end{array}$ & $\begin{array}{l}\text { Intermediate-mafic- } \\
\text { felsic-volcanic-rich, } \\
\text { minor siliciclastics }\end{array}$ & $\begin{array}{l}\text { Calc-alkaline to } \\
\text { alkaline I-type, } \\
\text { and A-type } \\
\text { (various GBMZ) }\end{array}$ & $\begin{array}{l}\text { CGI, IOA, skarn, } \\
\text { albitite-U }\end{array}$ & Paleoproterozoic & $\begin{array}{l}\text { syn- to post-orogenic } \\
\text { (1) }\end{array}$ \\
\hline Tennant Creek & $\begin{array}{l}\text { Siliciclastics, hematitic } \\
\text { shale, minor felsic } \\
\text { volcanics, } \\
\text { carbonate }\end{array}$ & $\begin{array}{l}\text { I-type, bimodal } \\
\text { (Tennant Creek) }\end{array}$ & CGI & Paleoproterozoic & $\begin{array}{l}\text { syn- to post-orogenic } \\
\text { (2) }\end{array}$ \\
\hline $\begin{array}{l}\text { Gawler- } \\
\text { Curnamona }\end{array}$ & $\begin{array}{l}\text { Siliciclastics, minor } \\
\text { mafic \& felsic volcanics, } \\
\text { minor BIF, calc-silicates } \\
\text { \& scapolite }\end{array}$ & $\begin{array}{l}\text { Bimodal, high- } \\
\text { temperature I- } \\
\text { and A-type; minor } \\
\text { alkaline } \\
\text { (Hiltaba-GRV) }\end{array}$ & $\begin{array}{l}\text { CGI, minor Mo \& } \\
\mathrm{Au}-\mathrm{Mo} \text { (orogenic } \\
\mathrm{Au} \mathrm{or} \mathrm{IRG} \mathrm{\&} \\
\text { epithermal Ag to } \\
\text { west; Pb-Zn-Ag } \\
\text { to east) }\end{array}$ & $\begin{array}{l}\text { Early } \\
\text { Mesoproterozoic }\end{array}$ & $\begin{array}{l}\text { Major deposits post- } \\
\text { orogenic (1) }\end{array}$ \\
\hline Cloncurry & $\begin{array}{l}\text { Siliciclastics, } \\
\text { calcsilicates \& scapolite, } \\
\text { mafic \& felsic volcanics, } \\
\text { minor BIF; minor } \\
\text { graphite }\end{array}$ & $\begin{array}{l}\text { Bimodal, high- } \\
\text { temperature I- } \\
\text { and A-type } \\
\text { (Williams- } \\
\text { Naraku) }\end{array}$ & $\begin{array}{l}\text { CGI, Mo, Pb-Zn- } \\
\mathrm{Ag} \quad \text { (albitite-U, } \\
\text { skarn-REE-U and } \\
\text { orogenic? Au to } \\
\text { west) }\end{array}$ & $\begin{array}{l}\text { Early } \\
\text { Paleoproterzoic }\end{array}$ & $\begin{array}{l}\text { syn- to late-orogenic } \\
\text { (2) }\end{array}$ \\
\hline Kangdian & $\begin{array}{l}\text { Siliciclastics, carbonate- } \\
\text { rich, minor graphite }\end{array}$ & Mafic intrusive & CGI, SSC & $\begin{array}{l}\text { Paleo- to } \\
\text { Neoproterozoic }\end{array}$ & syn-orogenic (2) \\
\hline Khetri & $\begin{array}{l}\text { Siliciclastics, } \\
\text { calcsilicates \& scapolite }\end{array}$ & $\begin{array}{l}\text { Bimodal } \\
\text { (Erinpura, timing } \\
\text { unclear) }\end{array}$ & $\begin{array}{l}\text { CGI, SSC (Pb-Zn- } \\
\text { Ag and albitite-U } \\
\text { to south) }\end{array}$ & Neoproterozoic & syn-orogenic (1) \\
\hline $\begin{array}{l}\text { Chilean Iron Belt } \\
\text { and Peru }\end{array}$ & $\begin{array}{l}\text { Mafic-intermediate- } \\
\text { felsic volcanic-rich, } \\
\text { marine sediments }\end{array}$ & $\begin{array}{l}\text { Calc-alkaline } \\
\text { (Coastal } \\
\text { Batholith) }\end{array}$ & $\begin{array}{l}\text { CGI, IOA, Fe- } \\
\text { skarn, } \quad \text { PCD, } \\
\text { manto Cu-Ag }\end{array}$ & Cretaceous & $\begin{array}{l}\text { Syn-extensional pre- } \\
\text { orogenic to early- } \\
\text { orogenic (1) }\end{array}$ \\
\hline
\end{tabular}


This global review of ten metallogenic provinces has revealed three distinct lithostratigraphictectonothermal settings for the major $\mathrm{Cu}-\mathrm{Au}-\mathrm{Fe}( \pm \mathrm{Co}, \mathrm{REE})$ deposits: two related to major orogenic/tectonothermal events, and another where continental margin arcs were undergoing extension (Andean type). The orogenic-related setting of $\mathrm{Cu}-\mathrm{Au}-\mathrm{Fe}( \pm \mathrm{Co}$, REE) deposit formation is subdivided into syn-orogenic and post-orogenic settings. There may also exist hybrids of these settings, as described below. All three settings contain Fe-oxide-rich deposits that have been previously categorised as IOCG deposits, but each setting also contains Fe-sulfide-bearing $\mathrm{Cu} \pm$ $\mathrm{Au}$ deposits lacking significant Fe-oxides. The three settings are summarised below; for full referencing see the Supplementary Information.

\subsection{Syn-orogenic settings}

Many of the major $\mathrm{Cu}-\mathrm{Au}-\mathrm{Fe}( \pm \mathrm{Co}, \mathrm{REE})$ provinces occur in syn- to late-orogenic settings (henceforth grouped together as syn-orogenic), including Carajás, Cloncurry, Kangdian - Sin Quyen, Tennant Creek and probably Khetri. As detailed in the Supplementary Information these provinces exhibit similar sequences of regional geological events involving basin formation, then tectonic/orogenic processes leading to inversion of the basins, regional metamorphism of commonly high-temperature low-pressure style, and I- and/or A-type felsic and mafic bimodal magmatism that temporally overlaps with the tectonic/orogenic events. A common theme in the syn-late-orogenic settings is a change in tectonic style from early compressional tectonism to transpressional and thence in some cases to transtensional or extensional regimes. The extensional setting is described separately below, as the post-orogenic setting.

The volcanic-sedimentary basins in provinces with syn-orogenic $\mathrm{Cu}-\mathrm{Au}-\mathrm{Fe}( \pm \mathrm{Co}, \mathrm{REE})$ deposits typically are of continental to shallow marine rather than deep marine character, and commonly contain oxidised facies and strata with evidence of former evaporites, as well as Fe-rich lithologies such as mafic volcanics and banded iron formation. Carbonaceous units are volumetrically minor or absent in the host sequences but may be locally present at some deposits (Haynes, 2000). The basins generally formed in extended continental margin including passive margin settings.

Regional magmatism was broadly coeval with the formation of most syn-orogenic $\mathrm{Cu}-\mathrm{Au}-\mathrm{Fe}( \pm$ Co, REE) deposits although syn-mineralisation intrusions are rarely present within or subjacent to the $\mathrm{Cu}-\mathrm{Au}$ mineralisation. A few examples of syn-orogenic deposits appear to lack major synmineralisation magmatism (e.g. Osborne deposit, Cloncurry district). A- and/or high-temperature I-type felsic intrusive \pm volcanic rocks are commonly coeval with mafic to ultramafic intrusive \pm volcanic rocks that are weakly to moderately K-rich; calc-alkaline intermediate compositions are generally absent, as are highly alkaline igneous compositions, within the syn-mineralisation igneous complexes.

In the syn-orogenic provinces $\mathrm{Cu}-\mathrm{Au}-\mathrm{Fe}( \pm \mathrm{Co}, \mathrm{REE})$ mineralisation occurred synchronously with, or late within, an orogenic event as demonstrated by the available radiometric ages (Supplementary Information) and by the structural controls described in the literature for $\mathrm{Cu}$ $\mathrm{Au}-\mathrm{Fe}( \pm \mathrm{Co}, \mathrm{REE})$ deposits in each province. Brittle-ductile shear zones and breccias associated with shear zones, for example, are common sites for syn-tectonic hydrothermal alteration and $\mathrm{Cu}-\mathrm{Au}-\mathrm{Fe}( \pm \mathrm{Co}, \mathrm{REE})$ mineralisation in this regional setting. Several provinces experienced multiple $\mathrm{Cu}-\mathrm{Au}$ mineralising events 10 s to 100 s of millions of years apart. Other deposit types 
occurring in the same metallogenic provinces as the $\mathrm{Cu}-\mathrm{Au}-\mathrm{Fe}( \pm \mathrm{Co}, \mathrm{REE})$ deposits include: $\mathrm{Cu}(-$ $\mathrm{Au}$ ) deposits lacking abundant $\mathrm{Fe}$ oxides but containing significant Fe sulfides (termed iron sulfide $\mathrm{Cu}-\mathrm{Au}$ or ISCG deposits by Haynes, 2000; sedimentary and/or hydrothermal Fe oxide deposits and Fe-oxide-rich alteration of various origins; and less common mafic-ultramafic intrusion-hosted $\mathrm{Ni}-\mathrm{Cu}$ sulfide mineralisation (e.g. Carajás province). The low-oxide $\mathrm{Cu}(-\mathrm{Au})$ or ISCG mineralisation is represented variously as zones within deposits with abundant Fe oxides (e.g. Eloise, Osborne in Cloncurry province; $\mathrm{Cu}-\mathrm{Au}-\mathrm{Bi}$ zones outside ironstones at Orlando East and Gecko, Tennant Creek province) and as $\mathrm{Cu}(-\mathrm{Au})$ deposits that are spatially quite separate from the IOCG deposits (e.g. stratabound sediment-hosted $\mathrm{Cu}$ or 'SSC' deposits in the Kangdian and Khetri provinces). The Fe oxide deposits and Fe-oxide-rich alteration zones are an important feature of all of the syn-orogenic settings, and variously occur as zones with little or no $\mathrm{Cu}-\mathrm{Au}$ mineralisation within some IOCG/ deposits and as accumulations spatially quite separate from the $\mathrm{Cu}$-Au mineralisation. For example, in the Carajás province giant Fe ore deposits related to sedimentary BIF formed prior to the Cu-Au-Fe ( \pm Co, REE) deposits (Grainger et al., 2008), whereas massive magnetite deposits of hydrothermal origin occur in the Southern Copper Belt, separately from the large $\mathrm{Cu}-\mathrm{Au}-\mathrm{Fe}( \pm \mathrm{Co}, \mathrm{REE})$ deposits and also in some cases within the deposits associated with albite-actinolite alteration (e.g. Sequeirinho orebody in the Sossego deposit, Monteiro et al., 2008).

Several metallogenic provinces with syn-orogenic $\mathrm{Cu}-\mathrm{Au}-\mathrm{Fe}( \pm \mathrm{Co}, \mathrm{REE})$ deposits also host stratabound $\mathrm{Pb}-\mathrm{Zn}-\mathrm{Ag}$ deposits, or such deposits occur in adjacent basin provinces. For example, the Eastern Succession of the Mount Isa Inlier hosts both the Cloncurry $\mathrm{Cu}-\mathrm{Au}-\mathrm{Fe}$ syn-orogenic deposits and the Cannington and Pegmont $\mathrm{Pb}-\mathrm{Zn}-\mathrm{Ag}$ deposits which formed $>100$ m.y. prior to the Cu-Au-Fe deposits ( 1680-1670 Ma; see Sangster, 2020, and Spry \& Teale, 2021 and references therein). Similarly, the Curnamona Province hosts the giant Broken Hill Pb-Zn-Ag deposit ( $1690 \mathrm{Ma}$, Page et al., 2005) in the eastern part of the province as well as $\mathrm{Cu}-\mathrm{Au}(-\mathrm{Mo})$ mineralisation in the Olary Domain to the west ( 1630-1605 Ma, Skirrow et al., 2000; Teale \& Fanning, 2000b). A further possible example is the Rampura Agucha $\mathrm{Zn}-\mathrm{Pb}-\mathrm{Ag}$ deposit in northwest India, which is thought to have formed at $~ 1870-1800$ Ma (Hazarika et al., 2013) and occurs in the same Aravalli-Delhi Fold Belt as the Neoproterozoic Khetri $\mathrm{Cu}-\mathrm{Au}$-Fe province to the northeast (Knight et al., 2002; Li et al., 2019).

Although uranium is anomalous in some $\mathrm{Cu}-\mathrm{Au}-\mathrm{Fe}( \pm \mathrm{Co}, \mathrm{REE})$ deposits in syn-orogenic settings (e.g. Salobo deposit in Carajás province, de Melo et al., 2017; Ernest Henry, E1 and Monakoff deposits in Cloncurry province, Mark et al., 2006, Williams et al., 2015; Juno deposit in Tennant Creek province, Large, 1975), significant $\mathrm{U}$ enrichments in $\mathrm{Cu}-\mathrm{Au}$-Fe deposits in these settings are evidently quite rare. In the Mt Isa Inlier the Mary Kathleen U-REE deposit and albitite-hosted U deposits such as Valhalla occur in separate metallogenic provinces to the west of the Cloncurry $\mathrm{Cu}-\mathrm{Au}-\mathrm{Fe}( \pm \mathrm{Co}, \mathrm{REE})$ province. Available geochronology suggests that uraninite mineralisation formed at $1550 \pm 15 \mathrm{Ma}$ at Mary Kathleen (Page, 1983), and between $1555 \mathrm{Ma}$ and $1530 \mathrm{Ma}$ at the Valhalla albitite-hosted $U$ deposit (Polito et al., 2009). The younger ages of the $U$ mineralisation are within uncertainty of the older ages of the second major $\mathrm{Cu}-\mathrm{Au}$ ore-forming event at 1530-1490 Ma (Perkins and Wyborn, 1998; Goutier et al., 2001; Duncan et al., 2011). The relationship between the $\mathrm{U}$ in some of the $\mathrm{Cu}-\mathrm{Au}-\mathrm{Fe}$ deposits of the Cloncurry province and the $U$ deposits to the west in the Mount Isa Inlier remains unclear. The well-known uranium-rich mineralisation in the Gawler Craton occurs in a different, post-orogenic, setting as summarised below. 


\subsection{Post-orogenic settings}

The key example of this setting is the eastern Gawler Craton hosting the giant Olympic Dam Cu$\mathrm{U}-\mathrm{Au}$ deposit; the subjacent Curnamona Province to the east, with minor known $\mathrm{Cu}-\mathrm{Au}-\mathrm{Fe}( \pm \mathrm{Co}$, REE) deposits, shared a similar evolution around the period of $\mathrm{Cu}-\mathrm{Au}-\mathrm{Fe}$ mineralisation in the early Mesoproterozoic. Whereas the eastern Gawler Craton and Curnamona Province experienced similar early (Paleoproterozoic) histories to those of the syn-orogenic $\mathrm{Cu}-\mathrm{Au}-\mathrm{Fe}( \pm$ Co, REE) provinces (basin formation, and inversion related to major orogenic events with temporally overlapping felsic and mafic magmatism, and syn-tectonic IOCG-related hydrothermal alteration) the eastern Gawler Craton appears to have undergone a further stage of geodynamic development. This involved a switch from a broadly compressional (orogenic) to an extensional (post-orogenic) regime marked by voluminous felsic-dominated bimodal igneous activity. The major IOCG deposits such as Olympic Dam, Prominent Hill and Hillside are interpreted to have formed during this tectonic switching at $1595-1575$ Ma (Skirrow et al., 2007, 2018). Unlike the syn-orogenic settings, volcanic rocks of roughly similar age to the deposits are preserved in the post-orogenic setting of the Gawler Craton $\mathrm{Cu}-\mathrm{Au}-\mathrm{Fe}$ deposits. The magmatism is characteristically A- and/or high-temperature I-type with weakly to moderately K-rich mafic to ultramafic intrusive and volcanic rocks, and there are few igneous rocks of intermediate composition. Broadly syn-mineralisation alkaline igneous rocks appear to be more abundant in post-orogenic compared to syn-orogenic settings of $\mathrm{Cu}-\mathrm{Au}-\mathrm{Fe}( \pm \mathrm{Co}, \mathrm{REE})$ deposits. For example the ultramafic dykes at the Olympic Dam deposit (Johnson \& Cross, 1995) and picrite dykes at the Wirrda Well prospect (Huang et al., 2016) have weakly alkaline compositions.

Other deposit types in the eastern Gawler Craton and Curnamona Province that mostly formed during the same $\sim 1595-1575$ Ma period as the IOCG deposits include: small low-Fe-oxide Cu-Au deposits in the Moonta-Wallaroo district, associated with quartz veins and K-feldspar-chloritesericite alteration; low-Fe-oxide $\mathrm{Cu}-\mathrm{Mo}(-\mathrm{Au})$ stratabound mineralisation adjacent to Fe-oxiderich alteration zones (e.g. Kalkaroo and Portia deposits, Curnamona Province); Au-Mo-bearing quartz veins (e.g. White Dam deposit, Curnamona Province) and Mo-greisen type mineralisation (Moonta-Wallaroo district); Ag- and Pb-rich epithermal-like quartz vein mineralisation and shear-hosted Au-quartz vein deposits in the central Gawler Craton to the west of the IOCG Cu-AuFe metallogenic province. In addition there are numerous Fe oxide bodies of hydrothermal origin in both the eastern Gawler Craton and western Curnamona Province, as well as BIF-related Fe ore deposits that pre-date the $\mathrm{Cu}$-Au mineralisaton (e.g. Middleback Ranges, Gawler Craton). The character and possible origins of the hydrothermal Fe oxide bodies, which are largely barren of $\mathrm{Cu}-\mathrm{Au}$, are discussed in later sections. Finally, the giant Paleoproterozoic Broken Hill Pb-Zn-Ag deposit occurs in the Curnamona Province to the east of the IOCG $\mathrm{Cu}-\mathrm{Au}$-Fe metallogenic provinces of the western Curnamona Province (Olary Domain) and the Gawler Craton, not unlike the spatial and temporal relationships observed in the eastern Mt Isa Inlier where the Broken Hill-type Cannington Ag-Pb-Zn deposit occurs adjacent to (or within) the Cloncurry $\mathrm{Cu}-\mathrm{Au}-\mathrm{Fe}( \pm$ Co, REE) province.

Other possible examples of post-orogenic settings of $\mathrm{Cu}-\mathrm{Au}-\mathrm{Fe}( \pm \mathrm{Co}, \mathrm{REE})$ mineralisation include the paragenetically late stages of $\mathrm{Cu}-\mathrm{Au}-\mathrm{Bi}$ mineralisation in the Tennant Creek province which, like the IOCG mineralisation in the Gawler Craton, is characterised by brittle deformation fabrics and a dominance of hematite-rich (rather than magnetite-rich) iron oxide alteration. Examples 
include: Gecko K44 upper zone of Au-rich $\mathrm{Cu}$-Bi mineralisation, and the Au-Bi-Se-rich Eldorado deposit. Also, the $\mathrm{Cu}$ - and hematite-magnetite-bearing breccias at the Sue-Dianne deposit in the Great Bear magmatic zone may represent a post-orogenic overprint on a syn-late-orogenic metallogenic belt (see also hybrid settings, below).

\subsection{Continental margin arc (Andean type) settings}

In contrast to the Neoarchean to Neoproterozoic syn-orogenic settings, Cretaceous $\mathrm{Cu}-\mathrm{Au}-\mathrm{Fe}$ deposits in the Chilean and Peruvian Andes formed within a continental margin magmatic arc, either during extensional tectonism (Sillitoe, 2003) or as extension switched to inversion (Chen et al., 2013). Moreover, available geochronological data reviewed in the Supplementary Information indicate the Cretaceous Andean $\mathrm{Cu}-\mathrm{Au}$-Fe deposits formed up to $\sim 15$ million years prior to the onset of a major inversion event, rather than immediately following such an event as in the post-orogenic setting of the eastern Gawler Craton deposits. Host rocks in the Cretaceous Andean settings are dominated by volcanic and intrusive rocks of mainly intermediate to felsic composition, with relatively minor sedimentary or metamorphic components. The abundance of calc-alkaline intermediate compositions in this setting, and the close spatial-temporal relationships between intrusions and $\mathrm{Cu}-\mathrm{Au}-\mathrm{Fe}$ mineralisation (Sillitoe, 2003), differ from the settings of syn- and post-orogenic $\mathrm{Cu}-\mathrm{Au}-\mathrm{Fe}$ deposits. The Cretaceous Andean metallogenic provinces containing the $\mathrm{Cu}-\mathrm{Au}-\mathrm{Fe}$ deposits also host small to medium size porphyry copper and skarn, large iron oxide-apatite (IOA), and 'manto' $\mathrm{Cu}-\mathrm{Ag}$ deposits that comprise stratabound, epigenetic, Fe-oxide-poor mineralisation.

Based on the few available high-precision ages using robust geochronometers for the Cretaceous Fe and $\mathrm{Cu}$ deposits, most of the dated IOA deposits formed at 131-127 Ma along with some porphyry $\mathrm{Cu}$ deposits. Importantly, the limited available geochronology indicates that the dated IOA deposits significantly predated the major $\mathrm{Cu}-\mathrm{Au}$-Fe deposits, which formed at $\sim 122-110 \mathrm{Ma}$ (e.g. Mantoverde, Candelaria, Raúl-Condestable, early alteration at Mina Justa). The few available dates for Cretaceous manto $\mathrm{Cu}(-\mathrm{Ag})$ deposits indicate alteration at $\sim 106-101 \mathrm{Ma}$, based on $\mathrm{K}$ feldspar ${ }^{40} \mathrm{Ar}-{ }^{39} \mathrm{Ar}$ dating (e.g. El Soldado deposit, Wilson et al., 2003). However, the significance of these K-feldspar ages, along with other ${ }^{40} \mathrm{Ar}-{ }^{39} \mathrm{Ar}$ ages of $\sim 104-95 \mathrm{Ma}$ for adularia associated with copper mineralisation at the Mina Justa IOCG deposit (Chen et al., 2010a), remains unclear and they may represent cooling rather than formation ages. By comparison, at the latitudes of the Chilean Cretaceous $\mathrm{Cu}-\mathrm{Au}-\mathrm{Fe}$ deposits (e.g. $20^{\circ}-33^{\circ} \mathrm{S}$ ) the onset of inversion of the Jurassic arc and basin system hosting many of the $\mathrm{Cu}-\mathrm{Au}-\mathrm{Fe}$ deposits occurred at 107-105 Ma, with a main phase of compression at 100-95 Ma (Bascuñán et al., 2016; Fennell et al., 2019; Boyce et al., 2020).

These timing constraints indicate that the major $\mathrm{Cu}-\mathrm{Au}-\mathrm{Fe}$ deposits formed during periods of extension or transtension several m.y. (up to $\sim 15$ m.y) prior to the Cretaceous compressional tectonic event, although there may be some overlap with the initial stages of orogenesis as previously suggested by Chen et al. (2013). In conclusion, the setting and timing of the Andean $\mathrm{Cu}-\mathrm{Au}-\mathrm{Fe}$ deposits, as well as some manto $\mathrm{Cu}$ deposits, can be described as pre- to early-orogenic. 


\subsection{Possible hybrid settings}

The setting of the Paleoprotorozoic Kiruna $\mathrm{Cu}-\mathrm{Au}-\mathrm{Fe}$ province and the broader region of northern Fennoscandia has been interpreted as an evolving Andean-type continental margin magmatic arc, that was inverted in a series of orogenic events (as discussed by Lahtinen et al., 2015, 2018; see also references therein). Interestingly, like the Cretaceous Andean setting, the Kiruna metallogenic province also saw the development of large IOA deposits and probably porphyry $\mathrm{Cu}$ deposits (e.g. Aitik, Wanheinen et al., 2010) during arc-related magmatism ( 1884-1876 Ma), and later development of $\mathrm{Cu}-\mathrm{Au}-\mathrm{Fe}( \pm \mathrm{Co}, \mathrm{REE}$ ) mineralisation, commencing at $\sim 1862 \mathrm{Ma}$ (see review of geochronology, Supplementary Information and references therein). A key difference between the Kiruna and Andean $\mathrm{Cu}-\mathrm{Au}-\mathrm{Fe}$ settings is that in the Kiruna province the earliest $\mathrm{Cu}-$ $\mathrm{Au}-\mathrm{Fe}( \pm \mathrm{Co}, \mathrm{REE}$ ) deposits appear to have formed during and/or late within (rather than prior to) a major orogenic episode that post-dated arc magmatism and related IOA and porphyry $\mathrm{Cu}$ deposits. A second period of $\mathrm{Cu}-\mathrm{Au}-\mathrm{Fe}( \pm \mathrm{Co}$, REE) deposit formation at $\sim 1782-1757 \mathrm{Ma}$ also appears to have occurred during and/or late within another orogenic event affecting northern Fennoscandia (Supplementary Information). It is notable that the Kiruna province is dominated by magmatic arc-related igneous host rocks with volumetrically minor (meta)sedimentary basinal rocks, and although containing world-class IOA deposits the known $\mathrm{Cu}-\mathrm{Au}-\mathrm{Fe}( \pm \mathrm{Co}, \mathrm{REE})$ deposits are all small. Overall, the Kiruna province can be interpreted to represent a hybrid setting where an early continental margin magmatic arc setting was overprinted by multiple orogenic events, two of which also resulted in formation of syn- to late-orogenic $\mathrm{Cu}-\mathrm{Au}-\mathrm{Fe}( \pm \mathrm{Co}$, REE) deposits.

The Paleoproterozoic Great Bear magmatic zone (GBMZ) in northwestern Canada hosts well documented hydrothermal alteration and diverse types of mineralisation $\mathrm{C} \mathrm{Cu}, \mathrm{Au}, \mathrm{U}, \mathrm{Co}, \mathrm{Mo}, \mathrm{V}$, etc) including small $\mathrm{Au}, \mathrm{Cu}$ and $\mathrm{U}$ resources (Mumin et al., 2007, 2010; Corriveau et al., 2010, 2016; Montreuil et al., 2016). Like the Andean and Kiruna settings described above, igneous rocks of the GBMZ are interpreted to have formed in a continental margin magmatic arc setting (Hildebrand et al., 1987; Ootes et al., 2017). Arc magmatism, initiated at 1876 Ma, was preceded by the short-lived Calderian orogeny. Rather than fully postdating the Calderian orogeny, as previously thought, early phases of the GBMZ magmatism ( 1876-1873 Ma) are now interpreted as syn-deformational within a transpressional regime late within the Calderian orogeny, and exhibit 'syn-collisional' and 'volcanic arc' calc-alkaline geochemical signatures (Montreuil et al., 2016; Ootes et al., 2017). The later magmatic phases ( 1869-1866 Ma) have compositions indicating a transition from collisional to a post-collisional and extensional setting (Montreuil et al., 2016; Ootes et al., 2017). The overall setting therefore appears to be one where syn-orogenic magmatism was overprinted by magmas with continental arc-like character yet in an extensional, post-orogenic, setting. Accordingly, the GBMZ may share features (and represent a hybrid?) of both the syn-late-post-orogenic type settings and the Andean type continental margin magmatic arc setting of $\mathrm{Cu}-\mathrm{Au}-\mathrm{Fe}$ provinces globally. 


\subsection{Synthesis: tectonic settings and geodynamic evolution of $\mathrm{Cu}-\mathrm{Au}-\mathrm{Fe}$ ( \pm Co, REE) provinces}

Figure 3 illustrates the three proposed tectonic settings of different types of $\mathrm{Cu}-\mathrm{Au}-\mathrm{Fe}( \pm \mathrm{Co}, \mathrm{REE})$ deposits and their host provinces. The upper panel shows the setting of arc-hosted Andean-type $\mathrm{Cu}-\mathrm{Au}-\mathrm{Fe}$ deposits within a continental margin magmatic arc that is undergoing extension. The rifting arc and retro-back-arc basinal environments host not only the $\mathrm{Cu}-\mathrm{Au}$-Fe deposits but also (earlier) IOA, small porphyry $\mathrm{Cu}$, skarn-related and (coeval to later?) 'manto' $\mathrm{Cu}$ deposits. This panel also shows subduction-related metasomatism of mantle lithosphere along a continental margin or root of a lithospheric block. A basin system is illustrated at the right side where the continental margin has undergone extension and thinning. This lithospheric and basin architecture is based partly on the Gawler Craton - Curnamona Province (Skirrow et al., 2018) but is herein proposed to be more generally applicable to the settings of other syn- and postorogenic $\mathrm{Cu}-\mathrm{Au}-\mathrm{Fe}( \pm \mathrm{Co}, \mathrm{REE})$ deposits.

The middle panel of Figure 3 illustrates basin inversion during an orogenic event, triggered for example by oceanic plateau, island arc or microcontinent collision at a plate margin relatively distal from the basin setting. Crucially for $\mathrm{Cu}-\mathrm{Au}-\mathrm{Fe}( \pm \mathrm{Co}, \mathrm{REE})$ deposit formation, melting of lithospheric mantle and then crustal melting occur during and late within the orogenic event due to the combination of prior metasomatism of lithospheric mantle and gravitational instabilities at the LAB triggered by the collisional processes. The juxtaposition of this mantle-derived magmatism with a pre-existing basin at an extended continental margin is the key setting for the formation of syn-orogenic $\mathrm{Cu}-\mathrm{Au}-\mathrm{Fe}( \pm \mathrm{Co}, \mathrm{REE})$ deposits. These syn-deformational deposits form at generally mesothermal conditions within basinal \pm igneous host rocks.

The lower panel (Fig. 3) shows how in some cases the orogenic setting evolves from a compressional to an extensional tectonic regime. This may be driven by further thinning of the mantle lithosphere, for example via wholesale removal or foundering of large parts of the lithospheric mantle (Skirrow et al., 2018) or by slab rollback if subduction was still active (Tiddy \& Giles, 2020). This is the setting of the post-orogenic $\mathrm{Cu}-\mathrm{Au}-\mathrm{Fe}( \pm \mathrm{Co}, \mathrm{REE})$ deposits such as those of the eastern Gawler Craton, and where earlier mesothermal, exhumed, syn-orogenic deposits and alteration may be overprinted by post-orogenic mineralisation in shallow-crustal subvolcanic to volcanic settings. 

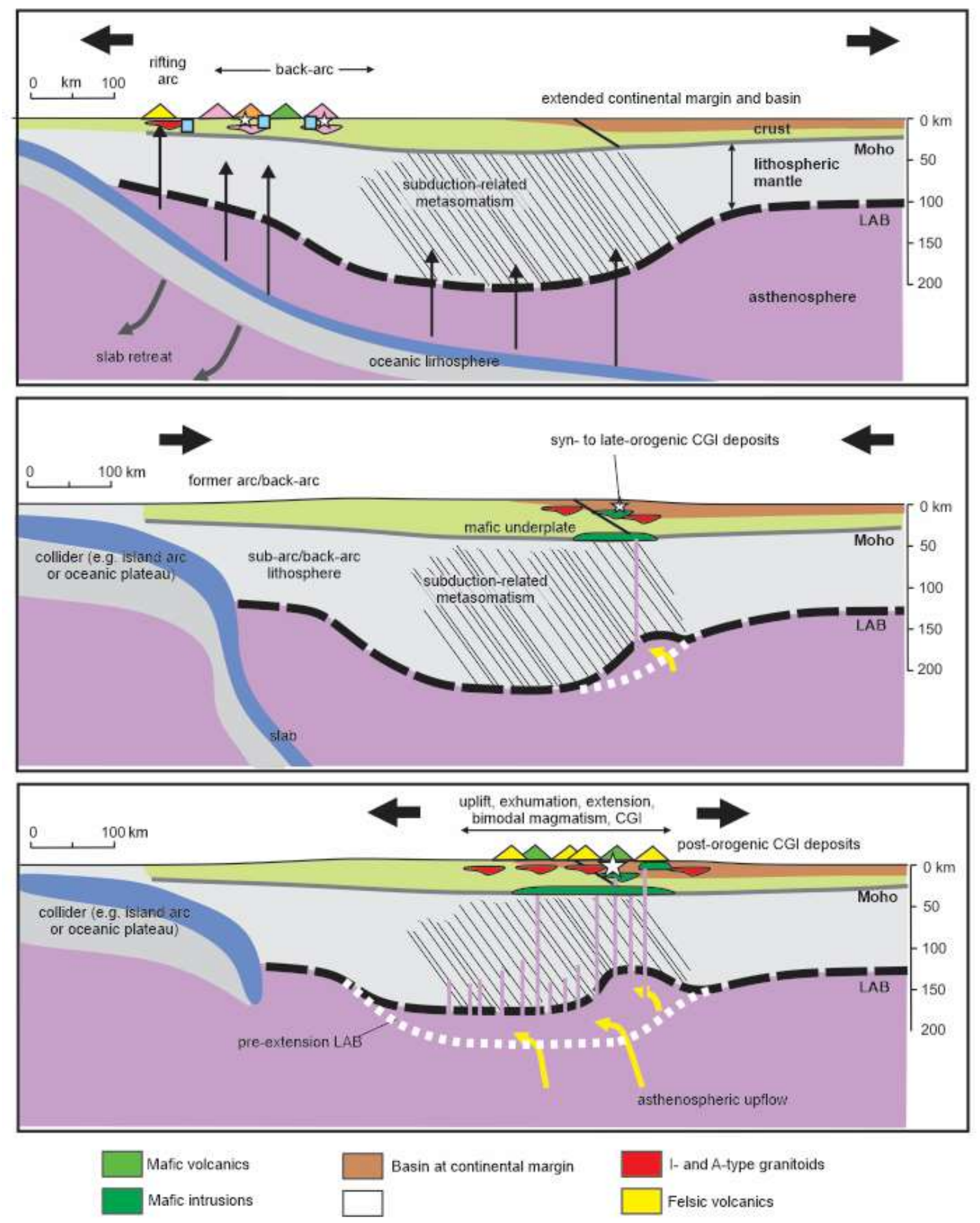

Figure 3. Schematic tectonic settings and geodynamic evolution of arc-hosted $\mathrm{Cu}-\mathrm{Au}-\mathrm{Fe}$ and IOA deposits (top panel), syn-orogenic $\mathrm{Cu}-\mathrm{Au}-\mathrm{Fe}( \pm \mathrm{Co}, \mathrm{REE})$ deposits (middle panel), and post-orogenic $\mathrm{Cu}-\mathrm{Au}-\mathrm{Fe}( \pm \mathrm{Co}$, REE) deposits (see text). Mineral deposit symbols - stars: $\mathrm{Cu}-\mathrm{Au}-\mathrm{Fe}( \pm \mathrm{Co}, \mathrm{REE})$ or CGI deposits, squares: IOA deposits. 


\section{Hydrothermal alteration and mineralisation}

Hydrothermal minerals in $\mathrm{Cu}-\mathrm{Au}-\mathrm{Fe}( \pm \mathrm{Co}, \mathrm{REE})$ deposits occur within assemblages that show a characteristic sequence through time, commonly known as a paragenetic sequence. The general features of such sequences in $\mathrm{Cu}-\mathrm{Au}-\mathrm{Fe}( \pm \mathrm{Co}, \mathrm{REE})$ deposits of different types have been known for some time (since Hitzman et al., 1992), yet the broader context of such hydrothermal mineral formation has not been well understood in terms of links with geotectonic settings or origins of the hydrothermal fluids. A review of published paragenetic sequences of 29 representative deposits in 9 provinces, summarised in Figure 4, provides a framework for comparison with other deposit types and for discussion of the origins of the hydrothermal minerals. The next section focuses on hydrothermal alteration and mineralisation assemblages proximal to the deposits, and then the hydrothermal assemblages are compared with other deposit types, before a brief description of regional-scale alteration. The chemical/metasomatic descriptors (e.g. Na-Ca, Ca$\mathrm{Fe}, \mathrm{Fe}-\mathrm{K}$ ) generally correspond to the types previously described by Hitzman et al. (1992), Corriveau et al. $(2010,2016)$ and Barton (2013).

\subsection{Proximal mineral assemblages and paragenetic sequences}

The mineral assemblages in $\mathrm{Cu}-\mathrm{Au}-\mathrm{Fe}( \pm \mathrm{Co}, \mathrm{REE})$ including IOCG deposits can be represented by their dominant chemical composition, which change systematically through paragenetic time at a given location. Although there is an influence on mineralogy by the local host rock compositions, which are highly variable in each province, the remarkably consistent mineralogy of the hydrothermal assemblages and their sequences suggests that the hydrothermal assemblages dominantly reflect the physico-chemical characteristics of the hydrothermal fluids. This is particularly the case in the most intensely altered proximal/central parts of deposits, where it can be assumed that fluid/rock ratios were higher than in peripheral zones. The approach taken here is to identify assemblages of hydrothermal minerals that formed at broadly the same time and therefore represent possible equilibrium chemical conditions or an approach to equilibrium. This equilibrium mineral assemblage concept is similar to that used in metamorphic petrology. Accordingly, the focus is on the presence or absence of particular minerals during a particular paragenetic stage rather than on their relative abundance, although the amounts of the dominant minerals are taken into account in assigning an assemblage to particular chemical groupings and stages (i.e. Na, Na-Ca, Ca-Fe, K-Fe, etc). Published paragenetic sequences have been critically assessed and minerals assigned to stages and chemical groupings shown in Figure 4. In some cases the reported mineral assemblages do not fit neatly within the generalised sequence in Figure 4, in which cases they may be shown between stages (e.g. an assemblage with Ca-rich as well as Fe-K-rich minerals is plotted between stage $2 \mathrm{Ca}-\mathrm{Fe}$ and stage $3 \mathrm{Fe}-\mathrm{K}$ assemblages). 

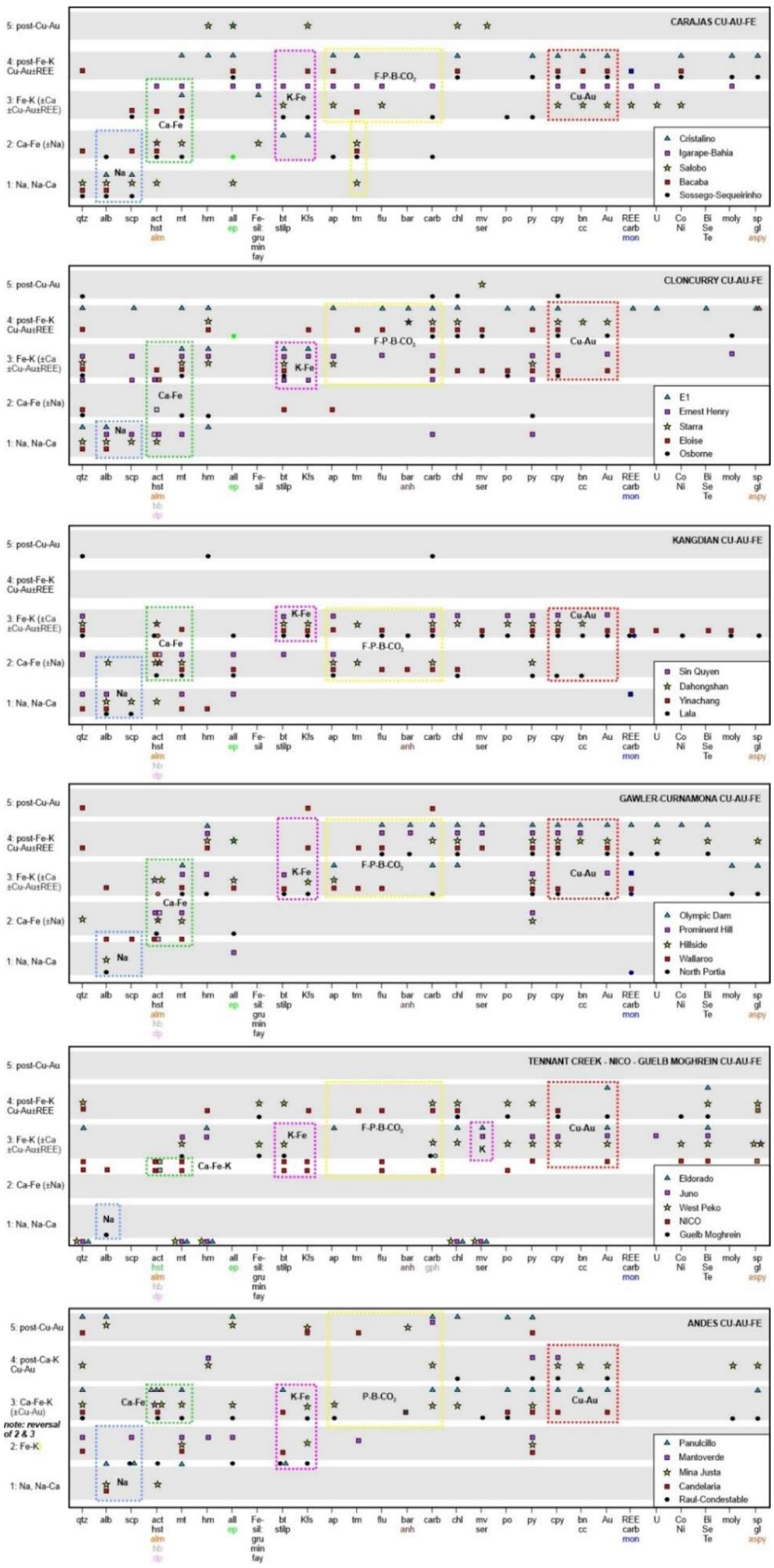
Figure 4. Paragenetic sequences of hydrothermal minerals for major and representative deposits in selected $\mathrm{Cu}-\mathrm{Au}-\mathrm{Fe}( \pm \mathrm{Co}, \mathrm{REE})$ provinces. References are listed in Appendix 1. Mineral abbreviations: alb albite, act - actinolite, all - allanite, alm - almandine, anh - anhydrite, ap - apatite, aspy - arsenopyrite, Au - gold, bar - barite, bn - bornite, Bi - bismuth sulfides and/or native Bi, bt - biotite, carb - carbonate, cc chalcocite, chl - chlorite, Co - cobalt-rich sulfides, cpy - chalcopyrite, dp - diopside, ep - epidote, fay fayalite, Fe-sil - Fe-Mg-rich silicates (e.g. fayalite, greenalite, grunerite, minnesotaite), flu - fluorite, gl galena, gru - grunerite, hb - hornblende, hm - hematite, hst - hastingsite, Kfs - K-feldspar, mon - monazite, min - minnesotaite, moly - molybdenite, mt - magnetite, mv - muscovite, $\mathrm{Ni}$ - nickel-rich sulfides, po pyrrhotite, py - pyrite, qtz - quartz, REE - REE-rich minerals (carbonate-rich and/or P-rich including monazite and alumino-phosphate-sulfide REE minerals), scp - scapolite, Se - selenium-rich minerals, ser sericite, sp - sphalerite, stilp - stilpnomelane, Te - tellurium-rich minerals, tm - tourmaline, U - uraniumrich minerals (e.g. uraninite/pitchblende).

\subsubsection{Alteration-mineralisation stages}

The texturally earliest assemblages are almost invariably of sodic character, with or without calcic minerals ( $\mathrm{Na}$, Na-Ca in Fig. 4) in deposits from all three of the geotectonic settings described above. Exceptions include the Tennant Creek province where no $\mathrm{Na}$ or $\mathrm{Na}-\mathrm{Ca}$ alteration is evident at the deposits, although $\mathrm{Na}$ and $\mathrm{K}$ alteration of regional igneous rocks has been documented in whole-rock geochemical data, albeit without isotopic age constraints (Donnellan et al., 1995). The $\mathrm{Na}$ and Na-Ca alteration is represented mainly by albitisation \pm scapolitic alteration \pm Caamphibole (e.g. actinolite) alteration, which are less commonly accompanied by diopside or magnetite or allanite.

In the syn- and post-orogenic settings (all provinces in Fig. 4 except Andes) the $\mathrm{Na}$ and $\mathrm{Na}-\mathrm{Ca}$ alteration transitions to assemblages of Ca-Fe-rich hydrothermal minerals, in some cases with continued formation of sodic minerals. The Ca-Fe assemblages (stage 2 in Fig. 4) are dominated by Fe oxides (generally magnetite) and Ca-amphiboles such as actinolite or hastingsite, and less commonly contain Ca-Fe-rich garnet such as almandine. A few deposits also contain Fe-silicates such as grunerite, minnesotaite, or fayalitic olivine that formed during the Ca-Fe stage (e.g. Salobo, Carajás province; Guelb Moghrein; West Peko, Tennant Creek province). Additionally, skarn-like $\mathrm{Ca}-\mathrm{Fe}$ alteration is prominent in some orogenic-related $\mathrm{Cu}-\mathrm{Au}-\mathrm{Fe}( \pm \mathrm{Co}, \mathrm{REE})$ deposits, and is typically dominated by clinopyroxene or amphibole \pm garnet (generally minor), with or without magnetite, scapolite and apatite. The early anhydrous skarn-like alteration is almost invariably barren of coeval $\mathrm{Cu}-\mathrm{Au}$ mineralisation but may be overprinted by $\mathrm{Cu}-\mathrm{Au}$. Examples in the eastern Gawler Craton include: the Hillside deposit where early prograde magnetite-garnet skarn was overprinted by clinopyroxene-actinolite-biotite-allanite-K-feldspar and thence by hematite-chalcopyrite-chlorite-bornite-chalcocite with rare $\mathrm{Bi}, \mathrm{U}$ and $\mathrm{Pb}$ minerals (Conor et al., 2010). A key example in the Cloncurry province is the Mt Elliott/SWAN deposit where early diopside-scapolite was overprinted by amphibole-calcite-chalcopyrite-scapolite \pm magnetite, andradite, tourmaline, allanite, apatite, pyrite and pyrrhotite (Wang \& Williams, 2001; Brown \& Porter, 2010). Anhydrite and fluorite also have been reported from the Mt Elliott-SWAN system, which is hosted by metamorphic calcsilicate, meta-siliciclastic (including graphitic) and metamafic/intermediate igneous rocks that were Na-altered prior to skarn alteration (Brown \& Porter, 2010). 
The appearance of K-rich minerals marks an important chemical transition in the hydrothermal evolution, represented by K-feldspar, biotite or white mica. This K-metasomatism may commence during the Ca-Fe alteration stage or form a discrete and later Fe-K stage (stage 3 in Fig. 4) with assemblages such as magnetite-biotite or magnetite-K-feldspar. Crucially the first appearance of $\mathrm{Cu}$ sulfide and $\mathrm{Au}$ mineralisation generally overlaps with the Fe-K alteration stage, which may continue with some calcic mineral formation in a few cases. Interestingly, the available evidence for the Andean $\mathrm{Cu}-\mathrm{Au}-\mathrm{Fe}( \pm \mathrm{Co}, \mathrm{REE}$ ) deposits shows a possible reversal of the $\mathrm{Fe}-\mathrm{K}$ and $\mathrm{Ca}-\mathrm{Fe}$ stages in comparison with the orogenic-related deposits, such that the main $\mathrm{Cu}$ mineralisation appears with the paragenetically later Ca-Fe alteration in some Andean cases (e.g. with amphibole at Candelaria and Panulcillo; Fig. 4).

A key finding from the review of paragenetic sequences is that $\mathrm{Cu}-\mathrm{Au}$ mineralisation is in every province accompanied by the appearance of volatile-rich minerals such as fluorite $(\mathrm{F})$, apatite $(\mathrm{P})$, carbonate $\left(\mathrm{CO}_{2}\right)$, tourmaline (B), and/or sulfates (S). The amounts and combinations of such minerals accompanying $\mathrm{Cu}-\mathrm{Au}$ mineralisation are highly variable between and even within deposits, and yet the close temporal and textural association is apparent in all of the syn- and post-orogenic provinces. By comparison, $\mathrm{Cu}$-Au mineralisation in the Andean deposits appears to be less endowed with fluorite, apatite, carbonate, tourmaline or sulfates. The volatile-rich assemblages with $\mathrm{Cu}-\mathrm{Au}$ mineralisation occur both during stage $3 \mathrm{Fe}-\mathrm{K}$ alteration and also in some deposits post-dating stage 3 , accompanied by chlorite, sericite and hematite (stage 4 in Fig. 4).

The hematite-sericite-chlorite-carbonate assemblage is by far the most important $\mathrm{Cu}-\mathrm{Au}-\mathrm{U}$-REErelated hydrothermal assemblage in the post-orogenic setting of the Gawler Craton IOCG deposits. In this province only very minor $\mathrm{Cu}$-Au mineralisation occurs with earlier $\mathrm{Fe}-\mathrm{K}$ or $\mathrm{Ca}-\mathrm{Fe}$ alteration. These stage 4 assemblages (hematite-sericite-chlorite-carbonate) are also present in many syn-late-orogenic provinces in addition to stage $3 \mathrm{Cu}-\mathrm{Au}$ (Carajás, Cloncurry, Guelb Moghrein, Great Bear magmatic zone, Andean), but are generally much less well developed than in the Gawler Craton. Examples include: Cristalino (with chalcopyrite) and Salobo (postchalcopyrite) in the Carajás province; Starra, E1 and Eloise (all with chalcopyrite) in the Cloncurry province; Gecko K44 (with chalcopyrite) in the Tennant Creek province; and NICO (with chalcopyrite) in the GBMZ. The hematite-sericite-chlorite-carbonate assemblage is evidently lacking in the Kangdian province and at Guelb Moghrein.

\subsubsection{Iron oxide and $\mathrm{Fe}$ - and $\mathrm{Cu}$-sulfide paragenetic relationships}

The compilation of paragenetic sequences in Figure 4 shows temporal relationships between the Fe oxides, Fe sulfides and $\mathrm{Cu}(-\mathrm{Fe})$ sulfides, which vary systematically between deposits and provinces. These assemblages provide important constraints on the chemical and physical parameters during hydrothermal activity, such as oxidation-reduction conditions, $\mathrm{pH}$, sulfur contents of fluids and temperature, as discussed later in this contribution and in the accompanying paper. Most deposits in the syn-late orogenic provinces (Carajás, Cloncurry, Kangdian, Tennant Creek, Guelb Moghrein) tend to be dominated by magnetite-rich hydrothermal assemblages with pyrite and chalcopyrite, and with pyrrhotite in some deposits in most syn-late-orogenic provinces and much less common hypogene bornite \pm chalcocite. In the Carajás province bornite \pm chalcocite appear to have been contemporaneous with chalcopyrite and Fe- and/or K-silicate assemblages, and mostly post-date magnetite; only at Cristalino is the reported bornite \pm chalcocite associated with late-stage hematite. In the Cloncurry province 
hypogene bornite and chalcocite are rarely reported in the magnetite-pyrite \pm pyrrhotite dominated deposits, with Starra the main example where bornite and chalcocite occur in a latestage (post-magnetite) assemblage with hematite, $\mathrm{Au}$, chalcopyrite, barite, chlorite and carbonate. Similarly, the magnetite-pyrite \pm pyrrhotite dominated deposits in the Tennant Creek province and at Guelb Moghrein do not have hypogene bornite or chalcocite, nor do hematite-rich chalcopyrite-Au-Bi or Au-Bi-only deposits in Tennant Creek (e.g. Gecko K44, Eldorado). In the Kangdian province the chalcopyrite-bornite \pm chalcocite assemblages are reported as coeval with pyrite \pm pyrrhotite and Fe- and/or K-silicates, and generally post-dated magnetite, much the same as in the Carajás province.

Conversely, IOCG deposits in the key example of a post-orogenic province, the Gawler Craton, are dominated by hematite, pyrite, chalcopyrite, bornite and chalcocite, and contain no or trace pyrrhotite and only minor magnetite which is restricted to generally less $\mathrm{Cu}$-Au mineralised deeper and/or peripheral parts of the deposits (Fig. 4; Fairclough, 2005; Belperio et al., 2007; Porter, 2010a; Ehrig et al., 2012; Schlegel \& Heinrich, 2015). At Olympic Dam the magnetite commonly occurs with siderite and locally abundant apatite, and there is evidence for replacement of magnetite by hematite (Reeve et al., 1990; Haynes et al., 1995; Ehrig et al., 2012).

Oxide-sulfide assemblages in the Andean $\mathrm{Cu}-\mathrm{Au}-\mathrm{Fe}$ deposits vary from pyrrhotite-bearing to hematite-bearing in the presence of magnetite. For example, early magnetite-pyrite-biotite at Candelaria was succeeded by pyrite-pyrrhotite-chalcopyrite-actinolite, and similarly at RaúlCondestable early magnetite-biotite was overprinted by chalcopyrite-pyrite-pyrrhotiteamphibole. No significant late-stage hematite has been reported at Candelaria or RaúlCondestable. This contrasts with Mantoverde where chalcopyrite is associated with pyritehematite deposition which, according to Rieger et al. (2010), occurred before magnetite (unusual for $\mathrm{Cu}-\mathrm{Au}-\mathrm{Fe}$ ( $\pm \mathrm{Co}, \mathrm{REE}$ ) deposits) or after magnetite (Benavides et al., 2007; as shown in Fig. 4). The late-stage hematite-chalcopyrite-carbonate at Mina Justa also resembles the paragenetic sequence at Mantoverde.

\subsubsection{Uranium and REE mineral parageneses}

The occurrence of REE- and U-bearing minerals varies fairly systematically between provinces, settings and deposit parageneses. The main REE-rich phases reported in the literature are allanite, REE-carbonates and monazite, whereas uraninite is the main reported U-rich phase. Certain groups of deposits and provinces have no reported or trace REE or U minerals, including many of the pyrrhotite-bearing deposits, most of the Andean deposits (although Mantoverde has anomalous REE, Rieger et al., 2010), and most $\mathrm{Au}-\mathrm{Cu}$-Bi deposits in the Tennant Creek province. A sub-group of deposits with magnetite-pyrite-chalcopyrite contain allanite at various stages in the paragenetic sequences from pre- $\mathrm{Cu}-\mathrm{Au}$ to syn- $\mathrm{Cu}-\mathrm{Au}$ mineralisation, commonly with apatite and/or fluorite and/or carbonate. Where allanite-bearing deposits contain significant hematite, this oxide is almost always late in the paragenetic sequence and post-dates the allanite which appears to be more closely associated with earlier magnetite and Ca-mineral formation (e.g. Gawler Craton and Curnamona deposits). Like allanite, the REE-carbonates are generally associated with apatite and/or fluorite and/or carbonate assemblages with $\mathrm{Cu}-\mathrm{Au}$ mineralisation, but unlike allanite they are also associated with uraninite and do not tend to occur in pre-Cu-Au assemblages. The most important resources of REE in IOCG deposits, at the Olympic Dam deposit, are REE-carbonates associated with the hematite-pyrite-chalcopyrite-bornite-chalcocite 
assemblages that also contain volatile-rich phases such as fluorite, carbonate and barite (Ehrig et al., 2012).

\subsection{Comparison of hydrothermal assemblages in $\mathrm{Cu}-\mathrm{Au}-\mathrm{Fe}( \pm \mathrm{Co}, \mathrm{REE})$ and other deposit types}

Generalised sequences of hydrothermal mineral assemblages and major-element geochemical character for syn- and post-orogenic $\mathrm{Cu}-\mathrm{Au}-\mathrm{Fe}( \pm \mathrm{Co}, \mathrm{REE})$ deposits are compared in Figure 5 with those for Andean-type magmatic arc-hosted $\mathrm{Cu}-\mathrm{Au}-\mathrm{Fe}$ and selected other $\mathrm{Fe}$ and $\mathrm{Cu}(-\mathrm{Au})$ deposit types. First, as noted above, the relative timing of $\mathrm{K}-\mathrm{Fe}$ and $\mathrm{Ca}-\mathrm{Fe}$ assemblages are probably reversed in syn-late-post-orogenic versus Andean-type $\mathrm{Cu}-\mathrm{Au}-\mathrm{Fe}$ deposits, and the relative abundances of volatile-rich minerals accompanying $\mathrm{Cu}-\mathrm{Au}$ mineralisation are evidently greater in the orogenic-related than in the Andean-type arc-hosted deposits, based on available paragenetic data.

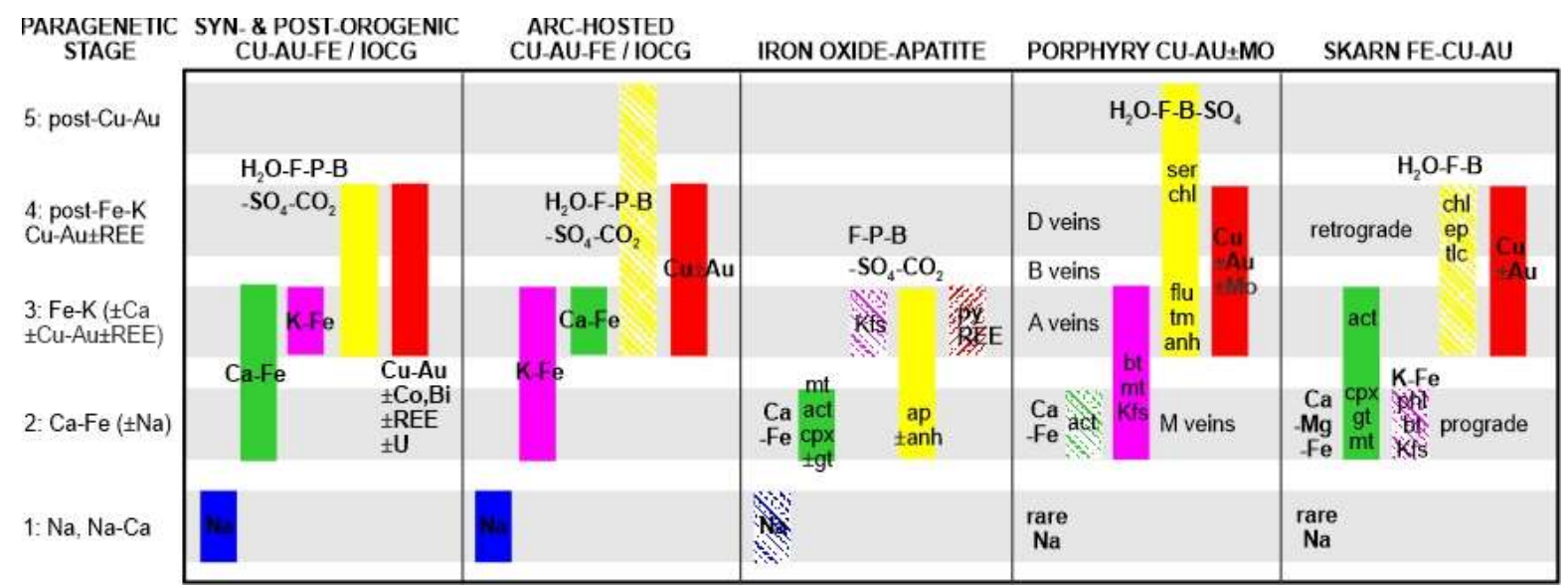

Figure 5. Generalised paragenetic sequences of hydrothermal mineral assemblages and their chemical character for syn- and post-orogenic $\mathrm{Cu}-\mathrm{Au}-\mathrm{Fe}( \pm \mathrm{Co}$, REE) including IOCG deposits, compared with archosted $\mathrm{Cu}-\mathrm{Au}-\mathrm{Fe}$, IOA, porphyry $\mathrm{Cu}-\mathrm{Au}-\mathrm{Mo}$ and skarn $\mathrm{Fe}-\mathrm{Cu}-\mathrm{Au}$ deposits. Hatchured boxes represent weakly developed assemblages compared with full-coloured boxes. Sources: syn- and post-orogenic and arc-hosted Cu-Au-Fe deposits: this study (Fig. 4); iron oxide-apatite deposits: Oyarzun et al. (2003), Li et al. (2015), Yu et al. (2015), Day et al. (2016), Tornos et al. (2016), Rojas et al. (2018), Bonyadi \& Sadeghi (2020); porphyry Cu-Au Mo deposits: Sillitoe (2010); skarn Fe-Cu-Au deposits: Meinert et al. (2005).

Second, and with few exceptions, $\mathrm{Cu}-\mathrm{Au}-\mathrm{Fe}( \pm \mathrm{Co}$, REE) deposits in all settings contain well developed early stages of $\mathrm{Na}$ and/or $\mathrm{Na}-\mathrm{Ca}$ alteration, whereas such alteration is rare and poorly developed in porphyry $\mathrm{Cu}$ and skarn $\mathrm{Fe} / \mathrm{Cu} / \mathrm{Au}$ deposits. Within proximal alteration zones at IOA deposits Na-rich alteration is generally not well developed. Interestingly, those IOA provinces with well developed and intense sodic alteration at the regional scale also contain IOCG deposits (e.g., Kiruna, Andes). In contrast, IOA provinces with poorly developed sodic alteration at any scale contain few if any significant $\mathrm{Cu}$-Au deposits of IOCG type, although some contain porphyry $\mathrm{Cu}(-\mathrm{Au})$ and skarn Fe and $\mathrm{Cu}(-\mathrm{Au})$ deposits (e.g. Middle-Lower Yangtze Belt (MLYB), China; Bafq region, Iran; southeast Missouri, USA). 
Third, Ca-Fe alteration is well developed as an early stage in many orogenic-related IOCG, IOA and skarn $\mathrm{Fe} / \mathrm{Cu} / \mathrm{Au}$ deposits but the accompanying mineral assemblages differ in each deposit type. In IOA deposits the magnetite-actinolite \pm clinopyroxene \pm garnet $\mathrm{Ca}-\mathrm{Fe}$ assemblages are generally accompanied by prominent apatite and minor pyrite, and also by anhydrite in some provinces (e.g. MLYB). In contrast, apatite is not a common mineral in early assemblages ( $\mathrm{Na}$, Na$\mathrm{Ca}, \mathrm{Ca}-\mathrm{Fe}$ ) in orogenic-related and Andean-type IOCG deposits but forms part of later volatile-rich assemblages accompanying $\mathrm{Cu}-\mathrm{Au}$ mineralisation. There are nevertheless examples where apatite is locally abundant with magnetite in early alteration at IOCG deposits, including the Sequeirinho orebody (Carajás province, Monteiro et al., 2008), deep parts of the Olympic Dam deposit (Ehrig et al., 2012; Apukhtina et al., 2017), the Acropolis and other magnetite-rich prospects near Olympic Dam (Bastrakov et al., 2007; Krneta et al., 2017; McPhie et al., 2020), and some magnetite-rich zones in deposits in the Kangdian province (e.g. Dahongshan deposit, Zhao et al., 2017. In the Olympic Dam district many of the sub-economic prospects with magnetite-rich and apatite-bearing alteration have assemblages including pyrite, carbonate, quartz, amphibole and K-feldspar (Bastrakov et al., 2007). Although apparently lacking amphibole, the apatitebearing magnetite-rich veins at the Acropolis and Wirrda Well prospects are otherwise similar to those of the aforementioned occurrences, and contain variable amounts of hydrothermal Kfeldspar, siderite, quartz, pyrite and biotite/phlogopite (Oreskes \& Einaudi, 1992; Cross, 1993) as well as paragenetically later chalcopyrite, barite, fluorite, chlorite and sericite (Krneta et al., 2017). These magnetite-rich assemblages in the Olympic Dam district differ from the typically carbonate- and K-feldspar-biotite-poor hydrothermal assemblages in most IOA deposits. Moreover, geochronological, stable and radiogenic isotope and fluid inclusion data may indicate different timing and origins of apatite-bearing magnetite alteration in IOCG hydrothermal systems of the Gawler Craton compared to IOA deposits, as discussed further below and in the accompanying paper (Skirrow, in prep.).

Magmatic-hydrothermal skarn $\mathrm{Fe}$ and $\mathrm{Cu}$ deposits developed in carbonate-bearing host rocks generally contain garnet-rich as well as clinopyroxene- and amphibole-rich zones, whereas garnet is not abundant in most orogenic-related and Andean-type IOCG deposits. Exceptions include several of the IOCG deposits in the Kangdian province where carbonate-rich host rocks are more abundant than in many other $\mathrm{Cu}-\mathrm{Au}-\mathrm{Fe}( \pm \mathrm{Co}, \mathrm{REE})$ provinces (e.g. Dahongshan deposit, Zhao et al., 2017), and a few other orogenic-related deposits (e.g. Hillside, Gawler Craton, Conor et al., 2010). Moreover, one of the distinctive features of hydrothermal assemblages in IOCG deposits including those with skarn-like alteration is the generally poor development of Mg-rich alteration relative to $\mathrm{Na}, \mathrm{Ca}, \mathrm{Fe}$ and $\mathrm{K}$ alteration, whereas in carbonate-replacement skarn deposits Mg-rich minerals may be common, such as Mg-bearing clinopyroxenes, tremolitic amphibole, phlogopite, Mg-chlorite and talc (Meinert et al., 2005). Further differences between the orogenic-related $\mathrm{Cu}-\mathrm{Au}-\mathrm{Fe}( \pm \mathrm{Co}, \mathrm{REE})$ deposits and classic magmatic-hydrothermal skarn $\mathrm{Fe}$ and $\mathrm{Cu}-\mathrm{Au}$ deposits are the enrichments in REE in some but not all of the former compared to the low REE contents of skarn deposits, and also the abundances of some of the volatile-rich phases. In particular the abundances of apatite, fluorite and barite appear to be higher in orogenic-related $\mathrm{Cu}-\mathrm{Au}-\mathrm{Fe}( \pm \mathrm{Co}, \mathrm{REE})$ deposits than in skarn deposits.

Whereas many aspects of the paragenetic sequences of orogenic-related and Andean-type archosted deposits and porphyry $\mathrm{Cu}-\mathrm{Au}$ deposits are superficially similar there are several important aspects of the geology and mineralogy that distinguish particularly the syn-orogenic $\mathrm{Cu}-\mathrm{Au}-\mathrm{Fe}( \pm \mathrm{Co}, \mathrm{REE})$ deposits from porphyry deposits. First, the crustal settings of syn-orogenic 
deposit formation at depths where brittle-ductile deformation is characteristic are significantly deeper than the subvolcanic settings of most porphyry deposits. Second, the spatial association of $\mathrm{Cu}-\mathrm{Au}$ mineralisation with coeval igneous intrusions is much weaker for the syn-orogenic (and post-orogenic) deposits compared to the obvious close relationships in porphyry systems (as noted by Williams et al., 2005 and Barton, 2013 although using different classifications of $\mathrm{Cu}-\mathrm{Au}$ Fe ( \pm Co, REE) deposits). Third, hydrothermal quartz is a major and almost ubiquitous phase in most porphyry $\mathrm{Cu}-\mathrm{Au}$ deposits whereas it is remarkably low in abundance in the most intensely altered and mineralised zones of most syn- and post-orogenic iron oxide-rich $\mathrm{Cu}-\mathrm{Au}-\mathrm{Fe}( \pm \mathrm{Co}$, REE) deposits. However, syn-orogenic $\mathrm{Cu}-\mathrm{Au}$ deposits with little or no Fe oxide commonly contain hydrothermal vein quartz.

Fourth, there are differences in the extent and intensity of Na alteration as noted above, as well as differences in REE, $\mathrm{U}, \mathrm{Co}, \mathrm{Ni}$ and other minor-element abundances that will be explored further in subsequent sections. On the other hand, there appear to be many similarities between Andeantype $\mathrm{Cu}-\mathrm{Au}-\mathrm{Fe}$ and porphyry deposits in terms of hydrothermal mineral sequences, spatial relationships to coeval intrusions, and geochemistry. The key differences are the lesser development of $\mathrm{Na}$ alteration, higher abundance of quartz but lower magnetite, and possibly lower abundances of hydrothermal carbonate and apatite in porphyry compared to Andean-type $\mathrm{Cu}-\mathrm{Au}-\mathrm{Fe}$ deposits. Associated intrusions also may be somewhat more mafic at Andean-type $\mathrm{Cu}-$ $\mathrm{Au}-\mathrm{Fe}$ deposits than at porphyry deposits (Sillitoe, 2003; Richards et al., 2017).

\subsection{Alteration zoning - deposit scale}

The sequences of hydrothermal mineral assemblages described above in $\mathrm{Cu}-\mathrm{Au}-\mathrm{Fe}( \pm \mathrm{Co}, \mathrm{REE})$ deposits produce distinctive spatial patterns of alteration-mineralisation zoning which are partly controlled by the structural settings. Based on $>30$ deposits in 10 metallogenic province these zoning patterns have been generalised for each of the three lithostratigraphic-tectonic settings, as illustrated in Figures 6A, 6B and 6C.

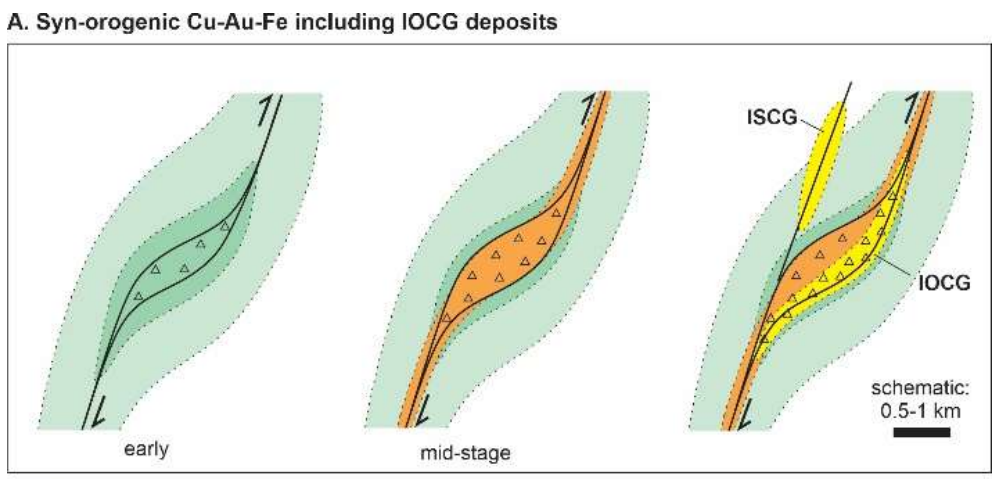

$\Delta$ breccia/shear zone: Cu-Au with Fe-K alteration \& volatiles \pm Fe-sulfides (e.g. mag-bt-py-ap-carb) breccia/shear zone: $\mathrm{Ca}-\mathrm{Fe} \pm \mathrm{Na} \pm \mathrm{K}$ alteration $\pm \mathrm{Fe}$-sulfides (e.g. mag-act-po)

breccia/shear zone: $\mathrm{Na}-\mathrm{Ca}$ alteration (e.g. alb-act-scp)

pervasive and vein: $\mathrm{Na}$ alteration (e.g. alb)

host rock - metasedimentary and/or meta-igneous 
B, Post-orogenic Cu-Au-Fe including IOCG deposits

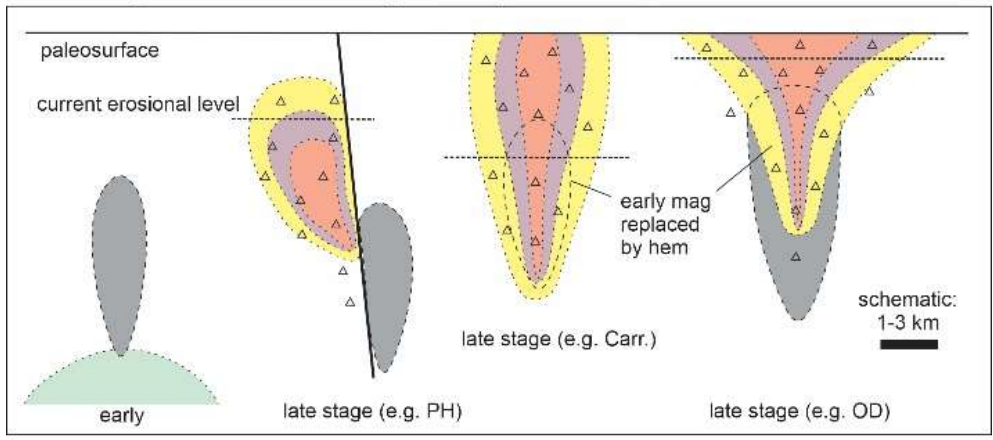

breccia: hematite-quartz $\pm U \pm \mathrm{LREE} \pm \mathrm{Au}$

breccia: hematite-sericite-bornite-chalcocite $\pm U \pm \mathrm{LREE} \pm \mathrm{Au} \pm$ carbonate \pm chlorite

breccia: hematite-sericite-chalcopyrite-pyrite $\pm U \pm \mathrm{LREE} \pm \mathrm{Au} \pm$ carbonate \pm chlorite

early mid-level magnetite \pm K-silicate \pm pyrite \pm calcsilicate \pm apatite \pm carbonate \pm quartz

early deep $\mathrm{Na} \pm \mathrm{Ca}$ regional alteration (e.g. albite-actinolite)

host rock - metasedimentary and/or (meta) igneous

C. Arc-hosted Cu-Au-Fe including IOCG deposits

early

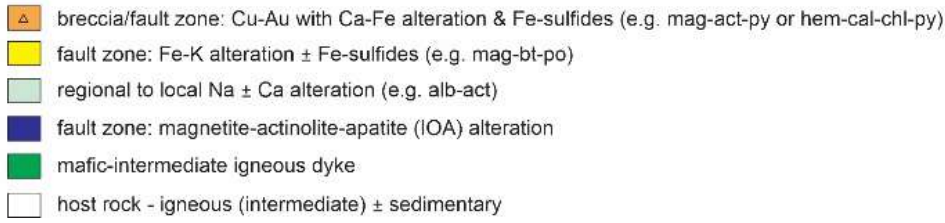

Figure 6. Schematic cross sections of deposit-scale zoning and paragenetic sequences of hydrothermal alteration-mineralisation assemblages in $\mathrm{Cu}-\mathrm{Au}-\mathrm{Fe}( \pm \mathrm{Co}, \mathrm{REE})$ including IOCG deposits. A: syn-orogenic settings; B: post-orogenic settings (with examples from the Gawler Craton - PH: Prominent Hill, Carr.: Carrapateena, OD: Olympic Dam Cu-Au-U-REE deposits); C: arc-hosted settings (e.g. Chilean and Peruvian Andes deposits, based on Sillitoe, 2003).

In syn-orogenic settings structurally favourable sites along ductile to brittle-ductile shear zones (e.g. dilational jogs at rheological contrasts in local geology) commonly control the overall distribution of alteration-mineralisation. The geometric patterns of overprinting mineral assemblages vary greatly in detail between deposits (Fig. 6A). For example, the size of each zone representing a particular hydrothermal assemblage varies such that a later zone may be smaller than an earlier zone and hence appear nested within the earlier alteration; alternatively a more extensive later zone may result in 'enclaves' of earlier alteration zones, or complete replacement of earlier by later assemblages. It should be noted that some zoning and overprinting effects may simply result from migration of alteration fronts away from fluid channelways, reflecting varying fluid:rock ratios. Also shown in Figure $6 \mathrm{~A}$ is the hypothetical setting of a $\mathrm{Cu}-\mathrm{Au}-\mathrm{Fe}( \pm \mathrm{Co}, \mathrm{REE})$ deposit lacking significant Fe-oxides, i.e. an ISCG deposit (at right). 
The post-orogenic setting of the Gawler Craton is typified by breccia-hosted deposits with hydrothermal mineral zoning that can be interpreted in terms of progressive migration of upward-convex shells of alteration-mineralisation towards the paleo-surface. At the Prominent Hill deposit Schlegel \& Heinrich, 2015 proposed a series of nested upward-convex zones resulting from upflow and migration of hydrothermal fluids, as simplified in Figure 6B. This concept has been extended to other zoned deposits in the eastern Gawler Craton in Figure 6B. For example at Carrapateena the sub-vertical pipe-like morphology of the hematite-rich breccia zones and $\mathrm{Cu}-\mathrm{Fe}$ sulfide zones (Porter, 2010b) can be interpreted to indicate migration of alterationmineralisation zones to a higher structural level than at Prominent Hill, with subsequent erosion to a mid or lower level in the horizontally zoned system. The flared-upward zoning of $\mathrm{Cu}-\mathrm{Fe}$ sulfides and other hydrothermal assemblages at Olympic Dam (Reeve et al., 1990; Haynes et al., 1995; Ehrig et al., 2012) could represent a further progression in which the hydrothermal and breccia system breached the paleosurface to form a broad funnel-shaped body with Cu-poor hematite-quartz alteration in the upper-centre of the deposit.

Schematic zoning within $\mathrm{Cu}-\mathrm{Au}-\mathrm{Fe}$ deposits in arc-hosted settings is shown in Figure 6C, based on the model of Sillitoe (2003). A possible spatial and temporal relationship between IOA deposits and the $\mathrm{Cu}-\mathrm{Au}-\mathrm{Fe}$ including IOCG deposits is also illustrated, with structural control by extensional and/or transtensional mostly brittle fault zones. Reactivation of such fault zones may result in local overprinting of IOA deposits by $\mathrm{Cu}-\mathrm{Au}$ mineralisation although the two deposit types also occur independently. A close spatial relationship with mafic-intermediate magmatism is also indicated (Sillitoe, 2003), in contrast to the syn- and post-orogenic $\mathrm{Cu}-\mathrm{Au}-\mathrm{Fe}( \pm \mathrm{Co}, \mathrm{REE}$ ) deposits where magmatism is broadly coeval with, but almost invariably distal from, the $\mathrm{Cu}-\mathrm{Au}$ Fe $( \pm$ Co, REE) deposits.

\subsection{Regional alteration}

Regional-scale hydrothermal alteration, characterised particularly by Na- and Na-Ca-rich mineral assemblages, is a key feature of almost all metallogenic provinces hosting $\mathrm{Cu}-\mathrm{Au}-\mathrm{Fe}( \pm \mathrm{Co}, \mathrm{REE})$ including IOCG deposits. Host rocks of widely varying composition are altered to combinations of albite, calcsilicates such as actinolitic amphibole, diopside (commonly salitic) and much less common Fe-Ca garnet, marialitic scapolite, and minor titanite. Sodic alteration with minor or no calcsilicates is commonly dominated by albite-quartz and can result in wholesale 'bleaching' of precursor rocks. Calc-silicate-rich domains range in dimensions from 100s of metres to a few centimetres, and commonly are associated with brecciation. In syn-orogenic hydrothermal systems such breccias with $\mathrm{Na}$-Ca alteration are typically syn-tectonic, forming for example along brittle-ductile shear zones and in mesoscopic fold hinges. Assemblages transitional between Na$\mathrm{Ca}$ and $\mathrm{Fe}-\mathrm{K}$ may include biotite or magnetite, but the timing relationships between regional Na$\mathrm{Ca}$ and regional $\mathrm{Fe}-\mathrm{K}$ alteration are unclear in most provinces where both types of alteration are present, often because the two regional alteration types are not juxtaposed (e.g. Gawler Craton, Curnamona Province, Cloncurry). However, at deposit scales it is more evident that Fe-K overprints $\mathrm{Na}-\mathrm{Ca}$ alteration, and hence we may assume this to be the case in regional alteration systems. Surprisingly, in only a few provinces have the absolute timing relationships between regional $\mathrm{Na}-\mathrm{Ca}$ alteration and $\mathrm{Cu}-\mathrm{Au}$ mineralisation been well constrained by geochronology (see compilation in the Supplementary Information). For example in the Cloncurry and Curnamona provinces several regional $\mathrm{Na} \pm \mathrm{Ca}$ alteration events have been documented, but only some were 
coeval with $\mathrm{Cu}-\mathrm{Au}$ mineralisation events (Skirrow et al., 2000; Teale \& Fanning, 2000; Duncan et al., 2011). The complex magmatic, tectonic and metallogenic-hydrothermal history of the KirunaNorbotten province (Martinsson et al., 2016) is an instructive case study where the few available $\mathrm{U}-\mathrm{Pb}$ dates for prominent regional $\mathrm{Na}-\mathrm{Ca}$ alteration show this metasomatism to be coeval with the first of two syn-orogenic $\mathrm{Cu}-\mathrm{Au}-\mathrm{Fe}( \pm \mathrm{Co}$, REE) mineralisation events at $\sim 1850-1865 \mathrm{Ma}$ (Supplementary Information). Importantly, the dated major IOA deposits formed significantly prior to the regional Na-Ca and syn-orogenic $\mathrm{Cu}-\mathrm{Au}-\mathrm{Fe}$ ( $\pm \mathrm{Co}$, REE) mineralisation, at 1875-1885 Ma. More generally, the extent and intensity of regional Na-Ca alteration in provinces with IOA deposits and lacking significant orogenic-related or arc-hosted $\mathrm{Cu}-\mathrm{Au}-\mathrm{Fe}$ deposits (e.g. MLYB, Bafq, Southeast Missouri, Adirondacks) appears to be more limited than in the $\mathrm{Cu}-\mathrm{Au}-\mathrm{Fe}( \pm \mathrm{Co}$, REE) provinces.

\subsection{Mineralogical classification of $\mathrm{Cu}-\mathrm{Au}-\mathrm{Fe}( \pm \mathrm{Co}, \mathrm{REE})$ deposits}

\subsubsection{Redox - sulfur - iron mineralogical framework - the CGI cube}

The compilation of paragenetic sequences of hydrothermal minerals presented above shows that Fe-rich $\mathrm{Cu}-\mathrm{Au}$ deposits contain highly variable abundances and ratios of Fe-oxide and Fe-sulfide minerals. Although highly diverse it is apparent that the characteristic Fe-oxide-sulfide mineralogies of different deposits vary systematically with the occurrences of $\mathrm{Cu} \pm \mathrm{Fe}$ sulfides (chalcopyrite, bornite, chalcocite), alteration minerals, and with the relative abundances of key minor elements (e.g. Co, Ni, U, REE, Ba, F, Mo). Furthermore, the patterns of co-variation of hydrothermal minerals can be described in terms of variations in (a) oxidation-reduction (redox) state of the observed mineral assemblages, (b) the ratio of Fe-oxides to Fe-sulfides which relates to the sulfur contents of the hydrothermal fluids, and (c) the relative timing of Fe-oxides and $\mathrm{Cu}$ Fe sulfides. These three variables are illustrated schematically in Figure 7, termed the 'CGI cube', where the Fe-oxide, Fe-sulfide and $\mathrm{Cu} \pm$ Fe sulfide mineralogy of the dominant ore assemblages of individual deposits are represented by small volumes within a three-dimensional space. Continuums of deposit mineralogy are represented along each axis of the cube. Groups of deposits with similar and related mineralogy and geochemistry are shown in generalised form as volumes in the CGI cube in Figure 8. For detailed presentations of deposit mineralogy in each of the major $\mathrm{Cu}-\mathrm{Au}-\mathrm{Fe}( \pm \mathrm{Co}, \mathrm{REE})$ provinces the reader is referred to Appendix 2 . 


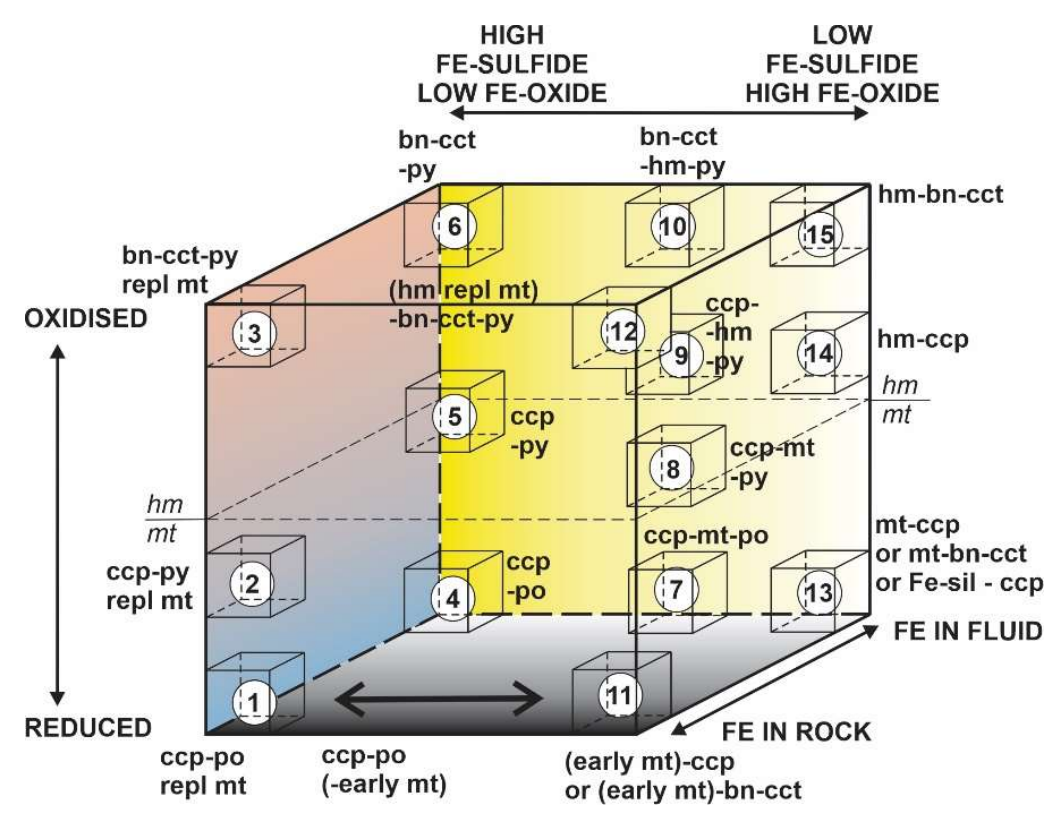

Figure 7. Three-dimensional depiction of CGI deposit mineralogy (the CGI cube) based on predominance of $\mathrm{Fe}$ - versus $\mathrm{S}$-rich minerals in $\mathrm{Cu}-\mathrm{Au}$ mineralisation (x-axis), interpreted redox state of key $\mathrm{Fe}-\mathrm{O}-\mathrm{S}-\mathrm{Cu}$ minerals (y-axis), and interpreted source of Fe at the ore depositional site (z-axis, Fe in fluid versus Fe in host rock). Continuums exist between most of the end-member groups.

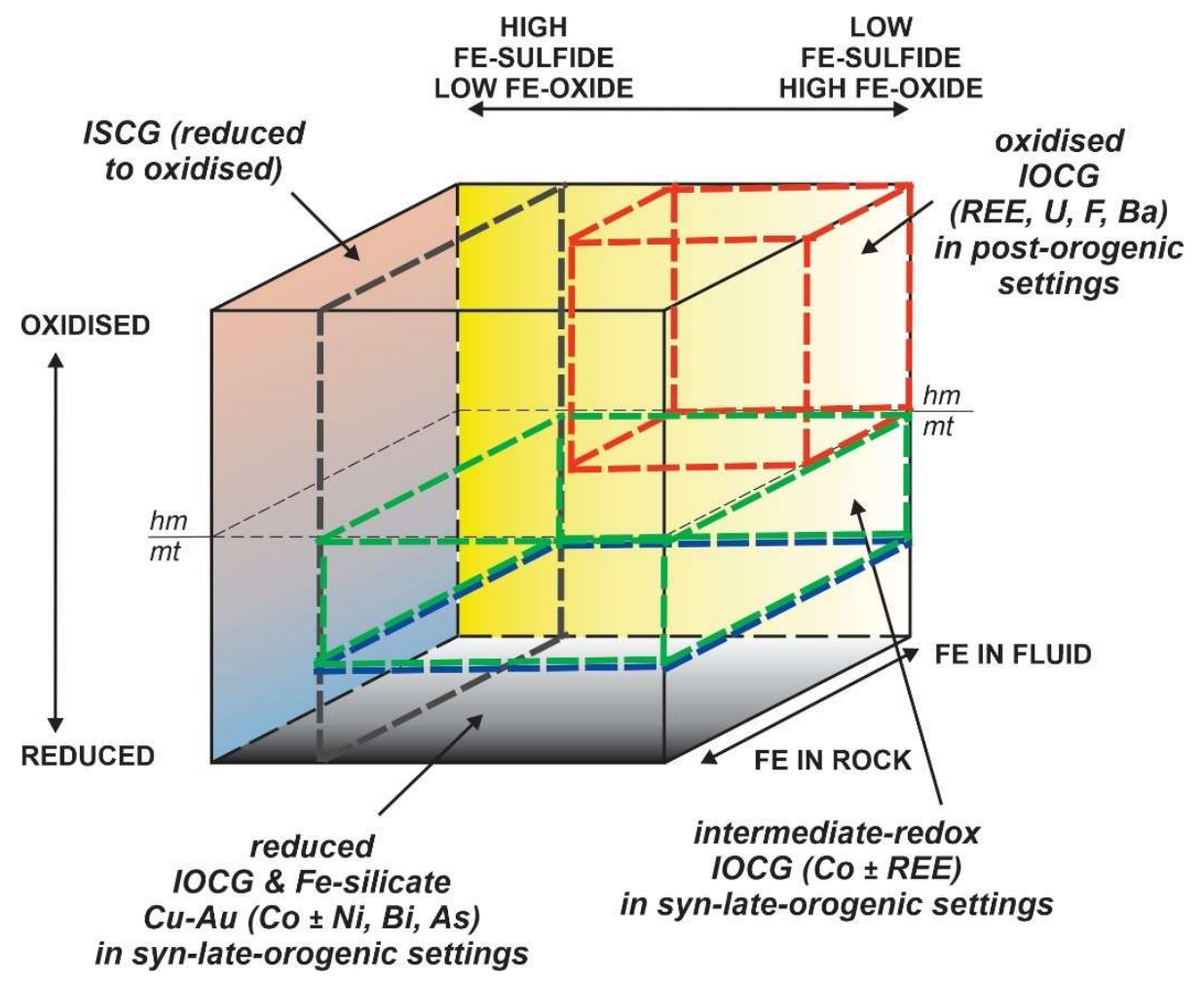

Figure 8. CGI cube of deposit mineralogy, as for Figure 7, showing generalised volumes representing three mineralogical-geochemical sub-types of $\mathrm{Cu}-\mathrm{Au}-\mathrm{Fe}( \pm \mathrm{Co}, \mathrm{REE})$ including IOCG deposits in different tectonic settings (oxidised, intermediate-redox and reduced). Also shown for comparison are volumes for Fe-sulfide $\mathrm{Cu}-\mathrm{Au}$ (ISCG) deposits lacking Fe-oxides (not IOCG deposits). 
The variations in observed oxide and sulfide mineralogy represented in the CGI cube can be understood in terms of the thermodynamic stabilities of the key Fe-oxides, Fe-sulfides and silicates, as shown in the activity diagram in Figure 9. Although depicted for specific conditions $\left(300^{\circ} \mathrm{C}, \mathrm{pH}=5\right.$, etc) the topology of the stability fields of the minerals will remain roughly similar at slightly higher or lower temperatures (e.g. $250-350^{\circ} \mathrm{C}$ ). The y-axis in Figures 7 and 8 represents the redox state of the observed mineral assemblages, one of the most important parameters in characterising $\mathrm{Cu}-\mathrm{Au}-\mathrm{Fe}( \pm \mathrm{Co}, \mathrm{REE})$ deposits. Oxidised assemblages are defined as those containing hematite at high values of $\operatorname{logfO} \mathrm{O}_{2}$, whereas reduced assemblages are defined as those at low $\operatorname{logfO}_{2}$ containing pyrrhotite and/or Fe-silicates such as grunerite or minnesotaite (boundary at $\sim 350-370^{\circ} \mathrm{C}$, Miyano \& Klein, 1989), with or without magnetite and pyrite. Assemblages of intermediate redox contain magnetite and/or Fe-silicates with or without pyrite, but without either pyrrhotite or hematite. At a $\mathrm{pH}$ of 5 and at $300^{\circ} \mathrm{C}$ the hematite-magnetite boundary lies close to the predominance field boundary between oxidised sulfur (aqueous $\mathrm{HSO}_{4}$ or $\mathrm{SO}_{4}{ }^{2-}$ ) and reduced sulfur (aqueous $\mathrm{H}_{2} \mathrm{~S}$ or $\mathrm{HS}$ ), which represents another useful demarcation between oxidised and reduced hydrothermal conditions (albeit pH-dependant).

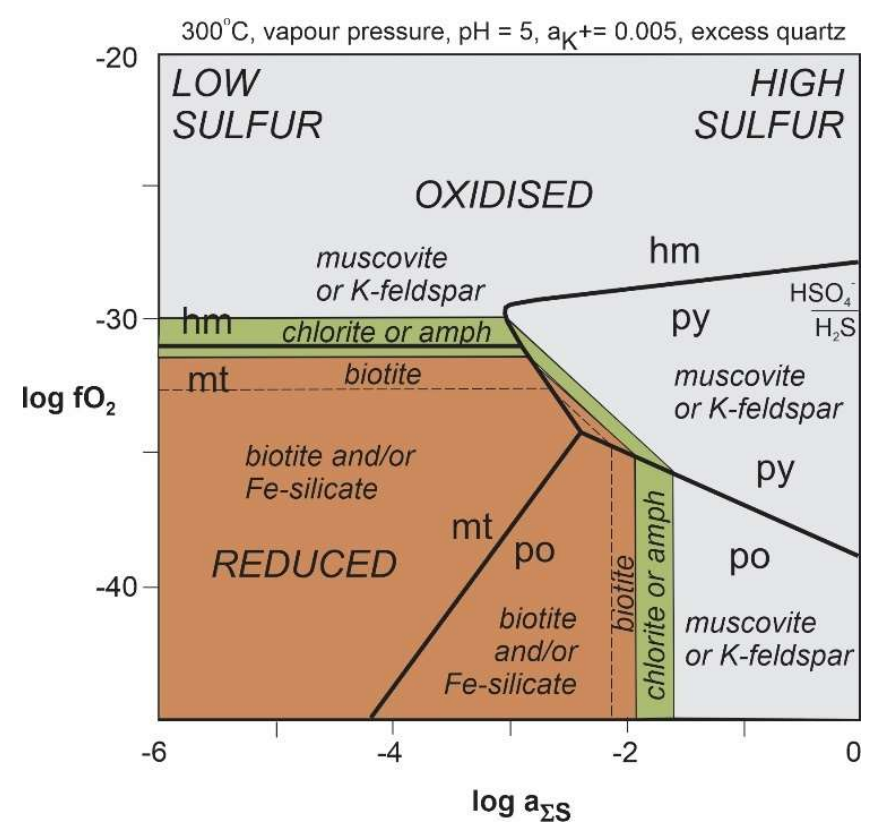

Figure 9. Activity diagram of oxygen fugacity $\left(\log \mathrm{fO}_{2}\right)$ versus total aqueous sulfur activity $\left(\log \mathrm{a}_{\mathrm{ss}}\right)$ at $300^{\circ} \mathrm{C}$, showing stability fields for Fe oxides and sulfides along with silicates in the system Fe-O-H-S-Si-Al-K. This diagram may be used as a 'legend' for the CGI cube in Figures 7 and 8. Muscovite is the stable K-silicate at $\mathrm{pH}=5$, as illustrated; $\mathrm{K}$-feldspar is stable at $\mathrm{pH}>6.5$ for activity of $\mathrm{K}^{+}=0.001$, or at $\mathrm{pH}>5.5$ for activity of $\mathrm{K}^{+}=0.01$. At higher temperatures Fe-amphibole would occupy approximately the field of chlorite. Parts of the biotite field may be occupied by stilpnomelane and/or Fe-silicates such as minnesotaite or grunerite under certain conditions (e.g. differing activity of $\mathrm{K}^{+}$or temperature). Figure modified from Skirrow \& Walshe (2002).

The x-axis in Figures 7 and 8 represents the observed relative abundances of Fe-sulfides and Feoxides in the deposits. This ratio generally reflects the concentrations of sulfur in the fluid relative 
to the abundances of $\mathrm{Fe}$, whether as Fe-oxides in the rock or dissolved iron in the fluid. At the extreme left side of the CGI cube are deposits lacking Fe-oxides and containing abundant Fesulfides as well as $\mathrm{Cu} \pm$ Fe sulfides. Examples of such deposits in the Cloncurry province have been termed 'iron sulfide copper-gold' or 'ISCG' deposits (Haynes, 2000), and in the Tennant Creek province have been termed 'non-ironstone $\mathrm{Cu}-\mathrm{Au}$-Bi deposits' (Skirrow, 1993, 2000; Skirrow \& Walshe, 2002); in fact many $\mathrm{Cu}-\mathrm{Au}-\mathrm{Fe}$ ( $\pm \mathrm{Co}, \mathrm{REE}$ ) provinces contain examples of reduced to oxidised Fe-oxide-deficient $\mathrm{Cu}$-Au deposits, which appear to form a continuum with otherwise structurally and temporally similar Fe-oxide-bearing $\mathrm{Cu}-\mathrm{Au}$ deposits (Figs. 7, 8; Appendix 2). Moreover, individual deposits may be internally zoned from massive $\mathrm{Fe}-\mathrm{Cu}$ sulfide ore zones outwards through Fe-oxide-poor sulfide-rich zones to outer Fe-oxide-rich sulfide-poor zones (see thick arrow along $\mathrm{x}$-axis in Fig. 7, e.g. West Peko deposit, Tennant Creek province). At the extreme right side of the CGI cube are Fe-oxide-rich deposits with little or no Fe-sulfide accompanying the $\mathrm{Cu} \pm \mathrm{Fe}$ sulfides (e.g. Salobo, Carajás province, and significant parts of the Olympic Dam and Prominent Hill Cu-Au-U-REE deposits, Gawler Craton).

The z-axis in the CGI cube represents the interpreted timing of Fe-oxide deposition relative to $\mathrm{Cu}$ \pm Fe sulfides, based on the compilation of paragenetic sequences in Figure 4. There are two endmember scenarios represented by the 'front face' and 'back face' of the CGI cube, respectively: (1) all of the Fe-oxides pre-dated $\mathrm{Cu}$-Au mineralisation in separate hydrothermal or sedimentary events (e.g. sedimentary banded iron formation); and (2) all of the Fe-oxides were deposited more or less contemporaneously with the $\mathrm{Cu}-\mathrm{Au}$ mineralisation during evolution of an hydrothermal system. Examples of scenario (1) include the 'ironstone'-hosted $\mathrm{Au}-\mathrm{Cu}$-Bi deposits of the Tennant Creek province, parts of the Osborne, Starra and Monakoff deposits (Cloncurry province), parts of the Salobo deposit (Carajás province), and the Emmie Bluff prospect (Gawler Craton). In most other $\mathrm{Cu}-\mathrm{Au}-\mathrm{Fe}( \pm \mathrm{Co}, \mathrm{REE})$ deposits major proportions of the observed $\mathrm{Fe}-$ oxides occurring in $\mathrm{Cu}-\mathrm{Au}$ ore zones were deposited directly from hydrothermal fluids either during $\mathrm{Cu}-\mathrm{Au}$ mineralisation or immediately beforehand in an evolving system. Good examples include the Ernest Henry deposit where chalcopyrite and pyrite were deposited during the same paragenetic stage as magnetite (Mark et al., 2006), and the Prominent Hill deposit where bornitechalcocite-chalcopyrite formed with large quantities of hematite (Schlegel \& Heinrich, 2015). Cases where both 'early' Fe-oxides and syn-Cu-Au Fe-oxides occur within the same deposit (i.e. part way along the z-axis in Figs. 7 and 8) may include the Salobo deposit with BIF overprinted by hydrothermal magnetite and $\mathrm{Cu} \pm$ Fe sulfides (de Melo et al., 2017), and in the Gawler Craton where early magnetite \pm apatite \pm carbonate alteration was overprinted $\sim 4$ m.y. later by $\mathrm{Cu}-\mathrm{Au}$ with abundant hematite (e.g. Olympic Dam deposit and Acropolis prospect, Gawler Craton; ((Cherry et al., 2018; Ehrig et al., 2012; Haynes et al., 1995; James P. Johnson \& McCulloch, 1995; McPhie et al., 2020; Oreskes \& Einaudi, 1990; Reeve et al., 1990)).

\subsubsection{Oxidised, intermediate-redox and reduced sub-groups}

Both the $\mathrm{Cu} \pm \mathrm{Fe}$ sulfides and silicate alteration mineralogy vary systematically with the Fe-oxide and Fe-sulfide assemblages across the CGI cube. The $\mathrm{Cu}-\mathrm{Au}-\mathrm{Fe}( \pm \mathrm{Co}, \mathrm{REE})$ deposits can be classified into 3 mineralogical sub-groups according to their dominant ore-related assemblages, which broadly correlate with the three geological-tectonic settings defined earlier (Fig. 8).

In the oxidised Fe-oxide $\mathrm{Cu}-\mathrm{Au}$ (REE, U, F, Ba) group (red-outlined volume in Fig. 8) highly oxidised and S-poor hematite-white mica zones (right-top edge of CGI cube, and top-left part of Fig. 8) may contain little or no sulfides or $\mathrm{Cu}$ but can be enriched in Au and/or REE, for example 
the upper and/or inner zones at Olympic Dam and Prominent Hill. Such zones also may represent the most acidic conditions (e.g. Prominent Hill, Schlegel et al., 2015, 2018). Moderately oxidised hydrothermal assemblages generally contain hypogene bornite \pm chalcocite with hematite \pm pyrite and white mica (at low $\mathrm{pH}$ ) or potentially K-feldspar (at high $\mathrm{pH}$ ), as shown in Figure 9. These bornite \pm chalcocite assemblages transition downwards and/or outwards into less oxidised chalcopyrite-pyrite-hematite assemblages where chlorite may be present with white mica (e.g. Olympic Dam, Reeve et al., 1990). Examples are present in many other IOCG-bearing provinces. These include late-stage hematite- and U-bearing chalcopyrite (-Au) mineralisation at the Sue Dianne deposit (Great Bear magmatic zone), and the paragenetically late hematitebearing stage at Starra (Cloncurry province) where Au-rich mineralisation is associated with bornite, chalcopyrite, chalcocite, pyrite, chlorite, anhydrite, carbonate and later white mica (Rotherham et al., 1998). However, unlike the oxidised deposits of the Gawler Craton the latestage $\mathrm{Au}-\mathrm{Cu}$ at Starra is not REE-U-F-Ba-rich. This also appears to be the case in the hematite-rich examples of $\mathrm{Au}-\mathrm{Cu}-\mathrm{Bi}$ deposits in the Tennant Creek province and at the Cristalino deposit (Carajás province). Similarly, although hematite- and $\mathrm{Cu}$-rich breccia at the Mantoverde deposit (Chilean Andean province) is weakly enriched in the LREE (e.g. up to $10 \mathrm{x}$ local andesitic values), it contains very low $\mathrm{U}$ and lacks fluorite, barite, and hypogene bornite and chalcocite (Rieger et al., 2010). Copper deposits described as 'sedimentary stratiform copper' or 'SSC' deposits in the Kangdian province (e.g. Hongnipo deposit, Lin et al., 2020) and in the Khetri province (Knight et al., 2002; Mukhopadhyay et al., 2019) are probably other examples of the iron sulfide $\mathrm{Cu}-\mathrm{Au}$ subgroup of deposits.

Deposits with intermediate-redox assemblages (green-outlined volume in Fig. 8) have $\mathrm{Cu}$-Au ore assemblages bearing variable modal proportions of magnetite, lack pyrrhotite or hematite, and contain chalcopyrite as the dominant $\mathrm{Cu}$-bearing sulfide. Minor hypogene bornite is commonly present but bornite \pm chalcocite dominating over chalcopyrite appears to be rare (e.g. Salobo). Many of the deposits in the Carajás, Cloncurry, Kangdian and Tennant Creek provinces are considered here to be members of the intermediate-redox group of $\mathrm{Cu}-\mathrm{Au}-\mathrm{Fe}$ ( $\pm \mathrm{Co}$, REE) deposits. Silicate mineralogy in the $\mathrm{Cu}-\mathrm{Au}$ ore-associated assemblages is generally dominated by Fe-K-rich phases such as biotite or rare stilpnomelane, and/or Fe-Ca-rich phases such as actinolite or garnet, and/or Fe-rich silicates such as chlorite, grunerite, and uncommon fayalite, minnesotaite or greenalite. The stability relationships of some of these minerals is shown in Figure 9 where it is clear that both the redox conditions and sulfur content of the fluids (among other parameters) are important in determining the particular oxide-sulfide-silicate assemblages at individual $\mathrm{Cu}-\mathrm{Au}-\mathrm{Fe}( \pm \mathrm{Co}, \mathrm{REE})$ deposits. The intermediate-redox $\mathrm{Cu}-\mathrm{Au}-\mathrm{Fe}( \pm \mathrm{Co}, \mathrm{REE})$ deposits are highly variable in the reported occurrences of minerals hosting REE, $\mathrm{U}, \mathrm{Co}, \mathrm{Ni}, \mathrm{Bi}, \mathrm{Mo}$ and other ore elements, as noted above (Fig. 4). There may be a sub-group of the intermediateredox deposits that exhibit anomalous to very high REE contents and which may be transitional to the oxidised $\mathrm{Cu}-\mathrm{Au}-\mathrm{Fe}$ group (e.g. Sin Quyen, SWAN, Monakoff, E1, Ernest Henry; see also Ore Geochemistry section, below).

A third mineralogical group of $\mathrm{Cu}-\mathrm{Au}-\mathrm{Fe}( \pm \mathrm{Co}, \mathrm{REE})$ deposits is represented by the most reduced assemblages, with pyrrhotite and/or Fe-silicates and variable modal proportions of magnetite and pyrite (blue-outlined volume, Fig. 8). Chalcopyrite is the dominant $\mathrm{Cu}$ sulfide with minor bornite in some deposits. Examples range from magnetite-pyrrhotite-pyrite-rich deposits (e.g. Osborne, Raúl-Condestable, Candelaria, Sin Quyen, Lala, NICO), and some with Fe-silicates such as West Peko (minnesotaite, greenalite), to pyrrhotite-rich deposits or zones lacking magnetite 
(e.g. Eloise, Dahongshan, Mt Elliott eastern zone) or containing only minor magnetite (e.g. Guelb Moghrein, Sequeirinho-Sossego). It is notable that reported occurrences of minor minerals in the reduced $\mathrm{Cu}-\mathrm{Au}-\mathrm{Fe}( \pm \mathrm{Co}, \mathrm{REE}$ ) deposit group commonly includes phases hosting $\mathrm{Co}, \mathrm{Ni}, \mathrm{As}$ and $\mathrm{Bi}$ but very rarely REE- or U-rich phases nor fluorite, barite or anhydrite.

Finally, qualitative comparison of the mineralogy of $\mathrm{Cu}-\mathrm{Au}-\mathrm{Fe}( \pm \mathrm{Co}, \mathrm{REE})$ deposits considered herein with porphyry $\mathrm{Cu}-\mathrm{Au}$ deposits shows the latter to typically have much more restricted ranges of redox and Fe-oxide/Fe-sulfide ratios than the $\mathrm{Cu}-\mathrm{Au}-\mathrm{Fe}( \pm \mathrm{Co}$, REE) deposits. Porphyry deposits would be represented in Figure 8 by a volume within the Fe-sulfide $\mathrm{Cu}-\mathrm{Au}$ (ISCG) volume. Intrusion-related magmatic-hydrothermal skarn $\mathrm{Fe}-\mathrm{Cu}$ deposits (not shown in Fig. 8) would occupy a volume of reduced to intermediate-redox space and widely varying magnetite/Fe-sulfide ratio along the 'back face' of the CGI cube, and hence overlap with some of the deposits considered to be members of the orogenic-related and Andean-type arc-hosted groups of $\mathrm{Cu}-\mathrm{Au}-\mathrm{Fe}( \pm \mathrm{Co}, \mathrm{REE})$ deposits. Nevertheless, there are geochemical differences between deposit types that are discussed in following sections.

\section{Geochemical characterisation of $\mathrm{Cu}-\mathrm{Au}-\mathrm{Fe}( \pm \mathrm{Co}, \mathrm{REE})$ deposits}

The recent availability of high-quality internally consistent whole-rock geochemical data for a large number of ore deposits worldwide enables comparisons of IOCG with other deposit types (OSNACA data base, Brauhart \& Hagemann, 2020). Although data are currently available for only a few samples of any particular deposit, these samples are believed to be representative of key ore types, and sufficient data are available to identify broad similarities and differences between groups and subgroups of deposits. A more comprehensive additional OSNACA data set for the Cloncurry province was included in the present study (data extracted 2019-2020). The deposits are listed in Appendix 3. Those attributed as IOCG deposits in the OSNACA data set have been carefully assessed against the characteristics of the syn- and post-orogenic and Andean-type arcrelated $\mathrm{Cu}-\mathrm{Au}-\mathrm{Fe}( \pm \mathrm{Co}, \mathrm{REE})$ deposits as defined in this review. Deposits with the characteristics of the $\mathrm{Cu}-\mathrm{Au}-\mathrm{Fe}( \pm \mathrm{Co}, \mathrm{REE})$ deposits have been assigned to mineralogical subgroups in the present study according to their dominant ore-related oxide-sulfide-silicate mineralogy, redox conditions based on mineralogy, and settings, following Figure 7. This mineralogical-redox framework was then used to compare the ore geochemistry between (a) mineralogical subtypes within the family of $\mathrm{Cu}-\mathrm{Au}-\mathrm{Fe}( \pm \mathrm{Co}, \mathrm{REE})$ deposits, and (b) $\mathrm{Cu}-\mathrm{Au}-\mathrm{Fe}( \pm \mathrm{Co}, \mathrm{REE})$ deposits and other selected ore deposit types, as described below.

\subsection{Geochemical subdivision of $\mathrm{Cu}-\mathrm{Au}-\mathrm{Fe}( \pm \mathrm{Co}, \mathrm{REE})$ deposits - the CGI discriminator}

The $\mathrm{Cu}-\mathrm{Au}-\mathrm{Fe}( \pm \mathrm{Co}, \mathrm{REE})$ ores attributed as IOCG deposits in the OSNACA data set display large variations in the relative abundances of the chalcophile-siderophile elements (e.g. Co, $\mathrm{Ni}, \mathrm{Bi}, \mathrm{Se}$, Te) and selected HFSE and LILE (e.g. U, REE, Mo). A simple ratio of $(\mathrm{Co}+\mathrm{Ni}+10 * \mathrm{Bi}+10 * \mathrm{Se}+50 * \mathrm{Te}) /(\mathrm{U}+\mathrm{La})$ using ppm values reveals a striking spectrum of values between sub-groups of $\mathrm{Cu}-\mathrm{Au}-\mathrm{Fe}( \pm \mathrm{Co}, \mathrm{REE}$ ) deposits (Fig. 12). Importantly, differing values of the CGI discriminator correlate broadly with the documented ore-related mineralogy and with the redox conditions interpreted herein (Fig. 7). As these hydrothermal conditions have been determined independently from the geochemical data, the correlations in Figure 12 are considered to be a fundamental feature of the $\mathrm{Cu}-\mathrm{Au}-\mathrm{Fe}( \pm \mathrm{Co}, \mathrm{REE})$ family of deposits. Moreover, 
there appears to be a weak inverse correlation between the $\mathrm{Au} / \mathrm{Cu}$ ratio and the $\mathrm{CGI}$ discriminator index, such that the more oxidised ores tend to have higher $\mathrm{Au} / \mathrm{Cu}$ ratios than the relatively reduced and $\mathrm{Cu}$-rich ores (Fig. 12).

The variations in key element suites are also clearly evident in plots of individual elements representing the suites. For example, Figure 13 plots La versus Co (with symbol size proportional to $\mathrm{U}$ content), and discriminates four geochemical subgroups of $\mathrm{Cu}-\mathrm{Au}-\mathrm{Fe}( \pm \mathrm{Co}, \mathrm{REE})$ ores. These have been defined with nominal boundaries at $100 \mathrm{ppm}$ Co and $100 \mathrm{ppm}$ La. The four subgroups are listed below, followed by detailed descriptions.

Subgroup (1): 'CGI-Co' ores with moderate to high enrichments in the chalcophile and siderophile elements $\mathrm{Co}+\mathrm{Ni}+\mathrm{Bi}+\mathrm{Se}+\mathrm{Te}$, and with low $\mathrm{U}$ and REE contents; these deposits also lack fluorite (F) and barite (Ba) with the $\mathrm{Cu}$ sulfides (Fig. 5).

Subgroup (2): 'CGI-REE' ores highly enriched in selected HFSE and LILE, in particular REE and/or $\mathrm{U}$, which commonly also have high Mo (and F, Ba, not reported in OSNACA but evident in Fig. 5), and low $\mathrm{Co}+\mathrm{Ni}+\mathrm{Bi}+\mathrm{Se}+\mathrm{Te}$ contents.

Subgroup (3): 'CGI-Co-REE' ores with geochemistry transitional between subgroups (1) and (2), with moderate to strong enrichments in both the $\mathrm{Co}+\mathrm{Ni}+\mathrm{Bi}+\mathrm{Se}+\mathrm{Te}$ and $\mathrm{REE}-\mathrm{U}-\mathrm{Mo}-\mathrm{F}-\mathrm{Ba}$ groups of elements.

Subgroup (4): CGI ores without strong enrichments in either the $\mathrm{Co}+\mathrm{Ni}+\mathrm{Bi}+\mathrm{Se}+\mathrm{Te}$ group or the REE-U-Mo-F-Ba group of elements (CGI (low Co, REE)). 
y-axis: CGI discriminator

$\left(\mathrm{Co}+\mathrm{Ni}+10^{*} \mathrm{Bi}+10^{*} \mathrm{Se}+50^{*} \mathrm{Te}\right) /(\mathrm{U}+\mathrm{La})($ each element in ppm)

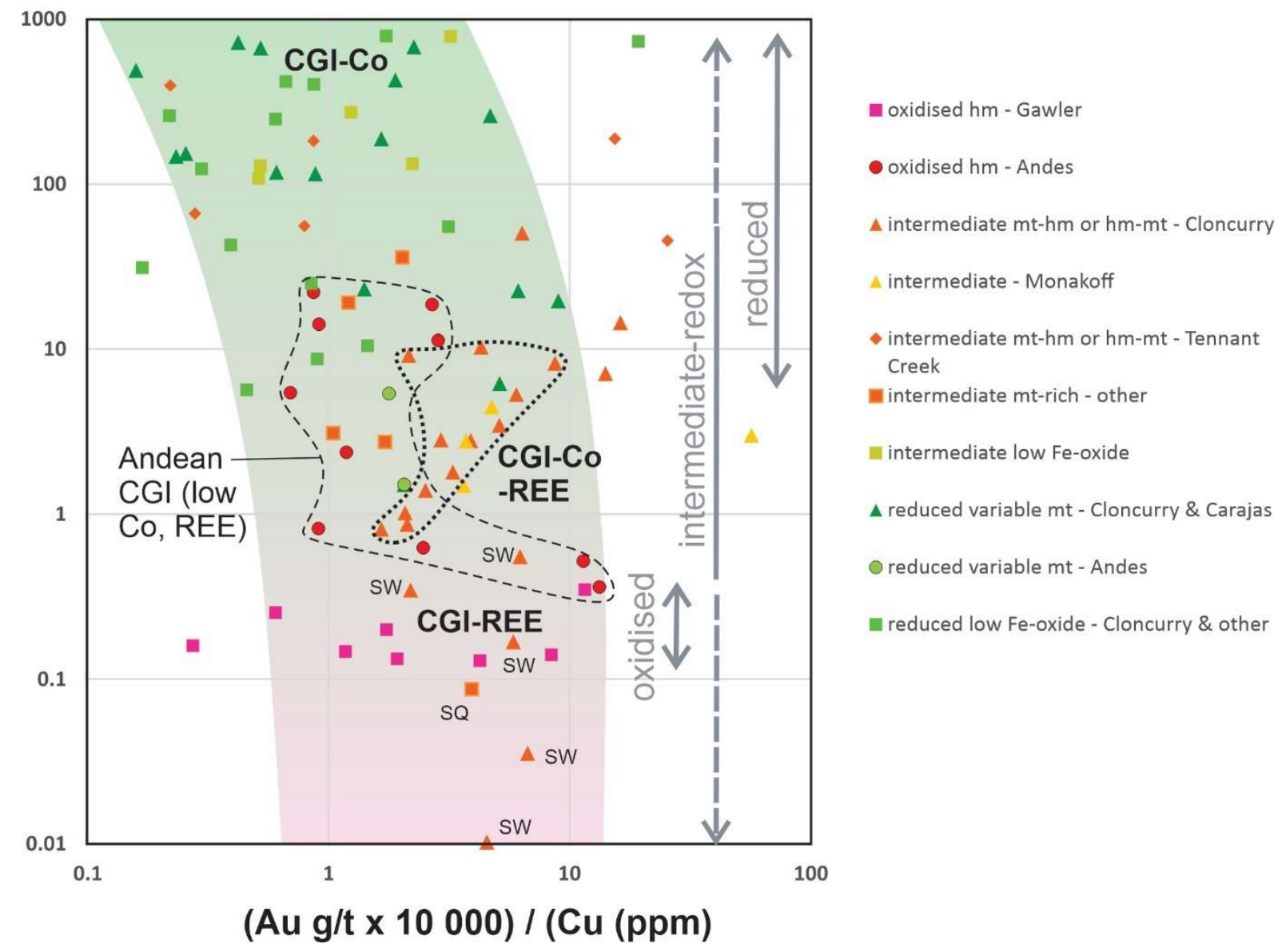

Figure 12. $\mathrm{Cu}-\mathrm{Au}-\mathrm{Fe}( \pm \mathrm{Co}, \mathrm{REE})$ deposit subtype discrimination diagram, showing $\mathrm{Au} / \mathrm{Cu}$ ratio versus the CGI discriminator $(\mathrm{Co}+\mathrm{Ni}+10 * \mathrm{Bi}+10 * \mathrm{Se}+50 * \mathrm{Te}) /(\mathrm{U}+\mathrm{La})$ with each element in ppm. The subtypes of $\mathrm{Cu}-\mathrm{Au}-$ $\mathrm{Fe}( \pm \mathrm{Co}, \mathrm{REE})$ deposits listed in the legend are based on independently determined mineralogical-redox subdivisions (Fig. 7); the generalised ranges of oxidised, intermediate-redox and reduced mineral assemblages are indicated with arrows. The coloured band encloses most data points. Geochemical data from the OSNACA data set (Brauhart \& Hagemann, 2020) with additional data for Mantoverde (Chile, Rieger et al., 2010), Candelaria, Carola and Socavon Rampa (Chile, Marschik \& Fontboté, 2001). Abbreviations: SQ - Sin Quyen, SW - SWAN. 


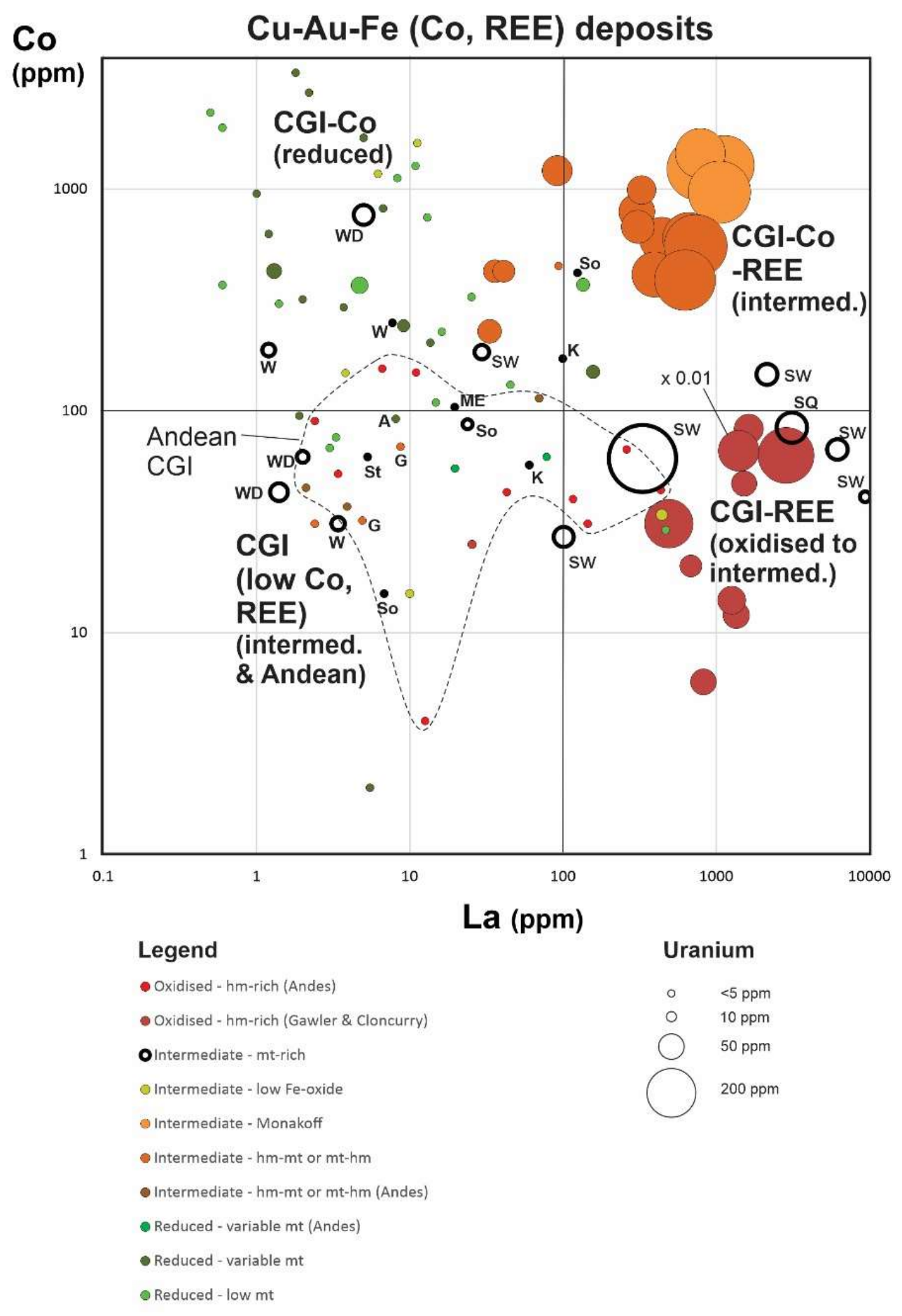

Figure 13. La ( $\mathrm{ppm}$ ) versus Co (ppm) with $\mathrm{U}$ (symbol size) discrimination diagram for geochemical subtypes of $\mathrm{Cu}-\mathrm{Au}-\mathrm{Fe}( \pm \mathrm{Co}$, REE) deposits (CGI-Co, CGI-REE, etc), based on OSNACA ore geochemical data (Brauhart \& Hagemann, 2020). Symbol colours correspond to subtypes of CGI deposits defined independently of the geochemical data, on the basis of mineralogy and oxidation-reduction conditions, following Figure 7. The size of the symbols is proportional to the $U(\mathrm{ppm})$ values; the size of one symbol for an Olympic Dam sample is reduced by a factor of 100 for clarity (labelled $x 0.01$ ). Abbreviations for selected deposits: W - Warrego, WD - White Devil, G - Gecko (all Tennant Creek province); SQ - Sin Quyen, SW SWAN (Cloncurry province); K - Khetri; ME - Mount Elliott, St - Starra (Cloncurry province); So - Sossego, A - Antas (Carajás province). Additional data for Mantoverde (Chile, Rieger et al., 2010), Candelaria, Carola and Socavon Rampa (Chile, Marschik \& Fontboté, 2001). 
The CGI-Co ores of subgroup (1) with moderate to strong enrichments in $\mathrm{Co}+\mathrm{Ni}+\mathrm{Bi}+\mathrm{Se}+\mathrm{Te}$ but low REE and $U$ are generally characterised by variable quantities of magnetite (from very abundant to minor or absent) with pyrrhotite and/or pyrite, chalcopyrite \pm bornite as well as differing combinations of $\mathrm{Fe}^{2+}$-rich silicates such as biotite, phlogopite, actinolite, grunerite, fayalite and/or stilpnomelane. Variations in abundances of magnetite and sulfides may be considerable even within individual deposits. This subgroup lacks syn-sulfide hematite and sulfate minerals such as barite and anhydrite, as well as hypogene chalcocite. The assemblages of subgroup (1) are indicative of relatively reduced to intermediate-redox conditions during $\mathrm{Cu}-\mathrm{Fe}$ sulfide ore deposition (Figs. 7, 9). In the Cloncurry district Fe-oxide-poor $\mathrm{Cu}$-Au deposits, termed iron sulfide copper-gold (ISCG) deposits by Haynes (2000), occur in the same metallogenic province as iron oxide-rich $\mathrm{Cu}-\mathrm{Au}$ (IOCG) deposits and share the same structural controls, timing and alteration with the Fe-oxide-rich deposits. Their reduced mineralogy has been suggested to be due to local reduction of the ore fluid by reductants in the host rocks, such as graphite (Haynes, 2000). However, considered globally, only some of these ISCG deposits occur within or near graphitic units, with many of the pyrrhotite-bearing deposits occurring in non-graphitic host rocks (e.g. Osborne, Cloncurry; Adshead et al., 1998), West Peko (Tennant Creek; Skirrow \& Walshe, 2002), Guelb Moghrein (Mauritania; Kolb et al., 2010; Kolb \& Petrov, 2016; Kirschbaum \& Hitzman, 2016). An alternative explanation is that the reduced nature of the mineral assemblages is inherent to the redox state of the ore fluid, an inference that is supported by the specific high-Co-Ni-Bi-Se-Te geochemistry of this subgroup of $\mathrm{Fe}-\mathrm{Cu}-\mathrm{Au}$ deposits globally, regardless of the host rocks which in many cases are not strongly reduced. Example deposits include: Osborne, Eloise, Kulthor, Lorena (Cloncurry, Australia), Guelb Moghrein (Mauritania), Antas, Sossego-Sequeirinho (Carajás, Brazil), and West Peko (Tennant Creek, Australia).

Ores of geochemical subgroup (2), labelled 'CGI-REE' in Figures 12 and 13, have distinctive low values of $<1$ for the $(\mathrm{Co}+\mathrm{Ni}+10 * \mathrm{Bi}+10 * \mathrm{Se}+50 * \mathrm{Te}) /(\mathrm{U}+\mathrm{La})$ discriminator, in contrast to the CGI-Co ores of subgroup (1). Although there are relatively few deposits represented in OSNACA in this subgroup, the main examples are world-class hematite-rich breccia-hosted $\mathrm{Cu}-\mathrm{Au}$-U-REE deposits in the Gawler Craton, including the Olympic Dam, Prominent Hill and Carrapateena deposits. In addition to $\mathrm{U}$ and LREE, these deposits are also highly anomalous in $\mathrm{Ba}$ and $\mathrm{F}$ as evident from the abundances of barite and fluorite (Reeve et al., 1990; Belperio et al., 2007; Porter, 2010b; Ehrig et al., 2012). The ore-related mineral assemblages are indicative of oxidised hydrothermal conditions and include hematite, barite, chalcocite and bornite (Figs. 7, 9; Reeve et al., 1990; Haynes et al., 1995; Ehrig et al., 2012; Schlegel \& Heinrich, 2015; Schlegel et al., 2018). The Olympic Dam deposit has a remarkably wide range of other anomalously enriched elements that in some cases are zoned across the deposit, such as deep and/or peripheral zones with anomalous Mo, W, Sb, As, Te, Ba and Sn (Ehrig et al., 2012). Minerals representing reduced conditions are absent or rare (e.g. rare pyrrhotite at Olympic Dam, Ehrig et al., 2012). Locally abundant magnetite with siderite, pyrite and chalcopyrite, in the deeper and/or peripheral zones at Olympic Dam, represent hydrothermal conditions of intermediate redox state compared to relatively oxidised upper and/or inner zones (Figs. 7, 9; Reeve et al., 1990; Haynes et al., 1995; Ehrig et al., 2012).

A third subgroup of ores, labelled 'CGI-Co-REE' in Figures 12 and 13, exhibit geochemical signatures that are transitional between the CGI-Co and CGI-REE subgroups, with strong enrichments in both $\mathrm{REE}+\mathrm{U}$ and $\mathrm{Co}+\mathrm{Ni}+\mathrm{Bi}+\mathrm{Se}+\mathrm{Te}$. These ores occur in relatively few deposits as 
presently represented in the OSNACA data set, all within the Cloncurry district (Ernest Henry, Monakoff, and E1 Group deposits). The $\mathrm{Cu}$-Au ores are characterised by generally high ratios of magnetite/hematite and pyrite/pyrrhotite, and they are all relatively Fe-oxide-rich. They mostly lack minerals indicative of strongly reduced conditions (e.g. graphite, pyrrhotite, fayalite, minnesotaite, loellingite) but contain minor to locally abundant minerals representing oxidised conditions (e.g. hematite, barite; Mark et al., 2006; Williams et al., 2015). Typical assemblages with $\mathrm{Cu}-\mathrm{Au}$ mineralisation include magnetite, pyrite, chalcopyrite, biotite, K-feldspar, carbonate, Ca-amphibole, chlorite and quartz. The CGI-Co-REE ores are therefore characterised by hydrothermal assemblages of intermediate-redox state (Figs. 12, 13).

A fourth geochemical subgroup of $\mathrm{Cu}-\mathrm{Au}-\mathrm{Fe}$ ores is evident from Figure 13 (labelled CGI (low Co, REE)), with low Co $(<100 \mathrm{ppm})$, La $(<100 \mathrm{ppm})$ and $U(<5 \mathrm{ppm})$. These ores have CGI discriminator values spanning the range between the CGI-Co and CGI-REE subgroups (similar to the CGI-Co-REE range) even though their $\mathrm{REE}+\mathrm{U}$ and $\mathrm{Co}+\mathrm{Ni}+\mathrm{Bi}+\mathrm{Se}+\mathrm{Te}$ contents are relatively low. Most ores in this subgroup are Fe-oxide-rich and contain magnetite-pyrite-chalcopyrite \pm hematite assemblages typical of intermediate-redox conditions (Figs. 7, 9). Importantly, most of the $\mathrm{Cu}-\mathrm{Au}-\mathrm{Fe}$ ores from the Andean deposits plot within this CGI (low Co, REE) subgroup, with the exception of several samples from the hematite-magnetite-rich Mantoverde deposit which contains enrichments in REE but low U (Rieger et al., 2010). It is noteworthy that this deposit also contains relatively abundant hypogene hematite with chalcopyrite (Benavides et al., 2007; Rieger et al., 2010), whereas other Andean CGI deposits with hematite>>magnetite (Carola, Socavon Rampa, Barreal Seco) have much lower REE abundances. Therefore, with the exception of Mantoverde, the Andean CGI deposits contain relatively low levels of Co, REE and U.

The CGI (low Co, REE) subgroup also contains ore samples from parts of some $\mathrm{Au}-\mathrm{Cu}$-Bi deposits from the Tennant Creek province, although other samples from the same deposits plot within the CGI-Co fields in Figures 12 and 13 (e.g. Warrego, White Devil). When the broader element group of $\mathrm{Co}+\mathrm{Ni}+\mathrm{Bi}-\mathrm{Se}+\mathrm{Te}$ is considered, most of the $\mathrm{Cu}$-rich Tennant $\mathrm{Creek} \mathrm{Au}-\mathrm{Cu}-\mathrm{Bi}$ ores plot within the same geochemical subgroup as the reduced CGI-Co ores from the Cloncurry, Carajás and Guelb Moghrein provinces (Fig. 12), suggesting that the Tennant Creek Au-Cu-Bi deposits are indeed similar geochemically to other deposits in the global $\mathrm{Cu}-\mathrm{Au}-\mathrm{Fe}( \pm \mathrm{Co}, \mathrm{REE}$ ) family (cf. Groves et al., 2010). Nevertheless, some ores with extremely high $\mathrm{Au} / \mathrm{Cu}$ ratios (e.g. White Devil) plot well outside the main trend of $\mathrm{Cu}-\mathrm{Au}-\mathrm{Fe}( \pm \mathrm{Co}, \mathrm{REE})$ deposits in Figure 12, and may represent a separate and later $\mathrm{Au}$ event (see discussion in the Supplementary Information for the Tennant Creek province).

A few deposits have mineralogical features that are inconsistent with the majority of other deposits in their geochemical subgroup. For example, the SWAN $\mathrm{Cu}-\mathrm{Au}$ ores have low IOCG discrimination values and La-Co-U contents similar to those of the oxidised CGI-REE subgroup (Figs. 12, 13), but the deposit has an intermediate-redox mineral assemblage of magnetiteamphibole-pyrite-chalcopyrite-anhydrite with albite and clinopyroxene (Brown \& Porter, 2010). The Sin Quyen deposit may be another example. This origin of these mis-matches is not understood. Interestingly, the Mt Elliott $\mathrm{Cu}$-Au deposit, which is adjacent to the SWAN deposit, is considered to be part of the same hydrothermal system as the SWAN deposit and shares similar mineralisation and alteration mineralogy including minor anhydrite, pyrrhotite, allanite, tourmaline, apatite, biotite and K-feldspar (Brown \& Porter, 2010). Although few data are available in OSNACA, Mt Elliott has a higher IOCG discrimination value (16) than SWAN 0.01 to $0.55)$ and significantly lower REE and U contents. These relationships may indicate that fluids of 
similar sulfate-stable (oxidised) and LREE-rich character to those in CGI-REE deposits were involved at both SWAN and Mt Elliott, producing local anhydrite and LREE enrichments yet without hematite development, perhaps due to high temperatures. These oxidised fluids may have overprinted or coexisted with a more reduced (pyrrhotite-bearing) hydrothermal environment represented at the Mt Elliott deposit. This example illustrates the complexities in the mineralogical and geochemical evolution of the $\mathrm{Cu}-\mathrm{Au}-\mathrm{Fe}( \pm \mathrm{Co}, \mathrm{REE})$ deposits considered herein, which in places resulted in features of hybrid (e.g. multi-stage, or multi-fluid) origin.

\subsection{Geochemical comparisons of $\mathrm{Cu}-\mathrm{Au}-\mathrm{Fe}( \pm \mathrm{Co}, \mathrm{REE})$ deposits with other ore types}

Comparison of the geochemistry of $\mathrm{Cu}-\mathrm{Au}-\mathrm{Fe}( \pm \mathrm{Co}, \mathrm{REE})$ ores attributed as IOCG deposits in the OSNACA data set reveals that, for the CGI-Co, CGI-REE and CGI-Co-REE subgroups, $\mathrm{Co}+\mathrm{Ni}+\mathrm{Bi}+\mathrm{Se}+\mathrm{Te}$ and/or $\mathrm{U}+\mathrm{REE}$ are enriched relative to porphyry $(\mathrm{Cu} \pm \mathrm{Au}, \mathrm{Mo})$, skarn deposits of various types ( $\mathrm{Cu}, \mathrm{Fe}, \mathrm{Au}, \mathrm{W}, \mathrm{Sn})$, and granite-related greisen $(\mathrm{Sn}, \mathrm{W}, \mathrm{Mo}, \mathrm{Bi})$ and pegmatite $(\mathrm{Nb}$, Ta, Li) deposits (Fig. 14). These differences are also clearly evident when only La and Co are plotted as key representatives of the REE and $\mathrm{Co}+\mathrm{Ni}+\mathrm{Bi}+\mathrm{Se}+\mathrm{Te}$ element groups (Fig. 15). The porphyry, skarn and granite-related groups of deposits, widely agreed to be of intrusion-related magmatic-hydrothermal origin, have $\mathrm{Co}+\mathrm{Ni}+\mathrm{U}+\mathrm{La}$ (total ppm) values of generally less than 100 for samples with $\mathrm{Cu}>1000 \mathrm{ppm}$, whereas the IOCG-attributed deposits mostly have $\mathrm{Co}+\mathrm{Ni}+\mathrm{U}+\mathrm{La}$ (total ppm) values greater than 100 for $\mathrm{Cu}>1000 \mathrm{ppm}$ (Fig. 10). In the La versus Co diagram the nominal boundaries of $100 \mathrm{ppm}$ La and $100 \mathrm{ppm}$ Co used for subdivision of the $\mathrm{Cu}-\mathrm{Au}-\mathrm{Fe}( \pm \mathrm{Co}$, REE) deposits appear to also effectively demarcate the fields of the porphyry and skarn deposits (Fig. 15). Notably, the low Co, La and U contents of most of the Andean Cu-Au-Fe ( $\pm \mathrm{Co}, \mathrm{REE}$ ) ore samples (except some Mantoverde samples) match the low values of porphyry and skarn deposits, which are also mostly located within magmatic arc settings (Sillitoe, 2010).

Comparison of the $\mathrm{Cu}-\mathrm{Au}-\mathrm{Fe}( \pm \mathrm{Co}, \mathrm{REE})$ deposits with volcanic-hosted massive sulfide (VHMS) $\mathrm{Zn}-\mathrm{Pb}-\mathrm{Cu}$ deposits and sediment-hosted stratiform $\mathrm{Cu}$ deposits shows considerable overlap in Co contents but significant differences in REE and U, with few exceptions (Fig. 16). There are also major differences in the geological settings and structural controls of these three deposit types, which should serve to distinguish their affiliations.

In summary, with the exception of the Andean $\mathrm{Cu}-\mathrm{Au}-\mathrm{Fe}$ deposits, most IOCG-attributed ores in the OSNACA data set are dissimilar to magmatic-hydrothermal deposit types, in terms of the key element groups $\mathrm{Co}+\mathrm{Ni}+\mathrm{Bi}+\mathrm{Se}+\mathrm{Te}$ and $\mathrm{REE}+\mathrm{U}(\mathrm{Mo}, \mathrm{F}, \mathrm{Ba})$. Conversely, some of the $\mathrm{Cu}-\mathrm{Au}-\mathrm{Fe}( \pm \mathrm{Co}$, REE) ores (particularly the CGI-Co deposits) show some geochemical similarities to ore types that are generally accepted to have formed via leaching of host rocks by hydrothermal fluids (e.g. by evolved seawater for VHMS deposits, or basinal/diagenetic brines for sediment-hosted stratiform $\mathrm{Cu}$ deposits). Clearly there are many other geological, mineralogical and geochemical features that help to distinguish the various ore types, and yet these simple comparisons of selected chalcophile-siderophile elements, LILE and HFSE reveal some consistent traits for the $\mathrm{Cu}-\mathrm{Au}-\mathrm{Fe}$ ( \pm Co, REE) deposits. The possible reasons for these geochemical similarities and differences are discussed in the accompanying paper (Skirrow, in prep.), where they are suggested to relate to the relative partitioning of compatible and incompatible elements between hydrous fluid, silicate melts, and sulfide melt, and the relative stabilities of the metal complexes and mineral solubilities in hydrothermal fluids. Indeed, the elements $\mathrm{Co}, \mathrm{Ni}, \mathrm{U}$ and La have been chosen as discriminators 
mainly because of their contrasting behaviours in magmatic and hydrothermal fluid-silicatesulfide melt systems. It should be noted, however, that the oxidation states (or other geochemical parameters) of the observed ore-related hydrothermal mineral assemblages do not necessarily represent the initial oxidation states (or other hydrothermal conditions) of the fluids transporting the various ore and minor elements.

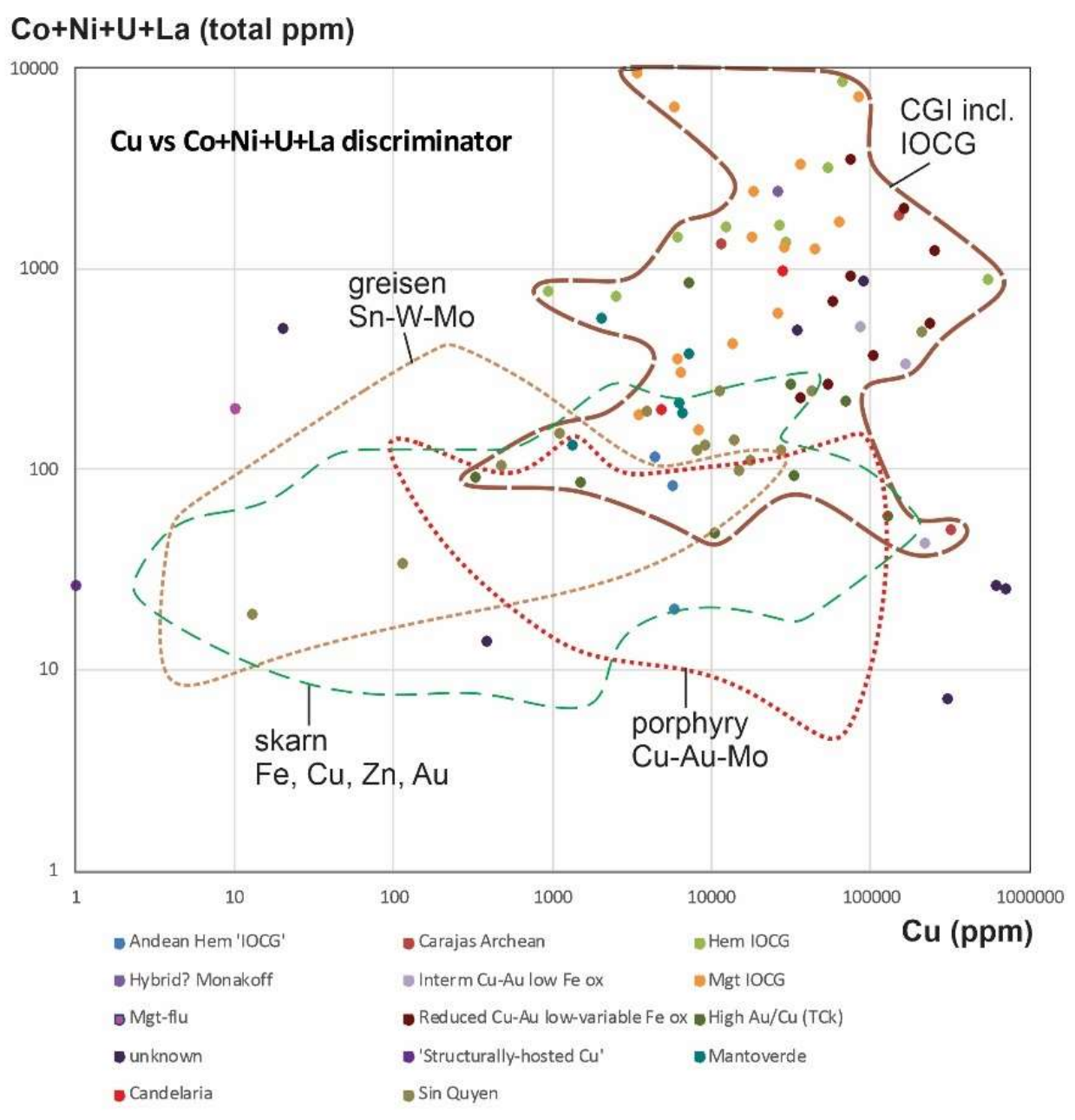

Figure 14. Copper versus $\mathrm{Co}+\mathrm{Ni}+\mathrm{U}+\mathrm{La}$ (in ppm) discriminator diagram comparing $\mathrm{Cu}-\mathrm{Au}-\mathrm{Fe}$ ( $\pm \mathrm{Co}$, REE) including IOCG deposits with fields for intrusion-related magmatic-hydrothermal deposits (porphyry Cu$\mathrm{Au}-\mathrm{Mo}$, skarn Fe $\mathrm{Cu} \mathrm{Zn} \mathrm{Au}$, and greisen Sn-W-Mo). The subtypes of $\mathrm{Cu}-\mathrm{Au}-\mathrm{Fe}$ ( $\pm \mathrm{Co}$, REE) deposits listed in the legend are based on mineralogical subdivisions shown in Figure 7. Data from the OSNACA database (Brauhart \& Hagemann, 2020) with additional data for Mantoverde (Chile, Rieger et al., 2010), Candelaria, Carola and Socavon Rampa (Chile, Marschik \& Fontboté, 2001); and Sin Quyen (Vietnam, Gas'kov et al., 2012). 


\section{Co $\mathrm{Cu}-\mathrm{Au}-\mathrm{Fe}$ (Co, REE), porphyry \& skarn deposits}

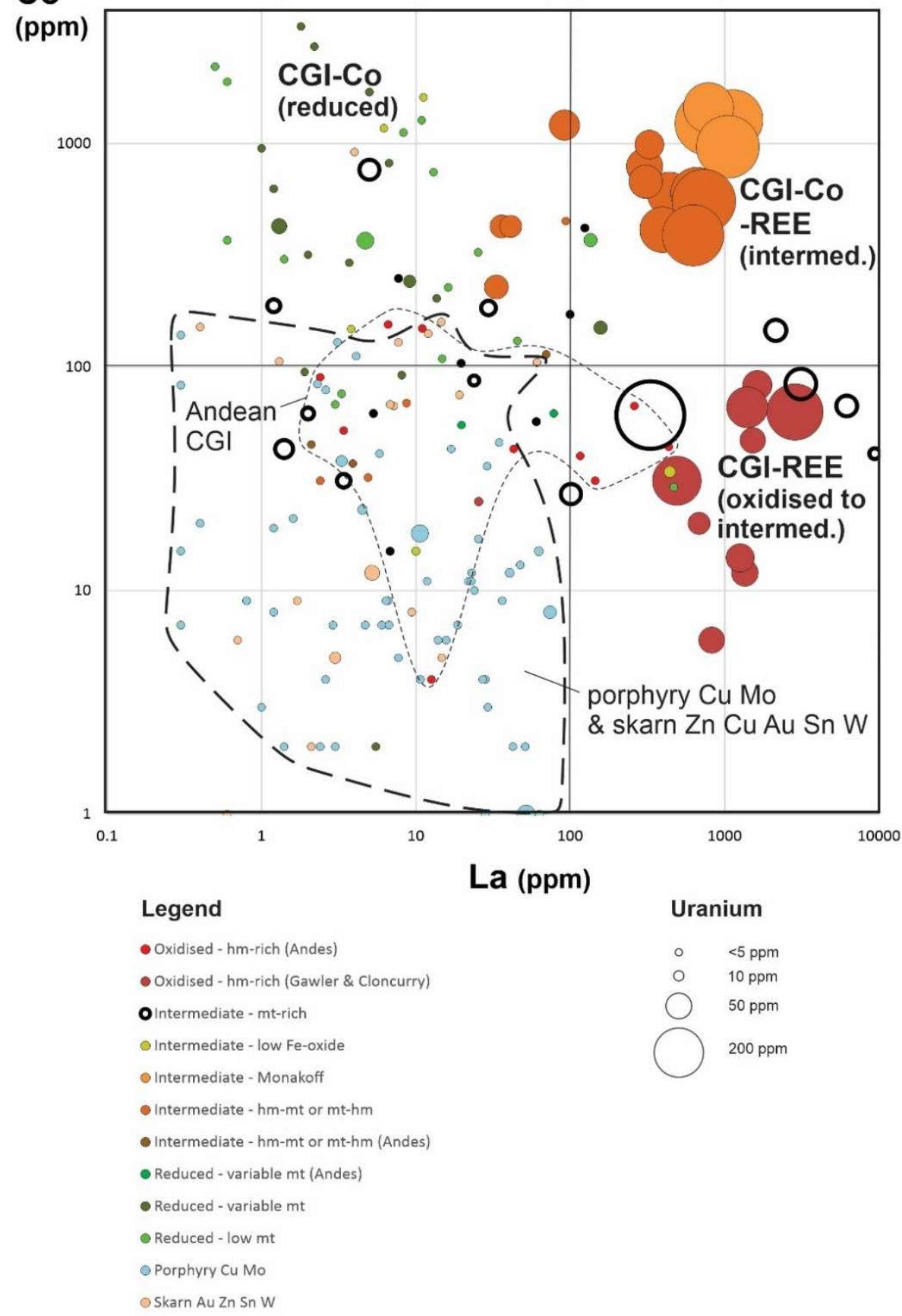

Figure 15. La (ppm) versus Co (ppm) with $\mathrm{U}$ (symbol size) discrimination diagram for $\mathrm{Cu}-\mathrm{Au}-\mathrm{Fe}( \pm \mathrm{Co}$, REE) deposits (CGI-Co, CGI-REE, etc) compared to porphyry $\mathrm{Cu}$, porphyry Mo, and various types of skarn deposits $(\mathrm{Au}, \mathrm{Cu}, \mathrm{Zn}, \mathrm{Sn}, \mathrm{W})$, based on OSNACA ore geochemical data (Brauhart \& Hagemann, 2020). Other details and sources as for Figure 13. 


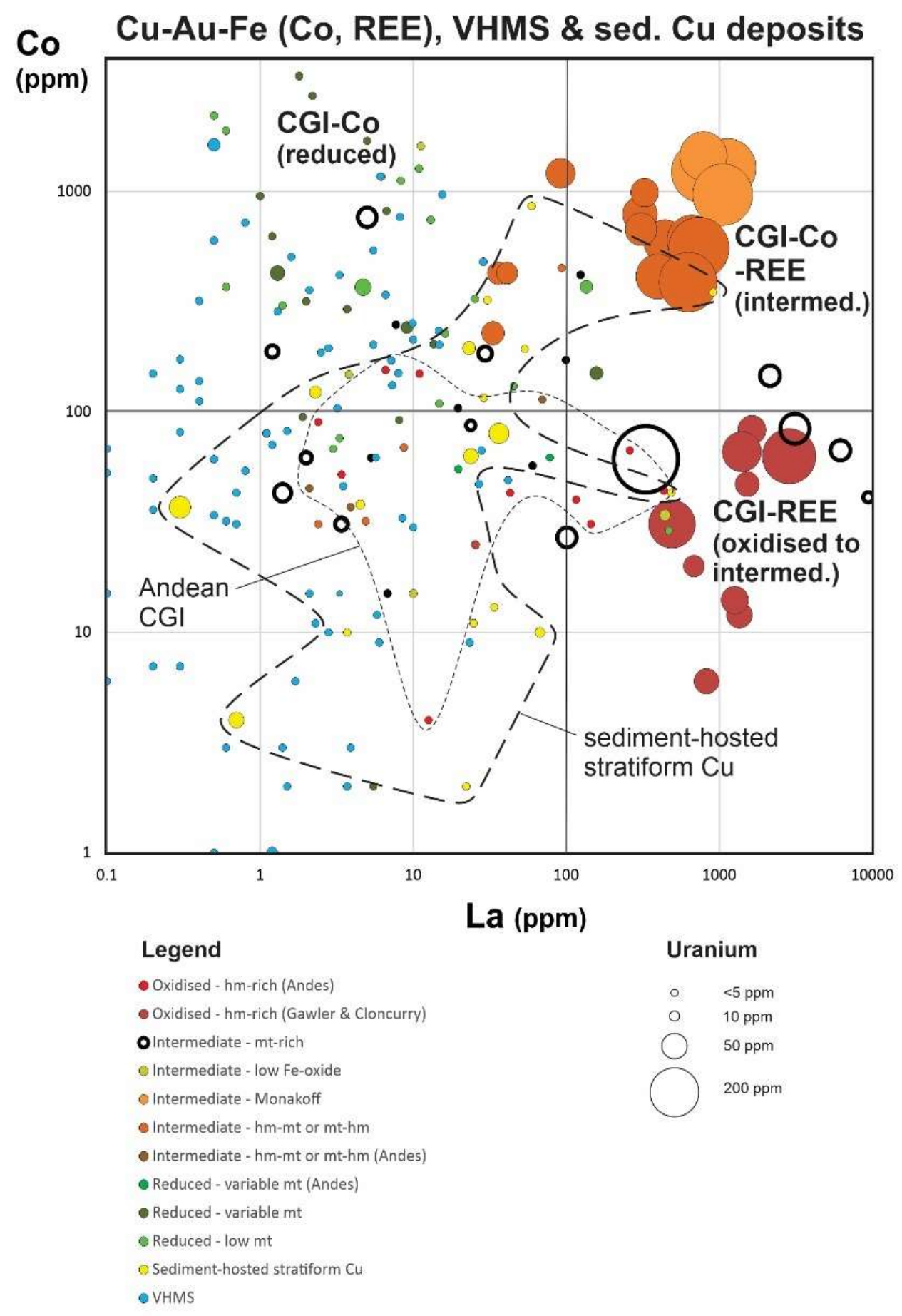

Figure 16. La (ppm) versus Co (ppm) with $\mathrm{U}$ (symbol size) discrimination diagram for $\mathrm{Cu}-\mathrm{Au}-\mathrm{Fe}( \pm \mathrm{Co}, \mathrm{REE})$ deposits (CGI-Co, CGI-REE, etc) compared to porphyry $\mathrm{Cu}$, porphyry Mo, and various types of skarn deposits $(\mathrm{Au}, \mathrm{Cu}, \mathrm{Zn}, \mathrm{Sn}, \mathrm{W})$, based on OSNACA ore geochemical data (Brauhart \& Hagemann, 2020). Other details and sources as for Figure 13. 


\section{Discussion}

\subsection{Relationships between $\mathrm{Cu}-\mathrm{Au}-\mathrm{Fe}( \pm \mathrm{Co}, \mathrm{REE})$ and IOA deposits}

The relationships between IOCG and IOA deposits have been much debated since the 1980s and 1990s. The availability of considerable new data since that time permits some new constraints to be used in addressing this issue. Firstly, among the world's major orogenic-related and arc-hosted $\mathrm{Cu}-\mathrm{Au}-\mathrm{Fe}( \pm \mathrm{Co}, \mathrm{REE})$ provinces, large IOA deposits of Kiruna type are present only in the Kiruna district itself, and in the Chilean Iron Belt, although large magnetite-rich \pm minor apatite hydrothermal bodies and/or Fe-oxide-rich alteration lacking significant $\mathrm{Cu}$-Au mineralisation are present in many of the other major $\mathrm{Cu}-\mathrm{Au}-\mathrm{Fe}( \pm \mathrm{Co}, \mathrm{REE})$ provinces. Available geochronological constraints for the Kiruna/Norbotten district and Chilean Iron Belt indicate that the formation of the large IOA deposits preceded the main $\mathrm{Cu}-\mathrm{Au}-\mathrm{Fe}( \pm \mathrm{Co}, \mathrm{REE})$ mineralisation events by $>10-15$ m.y (see review in the Supplementary Information). Moreover, the IOA deposits in both of these provinces contain very low $\mathrm{Cu}-\mathrm{Au}$ contents, although they generally contain minor pyrite and may host trace chalcopyrite. In rare cases where the IOA deposits contain small $\mathrm{Cu}(-\mathrm{Au})$ resources the textural and structural relationships indicate that the main $\mathrm{Cu}(-\mathrm{Au})$ mineralisation overprints the IOA deposit (e.g. Cerro Negro Norte, Chile, Salazar et al., 2020), consistent with the geochronological data. Conversely, the magnetite-rich paragenetically early stages in the main $\mathrm{Cu}-\mathrm{Au}-\mathrm{Fe}( \pm \mathrm{Co}, \mathrm{REE})$ deposits in the Andean provinces (Chile and Peru) and Kiruna/Norbotten district are not known to be apatite-rich, nor do they contain the coarse-grained (pegmatitic) magnetite-apatite-amphibole intergrowths that are typical of parts of many IOA deposits in both regions.

Apatite-bearing magnetite-rich alteration is indeed present in some of the other orogenic-related and arc-hosted $\mathrm{Cu}-\mathrm{Au}-\mathrm{Fe}( \pm \mathrm{Co}, \mathrm{REE})$ provinces but, as in the Kiruna and Andean provinces, it is paragenetically earlier than, and temporally distinguishable from, the $\mathrm{Cu}-\mathrm{Au}$ mineralisation where data are available. For example, in the post-orogenic Olympic $\mathrm{Cu}-\mathrm{Au}$ province in the Gawler Craton magnetite-rich alteration with locally abundant apatite at the Acropolis prospect formed $\sim 4$ m.y. earlier than the major Cu-U-Au mineralisation event at the Olympic Dam deposit (Cherry et al., 2018, Courtney-Davies et al., 2019; McPhie et al., 2020; see also review in the Supplementary Information). Moreover, the magnetite alteration at Acropolis and elsewhere in the Olympic Dam district is associated with hydrothermal K-feldspar and carbonate as well as actinolite, pyrite and quartz (Oreskes and Einaudi, 1990, 1992; Bastrakov et al., 2007; Cherry et al., 2018). This $\mathrm{K}^{-\mathrm{CO}_{2}}$-Ca-rich character is different to the typically Ca-Na-rich compositions of alteration minerals in and around most magnetite-rich IOA deposits such as those in the Kiruna district, Chilean Iron Belt, southeast Missouri (USA) and the Bafq district of Iran (e.g. Oyarzun et al., 2003; Daliran, 2010; Zhou et al., 2013; Martinsson et al., 2016; Day et al., 2016; Bonyadi and Sadeghi, 2020). Nevertheless, potassic alteration is present in some peripheral and/or upper alteration zones of some IOA deposits, where it is generally represented by K-feldspar accompanied by hematite (e.g. Kiruna district, Martinsson et al., 2016; southeast Missouri, Day et al., 2016) or by phlogopite \pm K-feldspar (e.g. Middle-Lower Yangtze Belt, China, Zhou et al., 2013). Neither of these assemblages have been reported in the $\mathrm{Cu}-\mathrm{Au}-\mathrm{Fe}( \pm \mathrm{Co}, \mathrm{REE})$ deposits considered in the present review of 11 metallogenic provinces globally.

In other syn-orogenic $\mathrm{Cu}-\mathrm{Au}-\mathrm{Fe}( \pm \mathrm{Co}, \mathrm{REE})$ provinces with paragenetically early magnetite-rich alteration, apatite is either absent/not described (Guelb Moghrein, Tennant Creek, Cloncurry, Khetri) or is only rarely abundant with magnetite alteration (e.g. Sequeirinho orebody of Sossego 
deposit, Carajás province, Monteiro et al., 2008). Biotite and carbonate commonly accompany the early magnetite-rich alteration in many orogenic $\mathrm{Cu}-\mathrm{Au}-\mathrm{Fe}( \pm \mathrm{Co}$, REE) provinces, but these minerals are rarely present in significant modal amounts in the major IOA deposits in the Kiruna, southeast Missouri, Bafq, Middle-Lower Yangtze Belt and the Chilean Iron Belt IOA provinces. A further example of large hydrothermal magnetite bodies in syn-orogenic $\mathrm{Cu}-\mathrm{Au}-\mathrm{Fe}( \pm \mathrm{Co}, \mathrm{REE})$ provinces is the Lightning Creek sill complex in the Cloncurry district. Here, the albite-magnetitequartz \pm diopside mineralogy and spherulitic textures of the magnetite-rich bodies within the monzodioritic intrusion (Perring et al., 2000) are different to the variably apatite-amphibolealbite \pm K-feldspar \pm pyrite-bearing mineralogy and massive to pegmatoidal textures that are typical of magnetite and/or hematite-rich Kiruna type IOA deposits.

Except for the Kiruna region and Chilean Iron Belt, other major IOA provinces including southeast Missouri, Bafq, and the Middle-Lower Yangtze Belt are not known to contain significant $\mathrm{Cu}-\mathrm{Au}-\mathrm{Fe}$ ( \pm Co, REE) deposits of the types described herein (orogenic-related and arc-hosted) but in some cases host porphyry $\mathrm{Cu}(-\mathrm{Au})$ and/or intrusion-related skarn $\mathrm{Fe}$ and/or $\mathrm{Cu}$ and/or $\mathrm{Au}$ deposits (e.g. Middle-Lower Yangtze Belt, Zhou et al., 2013; Sun et al., 2017). The Boss Cu deposit is the only known significant $\mathrm{Cu}$ resource in the southeast Missouri IOA district (40 Mt @ $0.83 \% \mathrm{Cu}$ ), which has been described as an IOCG deposit and lacks significant apatite with the early-stage Feoxides (Day et al., 2016). Iron and Cu sulfides overprinted the Fe-oxides and have high $\delta^{34} \mathrm{~S}$ values indicating a sulfur source likely external to the spatially associated igneous rocks, possibly related to input of basinal brines (Shelton et al., 1995). Thus it seems likely that in this rare case of significant $\mathrm{Cu}$ mineralisation in an IOA province (other than Kiruna and the Chilean Iron Belt, noted above), the introduction of $\mathrm{Cu}$ was not directly related to the formation of the host Fe-oxiderich body, which is similar to other IOA deposits in the district that are generally considered to be of magmatic-hydrothermal origin (e.g. Johnson et al., 2016).

Finally, the major IOA provinces that lack significant and later $\mathrm{Cu}-\mathrm{Au}-\mathrm{Fe}( \pm \mathrm{Co}, \mathrm{REE})$ deposits also did not experience major orogenic events immediately before, during or soon after IOA deposit formation (Bafq - Daliran, 2010; Middle-Lower Yangtze Belt - Zhou et al., 2013; southeast Missouri - Day et al., 2016). This observation is a further point of difference between the evolution of the orogenic-related $\mathrm{Cu}-\mathrm{Au}-\mathrm{Fe}( \pm \mathrm{Co}, \mathrm{REE})$ and IOA provinces.

In summary, available geological and geochronological information strongly points to different timing, tectonic settings, hydrothermal evolution and probably origins of formation of the orogenic-related $\mathrm{Cu}-\mathrm{Au}-\mathrm{Fe}( \pm \mathrm{Co}, \mathrm{REE})$ deposits compared to IOA deposits. The most productive settings for orogenic-related $\mathrm{Cu}-\mathrm{Au}-\mathrm{Fe}( \pm \mathrm{Co}, \mathrm{REE})$ mineralisation appear to be those where inversion of (extended) continental margin basins occurred inboard of prior magmatic arcs, coincident with syn- to post-orogenic magmatism. In contrast, the settings of most large IOA deposits were continental margin magmatic arcs undergoing extension/transtension. Although this same broad setting was shared by the arc-hosted $\mathrm{Cu}-\mathrm{Au}-\mathrm{Fe}( \pm \mathrm{Co}, \mathrm{REE})$ deposits in the Andes, available data indicate that the major IOA deposits formed some millions of years earlier than the $\mathrm{Cu}-\mathrm{Au}-\mathrm{Fe}( \pm \mathrm{Co}, \mathrm{REE})$ deposits. 


\subsection{Classification of $\mathrm{Cu}-\mathrm{Au}-\mathrm{Fe}( \pm \mathrm{Co}, \mathrm{REE})$ deposits in orogenic-related and arc-hosted settings}

The results of the present review of geological and tectonic settings, alteration-mineralisation mineralogy and ore geochemistry of $\mathrm{Cu}-\mathrm{Au}-\mathrm{Fe}( \pm \mathrm{Co}$, REE) deposits are integrated within the classification scheme shown simplified in Figures 17 and 18, and in detail in Table 2. A broader classification scheme including other types of hydrothermal $\mathrm{Cu} \pm \mathrm{Au}$ and/or Fe deposits is presented in Table 3. Whereas there are some similarities between this scheme and the previous classifications of Hitzman et al. (1992), Hitzman (2000), Williams et al. (2005), Williams (2010), Groves et al. (2010) and Barton (2013) there are some significant differences, as follows.

First, this classification distinguishes three tectonic settings: syn- and post-orogenic and archosted, which only partly correlate with any previous proposals of settings. The syn-tectonic settings of many of the $\mathrm{Cu}-\mathrm{Au}-\mathrm{Fe}( \pm \mathrm{Co}, \mathrm{REE})$ deposits have been especially under-emphasised previously, with far more focus on 'anorogenic' settings. In the present scheme none of the proposed settings are 'anorogenic'; instead a post-orogenic setting is proposed that is intimately linked to the preceding orogenic processes in the same terranes.

Second, this scheme distinguishes $\mathrm{Cu}-\mathrm{Au}-\mathrm{Fe}( \pm \mathrm{Co}, \mathrm{REE})$ deposits from porphyry $\mathrm{Cu}(-\mathrm{Au})$, skarn $\mathrm{Fe}-\mathrm{Cu}-\mathrm{Au}$, and IOA deposits, although it is recognised that some features of the geology, mineralogy and geochemistry may be shared between these deposit types. In particular, several of the previous classifications consider IOA deposits as 'end-members' within a broad family of iron oxide-associated deposits, whereas it is proposed herein that they may be close relatives of the arc-hosted Andean-type $\mathrm{Cu}-\mathrm{Au}-\mathrm{Fe}$ but are of fundamentally different origin to the orogenicrelated $\mathrm{Cu}-\mathrm{Au}-\mathrm{Fe}( \pm \mathrm{Co}, \mathrm{REE})$ deposits.

Finally, mineralogical and geochemical subtypes of the $\mathrm{Cu}-\mathrm{Au}-\mathrm{Fe}( \pm \mathrm{Co}$, REE) deposits in particular geotectonic settings are proposed in the classification scheme, which have been only partly recognised or were unrecognised previously. For example deposits of the CGI-Co subtype are characterised by correlations between reduced ore-related hydrothermal mineral assemblages and elevated levels of $\mathrm{Co}, \mathrm{Ni}, \mathrm{Bi}$, Se and/or Te (and low $\mathrm{U}$ and $\mathrm{REE}$ ), and occur within the syn-orogenic setting (Fig. 17). Also, the classification of low-Fe-oxide $\mathrm{Cu}-\mathrm{Au}$ deposits partly including the ISCG deposits of Haynes (2000)also differs. Williams (2010) included such deposits within a family of iron oxide $\mathrm{Cu}-\mathrm{Au} \pm \mathrm{U}$ deposits, whereas here they are included within the $\mathrm{Cu}$ $\mathrm{Au}-\mathrm{Fe}$ ( $\pm \mathrm{Co}, \mathrm{REE}$ ) family but are distinguished from iron-oxide-rich $\mathrm{Cu}-\mathrm{Au}$ deposits. It is recommended that the term IOCG is reserved for CGI deposits with abundant Fe-oxides or, preferably, the specific deposit subtype is identified (e.g. syn-orogenic reduced CGI-Co, or postorogenic oxidised CGI-REE). 


\section{Deposit classification in Cu-Au-Fe (CGI) family including IOCG and ISCG}

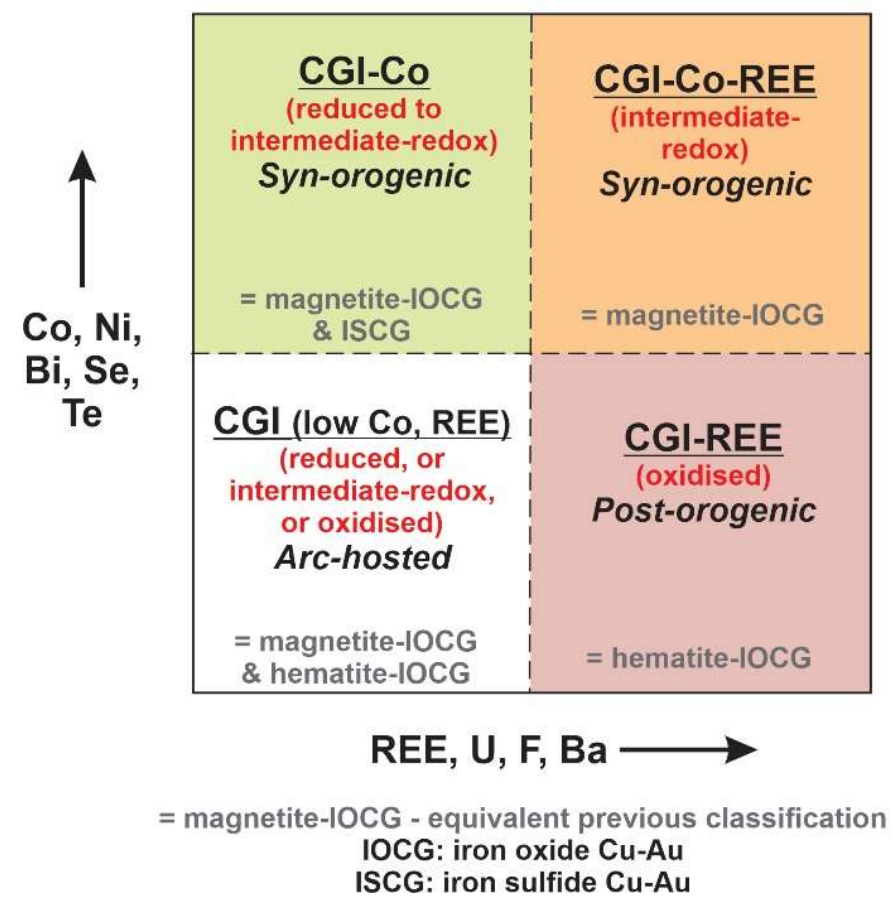

Figure 17. Classification scheme with ore geochemical axes for subtypes of deposits in the $\mathrm{Cu}-\mathrm{Au}-\mathrm{Fe}$ (CGI) family including IOCG and ISCG deposits, compared to nomenclature in the scheme of Williams (2010) (grey text). Note the combined use of ore geochemical, mineralogy-based redox, and geotectonic setting attributes in the proposed scheme.

\section{Deposit classification in Cu-Au-Fe (CGI) family}

(excluding arc-hosted low-Co-REE CGI deposits)

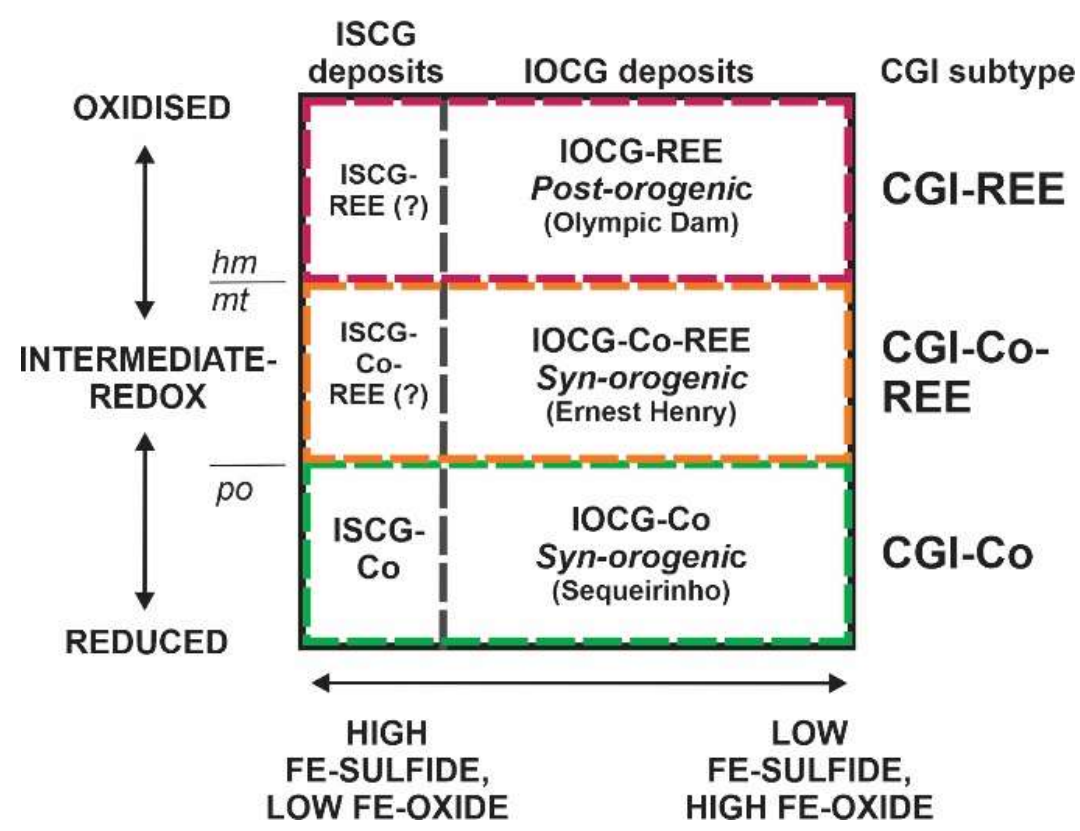

Figure 18. Classification scheme with redox and sulfide/oxide ratio axes for subtypes of deposits in the Cu$\mathrm{Au}-\mathrm{Fe}$ (CGI) family including IOCG and ISCG deposits, with type examples (Olympic Dam, Ernest Henry, Sequeirinho ore body of the Sossego deposit). The boundary between IOCG and ISCG deposits is nominally set where the abundances (by volume) of oxides and Fe sulfides are equal. Some ISCG deposit types have not been documented but are predicted to exist (shown with '?' in Fig. 18). 
Table 2. Classification and key features of syn-orogenic, post-orogenic and arc-hosted $\mathrm{Cu}-\mathrm{Au}-\mathrm{Fe}( \pm$ Co, REE) deposits including IOCG deposits, compared with IOA deposits.

\begin{tabular}{|c|c|c|c|c|c|c|}
\hline $\begin{array}{l}\text { Deposit } \\
\text { type }\end{array}$ & $\begin{array}{l}\text { Deposit } \\
\text { redox or } \\
\text { other } \\
\text { subtype }\end{array}$ & $\begin{array}{l}\text { Timing, } \\
\text { tectonic } \\
\text { setting, } \\
\text { deformation }\end{array}$ & $\begin{array}{l}\text { Ore } \\
\text { geochem. } \\
\text { (subtype) }\end{array}$ & $\begin{array}{l}\text { Dominant } \\
\text { Fe ox \& Fe- } \\
\text { Cu sulfides }\end{array}$ & $\begin{array}{l}\text { Alteration/ } \\
\text { metasomatism }\end{array}$ & Example deposits \\
\hline \multirow{3}{*}{$\begin{array}{l}\text { Syn- } \\
\text { orogenic Cu- } \\
\mathrm{Au}-\mathrm{Fe}( \pm \mathrm{Co} \text {, } \\
\mathrm{REE})\end{array}$} & $\begin{array}{l}\text { Reduced to } \\
\text { intermediate- } \\
\text { redox IOCG } \\
\text { to ISCG } \\
\text { spectrum }\end{array}$ & $\begin{array}{l}\text { syn-orogenic, } \\
\text { syn-tectonic, } \\
\text { brittle-ductile }\end{array}$ & $\begin{array}{l}\mathrm{Cu}, \mathrm{Au}, \mathrm{Co}, \\
\mathrm{Ni} \text {; some } \\
\text { have minor } \\
\mathrm{Zn}, \mathrm{Pb}, \mathrm{Bi}, \mathrm{Se} \text {, } \\
\mathrm{Te}, \mathrm{As} \\
\text { (CGI-Co) }\end{array}$ & $\begin{array}{l}\text { mt, po, py, } \\
\text { cpy }\end{array}$ & $\begin{array}{l}\text { early } \mathrm{Na} \pm \mathrm{Ca} \\
\text { (alb, scp, act); } \\
\text { mid Ca-Fe } \\
\text { (amph, mt, dp, } \\
\text { gt, all, ap); } \\
\text { late } \mathrm{Fe}-\mathrm{K}(\mathrm{mt}, \\
\text { bt, } \mathrm{Kfs}) \text { with } \\
\mathrm{Cu}-\mathrm{Au} \& \\
\text { volatiles }\left(\mathrm{CO}_{2} \text {, }\right. \\
\text { P, B) }\end{array}$ & $\begin{array}{l}\text { IOCG: Osborne, } \\
\text { West Peko, some } \\
\text { Carajás (Sequeir.), } \\
\text { some Kangdian } \\
\text { (Dahongshan, Lala), } \\
\text { some Khetri, some } \\
\text { GBMZ (NICO), } \\
\text { ISCG: Guelb } \\
\text { Moghrein, Eloise, } \\
\text { Greenmount, Mt } \\
\text { Dore, parts Mt } \\
\text { Elliott }\end{array}$ \\
\hline & $\begin{array}{l}\text { Intermediate- } \\
\text { redox to } \\
\text { oxidised } \\
\text { IOCG to ISCG } \\
\text { spectrum }\end{array}$ & $\begin{array}{l}\text { syn-orogenic, } \\
\text { syn-tectonic, } \\
\text { brittle-ductile }\end{array}$ & $\begin{array}{l}\mathrm{Cu}, \mathrm{Au} \text { with } \\
\text { (Co, Ni) or } \\
\text { (Mo, F, REE, } \\
\text { U, Ba) or } \\
\text { both (EH, } \\
\text { Monakoff, } \\
\text { E1, Salobo) } \\
\text { (CGI-Co- } \\
\text { REE) }\end{array}$ & $\begin{array}{l}\text { mt, hm, py, } \\
\text { cpy, bn }\end{array}$ & $\begin{array}{l}\text { early } \mathrm{Na} \pm \mathrm{Ca} \\
(\mathrm{alb}, \mathrm{scp}, \mathrm{act}) \\
\text { mid } \mathrm{Ca}-\mathrm{Fe} \\
(\mathrm{amph}, \mathrm{mt}, \mathrm{dp} \text {, } \\
\text { gt, all, ap); } \\
\text { late } \mathrm{Fe}-\mathrm{K}(\mathrm{mt} \text {, } \\
\text { bt, Kfs) with } \\
\mathrm{Cu}-\mathrm{Au} \& \\
\text { volatiles }\left(\mathrm{CO}_{2} \text {, }\right. \\
\left.\mathrm{P}, \mathrm{F}, \mathrm{B}, \mathrm{SO}_{4}\right) \\
\text { (except TCk) }\end{array}$ & $\begin{array}{l}\text { IOCG: Ernest } \\
\text { Henry; E1, } \\
\text { Monakoff (late F, } \\
\text { Ba, Cu?); SWAN?, } \\
\text { Sin Quyen?, Salobo, } \\
\text { Rakkurijarvi; some } \\
\text { Tennant Creek; } \\
\text { ISCG: some Kiruna } \\
\text { CuAu; some Khetri } \\
\text { CuAu (SSC); } \\
\text { Hongnipo? } \\
\text { (Kangdian) }\end{array}$ \\
\hline & $\begin{array}{l}\text { Oxidised } \\
\text { IOCG to ISCG } \\
\text { spectrum }\end{array}$ & $\begin{array}{l}\text { syn-orogenic, } \\
\text { syn-tectonic, } \\
\text { brittle-ductile } \\
\text { to brittle; some } \\
\text { may be late- } \\
\text { orogenic or } \\
\text { post- } \\
\text { orogenic(?) }\end{array}$ & $\begin{array}{l}\mathrm{Cu}, \mathrm{Au}, \mathrm{REE}, \\
\mathrm{U}, \mathrm{F}, \mathrm{Ba} \\
\text { (some CGI- } \\
\text { Co-REE) }\end{array}$ & $\begin{array}{l}\text { hm, py, cpy, } \\
\text { bn, cc }\end{array}$ & $\begin{array}{l}\text { late } \mathrm{Fe}-\mathrm{K}(\mathrm{hm}, \\
\text { mv, chl) with } \\
\mathrm{Cu}-\mathrm{Au} \& \\
\text { volatiles }\left(\mathrm{CO}_{2},\right. \\
\left.\mathrm{P}, \mathrm{F}, \mathrm{SO}_{4}\right)\end{array}$ & $\begin{array}{l}\text { IOCG: Starra (hm- } \\
\text { Ba-F-Au-bn zones); } \\
\text { Gecko K44 upper, \& } \\
\text { Eldorado (but lack } \\
\text { Co, REE, U, F or Ba) }\end{array}$ \\
\hline \multirow{2}{*}{$\begin{array}{l}\text { Post- } \\
\text { orogenic Cu- } \\
\text { Au-Fe (REE) }\end{array}$} & $\begin{array}{l}\text { Intermediate- } \\
\text { redox }\end{array}$ & $\begin{array}{l}\text { post-orogenic, } \\
\text { switch from } \\
\text { compressional } \\
\text { to extensional, } \\
\text { brittle } \\
\text { deformation }\end{array}$ & $\begin{array}{l}\text { Minor P (ap), } \\
\pm \mathrm{REE}, \pm \mathrm{Cu}\end{array}$ & $\begin{array}{l}\text { mt, py, minor } \\
\text { cpy }\end{array}$ & $\begin{array}{l}\text { early } \mathrm{Na} \pm \mathrm{Ca} \\
\text { (alb, scp, act, } \\
\text { dp); } \\
\text { mid Fe-K-Na-Ca } \\
\text { (mt, bt, alb, } \\
\text { act); } \\
\text { or mid Fe-K-Ca } \\
\text { (mt, Kfs, act, ap, } \\
\text { carb, qtz) }\end{array}$ & $\begin{array}{l}\text { IOCG alteration: } \\
\text { Acropolis, Titan, } \\
\text { Murdie; } \\
\text { IOCG deposits: } \\
\text { Kalkaroo, Wallaroo }\end{array}$ \\
\hline & $\begin{array}{l}\text { Oxidised } \\
\text { IOCG to ISCG } \\
\text { spectrum }\end{array}$ & $\begin{array}{l}\text { post-orogenic, } \\
\text { switch from } \\
\text { compressional } \\
\text { to extensional, } \\
\text { brittle } \\
\text { deformation }\end{array}$ & $\begin{array}{l}\mathrm{Cu}, \mathrm{Au}, \mathrm{Ag}, \\
\mathrm{REE}, \mathrm{U}, \mathrm{F}, \mathrm{Ba}, \\
\pm \mathrm{Mo} \\
\text { (CGI-REE) }\end{array}$ & $\begin{array}{l}\text { hm, py, cpy, } \\
\text { bn, cc; minor } \\
\text { or no mt }\end{array}$ & $\begin{array}{l}\text { mid Fe (-P- } \\
\left.\mathrm{CO}_{2}\right)(\mathrm{mt}, \text { sid, } \\
\text { ap); } \\
\text { late } \mathrm{Fe} \text {-volatiles } \\
(-\mathrm{K})(\mathrm{hm}, \mathrm{ser} \\
\text { chl, } \mathrm{CO}_{2}, \mathrm{P}, \mathrm{F} \text {, } \\
\left.\mathrm{SO}_{4}\right) \text { with Cu- } \\
\mathrm{Au}-\mathrm{REE}-\mathrm{U}\end{array}$ & $\begin{array}{l}\text { IOCG: Olympic } \\
\text { Dam, Prominent } \\
\text { Hill, Wirrda Well, } \\
\text { Carrapateena, Sue } \\
\text { Dianne?, North } \\
\text { Portia; } \\
\text { ISCG \& Au: } \\
\text { Moonta?, White } \\
\text { Dam Au-Mo }\end{array}$ \\
\hline $\begin{array}{l}\text { Arc- or back- } \\
\text { arc-hosted } \\
\text { Cu-Au-Fe }\end{array}$ & $\begin{array}{l}\text { Reduced to } \\
\text { intermediate- } \\
\text { redox } \\
\text { IOCG }\end{array}$ & $\begin{array}{l}\text { Syn- } \\
\text { subduction; } \\
\text { extension } \\
\text { before } \\
\text { inversion, } \\
\text { mostly brittle } \\
\text { deformation }\end{array}$ & $\begin{array}{l}\mathrm{Cu} \text {, minor } \\
\mathrm{Au}, \\
\text { (generally } \\
\text { low } \mathrm{P}, \mathrm{Co}, \mathrm{Ni} \text {, } \\
\mathrm{REE}, \mathrm{U}, \mathrm{F}, \\
\mathrm{Ba} \text { ) }\end{array}$ & $\begin{array}{l}\text { mt, po, py, } \\
\text { cpy }\end{array}$ & $\begin{array}{l}\text { early Na (alb); } \\
\text { mid Fe-K (mt, } \\
\text { bt, Kfs); } \\
\text { late Ca-Fe-K } \\
\text { (mt, amph, bt, } \\
\text { Kfs) with Cu (- } \\
\mathrm{Au})\end{array}$ & $\begin{array}{l}\text { IOCG: Candelaria, } \\
\text { Raúl-Condestable?, } \\
\text { Marcona? }\end{array}$ \\
\hline
\end{tabular}




\begin{tabular}{|c|c|c|c|c|c|c|}
\hline & $\begin{array}{l}\text { Intermediate- } \\
\text { redox to } \\
\text { oxidised } \\
\text { IOCG to ISCG } \\
\text { spectrum }\end{array}$ & $\begin{array}{l}\text { Syn- } \\
\text { subduction; } \\
\text { extension } \\
\text { before } \\
\text { inversion, } \\
\text { mostly brittle } \\
\text { deformation } \\
\end{array}$ & $\begin{array}{l}\text { Cu, minor } \\
\mathrm{Au}, \mathrm{Ag}, \text { rare } \\
\mathrm{REE}, \mathrm{U} \\
\text { (generally } \\
\text { low } \mathrm{P}, \mathrm{Co}, \mathrm{Ni} \text {, } \\
\mathrm{F}, \mathrm{Ba} \text { ) }\end{array}$ & $\begin{array}{l}\text { hm, mt, py, } \\
\text { cpy, bn, cc }\end{array}$ & $\begin{array}{l}\text { early-mid Fe (- } \\
\mathrm{Na},-\mathrm{K},-\mathrm{Ca})(\mathrm{mt} \text {, } \\
\text { alb, Kfs, amph); } \\
\text { late Fe }\left(-\mathrm{CO}_{2}\right) \\
(\mathrm{hm}, \mathrm{carb}, \mathrm{chl}) \\
\text { with } \mathrm{Cu}(-\mathrm{Au})\end{array}$ & $\begin{array}{l}\text { IOCG: Mantoverde, } \\
\text { Mina Justa? } \\
\text { ISCG?: some } \\
\text { Chilean manto Cu- } \\
\text { Ag } \pm \text { Fe (Punta del } \\
\text { Cobre district, } \\
\text { Mantos Blancos) }\end{array}$ \\
\hline & $\begin{array}{l}\text { Oxidised } \mathrm{Cu} \\
(-\mathrm{Au}) \pm \text { iron } \\
\text { oxides }\end{array}$ & $\begin{array}{l}\text { Syn-subduction, } \\
\text { ?pre- or ?early- } \\
\text { orogenic } \\
\end{array}$ & $\begin{array}{l}\mathrm{Cu}, \mathrm{Ag} \text { (low } \\
\mathrm{Au}, \mathrm{REE}, \mathrm{U} \text { ) }\end{array}$ & $\begin{array}{l}\text { cpy, bn, cc, } \\
\text { py } \pm \text { minor } \\
\text { hm }\end{array}$ & ?? & $\begin{array}{l}\text { ISCG?: some } \\
\text { Chilean mantos (El } \\
\text { Soldado) }\end{array}$ \\
\hline \multirow{2}{*}{$\begin{array}{l}\text { Arc- or back- } \\
\text { arc-hosted } \\
\text { IOA }\end{array}$} & Fe-Ca-P & $\begin{array}{l}\text { Syn-subduction, } \\
\text { extensional / } \\
\text { transtensional, } \\
\text { rifted arc or } \\
\text { back-arc } \\
\end{array}$ & $\begin{array}{l}\mathrm{Ca}, \mathrm{P}, \pm \\
\mathrm{LREE}, \pm \mathrm{F}, \pm \\
\mathrm{S}\end{array}$ & $\begin{array}{l}\text { mt } \pm \text { minor } \\
\text { py, anh, (rare } \\
\text { cpy, no } \mathrm{Au})\end{array}$ & $\begin{array}{l}\text { Fe-Ca-P (mt, ap, } \\
\text { amph, cpx) }\end{array}$ & $\begin{array}{l}\text { Kiruna, MLYB, CIB } \\
\text { (ER, LC, EA, EC, EL), } \\
\text { SEM (PR, LPK), } \\
\text { Bafq }\end{array}$ \\
\hline & Fe-K & $\begin{array}{l}\text { Syn-subduction, } \\
\text { extensional / } \\
\text { transtensional, } \\
\text { rifted arc or } \\
\text { back-arc }\end{array}$ & $\begin{array}{l}\mathrm{K},(\text { low }-\mathrm{P}) \pm \\
\mathrm{S}, \pm \mathrm{F}, \pm \\
\mathrm{LREE}, \mathrm{Ba}, \mathrm{B}, \\
\pm \text { minor } \mathrm{Cu} \\
\text { (lack } \mathrm{U}, \mathrm{Mo} \text { ) }\end{array}$ & $\begin{array}{l}\text { mt, hm } \pm \\
\text { minor py, } \\
\text { anh (rare to } \\
\text { minor Cu, no } \\
\mathrm{Au} \text { ) }\end{array}$ & $\begin{array}{l}\text { Fe-K (mt, hm, } \\
\text { Kfs) }\end{array}$ & $\begin{array}{l}\text { SEM (Boss; PR } \\
\text { late), IM (late), ?MV } \\
\text { (early), Marcona }\end{array}$ \\
\hline
\end{tabular}

Mineral abbreviations: alb - albite, act - actinolite, all - allanite, amph - amphibole, anh anhydrite, ap - apatite, Au - gold, bar - barite, bn - bornite, bt - biotite, carb - carbonate, cc chalcocite, chl - chlorite, cpy - chalcopyrite, cpz - clinopyroxene, dp - diopside, ep - epidote, flu fluorite, gt - garnet, hm - hematite, Kfs - K-feldspar, mt - magnetite, mv - muscovite, po pyrrhotite, py - pyrite, qtz - quartz, REE - REE-rich minerals (carbonate-rich and/or P-rich including monazite and alumino-phosphate-sulfide REE minerals), scp - scapolite, ser - sericite, U - uranium-rich minerals (e.g. uraninite/pitchblende), sid - siderite.

Abbreviations for IOA districts: CIB - Chilean Iron Belt, EA - El Algarrobo, EC - El Colorado, EL - El Laco, ER - El Romeral, IM - Iron Mountain, LC - Los Colorados, LPK - Lower Pilot Knob, MLYB Middle-Lower Yangtze Belt, MV - Mantoverde, PR - Pea Ridge, SEM - southeast Missouri. 
Table 3. Classification scheme of selected $\mathrm{Cu}$ - and/or Fe-rich deposit classes and types, and the place of IOCG deposits within the Cu-Au-Fe \pm \pm Co, REE) deposit family (highlighted in yellow). Genetic class interpretations of the 'hybrid' deposit types are based on discussions in the accompanying contribution (Skirrow, in prep.). Abbreviations: IR - intrusion-related, MH - magmatic-hydrothermal, IOA - iron oxide-apatite, MLYB - Middle-Lower Yangtze Block, SSC - sediment-hosted stratiform Cu.

\begin{tabular}{|c|c|c|c|c|}
\hline Genetic class & Deposit types & $\begin{array}{l}\text { Timing/tectonic } \\
\text { setting }\end{array}$ & $\begin{array}{l}\text { Deposit } \\
\text { subtypes }\end{array}$ & Examples \\
\hline \multirow{3}{*}{$\begin{array}{l}\text { Intrusion- } \\
\text { related } \\
\text { magmatic- } \\
\text { hydrothermal } \\
\text { (IR-MH) }\end{array}$} & $\begin{array}{l}\text { Porphyry } \mathrm{Cu} \\
\text { Porphyry } \mathrm{Cu}-\mathrm{Au} \\
\text { Porphyry Mo }\end{array}$ & Syn-subduction & & Many \\
\hline & $\begin{array}{l}\text { Skarn Fe, Fe }(-\mathrm{Cu}) \\
\text { Skarn } \mathrm{Cu} \\
\text { Skarn } \mathrm{Au}\end{array}$ & Syn-subduction & & $\begin{array}{l}\text { Many } \\
\text { Marcona? }\end{array}$ \\
\hline & $\begin{array}{l}\text { Alkaline-igneous } \\
\text { associated/carbonatite } \\
\mathrm{Cu}, \mathrm{F}, \mathrm{REE}\end{array}$ & anorogenic & & $\begin{array}{l}\text { Palabora } \\
\text { Bayan Obo } \\
\text { Vergenoeg }\end{array}$ \\
\hline $\begin{array}{l}\text { Hybrid: mainly } \\
\text { IR-MH, minor } \\
\text { basinal input }\end{array}$ & IOA & Syn-subduction & & $\begin{array}{l}\text { Kiruna } \\
\text { SE Missouri } \\
\text { Adirondacks } \\
\text { Bafq } \\
\text { MLYB } \\
\end{array}$ \\
\hline $\begin{array}{l}\text { Hybrid: mainly } \\
\text { IR-MH, minor } \\
\text { basinal input }\end{array}$ & $\begin{array}{l}\text { Arc-hosted Andean- } \\
\text { type Cu-Au-Fe } \pm \text { ( Co, } \\
\text { REE) including IOCG }\end{array}$ & $\begin{array}{l}\text { Syn-subduction, } \\
\text { pre- to early- } \\
\text { orogenic }\end{array}$ & $\begin{array}{l}\text { Reduced, } \\
\text { intermediate- } \\
\text { redox \& } \\
\text { oxidised CGI }\end{array}$ & $\begin{array}{l}\text { Candelaria } \\
\text { Mantoverde } \\
\text { Raúl-Condestable } \\
\text { Mina Justa } \\
\end{array}$ \\
\hline \multirow{2}{*}{$\begin{array}{l}\text { Hybrid: } \mathrm{MH} \text { and } \\
\text { basinal inputs }\end{array}$} & \multirow{2}{*}{$\begin{array}{l}\text { Orogenic-related Cu- } \\
\text { Au-Fe ( } \pm \text { Co, REE) } \\
\text { including IOCG \& ISCG } \\
\text { \& some 'SSC' }\end{array}$} & Syn-orogenic & $\begin{array}{l}\text { Reduced CGI- } \\
\text { Co, } \\
\text { intermediate- } \\
\text { redox CGI-Co- } \\
\text { REE \& } \\
\text { oxidised CGI- } \\
\text { Co-REE } \\
\end{array}$ & Many - see * \\
\hline & & Post-orogenic & $\begin{array}{l}\text { Intermediate- } \\
\text { redox CGI-REE } \\
\text { to oxidised } \\
\text { CGI-REE }\end{array}$ & $\begin{array}{l}\text { Olympic Dam } \\
\text { Prominent Hill } \\
\text { Carrapateena } \\
\text { Hillside } \\
\text { Eldorado? } \\
\text { Sue Dianne? }\end{array}$ \\
\hline $\begin{array}{l}\text { Hybrid: basinal } \\
\text { with minor MH } \\
\text { inputs }\end{array}$ & Manto $\mathrm{Cu}(-\mathrm{Ag})$ & Pre-orogenic? & & $\begin{array}{l}\text { Mantos Blancos } \\
\text { El Soldado }\end{array}$ \\
\hline \multirow{2}{*}{ Basinal } & Mt Isa Cu type & $\begin{array}{l}\text { Syn- } \\
\text { orogenic/syn- } \\
\text { tectonic }\end{array}$ & & Mt Isa $\mathrm{Cu}$ \\
\hline & $\begin{array}{l}\text { Sediment-hosted } \\
\text { stratiform } \mathrm{Cu} \& \\
\text { redbed } \mathrm{Cu}\end{array}$ & Diagenetic & & $\begin{array}{l}\text { Zambian \& } \\
\text { DRCongo Cu belt } \\
\text { Kupferschiefer }\end{array}$ \\
\hline
\end{tabular}

* Obsorne, Eloise, Guelb Moghrein, NICO, West Peko, Warrego, Dahongshan, Lala, Sin Quyen, Sequeirinho, Salobo, Igarapé Bahia, SWAN/Mt Elliott, Ernest Henry, E1, Monakoff, White Devil, Juno, Gecko, Starra 


\section{Summary and conclusions}

Ten of the world's most important metallogenic provinces hosting IOCG and other ore deposits have been reviewed in the present contribution, including the geochronology, geological and tectonothermal evolution, alteration-mineralisation parageneses and zoning, and ore geochemistry. In addition, the results of a review of stable and radiogenic isotope and fluid inclusion data, and interpretations of fluid and metal sources and ore-forming processes, are presented in the companion paper (Skirrow, in prep.).

A key conclusion of the present review and synthesis is that IOCG deposits form the major part of a broader family of $\mathrm{Cu}-\mathrm{Au}-\mathrm{Fe}( \pm \mathrm{Co}, \mathrm{REE})$ deposits that also includes $\mathrm{Cu}-\mathrm{Au}$ deposits lacking iron oxides. Secondly, the $\mathrm{Cu}-\mathrm{Au}-\mathrm{Fe}( \pm \mathrm{Co}, \mathrm{REE})$ family of deposits occur in three distinct tectonic settings. Two of the settings are related to orogenic processes, and host syn-orogenic and postorogenic $\mathrm{Cu}-\mathrm{Au}-\mathrm{Fe}( \pm \mathrm{Co}, \mathrm{REE})$ deposits. In the third, arc-hosted Andean-type setting, the $\mathrm{Cu}-\mathrm{Au}-$ Fe deposits formed during extension/transtension of continental margin magmatic arcs.

Third, metallogenic provinces with $\mathrm{Cu}-\mathrm{Au}-\mathrm{Fe}( \pm \mathrm{Co}, \mathrm{REE})$ deposits in all three settings are characterised by the coincidence in space and time between sedimentary \pm volcanic basins and intrusive \pm volcanic magmatism, although the compositions of the igneous rocks and relationships to deposits differs between the orogenic-related and arc-hosted settings. As argued in the companion paper, the variable inputs of basin-derived and magma-derived fluids and components is considered to be the main link between deposits in the $\mathrm{Cu}-\mathrm{Au}-\mathrm{Fe}( \pm \mathrm{Co}$, REE) family but also the principal cause of the observed variations in mineralogy and geochemistry.

Fourth, in all three settings the $\mathrm{Cu}-\mathrm{Au}-\mathrm{Fe}( \pm \mathrm{Co}, \mathrm{REE})$ deposits share several features of their alteration-mineralisation, including:

- A metal association of $\mathrm{Cu}$ and Au with elevated Fe, whether as low-Ti Fe oxides or Fe sulfides and/or Fe-rich silicates.

- Hydrothermal alteration that includes paragenetically early $\mathrm{Na}- \pm$ Ca-rich minerals (generally in regional-scale alteration zones but also proximal at some deposits) followed by combinations of $\mathrm{Fe}-$, $\mathrm{Ca}-$ and K-rich minerals that accompany or precede $\mathrm{Cu}-\mathrm{Au}$ mineralisation together with volatile-bearing minerals such as carbonate $\left(\mathrm{CO}_{2}\right)$, apatite $(\mathrm{P})$, fluorite $(\mathrm{F})$, barite $\left(\mathrm{SO}_{4}\right)$ and tourmaline (B); however, deposits in the arc-hosted settings have less abundant volatile-rich minerals.

- A paucity of Mg-rich hydrothermal minerals and hydrothermal quartz in the IOCG members of the $\mathrm{Cu}-\mathrm{Au}-\mathrm{Fe}( \pm \mathrm{Co}, \mathrm{REE})$ deposit family, but abundant quartz in many of the Fe-oxide-poor members of the family.

- Deposits in many of the $\mathrm{Cu}-\mathrm{Au}-\mathrm{Fe}( \pm \mathrm{Co}, \mathrm{REE})$ provinces exhibit a wide range of oxidation states of their hydrothermal mineralogy from reduced (e.g. pyrrhotite \pm Fe-silicatebearing) through intermediate-redox (e.g. magnetite-pyrite-bearing) to oxidised (e.g. hematite \pm pyrite \pm sulfate minerals). The $\mathrm{Cu}$ sulfide mineralogy varies systematically from chalcopyrite \pm rare bornite in the reduced deposits to chalcocite and bornite in the most oxidised deposits or zones within deposits.

- Based on whole-rock geochemical data for global ore samples (OSNACA data set, Brauhart ref) the family of $\mathrm{Cu}-\mathrm{Au}-\mathrm{Fe}( \pm \mathrm{Co}, \mathrm{REE})$ deposits are enriched in distinctive suites of minor 
elements (Co, Ni, Bi, Se, Te, REE, U, F, Ba) compared to well known magmatichydrothermal deposits such as porphyry $\mathrm{Cu}(-\mathrm{Au})$, skarn $\mathrm{Fe}$ and $\mathrm{Cu}$ and granite-related greisen deposits; however, $\mathrm{Cu}-\mathrm{Au}-\mathrm{Fe}( \pm \mathrm{Co}, \mathrm{REE})$ deposits in arc-hosted settings have lower levels of $\mathrm{Co}, \mathrm{Ni}, \mathrm{Bi}, \mathrm{Se}, \mathrm{Te}, \mathrm{REE}, \mathrm{U}, \mathrm{F}$, and $\mathrm{Ba}$ than the orogenic-related deposits.

- Conversely, the $\mathrm{Cu}-\mathrm{Au}-\mathrm{Fe}( \pm \mathrm{Co}$, REE) deposits share some features of their ore geochemistry with sediment-hosted $\mathrm{Cu}$ and volcanic-hosted massive $\mathrm{Cu}-\mathrm{Zn}-\mathrm{Pb}$ sulfide deposits (e.g. high $\mathrm{Co}, \mathrm{Ni}, \mathrm{Bi}, \mathrm{Se}, \mathrm{Te}$ ).

- Within the $\mathrm{Cu}-\mathrm{Au}-\mathrm{Fe}( \pm \mathrm{Co}, \mathrm{REE})$ deposit family there is a broad correlation between the relative abundances of $\mathrm{Co}-\mathrm{Ni}-\mathrm{Bi}-\mathrm{Se}-\mathrm{Te}$ and $\mathrm{La}-\mathrm{U}$ and the tectonic settings and alterationmineralisation mineralogy; the ratio $(\mathrm{Co}+\mathrm{Ni}+10 * \mathrm{Bi}+10 * \mathrm{Se}+50 * \mathrm{Te}) /(\mathrm{U}+\mathrm{La})$ with element values in ppm is termed the CGI discriminator.

Finally, $\mathrm{Cu}-\mathrm{Au}-\mathrm{Fe}( \pm \mathrm{Co}, \mathrm{REE})$ deposits in each of three geotectonic settings have distinctive structural, mineralogical and geochemical characteristics, as follows.

The $\mathrm{Cu}-\mathrm{Au}-\mathrm{Fe}( \pm \mathrm{Co}, \mathrm{REE})$ deposits in syn-orogenic settings include the largest group of IOCG deposits, with representatives in the Carajás, Guelb Moghrein, Tennant Creek, Kiruna, Great Bear magmatic zone, Cloncurry, Gawler-Curnamona, Kangdian and Khetri provinces. The deposits formed during brittle-ductile deformation in mesothermal (mid- to upper-crustal) environments, and have alteration-mineralisation mineral assemblages indicating generally reduced to intermediate-redox hydrothermal conditions during $\mathrm{Cu}-\mathrm{Au}$ ore formation. Where oxidised assemblages are present they are invariably later than the reduced-intermediate-redox assemblages. Sodic \pm Ca regional alteration, present in all provinces except possibly Tennant Creek, is typically overprinted by proximal alteration assemblages representing Ca-Fe metasomatism and then by $\mathrm{Fe}-\mathrm{K}$ alteration-metasomatism that accompanies the main $\mathrm{Cu}-\mathrm{Au}$ mineralisation along with volatile-rich minerals. The reduced end-members of the syn-orogenic deposit redox spectrum are characterised by variable enrichments in chalcophile-siderophile elements $(\mathrm{Cu}, \mathrm{Au}, \mathrm{Co}, \mathrm{Ni})$ and the suites $\mathrm{Bi}-\mathrm{Sb}$-As and S-Se-Te, but almost invariably lack enrichments in REE, U, F or Ba. The term CGI-Co is used to characterise this compositional endmember. Magnetite is the dominant Fe-oxide where present, but many of the most reduced $\mathrm{Cu}-$ $\mathrm{Au}-\mathrm{Fe}( \pm \mathrm{Co}, \mathrm{REE})$ deposits lack significant Fe-oxide and are dominated by Fe-sulfides. Synorogenic deposits with intermediate-redox assemblages (magnetite, pyrite) generally have lower $(\mathrm{Co}+\mathrm{Ni}+10 * \mathrm{Bi}+10 * \mathrm{Se}+50 * \mathrm{Te}) /(\mathrm{U}+\mathrm{La})$ values than the reduced deposits, due to higher REE $\pm \mathrm{U}$ values. These are termed CGI-Co-REE deposits. The (uncommon) oxidised hematite-bearing endmembers of the redox spectrum in syn-orogenic settings may have similar $(\mathrm{Co}+\mathrm{Ni}+10 * \mathrm{Bi}+10 * \mathrm{Se}+50 * \mathrm{Te}) /(\mathrm{U}+\mathrm{La})$ values to the intermediate-redox deposits but are not well represented in the available geochemical data set.

In a few cases the syn-orogenic tectonic setting evolved to a post-orogenic setting as the tectonic regime shifted from compressional to extensional or transtensional. The key example is the Gawler Craton and subjacent Curnamona Province, the former hosting the world's largest IOCG deposit at Olympic Dam. The Great Bear magmatic zone and Tennant Creek provinces may record similar switches in tectonic regime. Although the early syn-orogenic phase of hydrothermal activity is represented in the eastern Gawler Craton by early Na-Ca and Fe-K alteration and small $\mathrm{Cu}-\mathrm{Au}$ and $\mathrm{Au}-\mathrm{Mo}$ deposits, these hydrothermal expressions are overprinted by oxidised to highly oxidised hydrothermal assemblages controlled by brittle deformation features including breccia zones. Shallow-crustal to near-surface (sub-volcanic to volcanic) environments of ore formation are indicated, within a broadly extensional and syn-volcanic setting. Whereas highly oxidised 
(hematite, barite, chalcocite, bornite) and low-pH (sericite \pm pyrophyllite) conditions are evident in all of the major deposits (Olympic Dam, Prominent Hill, Carrapateena), some deposits preserve evidence of earlier and generally deeper intermediate-redox (magnetite, pyrite, siderite, chalcopyrite) chemical environments. Importantly, $\mathrm{Cu}-\mathrm{Au}-\mathrm{Fe}( \pm \mathrm{Co}, \mathrm{REE})$ ores in the Gawler postorogenic setting have the lowest values of the CGI discriminator $(\mathrm{Co}+\mathrm{Ni}+10 * \mathrm{Bi}+10 * \mathrm{Se}+50 * \mathrm{Te}) /(\mathrm{U}+\mathrm{La})$, due to low $\mathrm{Co}+\mathrm{Ni}$ and very elevated LREE (including $\mathrm{La})$ and $U$. They also contain abundant volatile-rich phases such as fluorite $(\mathrm{F})$, carbonate $\left(\mathrm{CO}_{2}\right)$, barite $\left(\mathrm{SO}_{4}\right)$, and apatite $(\mathrm{P})$ accompanying the $\mathrm{Cu}-\mathrm{Au}-\mathrm{U}-\mathrm{REE}$ mineralisation.

Arc-hosted $\mathrm{Cu}-\mathrm{Au}-\mathrm{Fe}( \pm \mathrm{Co}, \mathrm{REE})$ deposits are mainly represented by Cretaceous Fe-oxide-rich $\mathrm{Cu}$ $(-\mathrm{Au})$ deposits in the Chilean and Peruvian Andes, although hybrid settings involving Paleoproterozoic continental margin magmatic arc settings may be present in the Kiruna province and Great Bear magmatic zone. The Andean $\mathrm{Cu}-\mathrm{Au}-\mathrm{Fe}( \pm \mathrm{Co}, \mathrm{REE})$ deposits share some features of $\mathrm{Cu}-\mathrm{Au}-\mathrm{Fe}( \pm \mathrm{Co}, \mathrm{REE})$ deposits in the orogenic-related settings, including the presence of early district- to regional-scale Na-rich alteration, abundances of Fe-oxides, paucity of hydrothermal quartz, and presence of $\mathrm{Ca}-\mathrm{Fe}-\mathrm{K}$ alteration with $\mathrm{Cu}-\mathrm{Au}$ mineralisation. However, the Andean $\mathrm{Cu}-\mathrm{Au}-\mathrm{Fe}( \pm \mathrm{Co}, \mathrm{REE}$ ) tend to lack abundant volatile-rich minerals coeval with the $\mathrm{Cu}$ $\mathrm{Au}$ mineralisation, have $\mathrm{Co}+\mathrm{Ni}+\mathrm{Bi}+\mathrm{Se}+\mathrm{Te}+\mathrm{REE}+\mathrm{U}$ values that are overlapping with, or slightly elevated relative to, most porphyry and skarn deposits. They also show a sequence of hydrothermal assemblages different to those of the orogenic-related $\mathrm{Cu}-\mathrm{Au}-\mathrm{Fe}( \pm \mathrm{Co}, \mathrm{REE}$ ) deposits (i.e. the order of $\mathrm{Ca}-\mathrm{Fe}$ and $\mathrm{Fe}-\mathrm{K}$ alteration may be reversed). Moreover, their close spatial and temporal association with intermediate-composition intrusions and pre- to earlyorogenic timing contrasts with such relationships and igneous composition in the orogenicrelated deposits. The arc settings also include IOA, (small) porphyry $\mathrm{Cu}$ (-Au and skarn deposits, which are either not represented in the orogenic-related settings or, if present, appear to have formed prior to the major syn- and post-orogenic $\mathrm{Cu}-\mathrm{Au}-\mathrm{Fe}( \pm \mathrm{Co}, \mathrm{REE})$ deposits. It is concluded that the arc-hosted $\mathrm{Cu}-\mathrm{Au}-\mathrm{Fe}( \pm \mathrm{Co}, \mathrm{REE})$ deposits represent a sub-group of the $\mathrm{Cu}-\mathrm{Au}-\mathrm{Fe}( \pm \mathrm{Co}$, $\mathrm{REE})$ family with different origins to the orogenic-related $\mathrm{Cu}-\mathrm{Au}-\mathrm{Fe}( \pm \mathrm{Co}$, REE) deposits, and they appear to have a greater affinity with calc-alkaline arc-related magmatic-hydrothermal ore deposits. They may represent a variant or hybrid of magmatic-hydrothermal skarn Fe-Cu (-Au) deposits, with an influence (input?) from basinal fluids (Chen et al., 2013), as discussed in the companion paper (Skirrow, in prep.). Such a basinal fluid input may account for the Na- and Carich alteration as well as some features differentiating the arc-hosted from orogenic-related $\mathrm{Cu}$ $\mathrm{Au}-\mathrm{Fe}( \pm \mathrm{Co}, \mathrm{REE})$ deposits and from typical porphyry $\mathrm{Cu}(-\mathrm{Au})$ and skarn $\mathrm{Fe}-\mathrm{Cu}(-\mathrm{Au})$ deposits.

\section{Acknowledgements}

This work draws upon discussions with, and support from, many colleagues over the years. In particular the following people are thanked: Evgeniy Bastrakov, David Huston, Karol Czarnota, David Champion, Michael Doublier, Richard Blewett, Anthony Schofield, Simon van der Wielen (all Geoscience Australia) and also John Walshe, Sue Daly, Anthony Reid, Colin Conor, Martin Fairclough, Karin Barovich and Ken Cross. Additionally, David Huston and Evgeniy Bastrakov are thanked for helpful reviews of an early version of the manuscript. Carl Brauhart and Stefan Hagemann are acknowledged for the use of the OSNACA ore geochemical data set. Published with the permission of the CEO, Geoscience Australia. 


\section{References}

Acosta-Góngora, P., Gleeson, S. A., Samson, I. M., Corriveau, L., Ootes, L., Taylor, B. E., Creaser, R. A., \& Muehlenbachs, K. (2015). Genesis of the Paleoproterozoic NICO iron oxide-cobalt-gold-bismuth deposit, Northwest Territories, Canada: Evidence from isotope geochemistry and fluid inclusions. Precambrian Research, 268, 168-193. https://doi.org/10.1016/j.precamres.2015.06.007

Adshead, N. D., Voulgaris, P., \& Muscio, V. N. (1998). Osborne copper-gold deposit. In D. A. Berkman \& D. H. Mackenzie (Eds.), Geology of Australian and Papuan New Guinean mineral deposits (pp. 793-800). Australasian Institute of Mining and Metallurgy, Monograph 14.

Apukhtina, O. B., Kamenetsky, V. S., Ehrig, K., Kamenetsky, M. B., Maas, R., Thompson, J., McPhie, J., Ciobanu, C. L., \& Cook, N. J. (2017). Early, deep magnetite-fluorapatite mineralization at the Olympic Dam Cu-U-Au-Ag deposit, South Australia. Economic Geology, 112(6), 1531-1542. https://doi.org/10.5382/econgeo.2017.4520

Baker, T., \& Laing, W. P. (1998). Eloise Cu-Au deposit, East Mt Isa Block: Structural environment and structural controls on ore. Australian Journal of Earth Sciences, 45(3), 429-444. https://doi.org/10.1080/08120099808728402

Baker, T., Perkins, C., Blake, K. L., \& Williams, P. J. (2001). Radiogenic and stable isotope constraints on the genesis of the Eloise $\mathrm{Cu}$-Au deposits, Cloncurry district, Northwest Queensland. Economic Geology, 96(4), 723-742. https://doi.org/10.2113/gsecongeo.96.4.723

Barton, M. D. (2013). Iron Oxide(-Cu-Au-REE-P-Ag-U-Co) Systems. In Treatise on Geochemistry: Second Edition (Vol. 13, pp. 515-541). Elsevier Inc. https://doi.org/10.1016/B978-0-08-095975-7.01123-2

Bascuñán, S., Arriagada, C., le Roux, J., \& Deckart, K. (2016). Unraveling the Peruvian Phase of the Central Andes: Stratigraphy, sedimentology and geochronology of the Salar de Atacama Basin $\left(22^{\circ} 30-23^{\circ} \mathrm{S}\right)$, northern Chile. Basin Research, 28(3), 365-392. https://doi.org/10.1111/bre.12114

Bastrakov, E. N., Skirrow, R. G., \& Davidson, G. J. (2007). Fluid evolution and origins of iron oxide $\mathrm{Cu}-\mathrm{Au}$ prospects in the Olympic Dam district, Gawler Craton, South Australia. Economic Geology, 102(8). https://doi.org/10.2113/gsecongeo.102.8.1415

Belperio, A., Flint, R., \& Freeman, H. (2007). Prominent Hill: A hematite-dominated, iron oxide coppergold system. Economic Geology, 102(8), 1499-1510. https://doi.org/10.2113/gsecongeo.102.8.1499

Benavides, J., Kyser, T. K., Clark, A. H., Oates, C. J., Zamora, R., Tarnovschi, R., \& Castillo, B. (2007). The Mantoverde iron oxide-copper-gold district, III Región, Chile: The role of regionally derived, nonmagmatic fluids in chalcopyrite mineralization. Economic Geology, 102(3), 415-440. https://doi.org/10.2113/gsecongeo.102.3.415

Bonyadi, Z., \& Sadeghi, R. (2020). Hydrothermal alteration associated with magnetite mineralization in the Bafq iron deposits, Iran. Journal of Asian Earth Sciences, 189(February 2019), 104152. https://doi.org/10.1016/j.jseaes.2019.104152

Boric, R., Holmgren, C., Wilson, N. S. F., \& Zentilli, M. (2002). The geology of the El Soldado manto type Cu (Ag) deposit, central Chile. In T. M. Porter (Ed.), Hydrothermal iron oxide copper-gold and related deposits: A global perspective, Volume 2 (pp. 163-184). PGC Publishing.

Boyce, D., Charrier, R., \& Farías, M. (2020). The First Andean Compressive Tectonic Phase: Sedimentologic and Structural Analysis of Mid-Cretaceous Deposits in the Coastal Cordillera, Central Chile (32 ${ }^{\circ} 50^{\prime}$ S). Tectonics, 39(2), 1-24. https://doi.org/10.1029/2019TC005825

Brauhart, C., \& Hagemann, S. G. (2020). OSNACA (Ore Samples Normalised to Average Crustal Abundances) data base. University of Western Australia, Centre for Exploration Targeting. http://www.cet.edu.au/projects/osnaca-ore-samples-normalised-to-average-crustal-abundance

Brown, M., \& Porter, T. M. (2010). The Mount Elliott IOCG system, Eastern Fold Belt, Mount Isa Inlier, northwest Queensland. In T. M. Porter (Ed.), Hydrothermal iron oxide copper-gold and related deposits: A global perspective, Volume 3 (pp. 219-231). PGC Publishing.

Case, G. N. (2016). Genesis of the E1 Group of iron oxide-copper-gold deposits, Cloncurry district, northwest Queensland.

Cave, B. W., Lilly, R., Glorie, S., \& Gillespie, J. (2018). Geology, apatite geochronology, and geochemistry of the Ernest Henry inter-lens: Implications for a re-examined deposit model. Minerals, 8(9). https://doi.org/10.3390/min8090405

Chen, H., Clark, A. H., Kyser, T. K., Ullrich, T. D., Baxter, R., Chen, Y., \& Moody, T. C. (2010). Evolution of the giant Marcona-Mina Justa iron oxide-copper-gold district, South-Central Peru. Economic Geology, 105(1), 155-185. https://doi.org/10.2113/gsecongeo.105.1.155

Chen, H., Cooke, D. R., \& Baker, M. J. (2013). Mesozoic iron oxide copper-gold mineralization in the Central Andes and the Gondwana supercontinent breakup. Economic Geology, 108(1), 37-44.

https://doi.org/10.2113/econgeo.108.1.37 
Chen, W. T., \& Zhou, M. F. (2012). Paragenesis, stable isotopes, and molybdenite Re-Os isotope age of the Lala Iron-Copper deposit, Southwest China. Economic Geology, 107(3), 459-480. https://doi.org/10.2113/econgeo.107.3.459

Cherry, A. R., Ehrig, K., Kamenetsky, V. S., McPhie, J., Crowley, J. L., \& Kamenetsky, M. B. (2018). Precise geochronological constraints on the origin, setting and incorporation of ca. 1.59 Ga surficial facies into the Olympic Dam Breccia Complex, South Australia. Precambrian Research, 315(July), 162-178. https://doi.org/10.1016/j.precamres.2018.07.012

Conor, C. H. H. (1995). Moonta-Wallaroo region - An interpretation of the geology of the Maitland and Wallaroo 1:100 000 sheet areas.

Conor, C., Raymond, O., Baker, T., Teale, G., Say, P., \& Lowe, G. (2010). Alteration and mineralisation in the Moonta-Wallaroo copper-gold mining field region, Olympic Domain, South Australia. In T. M. Porter (Ed.), Hydrothermal iron oxide copper-gold and related deposits: A global perspective, Volume 3 (pp. 147-170). PGC Publishing.

Corriveau, L. (2007). Iron oxide copper-gold deposits: A Canadian perspecitive. In W. D. Goodfellow (Ed.), Mineral deposits in Canada: A synthesis of major deposit types, district metallogeny, the evolution of geological provinces and exploration methods (pp. 307-328). Geological Association of Canada, Mineral Deposits Division, Special Publication Volume 5.

Corriveau, L., Montreuil, J. F., \& Potter, E. G. (2016). Alteration facies linkages among iron oxide coppergold, iron oxide-apatite, and affiliated deposits in the Great Bear magmatic zone, Northwest Territories, Canada. Economic Geology, 111(8), 2045-2072. https://doi.org/10.2113/econgeo.111.8.2045

Corriveau, L., Williams, P. . J., \& Mumin, H. (2010). Alteration vectors to IOCG mineralization from uncharted terranes to deposits. In Exploring for iron oxide copper-gold deposits: Canada and global analogues (pp. 89-110). Geological Association of Canada, Short Course Notes, Volume 20.

Craveiro, G. S., Villas, R. N. N., \& Xavier, R. P. (2020). A fluid inclusion and stable isotope (0, H, S and C) study of the Archean IOCG Cristalino deposit, Carajás Mineral Province, Brazil: Implications to ore genesis. Ore Geology Reviews, 127(August), 103822. https://doi.org/10.1016/j.oregeorev.2020.103822

Cross, K. C. (1993). Acropolis and Wirrda Well prospects. In J. F. Drexel, W. v. Preiss, \& A. J. Parker (Eds.), The Geology of South Australia. Volume 1. The Precambrian (p. 138). Geological Survey of South Australia, Bulletin 54.

Day, W. C., Slack, J. F., Ayuso, R. A., \& Seeger, C. M. (2016). Regional geologic and petrologic framework for iron oxide \pm apatite \pm rare earth element and iron oxide copper-gold deposits of the Mesoproterozoic St. Francois Mountains Terrane, southeast Missouri, USA. Economic Geology, 111(8), 1825-1858. https://doi.org/10.2113/econgeo.111.8.1825

de Freitas Toledo, P. I., Moreto, C. P. N., Xavier, R. P., Gao, J., de Matos, J. H. da S. N., \& de Melo, G. H. C. (2019). Multistage evolution of the Neoarchean (ca. $2.7 \mathrm{Ga}$ ) Igarapé Cinzento (GT-46) iron oxide copper-gold deposit, Cinzento Shear Zone, Carajás Province, Brazil. Economic Geology, 114(1), 1-34. https://doi.org/10.5382/econgeo.2019.4617

de Haller, A., Corfu, F., Fontboté, L., Schaltegger, U., Barra, F., Chiaradia, M., Frank, M., \& Alvarado, J. Z. (2006). Geology, geochronology, and $\mathrm{Hf}$ and $\mathrm{Pb}$ isotope data of the Raúl-Condestable iron oxidecopper-gold deposit, central coast of Peru. Economic Geology, 101(2), 281-310. https://doi.org/10.2113/gsecongeo.101.2.281

de Melo, G. H. C., Monteiro, L. V. S., Xavier, R. P., Moreto, C. P. N., \& Santiago, E. (2019). Tracing fluid sources for the Salobo and Igarapé Bahia deposits: Implications for the genesis of the iron oxide copper-gold deposits in the Carajás Province, Brazil. Economic Geology, 114(4), 697-718. https://doi.org/10.5382/econgeo.4659

de Melo, G. H. C., Monteiro, L. V. S., Xavier, R. P., Moreto, C. P. N., Santiago, E. S. B., Dufrane, S. A., Aires, B., \& Santos, A. F. F. (2017). Temporal evolution of the giant Salobo IOCG deposit, Carajás Province (Brazil): constraints from paragenesis of hydrothermal alteration and $\mathrm{U}-\mathrm{Pb}$ geochronology. Mineralium Deposita, 52(5), 709-732. https://doi.org/10.1007/s00126-016-0693-5

del Real, I., Thompson, J. F. H., \& Carriedo, J. (2018). Lithological and structural controls on the genesis of the Candelaria-Punta del Cobre Iron Oxide Copper Gold district, Northern Chile. Ore Geology Reviews, 102(August), 106-153. https://doi.org/10.1016/j.oregeorev.2018.08.034

Donnellan, N., Hussey, K. J., \& Morrison, R. S. (1995). Flynn 5759, Tennant Creek 5758: Explanatory Notes, 1:100 000 Geological Map Series.

Duncan, R. J., Stein, H. J., Evans, K. A., Hitzman, M. W., Nelson, E. P., \& Kirwin, D. J. (2011). A new geochronological framework for mineralization and alteration in the Selwyn-Mount Dore corridor, 
Eastern Fold Belt, Mount Isa Inlier, Australia: Genetic implications for iron oxide copper-gold deposits. Economic Geology, 106(2), 169-192. https://doi.org/10.2113/econgeo.106.2.169

Ehrig, K. J., McPhie, J., \& Kamenetsky, V. S. (2012). Geology and mineralogical zonation of the Olympic Dam iron oxide Cu-U-Au-Ag deposit, South Australia. In J. W. Hedenquist, M. Harris, \& F. Camus (Eds.), Geology and Genesis of Major Copper Deposits and Districts of the World: A Tribute to Richard H. Sillitoe. Special Publication 16 (pp. 237-267). Society of Economic Geologists. https://doi.org/10.5382/sp.17

Fairclough, M. (2005). Geological and metallogenic setting of the Carrapateena FeO-Cu-Au prospect - a PACE success story. MESA Journal, 38(July), 4-7.

Fennell, L. M., Iannelli, S. B., Encinas, A., Naipauer, M., Valencia, V., \& Folguera, A. S. (2019). Alternating contraction and extension in the southern central Andes $\left(35^{\circ}-37^{\circ} \mathrm{s}\right)$. American Journal of Science, 319(5), 381-429. https://doi.org/10.2475/05.2019.02

Fisher, L. A., \& Kendrick, M. A. (2008). Metamorphic fluid origins in the Osborne Fe oxide - Cu - Au deposit, Australia: Evidence from noble gases and halogens. Mineralium Deposita, 43(5), 483-497. https://doi.org/10.1007/s00126-008-0178-2

Gas'kov, I. v., Anh, T. T., Hoa, T. T., Dung, P. T., Nevol'ko, P. A., \& Can, P. N. (2012). The Sin Quyen Cu-Fe-AuREE deposit (northern Vietnam): Composition and formation conditions. Russian Geology and Geophysics, 53(5), 442-456. https://doi.org/10.1016/j.rgg.2012.03.005

Ghandi, S. S. (2015). World Fe oxide +/- Cu-Au-U (IOCG) deposit database. https://doi.org/https://doi.org/10.4095/296424

Goad, R. E., Mumin, H., Duke, N. A., Neale, K. L., \& Mulligan, D. L. (2000). Geology of the Proterozoic iron oxide-hosted, NICO cobalt-gold-bismuth, and Sue-Dianne copper-silver deposits, southern Great Bear magmatic zone, Northwest Territories, Canada. In T. M. Porter (Ed.), Hydrothermal iron oxide copper-gold and related deposits: A global perspective, Volume 1 (pp. 249-267). Australian Mineral Foundation.

Grainger, C. J., Groves, D. I., Tallarico, F. H. B., \& Fletcher, I. R. (2008). Metallogenesis of the Carajás Mineral Province, Southern Amazon Craton, Brazil: Varying styles of Archean through Paleoproterozoic to Neoproterozoic base- and precious-metal mineralisation. Ore Geology Reviews, 33(3-4), 451-489. https://doi.org/10.1016/j.oregeorev.2006.10.010

Groves, D. I., Bierlein, F. P., Meinert, L. D., \& Hitzman, M. W. (2010). Iron Oxide Copper-Gold (IOCG) Deposits through Earth History: Implications for Origin, Lithospheric Setting, and Distinction from Other Epigenetic Iron Oxide Deposits. Economic Geology, 105, 641-654.

Haynes, D. W. (2000). Iron oxide copper (-gold) deposits: their position in the deposit spectrum and modes of origin. In Hydrothermal iron oxide copper-gold and related deposits: A global perspective, Volume 1 (pp. 71-90). Australian Mineral Foundation.

Haynes, D. W., Cross, K. C., Bills, R. T., \& Reed, M. H. (1995). Olympic Dam ore genesis: a fluid-mixing model. Economic Geology, 90(2), 281-307. https://doi.org/10.2113/gsecongeo.90.2.281

Hildebrand, R. S., Hoffman, P. F., \& Bowring, S. A. (1987). Tectono-magmatic evolution of the 1.9-Ga Great Bear magmatic zone, Wopmay orogen, northwestern Canada. Journal of Volcanology and Geothermal Research, 32(1-3), 99-118. https://doi.org/10.1016/0377-0273(87)90039-4

Hitzman, M. W. (2000). Iron oxide-Cu-Au deposits: what, where, when and why? In T. M. Porter (Ed.), Hydrothermal iron oxide copper-gold and related deposits: A global perspective, Volume 1 (pp. 9-25). Australian Mineral Foundation.

Hitzman, Murray W, Oreskes, N., \& Einaudi, M. T. (1992). Geological characteristics and tectonic setting of Proterozoic iron oxide (Cu-U-Au-REE) deposits. In Precambrian Research (Vol. 58).

Hoggard, M. J., Czarnota, K., Richards, F. D., Huston, D. L., Jaques, A. L., \& Ghelichkhan, S. (2020). Global distribution of sediment-hosted metals controlled by craton edge stability. Nature Geoscience, 13(7), 504-510. https://doi.org/10.1038/s41561-020-0593-2

Hopper, D., \& Correa, A. (2000). The Panulcillo and Teresa de Colmo copper deposits: two contrasting examples of Fe-ox Cu-Au mineralization from the Coastal Cordillera of Chile. In T. M. Porter (Ed.), Hydrothermal iron oxide copper-gold and related deposits: A global perspective, Volume 1 (pp. 177189). Australian Mineral Foundation.

Huang, Q., Kamenetsky, V. S., Ehrig, K., McPhie, J., Kamenetsky, M., Cross, K., Meffre, S., Agangi, A., Chambefort, I., Direen, N. G., Maas, R., \& Apukhtina, O. (2016). Olivine-phyric basalt in the Mesoproterozoic Gawler silicic large igneous province, South Australia: Examples at the Olympic Dam iron oxide $\mathrm{Cu}-\mathrm{U}-\mathrm{Au}-\mathrm{Ag}$ deposit and other localities. Precambrian Research, 281, 185-199. https://doi.org/10.1016/j.precamres.2016.05.019 
Huston, D. L., Bolger, C., \& Cozens, G. (1993). A comparison of mineral deposits at the Gecko and White Devil deposits: implications for ore genesis in the Tennant Creek district, Northern Territory, Australia. Economic Geology, 88(5), 1198-1225. https://doi.org/10.2113/gsecongeo.88.5.1198

Ismail, R., Ciobanu, C. L., Cook, N. J., Teale, G. S., Giles, D., Mumm, A. S., \& Wade, B. (2014). Rare earths and other trace elements in minerals from skarn assemblages, Hillside iron oxide-copper-gold deposit, Yorke Peninsula, South Australia. Lithos, 184-187, 456-477. https://doi.org/10.1016/j.lithos.2013.07.023

Johnson, J. P., \& Cross, K. C. (1995). U-Pb geochronological constraints on the genesis of the Olympic Dam $\mathrm{Cu}-\mathrm{U}-\mathrm{Au}-\mathrm{Ag}$ deposit, South Australia. Economic Geology, 90, 1046-1063.

Johnson, James P., \& McCulloch, M. T. (1995). Sources of mineralising fluids for the Olympic Dam deposit (South Australia): Sm-Nd isotopic constraints. Chemical Geology, 121(1-4), 177-199. https://doi.org/10.1016/0009-2541(94)00125-R

Kirschbaum, M. J., \& Hitzman, M. W. (2016). Guelb Moghrein: an unusual, carbonate-hosted iron oxide copper-gold deposit in Mauritania, northwest Africa. Economic Geology, 763-770.

Knight, J., Joy, S., Lowe, J., Cameron, J., Merrillees, J., Nag, S., Shah, N., Dua, G., \& Jhala, K. (2002). The Khetri copper belt, Rajasthan: iron oxide copper-gold terrane in the Proterozoic of NW India. In T. M. Porter (Ed.), Hydrothermal iron oxide copper-gold and related deposits: A global perspective, Volume 2 (pp. 321-341). PGC Publishing.

Kolb, J., Meyer, M., Vennemann, T., Sindern, S., Prantl, S., \& Bottcher, M. E. (2010). Characterisation of the hydrothermal fluids of the Guelb Moghrein iron oxide-Cu-Au-Co deposit, Mauritania: ore mineral chemistry, fluid inclusions and isotope geochemistry. In T. M. Porter (Ed.), Hydrothermal iron oxide copper-gold and related deposits: A global perspective, Volume 4 (pp. 553-572). PGC Publishing.

Kolb, J., \& Petrov, N. (2016). The Guelb Moghrein Cu-Au deposit: Neoarchaean hydrothermal sulfide mineralization in carbonate-facies iron formation. Ore Geology Reviews, 78, 573-577. https://doi.org/10.1016/j.oregeorev.2015.09.003

Krneta, S., Cook, N. J., Ciobanu, C. L., Ehrig, K., \& Kontonikas-Charos, A. (2017). The Wirrda Well and Acropolis prospects, Gawler Craton, South Australia: Insights into evolving fluid conditions through apatite chemistry. Journal of Geochemical Exploration, 181(May), 276-291. https://doi.org/10.1016/j.gexplo.2017.08.004

Large, R. R. (1975). Zonation of hydrothermal minerals at the Juno Mine, Tennant Creek goldfield, central Australia. Economic Geology, 70, 1387-1413. https://doi.org/10.2113/gsecongeo.71.8.1615

Li, W., Audétat, A., \& Zhang, J. (2015). The role of evaporites in the formation of magnetite-apatite deposits along the Middle and Lower Yangtze River, China: Evidence from LA-ICP-MS analysis of fluid inclusions. Ore Geology Reviews, 67, 264-278. https://doi.org/10.1016/j.oregeorev.2014.12.003

Li, X. C., \& Zhou, M. F. (2018). The nature and origin of hydrothermal REE mineralization in the Sin Quyen deposit, northwestern Vietnam. Economic Geology, 113(3), 645-673. https://doi.org/10.5382/econgeo.2018.4565

Li, X. C., Zhou, M. F., Williams-Jones, A. E., Yang, Y. H., \& Gao, J. F. (2019). Timing and genesis of Cu-(Au) mineralization in the Khetri Copper Belt, northwestern india: Constraints from in situ U-Pb ages and Sm-Nd isotopes of monazite-(Ce). Mineralium Deposita, 54(4), 553-568. https://doi.org/10.1007/s00126-018-0823-3

Li, X., Zhao, X., Zhou, M. F., Chen, W. T., \& Chu, Z. (2015). Fluid inclusion and isotopic constraints on the origin of the Paleoproterozoic Yinachang Fe-Cu-(REE) deposit, Southwest China. Economic Geology, 110(5), 1339-1369. https://doi.org/10.2113/econgeo.110.5.1339

Lin, L., Chen, R., Pang, Z., Chen, H., Xue, J., \& Jia, H. (2020). Sulfide Rb-Sr, Re-Os and in-situ S isotopic constraints on two mineralization events at the large Hongnipo Cu deposit, SW China. Minerals, 10(5), 1-24. https://doi.org/10.3390/min10050414

Lu, C., Grand, S. P., Lai, H., \& Garnero, E. J. (2019). TX2019slab: A New P and S Tomography Model Incorporating Subducting Slabs. Journal of Geophysical Research: Solid Earth, 124(11), 1154911567. https://doi.org/10.1029/2019JB017448

Maksaev, V., \& Zentilli, M. (2002). Chilean strata-bound Cu- (Ag) deposits: An overview. In T. M. Porter (Ed.), Hydrothermal iron oxide copper-gold and related deposits: A global perspective, Volume 2 (pp. 185-205). PGC Publishing.

Mark, G., Oliver, N. H. S., \& Williams, P. J. (2006). Mineralogical and chemical evolution of the Ernest Henry Fe oxide-Cu-Au ore system, Cloncurry district, northwest Queensland, Australia. Mineralium Deposita, 40(8), 769-801. https://doi.org/10.1007/s00126-005-0009-7

Marschik, R., \& Fontboté, L. (2001). The Candelaria-Punta del Cobre iron oxide Cu-Au (-Zn-Ag) deposits, Chile. Economic Geology, 96(8), 1799-1826. https://doi.org/10.2113/gsecongeo.96.8.1799 
Martinsson, O., Billström, K., Broman, C., Weihed, P., \& Wanhainen, C. (2016). Metallogeny of the Northern Norrbotten Ore Province, Northern Fennoscandian Shield with emphasis on IOCG and apatite-iron ore deposits. Ore Geology Reviews, 78, 447-492. https://doi.org/10.1016/j.oregeorev.2016.02.011

McLean, R. N. (2002). The Sin Quyen iron oxide-copper-gold-rare earth oxide mineralisation of north Vietnam. In T. M. Porter (Ed.), Hydrothermal iron oxide copper-gold and related deposits: A global perspective, Volume 2 (pp. 293-301). PGC Publishing.

McPhie, J., Ehrig, K. J., Kamenetsky, M. B., Crowley, J. L., \& Kamenetsky, V. S. (2020). Geology of the Acropolis prospect, South Australia, constrained by high-precision CA-TIMS ages. Australian Journal of Earth Sciences, 67(5), 699-716. https://doi.org/10.1080/08120099.2020.1717617

Meinert, L. D., Dipple, G. M., \& Nicolescu, S. (2005). World skarn deposits. In J. W. Hedenquist, J. F. H. Thompson, R. J. Goldfarb, \& J. P. Richards (Eds.), One Hundredth Anniversary Volume. Society of Economic Geologists. https://doi.org/https://doi.org/10.5382/AV100.11

Meyer, C. (1988). Ore deposits as guides to geologic history of the Earth. In Ann. Rev. Earth Planet. Sci (Vol. 16). www.annualreviews.org

Miyano, T., \& Klein, C. (1989). Phase equilibria in the system K2O - FeO - MgO - Al2O3 - SiO2 - H2O - CO2 and the stability limit of stilpnomelane in metamorphosed Precambrian iron-formations.

Contributions to Mineralogy and Petrology, 478-491.

Monteiro, L. V. S., Xavier, R. P., Carvalho, E. R., Hitzman, M. W., Johnson, C. A., Souza Filho, C. R., \& Torresi, I. (2008). Spatial and temporal zoning of hydrothermal alteration and mineralization in the Sossego iron oxide-copper-gold deposit, Carajás Mineral Province, Brazil: Paragenesis and stable isotope constraints. In Mineralium Deposita (Vol. 43, Issue 2). https://doi.org/10.1007/s00126-006-0121-3

Montreuil, J. F., Corriveau, L., \& Davis, W. J. (2016). Tectonomagmatic evolution of the southern Great Bear magmatic zone (Northwest Territories, Canada): Implications for the genesis of iron oxide-alkalialtered hydrothermal systems. Economic Geology, 111(8), 2111-2138. https://doi.org/10.2113/econgeo.111.8.2111

Moreto, C. P. N., Monteiro, L. V. S., Xavier, R. P., Amaral, W. S., dos Santos, T. J. S., Juliani, C., \& de Filho, C. R. S. (2011). Mesoarchean (3.0 and $2.86 \mathrm{Ga}$ ) host rocks of the iron oxide-Cu-Au Bacaba deposit, Carajás Mineral Province: U-Pb geochronology and metallogenetic implications. Mineralium Deposita, 46(7), 789-811. https://doi.org/10.1007/s00126-011-0352-9

Mukhopadhyay, S., Kumar, V., \& Sangwan, M. (2019). Sediment Hosted Stratiform Copper (SSC) Mineralization in Bhudoli-Basari Area, North Delhi Fold Belt, Mesoproterozoic Delhi Supergroup, Rajasthan. Journal of the Geological Society of India, 93(6), 663-674. https://doi.org/10.1007/s12594-019-1245-2

Ootes, L., Snyder, D., Davis, W. J., Acosta-Góngora, P., Corriveau, L., Mumin, A. H., Gleeson, S. A., Samson, I. M., Montreuil, J. F., Potter, E., \& Jackson, V. A. (2017). A Paleoproterozoic Andean-type iron oxide copper-gold environment, the Great Bear magmatic zone, Northwest Canada. Ore Geology Reviews, 81, 123-139. https://doi.org/10.1016/j.oregeorev.2016.09.024

Oreskes, N., \& Einaudi, M. T. (1990). Origin of rare earth element-enriched hematite breccias at the Olympic Dam Cu-U-Au-Ag deposit, Roxby Downs, South Australia. Economic Geology, 85(1), 1-28. https://doi.org/10.2113/gsecongeo.85.1.1

Oreskes, N., \& Einaudi, M. T. (1992). Origin of hydrothermal fluids at Olympic Dam: preliminary results from fluid inclusions and stable isotopes. Economic Geology, 87(1), 64-90. https://doi.org/10.2113/gsecongeo.87.1.64

Oyarzun, R., Oyarzún, J., Ménard, J. J., \& Lillo, J. (2003). The Cretaceous iron belt of northern Chile: Role of oceanic plates, a superplume event, and a major shear zone. Mineralium Deposita, 38(5), 640-646. https://doi.org/10.1007/s00126-003-0359-y

Oyunjargal, L., Hayashi, K., \& Teruyuki, M. (2020). Geological, mineralogical, and oxygen isotope studies of the Chandmani Uul iron oxide - copper - gold deposit in Dornogobi Province, southeastern Mongolia. Resource Geology, January, 233-253. https://doi.org/10.1111/rge.12232

Pestilho, A. L. S., Monteiro, L. V. S., Melo, G. H. C. de, Moreto, C. P. N., Juliani, C., Fallick, A. E., \& Xavier, R. P. (2020). Stable isotopes and fluid inclusion constraints on the fluid evolution in the Bacaba and Castanha iron oxide-copper-gold deposits, Carajás Mineral Province, Brazil. Ore Geology Reviews, 126(April 2019), 103738. https://doi.org/10.1016/j.oregeorev.2020.103738

Porter, T. M. (2010a). Current understanding of iron oxide associated-alkali altered mineralised systems: Part I - An overview. In T. M. Porter (Ed.), Hydrothermal iron oxide copper-gold and related deposits: A global perspective, Volume 3 (pp. 5-32). PGC Publishing.

Porter, T. M. (2010b). The Carrapateena iron oxide copper gold deposit, Gawler Craton, South Australia: a review. In T. M. Porter (Ed.), Hydrothermal iron oxide copper-gold and related deposits: A global perspective, Volume 3 (pp. 191-200). PGC Publishing. 
Previato, M., Monteiro, L. V. S., Bello, R. M. da S., \& Gonçales, L. C. G. (2020). Evolution of brines and C02rich fluids and hydrothermal overprinting in the genesis of the Borrachudo copper deposit, Carajás Province. Ore Geology Reviews, 121(March), 103561. https://doi.org/10.1016/j.oregeorev.2020.103561

Ramírez, L. E., Palacios, C., Townley, B., Parada, M. A., Sial, A. N., Fernandez-Turiel, J. L., Gimeno, D., GarciaValles, M., \& Lehmann, B. (2006). The Mantos Blancos copper deposit: An Upper Jurassic brecciastyle hydrothermal system in the Coastal Range of northern Chile. Mineralium Deposita, 41(3), 246258. https://doi.org/10.1007/s00126-006-0055-9

Reeve, J. S., Cross, K. C., Smith, R. N., \& Oreskes, N. (1990). Olympic Dam copper-uranium-gold-silver deposit. In F. E. Hughes (Ed.), Geology of the mineral deposits of Australia and Papua New Guinea (pp. 1009-1035). Australasian Institute of Mining and Metallurgy, Monograph 14.

Richards, J. P., Lopez, G. P., Zhu, J. J., Creaser, R. A., Locock, A. J., \& Mumin, A. H. (2017). Contrasting tectonic settings and sulfur contents of magmas associated with cretaceous porphyry $\mathrm{Cu} \pm \mathrm{Mo} \pm \mathrm{Au}$ and intrusion-related iron oxide $\mathrm{Cu}-\mathrm{Au}$ deposits in northern Chile. Economic Geology, 112(2), 295-318. https://doi.org/10.2113/econgeo.112.2.295

Rieger, A. A., Marschik, R., Díaz, M., Hölzl, S., Chiaradia, M., Akker, B., \& Spangenberg, J. E. (2010). The hypogene iron oxide copper-gold mineralization in the Mantoverde district, northern Chile. Economic Geology, 105(7), 1271-1299. https://doi.org/10.2113/econgeo.105.7.1271

Rojas, P. A., Barra, F., Reich, M., Deditius, A., Simon, A., Uribe, F., Romero, R., \& Rojo, M. (2018). A genetic link between magnetite mineralization and diorite intrusion at the El Romeral iron oxide-apatite deposit, northern Chile. Mineralium Deposita, 53(7), 947-966. https://doi.org/10.1007/s00126017-0777-x

Rotherham, J. F. (1997). A metasomatic origin for the iron-oxide Au-Cu Starra orebodies, Eastern Fold Belt, Mount Isa Inlier. Mineralium Deposita, 32(3), 205-218. https://doi.org/10.1007/s001260050086

Rotherham, J. F., Blake, K. L., Cartwright, I. ., \& Williams, P. J. (1998). Stable isotope evidence for the origin of the Mesoproterozoic Starra Au-Cu deposit, Cloncurry district, northwest Queensland. Economic Geology, 93, 1435-1449.

Salazar, E., Barra, F., Reich, M., Simon, A., Leisen, M., Palma, G., Romero, R., \& Rojo, M. (2020). Trace element geochemistry of magnetite from the Cerro Negro Norte iron oxide-apatite deposit, northern Chile. Mineralium Deposita, 55(3), 409-428. https://doi.org/10.1007/s00126-019-008793

Sangster, D. F. (2020). Evidence that Broken Hill-type Pb-Zn deposits are metamorphosed SEDEX deposits. Mineralium Deposita, 55(7), 1263-1270. https://doi.org/10.1007/s00126-020-00975-9

Schlegel, T. U., \& Heinrich, C. A. (2015). Lithology and hydrothermal alteration control the distribution of copper grade in the Prominent Hill iron oxide-copper-gold deposit (Gawler Craton, South Australia). Economic Geology, 110(8), 1953-1994. https://doi.org/10.2113/econgeo.110.8.1953

Schlegel, T. U., Wagner, T., Wälle, M., \& Heinrich, C. A. (2018). Hematite breccia-hosted iron oxide coppergold deposits require magmatic fluid components exposed to atmospheric oxidation: Evidence from Prominent Hill, Gawler Craton, South Australia. Economic Geology, 113(3), 597-644. https://doi.org/10.5382/econgeo.2018.4564

Sillitoe, R. H. (2003). Iron oxide-copper-gold deposits: An Andean view. Mineralium Deposita, 38(7), 787812. https://doi.org/10.1007/s00126-003-0379-7

Sillitoe, R. H. (2010). Porphyry copper systems. Economic Geology, 105(1), 3-41. https://doi.org/10.2113/gsecongeo.105.1.3

Sillitoe, R. H., Magaranov, G., Mladenov, V., \& Creaser, R. A. (2020). Rosen, Bulgaria: A newly recognized iron oxide-copper-gold district. Economic Geology, 115(3), 481-488. https://doi.org/10.5382/ECONGE0.4731

Skirrow, R. G. (1993). The genesis of gold-copper-bismuth deposits, Tennant Creek, Northern Territory. Unpublished PhD thesis, Australian National University.

Skirrow, R. G. (2000). Gold-copper-bismuth deposits of the Tennant Creek district, Australia: a reappraisal of diverse high-grade systems. In T. M. Porter (Ed.), Hydrothermal iron oxide copper-gold and related deposits: A global perspective, Volume 1 (pp. 149-160). Australian Mineral Foundation.

Skirrow, R. G., Ashley, P. M., McNaughton, M. J., \& Suzuki, K. (2000). Time-space framework of Cu-Au(-Mo) and regional alteration systems in the Curnamona Province. AGSO Record 2000/10, 83-86.

Skirrow, R. G., Bastrakov, E. N., Barovich, K., Fraser, G. L., Creaser, R. A., Fanning, C. M., Raymond, O. L., \& Davidson, G. J. (2007). Timing of iron oxide $\mathrm{Cu}-\mathrm{Au}-(\mathrm{U})$ hydrothermal activity and Nd isotope constraints on metal sources in the Gawler craton, South Australia. Economic Geology, 102(8). https://doi.org/10.2113/gsecongeo.102.8.1441 
Skirrow, R. G., Bastrakov, E. N., Davidson, G. J., Raymond, O. L., \& Heithersay, P. (2002). The geological framework, distribution and controls of Fe-oxide $\mathrm{Cu}$-Au mineralisation in the Gawler craton, South Australia: Part II - Alteration and mineralisation. In T. M. Porter (Ed.), Hydrothermal iron oxide copper-gold and related deposits: A global perspective, Volume 2 (pp. 33-47). PGC Publishing.

Skirrow, R. G., van der Wielen, S. E., Champion, D. C., Czarnota, K., \& Thiel, S. (2018). Lithospheric Architecture and Mantle Metasomatism Linked to Iron Oxide $\mathrm{Cu}-\mathrm{Au}$ Ore Formation: Multidisciplinary Evidence from the Olympic Dam Region, South Australia. Geochemistry, Geophysics, Geosystems, 19(8). https://doi.org/10.1029/2018GC007561

Skirrow, R. G., \& Walshe, J. L. (2002). Reduced and oxidized Au-Cu-Bi iron oxide deposits of the Tennant Creek Inlier, Australia: An integrated geologic and chemical model. Economic Geology, 97(6). https://doi.org/10.2113/gsecongeo.97.6.1167

Spry, P. G., \& Teale, G. S. (2021). A classification of Broken Hill-type deposits: A critical review. Ore Geology Reviews, 130(January), 103935. https://doi.org/10.1016/j.oregeorev.2020.103935

Teale, G. S., \& Fanning, C. M. (2000a). The Portia - North Portia Cu-Au(-Mo) prospect, South Australia: timing of mineralisation, albitisation and origin of ore fluid. In T. M. Porter (Ed.), Hydrothermal iron oxide copper-gold and related deposits: A global perspective, Volume 1 (pp. 137-147). Australian Mineral Foundation.

Teale, G. S., \& Fanning, C. M. (2000b). The timing of Cu-Au mineralisation in the Curnamona Province. AGSO Record 2000/10, 98-100.

Tiddy, C. J., \& Giles, D. (2020). Suprasubduction zone model for metal endowment at 1.60-1.57 Ga in eastern Australia. Ore Geology Reviews, 122(March), 103483. https://doi.org/10.1016/j.oregeorev.2020.103483

Tornos, F., Velasco, F., \& Hanchar, J. M. (2016). Iron-rich melts, magmatic magnetite, and superheated hydrothermal systems: The El Laco deposit, Chile. Geology, 44(6), 427-430. https://doi.org/10.1130/G37705.1

Wang, S., \& Williams, P. J. (2001). Geochemistry and origin of Proterozoic skarns at the Mount Elliott Cu$\mathrm{Au}(-\mathrm{Co}-\mathrm{Ni})$ deposit, Cloncurry district, NW Queensland, Australia. Mineralium Deposita, 36(2), 109124. https://doi.org/10.1007/s001260050292

Wedekind, M. R., Large, R. R., \& Williams, B. T. (1989). Controls on high-grade gold mineralization at Tennant Creek, Northern Territory, Australia (pp. 168-179). Economic Geology, Monograph 6.

Williams, M. R., Holwell, D. A., Lilly, R. M., Case, G. N. D., \& McDonald, I. (2015). Mineralogical and fluid characteristics of the fluorite-rich Monakoff and E1 Cu-Au deposits, Cloncurry region, Queensland, Australia: Implications for regional F-Ba-rich IOCG mineralisation. Ore Geology Reviews, 64(1), 103127. https://doi.org/10.1016/j.oregeorev.2014.05.021

Williams, P. J. (2010). Classifying IOCG deposits. In L. Corriveau \& H. Mumin (Eds.), Exploring for iron oxide copper-gold deposits: Canada and global analogues (pp. 13-21). Geological Association of Canada, Short Course Notes, Volume 20.

Williams, P. J., Barton, M. D., Johnson, D. A., Fontboté, L., de Haller, A., Mark, G., Oliver, N. H. S., \& Marschik, R. (2005). Iron oxide copper-gold deposits: Geology, space-time distributions, and possible modes of origin. Economic Geology, 100, 371-405.

Williams, P. J., \& Skirrow, R. G. (2000). Overview of iron oxide-copper-gold deposits in the Curnamona Province and Cloncurry district (Mount Isa Block), Australia. In T. M. Porter (Ed.), Hydrothermal iron oxide copper-gold and related deposits: A global perspective, Volume 1 (pp. 105-122). Australian Mineral Foundation.

Wilson, N. S. F., Zentilli, M., Reynolds, P. H., \& Boric, R. (2003). Age of mineralization by basinal fluids at the El Soldado manto-type copper deposit, Chile: 40Ar/39Ar geochronology of K-feldspar. Chemical Geology, 197(1-4), 161-176. https://doi.org/10.1016/S0009-2541(02)00350-9

Yu, J., Che, L., \& Wang, T. (2015). Alteration, oxygen isotope, and fluid inclusion study of the Meishan iron oxide-apatite deposit, SE China. Mineralium Deposita, 50(7), 847-869. https://doi.org/10.1007/s00126-015-0577-0

Zhao, X. F., \& Zhou, M. F. (2011). Fe-Cu deposits in the Kangdian region, SW China: A Proterozoic IOCG (iron-oxide-copper-gold) metallogenic province. Mineralium Deposita, 46(7), 731-747. https://doi.org/10.1007/s00126-011-0342-y

Zhao, X. F., Zhou, M. F., Su, Z. K., Li, X. C., Chen, W. T., \& Li, J. W. (2017). Geology, geochronology, and geochemistry of the Dahongshan Fe-Cu-(Au-Ag) deposit, southwest China: Implications for the formation of iron oxide copper-gold deposits in intracratonic rift settings. Economic Geology, 112(3), 603-628. https://doi.org/10.2113/econgeo.112.3.603

Zhou, M. F., Zhao, X. F., Chen, W. T., Li, X. C., Wang, W., Yan, D. P., \& Qiu, H. N. (2014). Proterozoic Fe-Cu metallogeny and supercontinental cycles of the southwestern Yangtze Block, southern China and 
northern Vietnam. Earth-Science Reviews, 139, 59-82.

https://doi.org/10.1016/j.earscirev.2014.08.013 
Appendix 1. References for Figure 4, paragenetic sequences.

Carajás province, Brazil (Cristalino, Igarapé-Bahia, Salobo, Bacaba, Sossego-Sequeirinho deposits): Monteiro et al. (2008); Moreto et al. (2011); de Melo et al. (2017); de Melo et al. (2019); Craveiro et al. (2020); Pestilho et al. (2020)

Cloncurry province, Australia (Ernest Henry, E1, StarRotherham (1997); Baker \& Laing (1998); Baker et al. (2001); Mark et al. (2006); Fisher \& Kendrick (2008); Williams et al. (2015); Case (2016); Cave et al. (2018)Rotherham (1997); Baker \& Laing (1998); Baker et al. (2001); Mark et al. (2006); Fisher \& Kendrick (2008); Williams et al. (2015); Case (2016); Cave et al. (2018)

Sin Quyen deposit, Vietnam (possible extension of Kangdian province): McLean (2002); Li \& Zhou (2018)

Kangdian province, China (Dahongshan, Yinachang, Lala deposits): Chen \& Zhou (2012); Li et al. (2015); Zhao et al. (2017)

Gawler Craton and Curnamona Province, Australia (Olympic Dam, Prominent Hill, Hillside, Wallaroo, North Portia deposits): Oreskes \& Einaudi (1990); Reeve et al. (1990); Conor (1995); Haynes et al. (1995); Teale \& Fanning (2000a); Skirrow et al. (2002); Conor et al. (2010); Ehrig et al. (2012); Ismail et al. (2014); Schlegel \& Heinrich (2015)

Tennant Creek province, Australia (Eldorado, Juno, West Peko deposits): Large (1975); Skirrow \& Walshe (2002)

Guelb Moghrein deposit, Mauritania: Kolb et al. (2010); Kirschbaum \& Hitzman (2016); Kolb \& Petrov (2016)

Great Bear magmatic zone, Canada (NICO deposit): Goad et al. (2000); Acosta-Góngora et al. (2015)

Andes province, Chile and Peru (Panulcillo, Mantoverde, Mina Justa, Candelaria, RaúlCondestable deposits): Hopper \& Correa (2000); Marschik \& Fontboté (2001); de Haller et al. (2006); Benavides et al. (2007); Chen et al. (2010); Rieger et al. (2010); del Real et al. (2018) 
Appendix 2. Fe-oxide and $\mathrm{Fe}-\mathrm{Cu}$ sulfide mineralogical characteristics of $\mathrm{Cu}-\mathrm{Au}-\mathrm{Fe}( \pm \mathrm{Co}, \mathrm{REE})$ provinces.

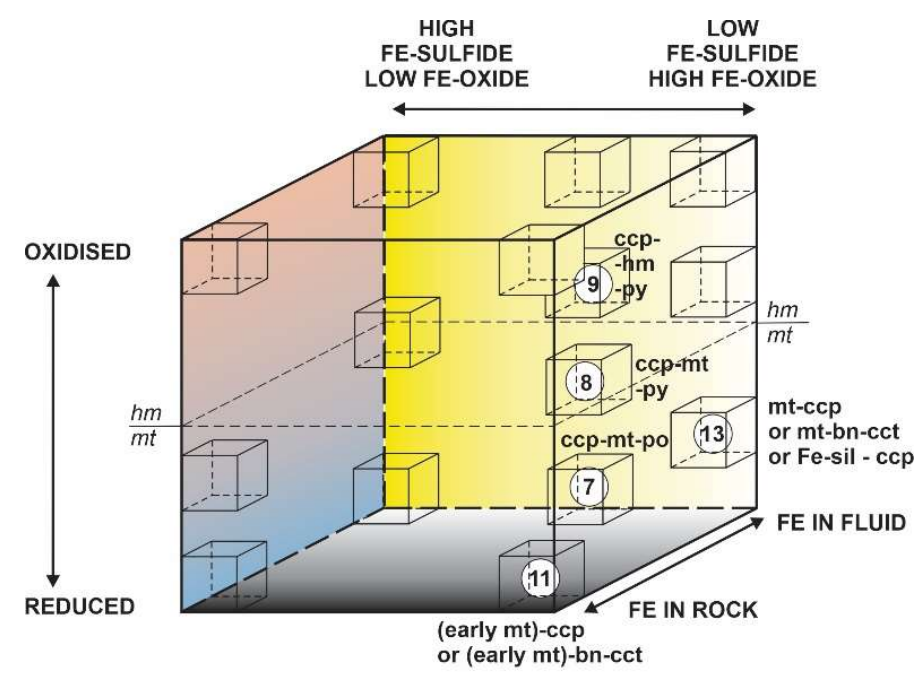

Carajas Neoarchean Cu-Au-Fe (Co, Ni, REE) deposits

(7) Sossego-Sequerinho Cu-Au, Castanha $\mathrm{Cu}-\mathrm{Au}(\mathrm{Co}, \mathrm{Ni})$

(8) Sossego-Sequerinho Cu-Au, Cristalino (Cu-Au), Borrachudo Cu-Au (Co, Ni, REE),

tanha Cu-Au (Co, Ni)

(9) Cristalino $\mathrm{Cu}-\mathrm{Au}$

(11) Salobo Cu-Au (Co, REE) (early BIF mt?)

13 Salobo Cu-Au (Co, REE) (mt-bn-ccp-cct-flu), Bacaba Cu-Au (mt-ccp), Igarape Bahia Cu-Au (mt-bn-ccp-cct), Igarape Cinzento (GT-46) (mt-ccp-bn)

\section{References:}

Monteiro et al. (2008); Moreto et al. (2011); de Melo et al. (2017); de Freitas Toledo et al. (2019); de Melo et al. (2019); Craveiro et al. (2020); Pestilho et al. (2020); Previato et al. (2020) 


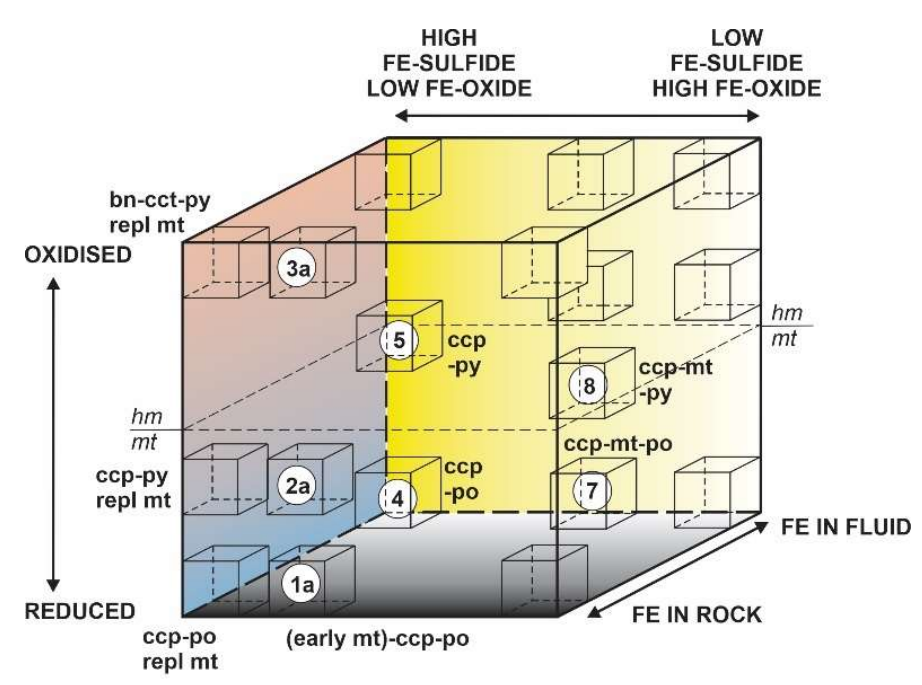

Cloncurry CU-Au-Fe (Co, REE) deposits
(1a) Osborne $\mathrm{Cu}-\mathrm{Au}(\mathrm{Co})$
(2a) Osborne Cu-Au (Co), Starra Cu-Au (Co) early mt-ccp
(3a) Starra late $\mathrm{Au}-\mathrm{Cu}$
(4) Eloise $\mathrm{Cu}-\mathrm{Au}$ (Co), Mt Elliott Cu-Au ((east)
(5) Greenmount Cu-Au (Co)
(7) Monakoff Cu-Au (Co, REE) early, E1N Cu-Au (REE) early
(8) Emest Henry Cu-Au (CO, REE, bar, flu), Mt Elliott (west) \& SWAN Cu-Au (REE),
E1N Cu-Au (REE, late bar, flu), Monakofff Cu-Au (REE, late bar, flu)

References:

Rotherham (1997); Baker \& Laing (1998); Williams \& Skirrow (2000); Baker et al. (2001); Mark et al. (2006); Fisher \& Kendrick (2008); Brown \& Porter (2010); Williams et al. (2015); Case (2016); Cave et al. (2018) 


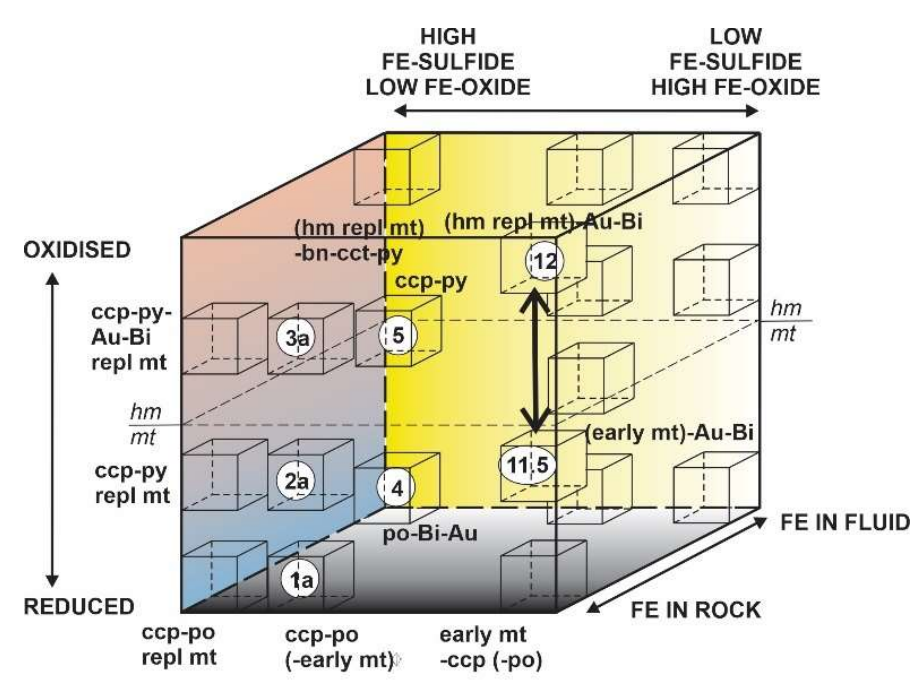

Tennant Creek Cu-Au-Fe (Bi) deposits
1a West Peko Cu-Au-Bi, Warrego Cu-Au-Bi (uncommon po)
(2a) Warrego Cu-Au-Bi, Gecko K44 Cu-Au-Bi (lower), Peko Cu-Au-Bi, Orlando Cu-Au-Bi
3a Gecko K44 Cu-Au-Bi (upper)
(4) West Peko shear-hosted Au-Bi outside ironstone
(5) Orlando East, Gecko (Monitor, Goanna), Bishop Creek Cu-Au-Bi
(12) Eldorado, Nobles $\mathrm{Nob}$ (?) Au (-Bi)
$11.5 \leftrightarrow 12$ White Devil, Juno, Argo, TC8, Chariot mt-Au-Bi (variable hm, py, Cu)

References:

Large (1975); Wedekind et al. (1989); Skirrow (1993, 2000); Huston et al. (1993); Skirrow \& Walshe (2002) 


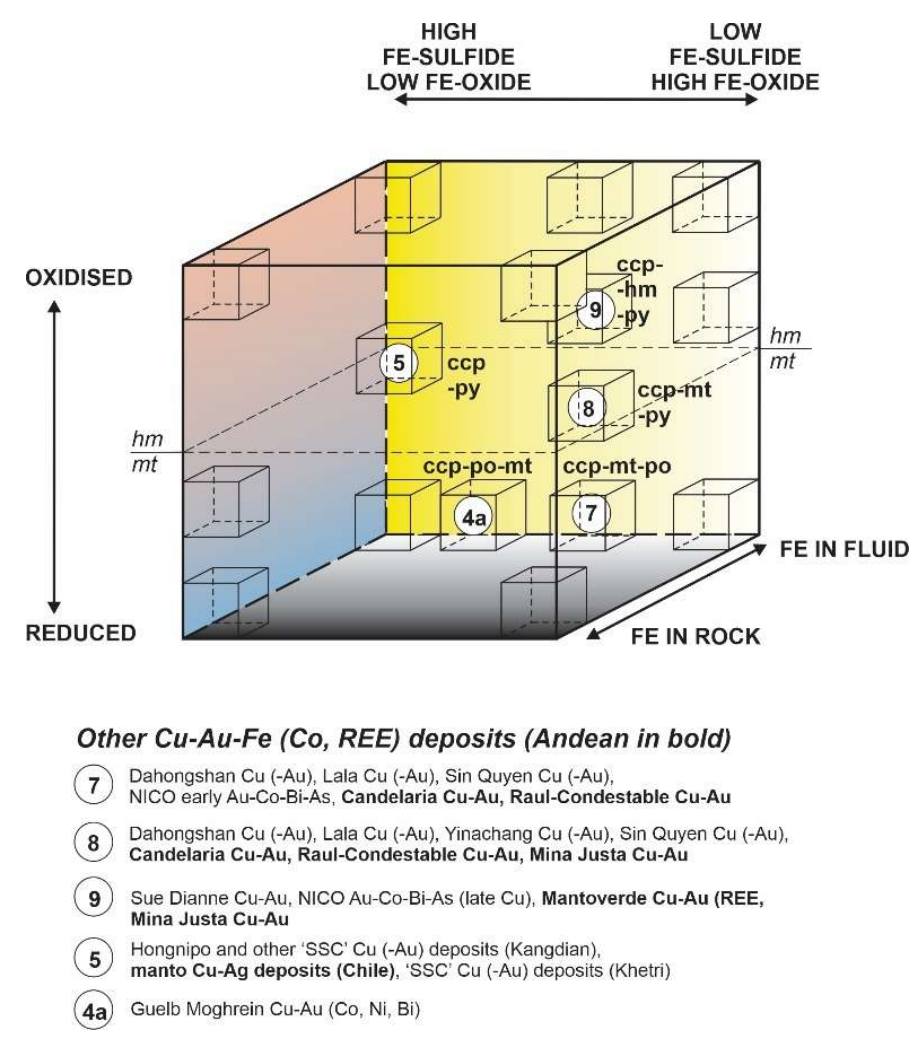

References:

Andes: Hopper \& Correa (2000); Marschik \& Fontboté (2001); Boric et al. (2002); Maksaev \& Zentilli (2002); de Haller et al. (2006); Ramírez et al. (2006); Benavides et al. (2007); Chen et al. (2010); Rieger et al. (2010); del Real et al. (2018)

Kangdian: Zhao \& Zhou (2011); Chen \& Zhou (2012); Zhou et al. (2014); Li et al. (2015); Zhao et al. (2017); Lin et al. (2020)

Great Bear magmatic zone: Goad et al. (2000); Acosta-Góngora et al. (2015)

Geulb Moghrein: Kolb et al. (2010); Kirschbaum \& Hitzman (2016); Kolb \& Petrov (2016) 
Appendix 3. Summary of deposits extracted from the OSNACA global ore geochemical data base (Brauhart \& Hagemann, 2020) and attributed as IOCG deposits. Sub-types assigned in the present study are based on descriptions in OSNACA together with information from published literature for individual deposits, and correspond to variants in the CGI cube (Figs. 7, 8). Data for several additional deposits are sourced as indicated. The number of samples in OSNACA for each deposit (\# samples) differs in some cases from the number of samples plotted in the figures in this contribution (\# plotted) due to exclusion of samples of host rock; only ore samples have been used in this study.

\begin{tabular}{|c|c|c|c|c|c|c|c|c|c|c|}
\hline \multicolumn{4}{|c|}{ OSNACA and additional ore geochemistry data set } & \multirow[b]{2}{*}{ \# samples } & \multirow[b]{2}{*}{$\begin{array}{l}\text { OSNACA } \\
\text { d class }\end{array}$} & \multirow[b]{2}{*}{ Sub-type (this study) } & \multirow[b]{2}{*}{ Notes } & \multirow[b]{2}{*}{ Source } & & \\
\hline Deposit name & Country & State & Metall. Prov. & & & & & & & \\
\hline Kanmantoo & Australia & South Australia & Adelaide Fold Belt & 2 & 2 IOCG & Reduced-low mt & possible ISCG? & OSNACA & & \\
\hline Antas & Brazil & Pará & Carajass & 1 & 1 IOCG & Reduced - variable mt & & OSNACA & & \\
\hline Sossego & Brazil & Pará & Carajás & 3 & 31006 & Intermed-redox - mt-rich & & OSNACA & & \\
\hline Barreal Seco & Chile & Atacama & Chilean Iron Belt & 3 & 31006 & Oxidised-hm-rich (Andes) & & OSNACA & & \\
\hline Candelaria & Chile & Atacama & Chilean Iron Belt & 2 & 2 IOCG & Reduced-variable $\mathrm{mt}$ & & Marschik \& & Fontboté ( & (2001) \\
\hline Carola & Chile & Atacama & Chilean Iron Belt & 3 & 31006 & Intermed-redox - hm-mt or mt-hm-rich & & Marschik \& & Fontboté & (2001) \\
\hline Manto Verde & Chile & Atacama & Chilean Iron Belt & 5 & 5 IOCG & Oxidised-hm-rich (Andes) & & Rieger et al. & 14. $(2010)$ & \\
\hline Socavon Rampa & Chile & Atacama & Chilean Iron Belt & 2 & 21006 & Oxidised-hm-rich (Andes) & & OSNACA & & \\
\hline Artemis & Australia & Queensland & Cloncurry & 6 & 4 IOCG & Reduced-low mt & Zn-Pb-rich & OSNACA & & \\
\hline Barbara & Australia & Queensland & Cloncurry & 8 & $610 C G$ & Reduced - low mt & & OSNACA & & \\
\hline Blackard & Australia & Queensland & Cloncurry & 2 & 1 IOCG & Cu-Au & oxidation \& Fe ox unknown & OSNACA & & \\
\hline Cameron River & Australia & Queensland & Cloncurry & 9 & $810 C 6$ & Reduced - low mt & & OSNACA & & \\
\hline Canteen & Australia & Queensland & Cloncurry & 4 & 41006 & Reduced - low mt & Fe ox unknown & OSNACA & & \\
\hline E1 & Australia & Queensland & Cloncurry & 10 & 10 IOCG & Intermed-redox - hm-mt or mt-hm-rich & & OSNACA & & \\
\hline Eloise & Australia & Queensland & Cloncurry & 7 & 71006 & Reduced - variable mt & & OSNACA & & \\
\hline Ernest Henry & Australia & Queensland & Cloncurry & 12 & $12 \mathrm{IOCG}$ & Intermed-redox - hm-mt or mt-hm-rich & & OSNACA & & \\
\hline Great Australia & Australia & Queensland & Cloncurry & 2 & $2100 \mathrm{C}$ & Cu-Au & Fe ox unknown & OSNACA & & \\
\hline Kalman & Australia & Queensland & Cloncurry & 3 & 31006 & Intermed? Cu-Au & Fe ox unknown & OSNACA & & \\
\hline Kulthor & Australia & Queensland & Cloncurry & 3 & 31006 & Reduced-variable $\mathrm{mt}$ & & OSNACA & & \\
\hline Kurilla & Australia & South Australia & Cloncurry & 2 & $2100 \mathrm{G}$ & unknown & & OSNACA & & \\
\hline Little Eva & Australia & Queensland & Cloncurry & 2 & 2 IOCG & Oxidised-hm-rich & & OSNACA & & \\
\hline Lorena & Australia & Queensland & Cloncurry & 1 & 1 IOCG & Reduced - low mt & & OSNACA & & \\
\hline Merlin & Australia & Queensland & Cloncurry & 4 & 4 IOCG & & no Fe ox, not Cu-Au-Fe ( $\mathrm{Co}, \mathrm{REE})$ deposit & OSNACA & & \\
\hline Monakoff & Australia & Queensland & Cloncurry & 7 & 7 IOCG & Intermed-redox & hybrid? & OSNACA & & \\
\hline Mount Colin & Australia & Queensland & Cloncurry & 5 & 31006 & Cu-Au & oxidation and Fe-ox unknown & OSNACA & & \\
\hline Mount Elliot & Australia & Queensland & Cloncurry & 1 & 1 locG & Intermed-redox - mt-rich & & OSNACA & & \\
\hline Osborne & Australia & Queensland & Cloncurry & 13 & 12 IOCG & Reduced - variable $\mathrm{mt}$ & & OSNACA & & \\
\hline Rocklands & Australia & Queensland & Cloncurry & 3 & 31006 & Intermed-redox - low Fe-ox & & OSNACA & & \\
\hline Starra & Australia & Queensland & Cloncurry & 6 & 4 IOCG & Intermed-redox - hm-mt or mt-hm-rich & & OSNACA & & \\
\hline Swan & Australia & Queensland & Cloncurry & 8 & $810 \mathrm{G}$ & Intermed-redox - mt-rich & & OSNACA & & \\
\hline Trekelano & Australia & Queensland & Cloncurry & 2 & 1 10cG & Cu-Au & oxidation and Fe-ox unknown & OSNACA & & \\
\hline Olympic Dam & Australia & South Australia & Gawier Craton & 6 & $6100 \mathrm{G}$ & Oxidised-hm-rich & & OSNACA & & \\
\hline Prominent Hill & Australia & South Australia & Gawler Craton & 3 & $3100 \mathrm{G}$ & Oxidised-hm-rich & & OSNACA & & \\
\hline Wheal Hughes & Australia & South Australia & Gawier Craton & 2 & 21006 & Intermed-redox - low Fe-ox & & OSNACA & & \\
\hline Guelb Moghrein & Mauritanic & Elnchiri & Guelb Moghrein & 2 & $2100 \mathrm{G}$ & Reduced-low mt & & OSNACA & & \\
\hline Khetri & India & Rajasthan & Khetri & 2 & $2100 \mathrm{G}$ & Intermed-redox - mt-rich & & OSNACA & & \\
\hline Messina & South Afric & ¿Limpopo & Limpopo & 3 & 31006 & unknown & not Cu-Au-Fe (Co, REE) deposit? & OSNACA & & \\
\hline Vergenoeg & South Afric & ¿Limpopo & Limpopo & 1 & $110 \mathrm{CG}$ & & magnetite-fluorite, not Cu-Au-Fe (Co, REE) de & ESNACA & & \\
\hline Sin Quyen & Vietnam & Lào Cai & Red River Fault Zone & 1 & $1100 \mathrm{Cg}$ & Intermed-redox & mag rich & OSNACA & & \\
\hline Gecko & Australia & Northern Territory & Tennant Creek & 2 & 21006 & Intermed-redox - hm-mt or mt-hm-rich & & OSNACA & & \\
\hline Warrego & Australia & Northern Territory & Tennant Creek & 3 & 3 IOCG & Intermed-redox - mt-rich & & OSNACA & & \\
\hline White Devil & Australia & Northern Territory & Tennant Creek & 3 & 31006 & Intermed-redox - mt-rich & & OSNACA & & \\
\hline Wernecke Mtn & Canada & Yukon & Wernecke & 1 & 1 IOCG & Intermed-redox - low Fe-ox & & OSNACA & & \\
\hline
\end{tabular}




\section{Supplementary Information}

\section{Iron oxide copper-gold (IOCG) deposits - a review (part 1): settings, mineralogy, ore geochemistry, and classification within the $\mathrm{Cu}-\mathrm{Au}-\mathrm{Fe}$ ( \pm Co, REE) deposit family}

Roger G. Skirrow

\section{Geological settings and characteristics of provinces hosting $\mathrm{Cu}-\mathrm{Au}-\mathrm{Fe}$ including IOCG deposits}

\section{Introduction}

The timing of regional geological events in relation to $\mathrm{Cu}-\mathrm{Au}-\mathrm{Fe}$ mineralisation is summarised in Figure S1 for six of the world's major metallogenic provinces containing large IOCG deposits and for which comprehensive geochronological data are also available. Event time spans shown in Figure S1 represent the main bodies of available geochronological data for each event, with emphasis on ages determined with robust geochronometers such as U-Pb and $\mathrm{U}-\mathrm{Th}-\mathrm{Pb}$ isotope analyses of zircon, titanite and monazite, and Re-Os isotope analysis of molybdenite. Additional constraints from ${ }^{40} \mathrm{Ar} /{ }^{39} \mathrm{Ar}$ dating have been utilised for hydrothermal minerals in some provinces. Uncertainties on individual ages are given in the detailed descriptions below and in the accompanying figures in some cases. The timing and character of deformation/tectonism events have been largely taken from the literature, supplemented by further interpretation in some provinces as described below. 


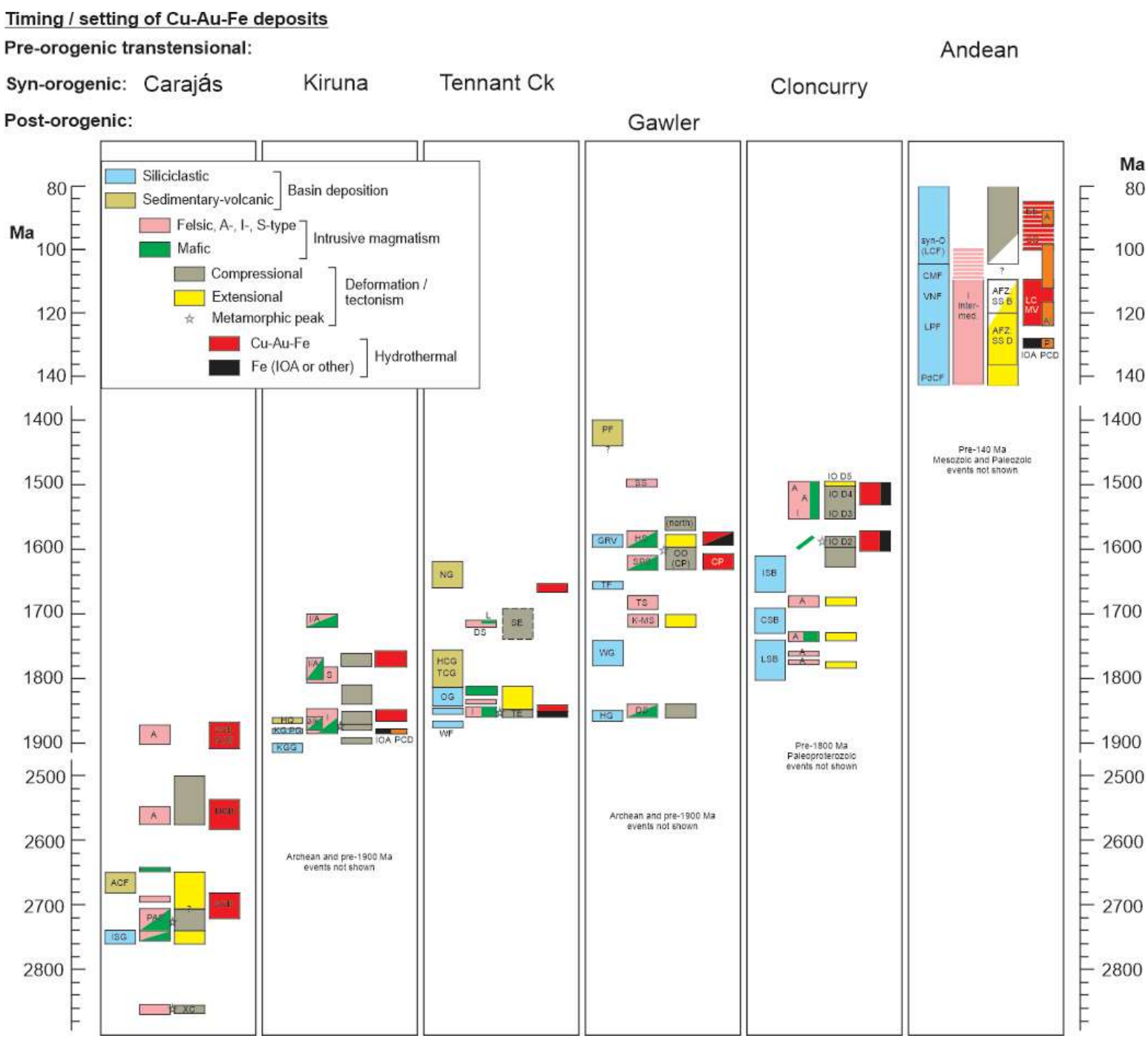

Figure S1. Synthesis of geochronological data for mineralisation, tectonic, magmatic and supracrustal depositional events in key provinces with $\mathrm{Cu}-\mathrm{Au}-\mathrm{Fe}$ ( $\pm \mathrm{Co}$, REE) including IOCG deposits. The Kiruna/Norbotten and Andean provinces also contain well known IOA deposits. Note breaks in time scale. For sources of data see the Supplementary Information. Abbreviations for intrusive magmatism: A - A-type granites, I - I-type, S - S-type, alk - alkaline. Abbreviations of rock units: Carajás province, ACF - Águas Claras Formation, ISG - Itacaiunas Supergroup, NCB - Northern Copper Belt, PAS - Planalto Suite, SCB Southern Copper Belt, XC - Xingu and Pium Complexes; HQ - Hauki Quartzite, IOA - iron oxide apatite deposits, Kiruna province, KGG - Kiruna Greenstone Group, KG - Kiirunavaara Group, PCD - porphyry Cu deposit; Tennant Creek, DS - Devils Suite, HCG - Hatches Creek Group, OG - Ooradidgee Group, NG Namerinni Group, SE - Strangways Event, TCG - Tennant Creek Granite suite, TE - Tennant Event, WF Warramunga Formation; Gawler Craton - CP - Curnamona Province Cu-Au deposits, DS - Donnington Suite, GRV - Gawler Range Volcanics, HG - Hutchison Group, HS - Hiltaba Suite, K-MS - Kimban-Moody Suite, 00 (CP) - Olarian Orogeny in Curnamona Province, SPS - St Peter Suite, TF - Tarcoola Formation, TS- Tunkillia Suite, WG - Wallaroo Group; Cloncurry province, CSB - Calvert Superbasin, IO - Isan Orogeny, ISB - Isan Superbasin, LSB - Leichardt Superbasin; Andean province (Chile; formation names after Boyce et al., 2020), A - Carmen de Andacollo porphyry Cu deposit, AFZ - Atacama Fault Zone, CMF - Cerro Morado Formation, EE - El Espino $\mathrm{Cu}-\mathrm{Au}$-Fe deposit, IOA - iron oxide apatite deposits, LC - La Candelaria, LPF - Lo Prado Formation, MV - Mantoverde deposit, P - Productora Cu-Au deposit, PdCF - Punta del Cobre Formation, PCD - porphyry Cu deposits, SS B - strike-slip brittle, SS D - strike-slip ductile, syn-O (LCF) - syn-orogenic Las Chilcas Formation, VNF - Veta Negra Formation. 


\section{Carajás province, Brazil - Neoarchean $\mathrm{Cu}-\mathrm{Au}-\mathrm{Fe}$ and Paleoproterozoic $\mathrm{Cu}-\mathrm{Au}$ deposits}

The Carajás metallogenic province in the southeastern part of the Amazon Craton hosts some of the world's largest and most important iron oxide-rich $\mathrm{Cu}-\mathrm{Au}$ deposits, including the Salobo, Cristalino, Sequeirinho (part of the Sossego group of deposits) and Igarapé Bahia deposits (Grainger et al., 2008; Xavier et al., 2010; Schutesky \& de Oliveira, 2020; Trunfull et al., 2020). Dating of the deposits shows that $\mathrm{Cu}-\mathrm{Au}$ mineralisation in the Southern Copper Belt (e.g. Cristalino, Sossego) commenced at $\sim 2720-2680$ Ma whereas in the Northern Copper Belt (including Salobo and Igarapé Bahia) the available data indicate a major $\mathrm{Cu}-\mathrm{Au}$ event at $\sim 2580$ 2535 Ma (Fig. S1; Re-Os molybdenite and U-Pb monazite, titanite, zircon ages - Machado et al., 1991; Requia et al., 2003; Tallarico et al., 2005; Moreto et al., 2015a, 2015b; Pollard et al., 2019). Many deposits also record younger U-Pb and ${ }^{40} \mathrm{Ar}-{ }^{39} \mathrm{Ar}$ ages (e.g. $2497 \pm 5 \mathrm{Ma}, \mathrm{U}-\mathrm{Pb}$ titanite age at Salobo - Machado et al., 1991), reflecting the complex and prolonged tectonothermal history of the Carajás Province. Indeed a third period of $\mathrm{Cu}-\mathrm{Au}$ mineralisation is believed to have occurred at 1900-1860 Ma in both the Southern and Northern Copper Belts (Fig. S1; e.g. Alvo 118, Estrela, Sossego-Curral, Breves, and Gameleira deposits - Tallarico et al., 2005; Moreto et al., 2015a, 2015b; Pollard et al., 2019). Although many of these relatively small Paleoproterozoic $\mathrm{Cu}-\mathrm{Au}$ deposits were initially described as IOCG deposits, Pollard et al. (2019) noted their anomalous BBe-Bi-Li-Sn-W geochemistry and distinguished these Fe-oxide-poor, quartz \pm carbonate-rich deposits as separate in origin from the Neoarchean IOCG deposits and proposed a magmatichydrothermal derivation related to A-type granites of overlapping age. The Carajás Province is also endowed with large deposits of Fe related to banded iron formations, Mn, Cr-PGE and Ni associated with mafic intrusions (e.g. Luanga deposit), and hydrothermal Au and Au-PGE deposits (e.g. Serra Pelada; Diella et al., 1995; Grainger et al., 2008; Bettencourt et al., 2016).

The Neoarchean IOCG and Paleoproterozoic $\mathrm{Cu}-\mathrm{Au}$ deposits all occur within the Carajás Domain, which forms the northern part of the Carajás Province. The Southern Copper Belt lies along the regional shear zone system bounding the Carajás Domain with the Rio Maria Domain to the south, which is dominated by 3066-3000 Ma basement rocks of the Xingu Complex and Pium Complex (Pidgeon et al., 2000; Moreto et al., 2011). The latter were deformed and metamorphosed at high grade at $\sim 2860 \mathrm{Ma}$ (Machado et al., 1991). Several of the Neoarchean $\mathrm{Cu}-\mathrm{Au}$ deposits occur within a few kilometres of the domain boundary, hosted by the $\sim 3.0 \mathrm{Ga}$ basement and syn-orogenic $\sim 2860$ Ma granitoids (e.g., Bacuri - Moreto et al., 2011), and a few others occur within the Xingu Complex in the Northern Copper Belt (e.g. Salobo, de Melo et al., 2017). However, the majority of the Neoarchean $\mathrm{Cu}-\mathrm{Au}$ deposits are hosted by the overlying $2760-2730$ Ma Itacaiúnas Supergroup which comprises lower greenschist to amphibolite facies metamorphosed mafic and felsic volcanic rocks, iron formations and clastic sedimentary rocks (Machado et al., 1991; Olszewski et al., 1989). The $\sim 2720-2680$ Ma timing of many of the major $\mathrm{Cu}-\mathrm{Au}$ deposits and regional sodic alteration in the Southern Copper Belt appears to postdate regional ductile transpressional tectonism $(\sim 2780-2740 \mathrm{Ma})$ and extensive $\sim 2740 \mathrm{Ma}$ bimodal intrusive magmatism (Moreto et al., 2015b), but overlaps with the alkaline and A-type Planalto Granite Suite and possibly co-magmatic gabbros (Fig. S1; $2706 \pm 5$ Ma to $2754 \pm 2$ Ma, Feio et al., 2013). In detail, however, most of the Neoarchean $\mathrm{Cu}-\mathrm{Au}-\mathrm{Fe}$ mineralisation in the Southern Copper Belt formed during brittle-ductile and brittle deformation associated with shear zones and faults (e.g. Sequeirinho orebody - Sossego deposit; Cristalino deposit; Bacuri and Bacaba prospects; Monteiro et al., 2008; Xavier et al., 2010; Moreto et al., 2015a, 2015b; Craveiro et al., 2020; Pestilho et al., 2020). This deformation controlling $\mathrm{Cu}-\mathrm{Au}-\mathrm{Fe}$ mineralisation in the Southern Copper Belt may be linked to the switch from sinistral transpressional to dextral transtensional deformation that has been identified at 2725-2700 within the Carajás and Cinzento shear zones to the north within the Carajás Domain (Xavier et al., 2010; Moreto et al., 2015b; de Melo et al., 2017; de Freitas Toledo et al., 2019). Regional transtensional deformation may have continued in some shear zones until $\sim 2600$ Ma when there was a further period of transpression and mylonite development in the Carajás Domain (Xavier et al., 2010; Moreto et al., 2015b). Also of note is the 
deposition of the low metamorphic grade and siliciclastic Águas Claras Formation after 2681 Ma (detrital zircon maximum depositional age, Trendall et al., 1998) and before intrusion of 2645 Ma gabbro into the sequence (Fig. 1; Dias et al., 1996). This extensive basin in the Carajás Domain could be interpreted to indicate a continuation of extensional tectonism after formation of the earlier group of major Neoarchean $\mathrm{Cu}-\mathrm{Au}-\mathrm{Fe}$ deposits in the Southern Copper Belt but prior to the second group of major $\mathrm{Cu}-\mathrm{Au}-\mathrm{Fe}$ deposits in the Northern Copper Belt.

Available geochronology indicates that formation of the younger Neoarchean copper-gold deposits in the Northern Copper Belt at $2580-2535$ Ma (Fig. S1) could have been coeval with emplacement of uncommon A-type felsic intrusions of similar age such as the Old Salobo Granite (2573 $\pm 2 \mathrm{Ma}$, Machado et al., 1991; 2550 Ma, de Melo et al., 2017), as proposed by Tallarico et al. (2005). In any case, copper-gold mineralisation at the Salobo deposit appears to have been synchronous with ductile and/or brittle-ductile deformation at medium to low grade metamorphic conditions $\left(\sim 650^{\circ} \mathrm{C}\right.$ to $\left.<350^{\circ} \mathrm{C}\right)$ within the multiply-reactivated Cinzento Shear Zone (Souza \& Vieira, 2000; de Melo et al., 2017). To the west of Salobo along the Cinzento Shear Zone, a syn-deformational setting also has been reported for the Igarapé Cinzento (Alvo GT46) $\mathrm{Cu}-\mathrm{Au}-\mathrm{Fe}$ deposit, although here breccia-hosted mineralisation is controlled by brittle-ductile faults cross-cutting the Cinzento Shear Zone (Xavier et al., 2010; de Freitas Toledo et al., 2019). Breccias also host the Igarapé Bahia (including Alemão) $\mathrm{Cu}-\mathrm{Au}-\mathrm{Fe}$ deposit near the Carajás Fault $\sim 25 \mathrm{~km}$ south of the Salobo deposit, where breccia fragments and $\mathrm{Cu}$-sulfidic matrix in some cases exhibit a tectonic foliation (Ronzê et al., 2000). The Gameleira $\mathrm{Cu}$-Au deposit, $\sim 30 \mathrm{~km}$ southeast of Salobo along the Cinzento Shear Zone, is a possible example of Neoarchean $\mathrm{Cu}-\mathrm{Au}-$ Fe mineralisation overprinted by Paleoproterozoic $\mathrm{Cu}$-Au ore. Texturally early banded quartzgrunerite-magnetite rock with Cu sulfides $(2614 \pm 14 \mathrm{Ma}$, Re-Os molybdenite age, Marschik et al., 2005 ) is cut by vein networks of quartz, biotite, Cu-sulfides, and minor REE, F, Co, Ni, and B minerals dated at $1908 \pm 7 \mathrm{Ma}\left({ }^{40} \mathrm{Ar}-{ }^{39} \mathrm{Ar}\right.$ biotite, Pollard et al., 2019). Another example is the Sossego-Curral orebody (1879 \pm 4 to $1904 \pm 5 \mathrm{Ma}$, U-Pb monazite, Moreto et al., 2015a) which lies $<1 \mathrm{~km}$ east of the Neoarchean Fe-oxide-rich Sequeirinho orebody of the Sossego deposit. Similar ages have been reported for other $\mathrm{Cu}-\mathrm{Au}$ vein-type and breccia-hosted deposits lacking significant iron oxides in the Carajás Domain, including Alvo 118 (1869 $\pm 7 \mathrm{Ma}, \mathrm{U}-\mathrm{Pb}$ xenotime, Tallarico, 2003; $1885 \pm 4 \mathrm{Ma},{ }^{40} \mathrm{Ar}-{ }^{-39} \mathrm{Ar}$ biotite, Pollard et al., 2019), Breves (1886 $\pm 5 \mathrm{Ma},{ }^{40} \mathrm{Ar}-$ ${ }^{39} \mathrm{Ar}$ biotite, Pollard et al., 2019), and Estrela (1896 $\pm 7 \mathrm{Ma},{ }^{40} \mathrm{Ar}-{ }^{39} \mathrm{Ar}$ biotite, Pollard et al., 2019). These ages overlap with the $\sim 1880 \mathrm{Ma}$ ages of several A-type granites identified in the Carajás Domain (Machado et al., 1991; Moreto et al., 2015b), although a close spatial association (e.g. <2 $\mathrm{km}$ ) with the $\sim 1900-1860 \mathrm{Ma} \mathrm{Cu}-\mathrm{Au}$ deposits is only apparent at Gameleira (cf. Pollard et al., 2019 ) and possibly at the Sossego-Curral orebody which is situated $>4 \mathrm{~km}$ from a large $\sim 1880$ Ma granite (Moreto et al., 2015a).

\section{Guelb Moghrein Cu-Au deposit, Mauritania - Neoarchean/Paleoproterozoic}

The Guelb Moghrein Cu-Au deposit (57.7 Mt of sulfide ore @ $1.15 \% \mathrm{Cu}, 0.69 \mathrm{~g} / \mathrm{t}$ Au plus 9.6 Mt of oxide ore) is hosted mainly by metacarbonate rocks within a package of dominantly meta-mafic igneous rocks, metacarbonate, banded iron formation and felsic meta-volcanic rocks (Kolb et al., 2010; Kirschbaum \& Hitzman, 2016; Kolb \& Petrov, 2016). Although no geochronology is available for the host rocks, and proximal igneous intrusive rocks are not evident at the Guelb Moghrein deposit (Kolb et al., 2010), some of the coarse grained amphibolites have been interpreted as meta-gabbros. A volcanic arc setting of magmatism was proposed by Kolb et al. (2008). Early sodic and distal biotite alteration of amphibolites within and adjacent to shear zones, and siderite development, were succeeded by grunerite-cummingtonite-magnetitegraphite alteration and then $\mathrm{Cu}-\mathrm{Fe}$ sulfide and Au mineralisation (Kolb et al., 2010; Kirschbaum \& Hitzman, 2016; Kolb \& Petrov, 2016). An age of $2492 \pm 9$ Ma has been reported for hydrothermal monazite and xenotime associated with chalcopyrite and pyrrhotite (Meyer et al., 
2006). Much of the $\mathrm{Cu}-\mathrm{Au}$ mineralisation is hosted by breccias attributed to a regional D2 thrusting and shearing event at upper greenschist facies conditions, which overprinted an earlier thrusting event at amphibolite facies conditions (Kolb et al., 2010). Alteration and $\mathrm{Cu}-\mathrm{Au}$ mineralisation therefore can be described as post-peak metamorphic and synchronous with compressional deformational. A later hydrothermal event at lower greenschist facies conditions resulted in magnesian metasomatism (chlorite, anthophyllite, talc) and has been dated at $1742 \pm$ $12 \mathrm{Ma}$ (Meyer et al., 2006).

\section{Kiruna province, Sweden - Paleoproterozoic IOA and Cu-Au-Fe deposits}

The Archean to Paleoproterozoic northern Fennoscandian shield in northern Sweden, Finland and Russia hosts a range of mainly Paleoproterozoic $\mathrm{Fe}, \mathrm{Cu}, \mathrm{Au}, \mathrm{Ni}$ and $\mathrm{Zn}$ deposits (Billström et al., 2010; Martinsson et al., 2016). Best known for its large Fe deposits such as the Kiirunavaara iron oxide-apatite (IOA) deposit at Kiruna township, the Norbotten region of northern Sweden also contains the large porphyry style Aitik Cu-Au-Ag (-Mo) deposit (500 Mt @ 0.4\% Cu, 0.2 g/t $\mathrm{Au}$, Wanhainen et al., 2005; Wanhainen \& Martinsson, 2010), several small $\mathrm{Cu}-\mathrm{Au}-\mathrm{Fe}$ deposits described as IOCG deposits, skarn-related Fe deposits, and stratabound to stratiform $\mathrm{Cu}-\mathrm{Zn}-\mathrm{Pb}$ volcanic-hosted deposits such as the Viscaria $\mathrm{Cu}$-Zn deposit (Weihed et al., 2005; Billström et al., 2010; Martinsson et al., 2016). There are also a diverse range of 'epigenetic $\mathrm{Au}$ and $\mathrm{Cu}-\mathrm{Au}$ ' deposits including orogenic Au deposits that extend across northern Fennoscandia from the Norbotten region to the Central Lapland region of Finland (Billström et al., 2010).

The northern Fennoscandian shield is an important example of a metallogenic province with both IOA and $\mathrm{Cu}-\mathrm{Au}-\mathrm{Fe}$ deposits including IOCG deposits, and where sufficient new geochronology data are available to constrain their relative timing. Five key events can be recognised during the period $\sim 1890 \mathrm{Ma}$ to $\sim 1750 \mathrm{Ma}$ (Fig. S2, right side, E1-E5), representing early magmatism and IOA and porphyry-style $\mathrm{Cu}-\mathrm{Au}(-\mathrm{Mo})$ mineralisation, a regional tectonothermal event, a period of initial $\mathrm{Cu}-\mathrm{Au}-\mathrm{Fe}$ mineralisation, further tectonism and magmatism, and a second period of $\mathrm{Cu}-\mathrm{Au}-$ Fe mineralisation. While many of these events have been previously recognised (e.g. Bergman et al., 2001; Billström et al., 2010; Martinsson et al., 2016), the recent new geochronological data allows some further refinement of the metallogenic evolution. The following descriptions summarise the geological setting and key metallogenic features of each event. 


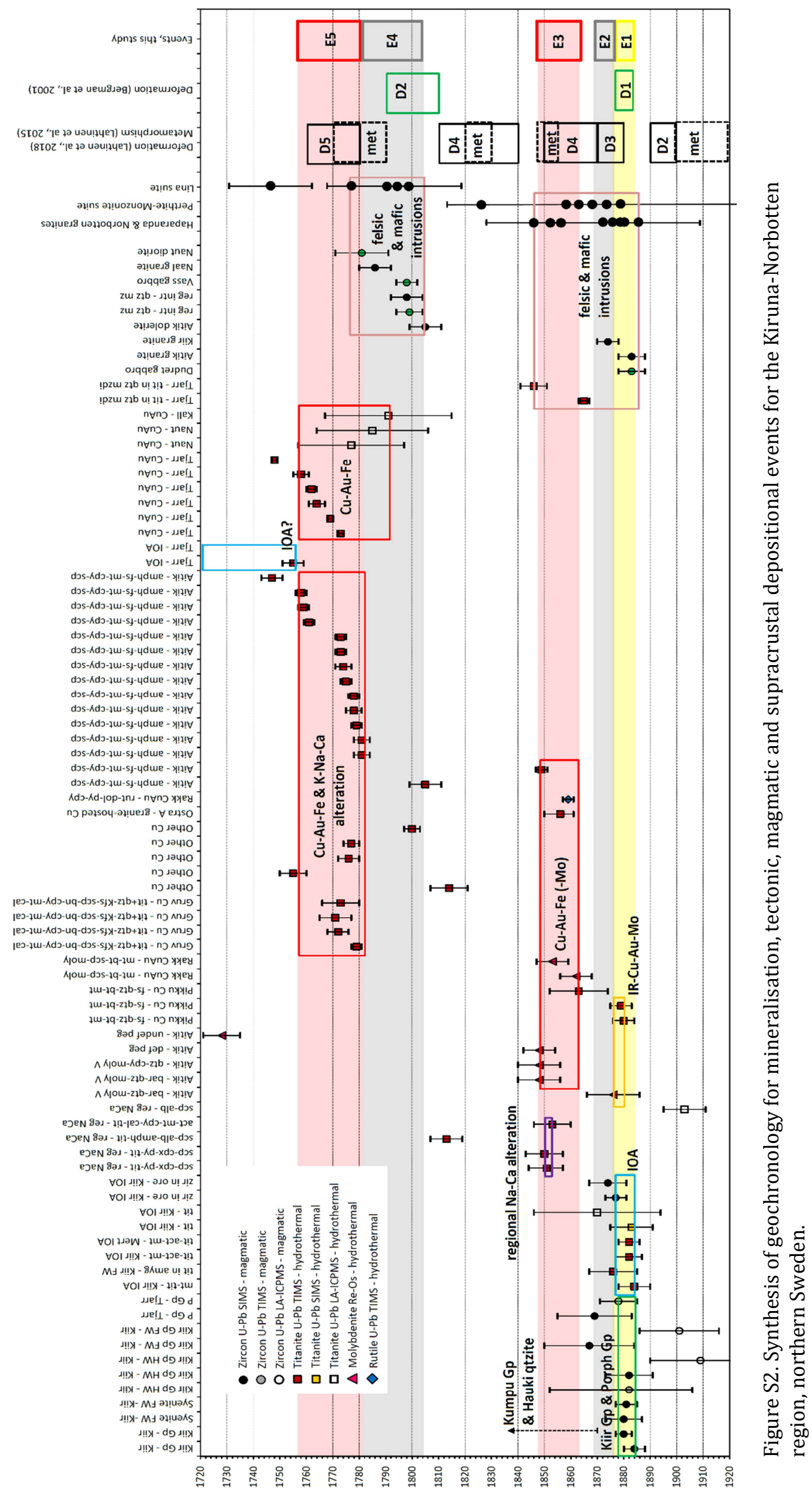


Archean basement is overlain by 2.50-1.96 Ga supracrustal rocks and mafic-ultramafic intrusions mainly in Finland and also in the Kiruna district where they are known as the Kovo Group and Kiruna Greenstone Group. These predominantly mafic-ultramafic to intermediate volcanic sequences with lesser mafic tuff, black schist and minor carbonate units are unconformably overlain by volcanic and sedimentary rocks of the Kurravaara Conglomerate, Porphyrite Group (mainly calc-alkaline mafic-intermediate volcanic rocks) and the Kiirunavaara Group (mainly alkaline intermediate to felsic volcanic rocks; Billström et al., 2010; Martinsson et al., 2016. Earlier and recently available high quality zircon U-Pb geochronology indicates deposition of these supracrustal rocks mainly at 1884-1878 Ma (Fig. S2; Welin, 1987; Edfelt et al., 2006; Westhues et al., 2016; Billström et al., 2019). The unconformably overlying Hauki and Maatavaara quartzites in the Norbotten region are stratigraphically equivalent to the epiclastic-dominated Kumpu Group in Finland (Billström et al., 2010) which has a maximum depositional age of 1870 Ma (Fig. S2; Köykkä et al., 2019). Calc-alkaline felsic and mafic intrusions of the Haparanda suite were emplaced from $\sim 1886$ Ma to $\sim 1872$ Ma with a possible later phase at $\sim 1856-1846$ Ma (Fig. S2); the initial phases may be co-magmatic with the Porphyrite Group volcanics (Martinsson et al., 2016). The temporally overlapping but partly later and compositionally separate PerthiteMonzonite suite (1882-1860 Ma, Fig. S2; Bergman et al., 2001; Westhues et al., 2016; Sarlus et al., 2018) may be co-magmatic with the alkaline Kiirunavaara Group volcanics (Martinsson et al., 2016).

Previous workers recognised a major metallogenic event at 1920-1870 Ma (Billström et al., 2010) or 1890-1880 Ma (Martinsson et al., 2016) when major IOA deposits together with porphyry style $\mathrm{Cu}-\mathrm{Au}(-\mathrm{Mo})$ and IOCG deposits formed coevally with calc-alkaline and/or alkaline volcanic and intrusive magmatism. A second epigenetic $\mathrm{Cu}-\mathrm{Au}$ event was also recognised at 18501790 Ma (Billström et al., 2010) or $\sim 1780$ Ma (Martinsson et al., 2016). Building on this broad temporal framework we interpret the currently available geochronological data to indicate a first event at 1884-1876 Ma., labelled E1 in Figure S2, when major IOA deposits and porphyry-style $\mathrm{Cu}-\mathrm{Au}(-\mathrm{Mo})$ deposits formed contemporaneously with the Porphyry Group and Kiirunavaara Group volcanic host rocks of the IOA deposits and associated syenitic subvolcanic intrusions (Romer et al., 1994; Martinsson et al., 2016; Westhues et al., 2016; Billström et al., 2019). The porphyry-style deposits evidently are uncommon yet include the large Aitik $\mathrm{Cu}-\mathrm{Au}-\mathrm{Ag}$ (Mo) deposit.

Previous workers have proposed a major regional deformation and metamorphic event, the Svecofennian orogeny, at $1880 \mathrm{Ma}$ (Bergman et al., 2001). According to Martinsson et al. (2016) this event occurred between volcanism of the Porphyrite and Kiirunavaara groups. However, Lahtinen et al. (2018) proposed a regional compressive tectonic event (D3) at 1880-1870 Ma across northern Fennoscandia, which would largely postdate volcanism of the Porphyrite and Kiirunavaara groups as well as IOA and porphyry-style $\mathrm{Cu}-\mathrm{Au}$ mineralisation. This reasonable geological scenario is consistent with the documented geology and geochronology for the Norbotten region. Accordingly, we tentatively propose that this D3 'Svecofennian' tectonothermal event of Lahtinen et al. (2018) occurred at $1876-1870 \mathrm{Ma}$ in the Norbotten region, and postdated volcanism, IOA and porphyry $\mathrm{Cu}$-Au formation (Fig. S2, event E2).

The oldest dated $\mathrm{Cu}-\mathrm{Au}$ deposit with abundant co-genetic iron oxides and other typical features of IOCG deposits is the Rakkurijarvi deposit, where Re-Os ages of $1862 \pm 6 \mathrm{Ma}$ and $1853 \pm 6 \mathrm{Ma}$ have been reported for molybdenite associated with magnetite (Smith et al., 2007, 2010), well supported by a U-Pb age of $1859 \pm 2$ Ma for hydrothermal rutile in chalcopyrite-carbonatebearing veins (Martinsson et al., 2016). Similar ages have been published for Cu-bearing mineralisation and alteration at several other deposits including Aitik, Pikkujärvi and Östra Aijäjärvi, as well as for regional Na-Ca alteration (Wanhainen et al., 2005; Martinsson et al., 2016). The overprinting of porphyry-style $\mathrm{Cu}-\mathrm{Au}(-\mathrm{Mo})$ mineralisation at Aitik by IOCG-like hydrothermal assemblages was attributed by Wanhainen \& Martinsson (2010) to events between $\sim 1870 \mathrm{Ma}$ and $\sim 1770 \mathrm{Ma}$. Based on available geochronological data it is suggest here that this 
overprinting may have occurred during two discrete stages of regionally widespread $\mathrm{Cu}-\mathrm{Au}-\mathrm{Fe}$ mineralisation and/or reworking, namely event E3 at $~ 1864-1848 \mathrm{Ma}$ and event E4 at 1805 $1782 \mathrm{Ma}$ (Fig. S2). At Rakkurijarvi breccia-hosted magnetite-rich $\mathrm{Cu}-\mathrm{Au}$ mineralisation is partly hosted by a regional shear zone, with evidence of post-brecciation shear deformation (Smith et al., 2010). Although it is unclear whether initial $\mathrm{Cu}$-Au mineralisation at Rakkurivarvi formed preor syn-shearing, the proposed timing of event E3 is consistent with the $\sim 1870-1850$ Ma regional D4 tectonothermal event described by Lahtinen et al. (2018) and with ductile deformation and metamorphism at $\sim 1860-1850 \mathrm{Ma}$ in the northern Norbotten region and Central Lapland to the east (Bergman et al., 2006; Lahtinen et al., 2015). A few data also indicate that felsic intrusions were emplaced regionally during the E3 event (Fig. S2; e.g. molybdenite-bearing pegmatite at Aitik, Wanhainen et al., 2005; and latest phases of the Haparanda and Perthite-Monzonite suites in northern Norbotten, Bergman et al., 2001, 2006; and the Aalinstunturi suite in Central Lapland, Lahtinen et al., 2018).

Widespread emplacement of the S-type granitic Lina suite occurred across northern Fennoscandia during $\sim 1810-1770 \mathrm{Ma}$, as well as the first phase of the A- and I-type felsic intrusions of the Trans-scandinavian igneous belt (TIB) at 1800 Ma (Fig. S2; Bergman et al., 2001). Recent work in the Norbotten region has also identified significant mafic intrusive activity around this period (Sarlus et al., 2018). Although a regional deformation event was previously recognised at $\sim 1810-1790$ Ma (D2 of Bergman et al., 2001) more recent work has refined the temporal framework so that the D5 event of Lahtinen et al. (2018) postdates the Lina Suite and early TIB magmatism (Fig. S2). This deformation was mainly partitioned into shear zones (Bergman et al., 2006). Timing constraints from U-Pb dating of monazite and zircon overgrowths near the Pajala Shear Zone in northern Norbotten indicate metamorphism at medium to high grades during possibly two stages at $\sim 1830-1820$ Ma and $\sim 1790-1770$ Ma (Fig. S2; Lahtinen et al., 2015). Based on these observations we suggest a thermal event E4 at $\sim 1805-1782 \mathrm{Ma}$ comprising regional felsic and mafic magmatism, and commencement of metamorphism (Fig. S2).

A large number of $\mathrm{U}-\mathrm{Pb}$ ages for hydrothermal titanite within $\mathrm{Na}-\mathrm{Ca}$-, $\mathrm{K}-$ and Fe-rich alteration assemblages and $\mathrm{Cu}-\mathrm{Au}$ mineralisation have been reported for the period $\sim 1800-1750 \mathrm{Ma}$, defining a previously well recognised metallogenic event (e.g. Billström et al., 2010; Martinsson et al., 2016). The data compiled in Figure S2 shows that the titanite ages commence during the latest stages of the regional S-, A- and I-type bimodal magmatism and metamorphism (Bergman et al., 2006; R. Lahtinen et al., 2015), continue through the metamorphic event, and cover a period of regional deformation as documented in the Pajala Shear Zone (D5 of Bergman et al., 2006; Lahtinen et al., 2015, 2018). Accordingly, we refine the timing of this metallogenic event, designated E5, to the period $\sim 1782-1757 \mathrm{Ma}$ (Fig. S2). Given the locally high grade metamorphic conditions (e.g. Bergman et al., 2006) it is unclear whether these titanite ages represent cooling ages, reset ages, and/or formation ages of hydrothermal titanite. The E5 metallogenic event includes relatively small iron oxide-bearing $\mathrm{Cu}-\mathrm{Au}$ deposits such as Tjårrojåkka $\mathrm{Cu}-\mathrm{Au}$ (Edfelt, 2007), Gruvberget $\mathrm{Cu}-\mathrm{Au}$ and Nautanen $\mathrm{Cu}-\mathrm{Au}$ (Martinsson et al., 2016). There are also alteration features of similar age at the Aitik $\mathrm{Cu}-\mathrm{Au}(-\mathrm{Mo})$ deposit (Wanhainen et al., 2005). The significance of two titanite $\mathrm{U}-\mathrm{Pb}$ ages $(1755 \pm 4 \mathrm{Ma}, 1694 \pm 2 \mathrm{Ma})$ from the Tjårrojåkka IOA deposit, which is located $\sim 500 \mathrm{~m}$ southeast of the Tjårrojåkka $\mathrm{Cu}$ deposit (Edfelt, 2007), is unclear. They may record a second relatively minor stage of IOA formation (Edfelt, 2007; Billström et al., 2010), or alternatively may be a consequence of resetting or new titanite growth overprinting an earlierformed IOA deposit. Given the lack of other supporting ages for a second stage of IOA formation, together with metamorphic conditions capable of disturbing titanite U-Pb isotopic systems (e.g. $550-660^{\circ} \mathrm{C}, 1.5-1.8 \mathrm{~kb}$ in the Nautanen area, Sarlus et al., 2018) and the widely reported textural relationships of $\mathrm{Cu}$-Au mineralisation overprinting rather than co-precipitating with IOA mineral assemblages in the Norbotten region (e.g. Billström et al., 2010; Martinsson et al., 2016), a second stage of IOA formation seems unlikely and requires further testing. 
The sequence of events described above for northern Fennoscandia has been explained within the geodynamic context of an evolving continental margin, as recently discussed by Lahtinen et al. $(2015,2018)$ and Lahtinen \& Huhma (2019). Rifting and crustal attenuation of the Karelia continent between $2.44 \mathrm{Ga}$ and $1.98 \mathrm{Ga}$ led to passive margin sedimentation including siliclastics, carbonate rocks, iron formations and local evaporites, as well as rift-related (mainly mafic) magmatism (Billstrom et al., 2010). Subduction along the western margin resulted in a series of magmatic arcs and collisions between $\sim 1920 \mathrm{Ma}$ and $\sim 1750 \mathrm{Ma}$. Subduction-generated calcalkaline igneous rocks of the Porphyrite Group and Haparanda Suite granitoids and then alkaline igneous rocks of the Kiirunavaara Group and Perthite-Monzonite Suite, together with IOA and porphyry-style $\mathrm{Cu}-\mathrm{Au}$ deposits (Fig. S2, E1) were subjected to compressional tectonics during collision of a crustal block from the southwest (Fig. S2, event E2, and D3 of Lahtinen et al., 2018). A change in plate motion direction resulted in north-northwest-directed shortening and orocline development across northern Fennoscandia during the D4 event of Lahtinen et al. (2018), broadly coeval with metamorphism and the first major $\mathrm{Cu}-\mathrm{Au}-\mathrm{Fe}$ hydrothermal deposits such as Rakkurijarvi at $\sim 1864-1848$ Ma (Fig. S2, E3). This early Cu-Au-Fe hydrothermal activity, including regional $\mathrm{Na}-\mathrm{Ca}$ alteration, therefore appears to have occurred post-subduction in a synorogenic setting distal from the continental margin, perhaps associated with a switch in plate motion direction. Interestingly, Lahtinen et al. (2018) described some extensional domains within the Central Lapland region during their D4 event. The second major $\mathrm{Cu}-\mathrm{Au}-\mathrm{Fe}$ event (Fig. S2, E5, 1782-1757 Ma) also appears to have been syn-orogenic and distal from new arc magmatism along the continental margin well to the west, in a tectonic regime where shortening had switched back to an east-northeast direction (Lahtinen et al., 2018).

\section{Great Bear magmatic zone, Canada - Paleoproterozoic Au-Co-Bi, $\mathrm{Cu}$ and $\mathrm{U}$ deposits}

The Paleoproterozoic Great Bear magmatic zone (GBMZ) in northwestern Canada hosts well documented hydrothermal alteration and diverse types of mineralisation $\mathrm{C} C \mathrm{Cu}, \mathrm{Au}, \mathrm{U}, \mathrm{Co}, \mathrm{Mo}, \mathrm{V}$, etc) including small $\mathrm{Au}, \mathrm{Cu}$ and $\mathrm{U}$ resources that have been described within the context of 'iron oxide and alkali-altered systems' (Gandhi \& Bell, 1989; Corriveau, 2007; Mumin et al., 2007, 2010; Corriveau et al., 2010, 2016). Igneous rocks of the GBMZ are interpreted to have formed in a continental margin magmatic arc setting above an easterly-dipping subducting slab (Hildebrand et al., 1987; Ootes et al., 2017). Arc magmatism, initiated at $\sim 1876 \mathrm{Ma}$, was preceded by the shortlived Calderian orogeny which was caused by collision of an island arc (Hildebrand et al., 2010) or accretion of a previously rifted arc (Hottah terrane) with the western margin of the Slave Craton (Ootes et al., 2017). Rather than fully postdating the Calderian orogeny, as previously thought, early phases of the GBMZ magmatism ( 1876-1873 Ma) are now interpreted as syndeformational within a transpressional regime late within the Calderian orogeny, and exhibit 'syn-collisional' and 'volcanic arc' calc-alkaline geochemical signatures (Montreuil et al., 2016; Ootes et al., 2017). The later magmatic phases ( 1869-1866 Ma) show greater components of 'within-plate' and 'transitional' signatures and some units have shoshonitic compositions indicating a transition from collisional to a post-collisional and extensional setting (Montreuil et al., 2016; Ootes et al., 2017). The final stages of magmatism at $~ 1860-1850$ Ma comprise extensive and mainly A-type granites. Deformation style also transitioned from dominantly ductile and brittle-ductile up to 1871-1869 Ma to brittle deformation (Montreuil et al., 2016). Supracrustal rocks are areally subordinate to intrusive rocks in the GBMZ, and comprise small inliers of $\sim 1880$ Ma metasedimentary rocks of the Treasure Lake Group and older rocks of the Hottah terrane, together with somewhat larger areas of mainly andesitic and felsic volcanic rocks forming part of the 1876-1860 Ma Great Bear magmatism (see summaries by Slack et al., 2016; Ootes et al., 2017).

Iron oxide and alkali alteration such as sodic, sodic-calcic, Fe skarn and high-temperature Ca$\mathrm{Fe} \pm \mathrm{K}$ alteration commenced during the earlier stages of magmatism within a regime of ductile to brittle-ductile deformation (Corriveau et al., 2010; Montreuil et al., 2016). Syn- to predeformational Mo-Cu-U mineralisation associated with magnetite-K-feldspar \pm biotite alteration 
at the Nori prospect has yielded a molybdenite Re-Os age of $1877 \pm 8 \mathrm{Ma}$ (Acosta-Góngora et al., 2015; Montreuil et al., 2016), and deformed Mo-U-bearing veins with biotite, tourmaline and minor magnetite and chalcopyrite in the Southern Breccia Zone have a molybdenite Re-Os age of $1873 \pm 6 \mathrm{Ma}$ (Ootes et al., 2010). Magnetite-biotite-amphibole-K-feldspar alteration and Au-CoBi-As mineralisation at the NICO deposit (33 Mt @ $1.0 \mathrm{~g} / \mathrm{t} \mathrm{Au}, 0.11 \% \mathrm{Co}, 0.14 \%$ Bi, $0.04 \% \mathrm{Cu}$, Acosta-Góngora et al., 2015) appear to have formed during the waning stages of brittle-ductile deformation, inferred at $1870 \mathrm{Ma}$ (Acosta-Góngora et al., 2015; Montreuil et al., 2016) which is within error of an age of $1865 \pm 9$ Ma for deformed molybdenite interpreted to have formed during an early hydrothermal stage (Acosta-Góngora et al., 2015). A later retrograde stage with minor $\mathrm{Cu}, \mathrm{Bi}$, hematite and chlorite at NICO was related to brittle deformation-controlled IOCG style alteration-mineralisation, according to Montreuil et al. (2016). An undeformed $\sim 1868 \mathrm{Ma}$ dyke cuts the Au-Co-Bi ore zone and therefore sets a minimum age for such ore at NICO (AcostaGóngora et al., 2015) but not necessarily for the overprinting Cu-hematite-chlorite assemblage. Montreuil et al. (2016) further described IOCG and albitite-hosted U mineralisation associated with brittle deformation features such as brittle fractures and breccias, although no radiometric ages of such hydrothermal assemblages have been reported. An end to Na-Fe-Ca-K alteration and related hydrothermal activity by $\sim 1866 \mathrm{Ma}$ has been suggested, as unaltered plutons of this age cut the alteration. Similarly, Cu-U-V mineralisation at the FAB prospect associated with K-feldspar - amphibole - magnetite/hematite - biotite veins and breccias has been constrained to the period 1870-1867 Ma using zircon U-Pb ages of pre- and post-mineralisation intrusions (Montreuil et al., 2016). No radiometric age constraints are available for the small magnetite-hematite-fluoriterich breccia-hosted Sue Dianne Cu (-Au) deposit (resource of $8.4 \mathrm{Mt} @ 0.8$ \% Cu, $0.07 \mathrm{~g} / \mathrm{t} \mathrm{Au}$, Hennessey \& Puritch, 2008 reported in Corriveau et al., 2010).

Overall, the GBMZ transitioned from a late-orogenic phase of mainly intermediate-composition arc magmatism, brittle-ductile compressive deformation and early magnetite-rich K-Ca-Na alteration with relatively small $\mathrm{Au}-\mathrm{Co}-\mathrm{Bi}$ and $\mathrm{Mo} \pm \mathrm{U}$ deposits, to a later phase of post-orogenic $\mathrm{K}-$ rich arc-related magmatism, extensional and brittle deformation, and hematite-magnetite-rich $\mathrm{K}$ $\mathrm{Ca}-\mathrm{Na}$ alteration with currently known small resources of Fe-oxide-associated $\mathrm{Cu} \pm \mathrm{U}$ mineralisation. The timing of the later stage of $\mathrm{Cu}$ mineralisation has yet to be directly dated although it seems likely this was prior to $1865 \mathrm{Ma}$ (Montreuil et al., 2016).

Apatite-bearing magnetite-actinolite alteration and deposits of modest size also have been described in the GBMZ, and have been likened to Kiruna type IOA deposits (Hildebrand, 1986). They are recognised as forming the core parts of zoned hydrothermal IOAA systems with inner sodic and high-temperature $\mathrm{Ca}-\mathrm{Fe} \pm \mathrm{Mg}$ zones ( \pm skarn) grading outwards and upwards to hightemperature $\mathrm{K}-\mathrm{Fe}$, low-temperature $\mathrm{K}-\mathrm{Fe}-\mathrm{H}-\mathrm{CO}_{2}$ and finally $\mathrm{Si}$ zones in distal and/or shallow zones or alteration facies (Corriveau et al., 2010a, 2010b, 2016; Mumin et al., 2010). These systems along with associated $\mathrm{Au}, \mathrm{Co}, \mathrm{Bi}, \mathrm{Cu}$ and $\mathrm{U}$ mineralisation are interpreted to be spatially, temporally and genetically associated with GBMZ magmatism (Mumin et al., 2007, Corriveau et al., 2010a, 2010b, 2016; Acosta-Góngora et al., 2015; Montreuil et al., 2016; Ootes et al., 2017).

\section{Tennant Creek goldfield, Australia - Paleoproterozoic Au-Cu-Bi-Fe deposits}

High-grade $\mathrm{Au}-\mathrm{Cu}$-Bi deposits in the Tennant Creek goldfield are hosted by epigenetic magnetiteand/or hematite-rich bodies, locally known as ironstones, within a dominantly siliciclastic sedimentary Paleoproterozoic basin in the North Australian Craton. Of the $>500$ known ironstones only several dozen contain economic grades of $\mathrm{Au}$ and/or $\mathrm{Cu}$ and/or $\mathrm{Bi}$, the vast majority being barren of such metals (Wedekind et al., 1989). Ironstones appear to be confined to the Warramunga Formation, a sequence of low metamorphic grade turbiditic greywackes, siltstones and shales with distinctive yet volumetrically minor intervals of 'hematitic shales' and several felsic tuff units. The Warramunga Formation was deposited at $~ 1865-1860$ Ma (Fig. S3; Compston, 1995; Smith, 2001; Donnellan, 2013; Maidment et al., 2013). Disseminated magnetite 
is relatively abundant (up to several volume percent) in lower parts of the sequence, whereas the hematitic shales and most ironstones appear to be most common in upper parts of the Warramunga Formation. No carbonaceous units are known in the Tennant Creek goldfield, but minor carbonate-rich rock occurs within some hematitic shale intervals.

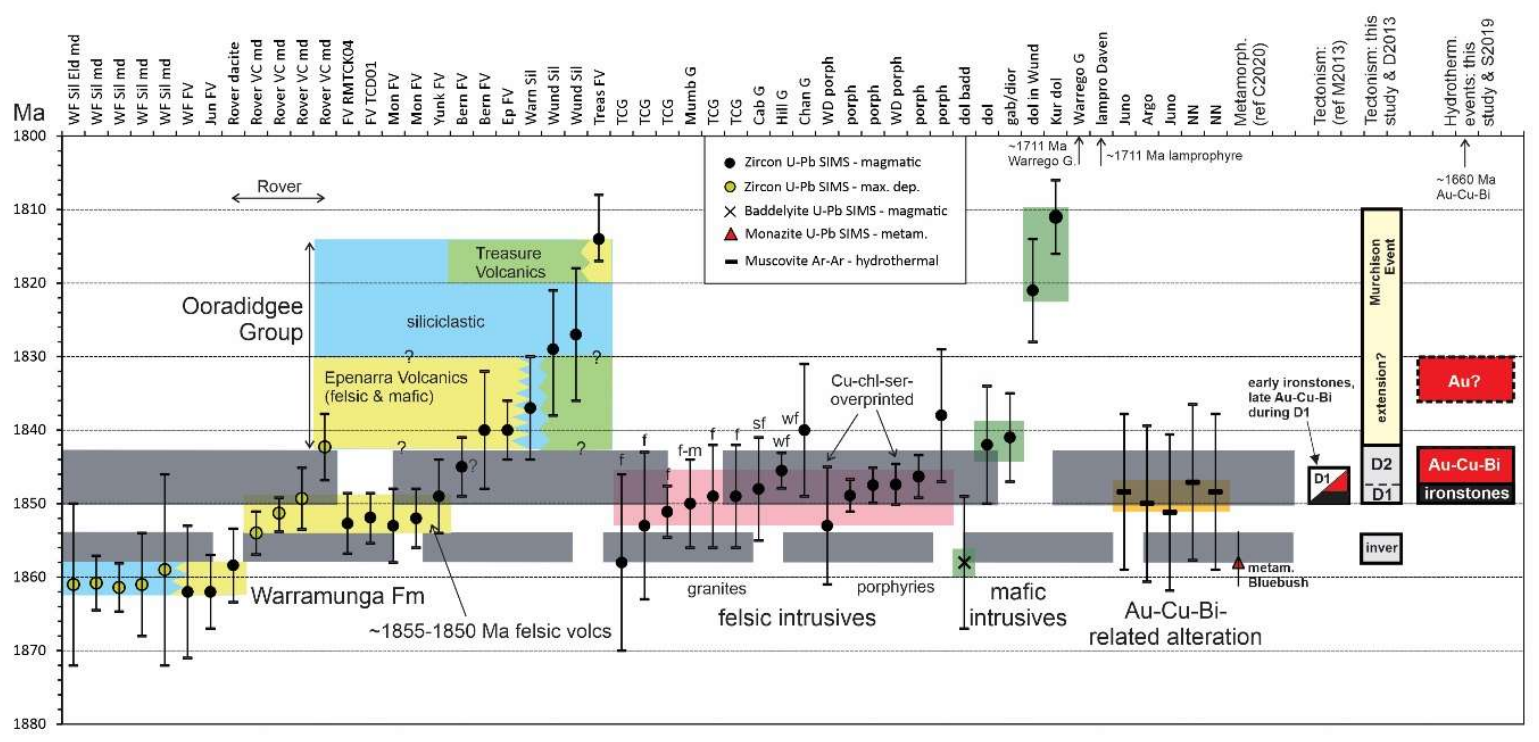

Figure S3. Synthesis of geochronology for mineralisation, tectonic, magmatic and supracrustal depositional events for the Tennant Creek goldfield and Rover field, northern Australia, from 1800 Ma to $1880 \mathrm{Ma}$. Abbreviations for granite samples: $\mathrm{f}$ - foliated, $\mathrm{f}-\mathrm{m}$ - foliated to massive, sf - strongly foliated, wf - weakly foliated; abbreviations for rock units: WF - Warramunga Formation, Jun - Junalki Formation, VC volcaniclastic, FV - felsic volcanic, Mon - Monument Formation, Bern - Bernborough Formation, Ep Epennara Volcanics, Warn - Warnbro Siltstone, Wund - Wundirgi Formation, Treas - Treasure Volcanics, Mumb G - Mumbilla Granite, TCG - Tennant Creek Granite, Cab G - Cabbage Gum Granite, Hill G - Hill of Leaders Granite, Chan G - Channingum Granite, WD porph - White Devil porphyry, dol - dolerite, gab/dior - gabbro/diorite, Kur dol - Kurinelli dolerite, lampro Daven - lamprophyre, Davenport region, NN - Nobles Nob deposit. References: Compston (1995), Smith (2001), Claoué-Long et al. (2008a, 2008b), Fraser et al. (2008), Donnellan (2013), Maidment et al. (2013), Skirrow et al. (2019), Cross et al. (2020), Huston et al. (2020).

The Warramunga Formation is intruded by widespread I-type granites and felsic porphyries of the Tennant Suite dated between 1854 Ma and 1846 Ma (Fig. S3; Compston, 1995; Smith, 2001; Donnellan et al., 1995; Donnellan, 2013; Maidment et al., 2013 ). This magmatism accompanied the D1 tectonothermal event, initially correlated with the Barramundi Orogeny of northern Australia (Compston, 1995) and then named the Tennant Event which was constrained by Maidment et al. (2013) to the period $\sim 1850-1845 \mathrm{Ma}$. The Ooradidgee Group, a sequence of bimodal felsic and mafic volcanic and siliciclastic sedimentary rocks, was emplaced unconformably upon older units including the Warramunga Formation (Fig. S3; Donnellan et al., 1995; Donnellan, 2013). The Ooradidgee Group includes the Epenarra Volcanics near its base and the Treasure Volcanics near its top (1840 $\pm 4 \mathrm{Ma}$, and $1814+3 /-6 \mathrm{Ma}$, respectively; Claoué-Long et al., 2008a). This sequence is overlain by siliciclastic and bimodal volcanic rocks of the layercake-like Hatches Creek Group, deposited from $1814 \pm 3$ Ma to 1800 Ma (Claoué-Long et al., 2008a). Constraining the timing of earliest Ooradidgee Group deposition has been problematic, yet it is important in understanding the tectonic and metallogenic evolution. Earlier studies placed several $\sim 1855-1850$ Ma felsic volcanic units (e.g. Monument Formation, Yunkulungu Formation) at the base of the Ooradidgee Group (Donnellan et al., 1995; Smith, 2001; Donnellan, 2013; Maidment et al., 2013). confirmed the presence of $~ 1855-1850$ Ma felsic volcanic units in several additional locations, peripheral to the exposed Tennant Creek inlier, and also included 
these units within the Ooradidgee Group. However, there are reasons to believe that the 1855 1850 Ma volcanic rocks may constitute a package that is stratigraphically separate from both the Ooradidgee Group and the Warramunga Formation, as discussed further below.

The latest major magmatic event in the Tennant Creek region includes S-type granites of the Devils Suite, with zircon U-Pb ages around 1710-1715 Ma (Wyborn et al., 1998; Donnellan, 2013). The Warrego Granite forms a large intrusion in the northwest part of the Tennant Creek province, and recently has been confirmed to be the same age as the Devils Suite $(1711 \pm 10 \mathrm{Ma}$, Huston et al., 2020). Finally, the timing of volumetrically minor lamprophyre dykes in the Tennant Creek region is best constrained by a U-Pb zircon age of $1711 \pm 3$ Ma (Claoué-Long et al., 2008b) indicating they may be broadly coeval with the Devils Suite magmatism.

The timing of deformation and metamorphic events has been only partly resolved in the Tennant Creek province. Deformation of the Warramunga Formation is characterised by tight, upright, folding and brittle-ductile shearing at low metamorphic grade (Rattenbury, 1994), and occurred during the regional D1 compressional Tennant Event (Wedekind et al., 1989; Compston, 1995; Donnellan et al., 1995; Donnellan, 2013; Maidment et al., 2013). This deformation also affected many of the Tennant Suite felsic intrusive rocks, with earlier intrusions exhibiting strong foliation and later phases tending to have weak or no tectonic foliation (Fig. S3). A second regional deformation event (D2, or D1a of Donnellan, 2013) also has been recognised which resulted in a locally well developed second tectonic foliation, brittle-ductile shearing, and other related deformation features (Nguyen et al., 1989; Skirrow, 1993, 2000; Donnellan et al., 1995; Skirrow \& Walshe, 2002; Donnellan, 2013). Broad open folding of the Hatches Creek Group and older units to the south of Tennant Creek represents the D3 regional deformation event (Donnellan, 2013), which also may have affected the Tennant Creek province.

Although the timing of metamorphism is not well constrained in the vicinity of the Au-Cu-Bi deposits, metamorphic monazite in deformed amphibolite facies rocks at the southwest margin of the Tennant Creek goldfield (Bluebush area) records a metamorphic age of 1858 Ma (Cross et al., 2020). This age appears at odds with the $\sim 1850-1845$ Ma timing of the D1 event proposed by Maidment et al. (2013). Also problematic is the overlapping ages of the earliest Ooradidgee Group volcanism, if this stratigraphic sequence commenced deposition at $\sim 1855-1850 \mathrm{Ma}$ as previously proposed, with the $\sim 1850-1845 \mathrm{Ma}$ age of D1 inferred by Maidment et al. (2013). It seems unlikely that such volcanism could have occurred at the same structural level in the same areas as D1 tight folding, brittle-ductile shearing, and low grade metamorphism. Furthermore, at least parts of the Ooradidgee Group have been affected only by open folding during D3, whereas the Warramunga Formation was tightly folded (e.g. Smith, 2001). Finally, the presence of minor ironstones within the 'Ooradidgee Group', and intrusion of Tennant Suite granites into lower parts of the 'Ooradidgee Group' (Smith, 2001), are difficult to explain if the Ooradidgee Group deposition commenced at $\sim 1855 \mathrm{Ma}$ and continued through the Tennant Event at $\sim 1850-1845$ Ma as previously proposed.

These relationships and inconsistencies may be reconciled in a revised event sequence as shown in Figure S3. This involves: (a) deposition of the $\sim 1855-1850$ Ma felsic volcanic rocks as a separate unit unconformably and/or disconformably upon the Warramunga Formation and prior to the $\sim 1840$ Ma Epenarra Volcanics of the Ooradidgee Group, (b) deposition of this volcanic unit during and/or after $\sim 1858$ Ma exhumation of the latter formation, which coincided with amphibolite facies metamorphism at depth at $1858 \mathrm{Ma}$ in the Bluebush area, and which also records the initial inversion of the Warramunga Formation, (c) continued deformation of the Warramunga Formation and $\sim 1855-1850$ Ma volcanic sequence within a fold and thrust belt (Rattenbury, 1992, 1994) during the low metamorphic grade Tennant Event at $\sim 1850-1845 \mathrm{Ma}$ in what has been termed the D1 deformation event, (d) a progressive rotation of stress axes resulting in the D1a event of Donnellan (2013) (termed the D2 deformation herein), (e) post-D2 deposition of the $\sim 1840-1814$ Ma Ooradidgee Group. There are implications of this revised model for the numbers of tectonic foliations in units of different age, which would provide a test 
of the proposed event sequence, and also for presence/absence of hydrothermal systems, as explained below.

Hydrothermal activity was closely linked to the regional tectonothermal evolution. Structural relationships indicate that the massive to banded magnetite-hematite-quartz-chlorite ironstones formed epigenetically during D1 tight folding, as generally steeply dipping lens-shaped and irregular bodies that cut stratigraphy at commonly high angles and occur within shear and fault zones with minor offsets (Wedekind et al., 1989; Rattenbury, 1992, 1994). Some ironstones have outer zones rich in Ca-Mg carbonates and/or talc (Wedekind et al., 1989). Whereas chloritic alteration with minor muscovite is ubiquitous, biotite alteration is uncommon (e.g. Navigator 6; West Peko), as are Fe silicates such as stilpnomelane, minnesotaite and greenalite (West Peko deposit; Skirrow, 1993, 2000; Skirrow \& Walshe, 2002).

The timing of $\mathrm{Au}-\mathrm{Cu}-\mathrm{Bi}$ mineralisation also has been problematic. Ore deposits in the goldfield range from $\mathrm{Cu}-\mathrm{Au}$-Bi-rich magnetite-pyrrhotite-pyrite styles to Au-Bi-rich magnetite- and/or hematite-rich styles (Wedekind et al., 1989; Huston et al., 1993; Skirrow, 2000; Skirrow \& Walshe, 2002). The vast bulk, if not all, of the sulfides and Au overprinted the magnetite \pm hematite-rich ironstones, and occur in syn-deformational brittle-ductile to brittle style veins, replacements and breccias cutting the ironstones and also occurring outside the ironstones in fault and shear zones (Wedekind et al., 1989; Huston et al., 1993; Skirrow, 2000; Skirrow \& Walshe, 2002; Cuison et al., 2014). Early dating studies of hydrothermal muscovite associated with Au mineralisation indicated an ${ }^{40} \mathrm{Ar}-{ }^{39} \mathrm{Ar}$ age of $\sim 1820-1830 \mathrm{Ma}$, interpreted as a minimum age of ore formation (Compston \& McDougall, 1994). This age, during the Ooradidgee Group volcanism, was apparently inconsistent with the syn-deformational timing of mineralisation and with known (earlier) tectonothermal and magmatic events (Fraser et al., 2008). Re-calibration of the ${ }^{40} \mathrm{Ar}-{ }^{39} \mathrm{Ar}$ ages based on revised decay constants and standards led Fraser et al. (2008) to revise the ${ }^{40} \mathrm{Ar}$ ${ }^{39} \mathrm{Ar}$ ages to $\sim 1850 \mathrm{Ma}$, in close alignment with the Tennant Event of Maidment et al. (2013), although the uncertainties are ca. \pm 10 million years (Fig. S3).

It has been previously proposed that the main $\mathrm{Au}-\mathrm{Cu}-\mathrm{Bi}$ mineralisation occurred during $\mathrm{D} 2$ (Nguyen et al., 1989; Skirrow, 1993; Skirrow \& Walshe, 2002) rather than during D1 as suggested by some other workers (e.g. Maidment et al., 2013). The absolute timing of the D2 event has not been determined directly. However, the $1847 \pm 3$ Ma age of a felsic porphyry intrusion at the White Devil deposit, which was overprinted by $\mathrm{Au}-\mathrm{Cu}$-Bi-related hydrothermal alteration, provides a maximum age of $\mathrm{Au}-\mathrm{Cu}-\mathrm{Bi}$ mineralisation at this site (Huston \& Cozens, 1994; Maidment et al., 2013). There are no robust isotopic minimum age constraints on $\mathrm{Au}-\mathrm{Cu}$-Bi ore formation other than the ${ }^{40} \mathrm{Ar}-{ }^{39} \mathrm{Ar}$ ages which have uncertainties ranging to as young as $\sim 1840$ 1836 Ma (Fig. S3; Fraser et al., 2008). Therefore, on balance, the most likely timing of the syn-D2 major Au-Cu-Bi mineralisation is inferred to have been between $\sim 1847 \mathrm{Ma}$ and $\sim 1842 \mathrm{Ma}$, prior to emplacement of the Ooradidgee Group but after at least some of the felsic porphyries. Although the suggested timing of $\mathrm{Au}-\mathrm{Cu}$-Bi overlaps with that proposed by Maidment et al. (2013) a synD2 rather than syn-D1 timing is suggested here, extending to as young as $\sim 1842 \mathrm{Ma}$.

Several lines of evidence suggest there was more than one base-precious metal mineralisation event in the Tennant Creek goldfield. First, $\mathrm{Pb}$ isotope data for Pb-rich minerals (mostly galena) indicates differences in composition between less radiogenic $\mathrm{Cu}$-rich $\mathrm{Au}$-Bi mineralisation in the Tennant Creek goldfield and more radiogenic $\mathrm{Cu}$ - and $\mathrm{Au}$-rich mineralisation (Huston et al., 2020). The difference may be explained either by a 10-15 m.y. age difference, and/or by different sources of lead (Huston et al., 2020). Conceivably, if the less radiogenic $\mathrm{Cu}-\mathrm{Au}-\mathrm{Bi}$ mineralisation formed at $\sim 1847-1843 \mathrm{Ma}$ as suggested above, then the more radiogenic $\mathrm{Cu}-$ and $\mathrm{Au}$-rich mineralisation could have formed as late as $\sim 1830 \mathrm{Ma}$ if its different isotopic composition is due to its younger age rather than a different $\mathrm{Pb}$ source (Fig. S3). A second, late-stage, Au event is also supported by the presence of texturally late high grade Au with hematite in breccias at the Eldorado deposit, representing a brittle deformation style that is rare in $\mathrm{Au}-\mathrm{Cu}$-Bi deposits of the Tennant Creek goldfield (Skirrow \& Walshe, 2002). Moreover, high grade Au mineralisation in 
'pods' at the Warrego deposit paragenetically overprints $\mathrm{Cu}-\mathrm{Au}-\mathrm{Bi}$ mineralisation (Wedekind et al., 1989).

An even later style of $\mathrm{Au}-\mathrm{Cu}$-Bi mineralisation in shear zones outside ironstones may have formed at $\sim 1660 \mathrm{Ma}$, possibly via re-distribution of earlier-formed mineralisation (Skirrow et al., 2019). This hydrothermal activity and other thermal events around the age of the Devils Suite magmatism ( $1710 \mathrm{Ma})$ may be the cause of the disturbance reported in K-Ar, Ar-Ar (e.g. Compston \& McDougall, 1994) and perhaps Re-Os isotopic data (e.g. McInnes et al., 2008).

Implications of these interpretations are (1) ironstones and syn-D2 Au-Cu-Bi mineralisation may not be restricted to the Warramunga Formation but also could exist within the $\sim 1855-1845 \mathrm{Ma}$ felsic volcanic sequence, (2) $\mathrm{Cu}$ and Au mineralisation with or without hematite hosted by brittle deformation features may be present within the older parts of the Ooradidgee Group and any older units.

In summary, Au-Cu-Bi mineralisation in the Tennant Creek province can be described as synorogenic as it formed syn-deformationally at initially brittle-ductile and low metamorphic grade conditions. Mineralisation post-dated the early stages of magmatism of the Tennant Suite and associated porphyries, and was coeval with the latest stages of this magmatism. Donnellan (2013) suggested that the D1 event was compressional whereas the D1a (equivalent to D2 herein) event may have been transpressional, in response to a rotation of stress fields. Given that the Ooradidgee Group contains bimodal volcanics, possibly indicating an extensional tectonic regime, we infer that $\mathrm{Cu}-\mathrm{Au}$-Bi mineralisation in the Tennant Creek goldfield formed during a switch from compressional (D1) to transpressional (D1a) tectonics prior to major regional extension (synOoradidgee Group). Further work is required to test the proposed revised temporal and tectonic framework.

\section{Gawler Craton and Curnamona Province - Mesoproterozoic Cu-Au-Fe (-U-REE) deposits}

\subsection{Overview of deposit types}

The Gawler Craton is a Mesoarchean to Mesoproterozoic crustal element in south-central Australia hosting the Olympic Dam Cu-U-Au deposit, the world's largest IOCG deposit and largest uranium resource $\left(10.73 \mathrm{Bt} @ 0.72 \% \mathrm{Cu}, 0.30 \mathrm{~g} / \mathrm{t} \mathrm{Au}, 0.23 \mathrm{~kg} / \mathrm{t} \mathrm{U}_{3} \mathrm{O}_{8}, 1.28 \mathrm{~g} / \mathrm{t} \mathrm{Ag}\right.$, measured + indicated + inferred resource, BHP, 2018, www.bhp.com). The Olympic $\mathrm{Cu}-\mathrm{Au}$ province forms a $>500 \mathrm{~km}$ length belt along the eastern margin of the Gawler Craton with major IOCG deposits in three districts that developed between $\sim 1600 \mathrm{Ma}$ and $1575 \mathrm{Ma}$ (Skirrow et al., 2002, 2007). In addition to Olympic Dam, this metallogenic province contains large $\mathrm{Cu}-\mathrm{Au}$ resources at the Prominent Hill deposit (160 Mt @ $1.0 \% \mathrm{Cu}, 0.7 \mathrm{~g} / \mathrm{t} \mathrm{Au}, 3 \mathrm{~g} / \mathrm{t} \mathrm{Ag}$, measured + indicated resources, OZ Minerals 2017, www.ozminerals.com) adjacent to the Mount Woods Inlier in the north, the Carrapateena and nearby Fremantle Doctor deposits (Carrapateena: $130 \mathrm{Mt} @ 1.5$ \% Cu, $0.6 \mathrm{~g} / \mathrm{t}$ $\mathrm{Au}, 7 \mathrm{~g} / \mathrm{t} \mathrm{Ag}$, measured + indicated + inferred resources, OZ Minerals 2017; Fremantle Doctor: inferred resource of $104 \mathrm{Mt} @ 0.7 \% \mathrm{Cu}, 0.5 \mathrm{~g} / \mathrm{t} \mathrm{Au}$ and $3 \mathrm{~g} / \mathrm{t} \mathrm{Ag}, \mathrm{OZ}$ Minerals 2018, www.ozminerals.com) in the Olympic Dam district, and the Hillside deposit (337 Mt @ $0.60 \% \mathrm{Cu}$, $0.14 \mathrm{~g} / \mathrm{t} \mathrm{Au}$, measured + indicated + inferred resources, Rex Minerals 2013, www.rexminerals.com.au) in the Moonta-Wallaroo district in the south. Many other smaller Cu$\mathrm{Au}$ deposits and prospects are known in the Olympic $\mathrm{Cu}-\mathrm{Au}$ province, with or without significant iron oxides, along with regional-scale hydrothermal alteration. Small quartz-vein style copper deposits and greisen-hosted Mo-bearing mineralisation in the Moonta district are examples without significant iron oxides (Conor et al., 2010). West of the Olympic $\mathrm{Cu}-\mathrm{Au}$ province, the Central Gawler gold province contains several small Au-only deposits characterised by quartz 
veinlet and disseminated mineralisation styles hosted by brittle-ductile shear zones (Ferris \& Schwarz, 2003; Budd \& Fraser, 2004; Budd \& Skirrow, 2007; Fraser et al., 2007). A number of epithermal style hydrothermal systems with local Ag and Pb-Zn enrichments and advanced argillic alteration have also been described in the south-central part of the Gawler Craton (Nicolson et al., 2017).

The Paleoproterozoic-Mesoproterozoic Curnamona Province lies $\sim 15-200 \mathrm{~km}$ to the east of the Gawler Craton, separated by Neoproterozoic to Cambrian rocks of the Adelaide Fold Belt. Although differing in much of its pre-1750 Ma geology, the Curnamona Province shares many features of the Gawler Craton after this time. In particular, the distinctive igneous rocks of the early Mesoproterozoic Hiltaba Suite and Gawler Range Volcanics (GRV) in the Gawler Craton have equivalents in the Curnamona Province (Jagodzinski \& Fricke, 2010; Schofield, 2010; Wade et al., 2012; Jagodzinski et al., 2016). The southwestern and central-western parts of the Curnamona Province, known as the Olary Domain, also contains several relatively small $\mathrm{Cu}$ - $\mathrm{Au}$ Mo deposits and hydrothermal alteration that resemble aspects of the early Mesoproterozoic hydrothermal $\mathrm{Cu}-\mathrm{Au}-\mathrm{Fe}$ systems in the Gawler Craton. For these reasons the geological and metallogenic evolution of both crustal elements are described sequentially in each sub-section, below (Fig. S4).

\subsection{Host rocks}

Iron oxide-rich to iron oxide-poor $\mathrm{Cu}-\mathrm{Au}$ deposits and related alteration in the Olympic $\mathrm{Cu}-\mathrm{Au}$ province of the Gawler Craton are hosted by $\sim 1850$ Ma to $\sim 1585$ Ma rocks including felsic and mafic intrusions of the 1850 Ma syn-orogenic Donington Suite (Hand et al., 2007; Reid, 2019), metasedimentary rocks of the $\sim 1760-1740$ Ma Wallaroo Group (Hand et al., 2007; Cowley, 2008), and felsic and mafic igneous rocks of the $\sim 1600$ Ma to $\sim 1580$ Hiltaba Suite and GRV. Although Meso- to Neoarchean rocks of generally medium-high grade metamorphic are widespread in basement to the west of the Olympic $\mathrm{Cu}$-Au province, Archean rocks are also known within the province, represented by the low metamorphic grade Devils Playground mafic volcanics between the Olympic Dam and Prominent Hill deposits (Reid et al., 2009). A key host rock for $\mathrm{Cu}-\mathrm{Au}-\mathrm{Fe}$ mineralisation in the metallogenic province is the volcano-sedimentary Wallaroo Group and equivalents (Hand et al., 2007) which is dominated by siltstone and fine-grained psammite, with lesser calcsilicates, quartzites, iron-rich sediments, graphitic schists and thinly bedded sodiumrich calc-albitite sediments locally rich in scapolite. The latter sodic lithologies are taken as evidence of former evaporitic minerals or rocks (Conor, 1995; Skirrow et al., 2007; Conor et al., 2010). The volcanic component is bimodal with A-type felsic units which, together with the evaporitic and Fe-rich nature of the sediments, has led to the suggestion of an extensional setting such as a rift along the eastern margin of the Gawler Craton (Hand et al., 2007; Conor et al., 2010). The timing of upper greenschist to lower amphibolite facies metamorphism, cleavage development, folding and shearing of the Wallaroo Group (Conor et al., 2010) has not been tightly constrained but this unit appears to have been unaffected by the medium to high grade metamorphism during the $\sim 1730-1690$ Ma Kimban orogeny that was prevalent in the Gawler Craton to the west of the Olympic Cu-Au province (Reid \& Fabris, 2015). More broadly, however, there is clear evidence of deformation associated with the $1595-1575$ Ma Hiltaba Suite in the Gawler Craton (Hand et al., 2007), as described further below. 


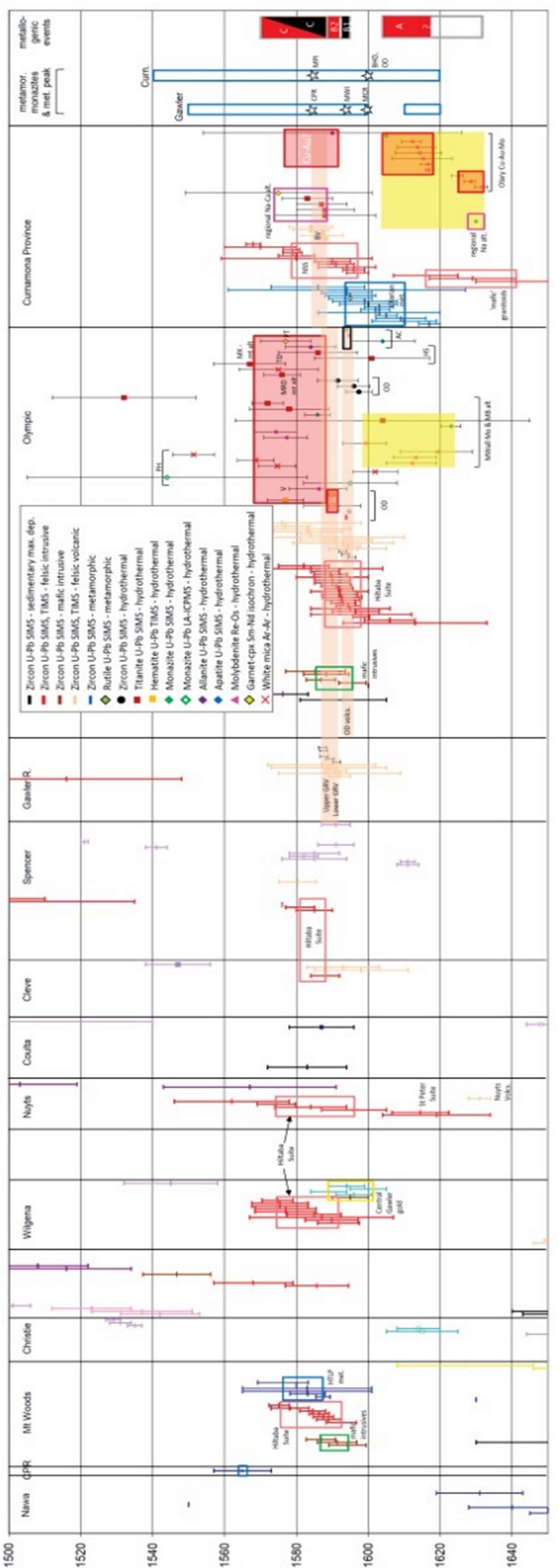

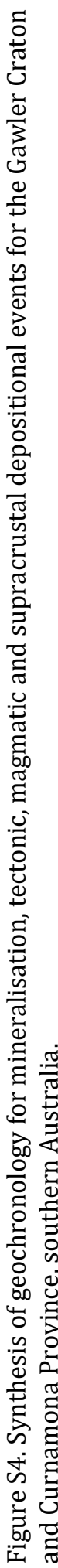


The 1730-1690 Ma Kimban orogeny and associated felsic intrusive magmatism in the Gawler Craton temporally overlaps with the ages of supracrustal rocks identified in the Curnamona Province, the Willyama Supergroup, where the oldest maximum depositional ages are $\sim 1730$ $1720 \mathrm{Ma}$ and the youngest are $\sim 1640 \mathrm{Ma}$ (Page et al., 2005; Conor \& Preiss, 2008). Extensive quartz-albite rocks in the lower parts of the Willyama Supergroup (Thackaringa Group in the Broken Hill Domain and Curnamona Group in the Olary Domain) are interpreted as sodic-altered psammopelitic sedimentary rocks associated with evaporitic environments (Cook \& Ashley, 1992). Minor iron formations are also present in the lower Willyama Supergroup. A-type felsic magmatism accompanied deposition of the Thackaringa and Curnamona groups which are unconformably overlain by the Upper Willyama Supergroup (Ashley et al., 1996; Fanning et al., 1998). This volcanic-sedimentary package is interpreted to have formed within a continental rift environment, with early crustal extension followed by sag-phase sedimentation (Willis et al., 1983; Conor \& Preiss, 2008).

\subsection{Metallogenic events in the Gawler Craton and Curnamona Province}

Metallogenic event A: Hydrothermal activity in the late Paleoproterozoic in the Gawler Craton commenced at $\sim 1620$ Ma with Mo-bearing and greisen style mineralisation in the MoontaWallaroo district of the southern Olympic $\mathrm{Cu}-\mathrm{Au}$ province (Fig. S4; Skirrow and Creaser, molybdenite Re-Os unpublished geochronological data). The timing of this early hydrothermal activity is supported by sparse dates from hydrothermal and/or metamorphic monazite and titanite in syn-deformational magnetite-biotite-albite and magnetite-amphibole-albite alteration of the Wallaroo Group, which record ages from $1623 \pm 3$ Ma to $1578 \pm 11$ Ma (Fig. S4; Conor, 1995; Raymond et al., 2002; Skirrow et al., 2002, 2007; Conor et al., 2010; Skirrow, 2010). Although magmatism of the $1633-1608$ Ma syn-tectonic and arc-related St Peter Suite (Swain et al., 2008; Reid et al., 2019) is known in the Gawler Craton only from far to the west of the Moonta-Wallaroo district, it temporally overlaps the period of metallogenic event A.

Metallogenic event $\mathrm{A}$ is also represented in the Curnamona Province. Several styles of $\mathrm{Cu}, \mathrm{Au}, \mathrm{Mo}$ and other mineralisation are known from the Olary Domain. Anomalous concentrations of $\mathrm{Cu}, \mathrm{Zn}$, $\mathrm{Pb}$, As and Co occur in stratabound zones within the calc-silicate- and pelite-pyrrhotite-bearing Bimba Formation, immediately above the unconformity between the lower and upper parts of the Willyama Supergroup. This style of mineralisation, which lacks significant Fe-oxides, has been likened to 'redbed' or stratiform sedimentary $\mathrm{Cu}(-\mathrm{Co})$ deposits such as those in the Zambian copper belt and the Kupferschiefer in Europe (Cook \& Ashley, 1992). Among the wide range of epigenetic sulfide deposits and occurrences in the Olary Domain (Bierlein et al., 1995) the White Dam $\mathrm{Au}$ (-Mo) deposit is distinctive in its lack of iron oxides, syn-deformational quartz-Kfeldspar-plagioclase-biotite vein style, high Au:Cu ratio, and lower stratigraphic position within medium grade metamorphic host rocks, compared to the main $\mathrm{Cu}-\mathrm{Au}$-Mo deposits (Williams \& Skirrow, 2000). Molybdenite has yielded Re-Os ages of $\sim 1631 \mathrm{Ma}, \sim 1616 \mathrm{Ma}$ and $1612 \mathrm{Ma}$ for the White Dam deposit (Fig. S4; Skirrow et al., 2000). In contrast, the Kalkaroo, North Portia and Waukaloo $\mathrm{Cu}-\mathrm{Au}-\mathrm{Mo}$ deposits to the north of White Dam are hosted by lower metamorphic grade (upper greenschist facies) mainly albite \pm magnetite-rich metasedimentary rocks, and exhibit evidence of both stratabound (Armistead et al., 2018) and transgressive vein and related replacement styles (Skirrow et al., 2000; Teale \& Fanning, 2000; Williams \& Skirrow, 2000). Although magnetite is common in bedding-transgressive quartz \pm K-feldspar \pm amphibole \pm biotite veins with $\mathrm{Cu}-\mathrm{Au}-\mathrm{Mo}$ mineralisation much of the $\mathrm{Cu}-\mathrm{Au}-\mathrm{Mo}$ mineralisation occurs in stratabound replacements and discordant veins with little or no iron oxides (Williams and Skirrow, 2000; Teale and Fanning, 2000). Such mineralisation is therefore not strictly of IOCG style but can be likened to ISCG deposits and is broadly associated with magnetite-rich $\mathrm{Cu}-\mathrm{Au}-\mathrm{Mo}$ mineralisation in other parts of the same deposits (e.g. Kalkaroo). Dating of molybdenite has yielded ages of $\sim 1628-1625 \mathrm{Ma}$ at Kalkaroo and $\sim 1615-1613 \mathrm{Ma}$ at North Portia and Waukaloo (Fig. S4; Skirrow et al., 2000; Skirrow \& Suzuki, unpublished data). Re-analysis of a Waukaloo 
sample returned a molybdenite Re-Os age of $\sim 1605$ Ma (Skirrow and Creaser, upublished data), in good agreement with the U-Pb SIMS age of 1605 Ma for hydrothermal monazite associated with $\mathrm{Cu}-\mathrm{Au}-\mathrm{Mo}$ mineralisation at the North Portia deposit (Teale \& Fanning, 2000).

Regionally extensive and stratabound sodic alteration in the Curnamona Province has been constrained by few isotope dates, the oldest of which is $\sim 1630 \mathrm{Ma}$ for monazite associated with albitisation near the North Portia Cu-Au-Mo deposit (Teale \& Fanning, 2000). However, it is possible that some regional sodic alteration occurred much earlier, during and/or soon after deposition of the host sequences in the rift basin.

Accordingly, we suggest that earliest Mo $( \pm \mathrm{Au})$ mineralisation may have commenced at $\sim 1630$ $1620 \mathrm{Ma}$, with a possibly main period of $\mathrm{Cu}-\mathrm{Au}$-Mo mineralisation at $\sim 1610-1605 \mathrm{Ma}$ in the Curnamona Province. The earlier part of this broad metallogenic event A (Fig. S4) may predate the peak of the Olarian Orogeny at $\sim 1600 \mathrm{Ma}$ as recorded by U-Pb ages of metamorphic zircon overgrowths and monazite (Page et al., 2005; Forbes et al., 2007), and therefore could represent pre-orogenic mineralisation (Armistead et al., 2018). However, the later and arguably most important $\mathrm{Cu}-\mathrm{Au}$ mineralisation within metallogenic event $\mathrm{A}$ at $\sim 1605 \mathrm{Ma}$ in the Curnamona Province appears to temporally overlap with the earliest stages of the Olarian Orogeny, and hence can be considered early-orogenic. Whether this phase of mineralisation represents remobilisation of earlier-formed mineralisation during deformation (Armistead et al., 2018) or a separate syn-deformational $\mathrm{Cu}-\mathrm{Au}-\mathrm{Fe}(-\mathrm{Mo})$ mineralising event, as preferred herein, remains to be confirmed. The timing of $\mathrm{Cu}-\mathrm{Au}$-Mo mineralisation also overlaps (within uncertainties) with the ages of several I-type granitoid intrusions dated at $1641 \pm 11 \mathrm{Ma}$ to $1616 \pm 9 \mathrm{Ma}$ in the Olary Domain (Cook et al., 1994; Ashley et al., 1997; Fanning et al., 1998), but the spatial and genetic relationships between the $\mathrm{Cu}-\mathrm{Au}-\mathrm{Mo}$ and the intrusions remain unclear.

In conclusion, it is tentatively proposed that the $\sim 1630-1605$ Ma metallogenic event A affected both the Curnamona Province and parts of the southeastern Gawler Craton, and resulted in preto early-orogenic $\mathrm{Mo}( \pm \mathrm{Au})$ and $\mathrm{Cu}-\mathrm{Au}-\mathrm{Fe}(\mathrm{Mo})$ mineralisation.

Metallogenic events B and C (Fig. S4): The major period of $\mathrm{Cu}-\mathrm{Au}-\mathrm{Fe}$ mineralisation in the Gawler Craton occurred during 1600-1575 (Fig. S4, right side, events B and C), broadly coeval with granitic and mafic intrusions of the Hiltaba Suite and the mafic to felsic Gawler Range Volcanics. Earliest phases of the high-temperature A- and I-type Hiltaba Suite granitoids at 1600-1595 Ma were syntectonic (Daly et al., 1998; Ferris et al., 2002; Budd, 2006; Hand et al., 2007; Conor et al., 2010), and some of the earlier GRV units are folded (e.g. Daly et al., 1998). Although later intrusive phases and younger GRV units are generally undeformed there is geochronological evidence of deformation and metamorphism along several major shear/fault zones in the southern and central Gawler Craton between $\sim 1611$ Ma and $\sim 1580$ Ma (Hand et al., 2007). Similar to the temporally overlapping Olarian Orogeny in the Curnamona Province, this tectonothermal activity was interpreted by Hand et al. (2007) to have occurred in an overall compressive regime, with northwest-southeast shortening. However, at least local and transient extensional conditions also appear to have existed when much of the GRV and equivalents in the Curnamona Province with associated sedimentary rocks were deposited, as implied in many earlier models of an intracontinental tectonic setting during the Hiltaba-GRV event (e.g. Daly et al., 1998; Giles, 1988). As noted by Skirrow (2010) extension is supported by the geochemistry of compositionally bimodal mafic to felsic magmatism, seismic reflection data showing GRV-filled half-graben (Carr et al., 2010), and sedimentary basinal deposition coeval with the GRV (Curtis et al., 2018). Recent high-precision U-Pb zircon dating by TIMS has revealed that GRV felsic volcanic rocks were deposited in two discrete stages: at 1595-1593 Ma in the Olympic Dam district, and at 1591$1587 \mathrm{Ma}$ in the central Gawler Craton (lower and upper GRV) and northwestern Curnamona Province (Jagodzinski et al., 2016; McPhie et al., 2020). 
Importantly, magnetite-rich veins with local pyrite and apatite but lacking significant copper mineralisation at the Acropolis prospect are inferred to have formed at $\sim 1594 \mathrm{Ma}$, with a maximum age constrained by the early felsic volcanism (1594.03 $\pm 0.68 \mathrm{Ma})$ and a minimum age constrained by the age of felsic dykes that lack magnetite veins, with an age of $1593.88 \pm 0.56 \mathrm{Ma}$ (McPhie et al., 2020). The ages of Hiltaba Suite granite host rocks at both Olympic Dam and Acropolis (1593.87 $\pm 0.21 \mathrm{Ma}$ and $1594.88 \pm 0.50$; Cherry et al., 2018; McPhie et al., 2020) are very similar and provide maximum ages of $\mathrm{Cu}-\mathrm{U}-\mathrm{Au}$ mineralisation at these locations. An age of $\sim 1590 \mathrm{Ma}$ was determined for $\mathrm{Cu}-\mathrm{U}-\mathrm{Au}$ mineralisation at the Olympic Dam deposit by Johnson \& Cross (1995); this timing has been confirmed and refined by dating of hydrothermal hematite associated with $\mathrm{Cu}-\mathrm{U}-\mathrm{Au}$, with ages of $1590 \pm 8 \mathrm{Ma}\left({ }^{207} \mathrm{~Pb}-206 \mathrm{~Pb}\right.$ LA-ICPMS age, Ciobanu et al., $2013)$ and more precisely at $1589.91 \pm 0.91 \mathrm{Ma}\left({ }^{207} \mathrm{~Pb}-206 \mathrm{~Pb}\right.$ TIMS age, Courtney-Davies et al., 2019). A zircon age of $1590.97 \pm 0.58 \mathrm{Ma}$ from blocks of altered bedded volcaniclastic rocks in the mineralised Olympic Dam Breccia Complex (Cherry et al., 2018) provides a further maximum age constraint on the timing of hydrothermal activity at Olympic Dam. Therefore, the highprecision dating permits the conclusion that the magnetite-apatite veining at $\sim 1594 \mathrm{Ma}$ at Acropolis occurred about 4 million years prior to the main $\mathrm{Cu}-\mathrm{U}$-Au ore-forming event at Olympic Dam.

Younger ages recorded in hematite at Olympic Dam (1577 $\pm 5 \mathrm{Ma}$, Ciobanu et al., 2013), and in hydrothermal molybdenite, titanite, monazite, apatite and white mica through to $1570 \mathrm{Ma}$ in the Olympic $\mathrm{Cu}-\mathrm{Au}$ province indicate that $\mathrm{Cu}-\mathrm{Au}-\mathrm{Fe}$ hydrothermal activity continued over a period of at least 20-25 m.y., possibly in several stages (Fig. S4, event C; Skirrow et al., 2007; Conor et al., 2010; Gregory et al., 2011; Reid et al., 2013; Bowden et al., 2017; Cherry et al., 2018). Several later (hydro)thermal events of relatively minor significance in terms of metal accumulation subsequently affected the eastern Gawler Craton and caused resetting of ages and/or remobilisation of various minerals (e.g. Davidson et al., 2007; Conor et al., 2010; Cherry et al., 2018). The Kararan orogeny ( 1570-1550 Ma, Hand et al., 2007) is characterised by medium-high grade metamorphism and is apparently confined to the northern Gawler Craton (e.g. Mt Woods Inlier, Mabel Creek Ridge, Coober Pedy Ridge; Fig. S4; Hand et al., 2007). Although all of the known major $\mathrm{Cu}-\mathrm{Au}$-Fe deposits occur to the south of these Kararan medium-high grade terranes, the Mt Woods Inlier contains several small magnetite-rich deposits with low grade $\mathrm{Cu}$ (e.g. Cairn Hill, Freeman \& Tomkinson, 2010). Their affinity to Kiruna type IOA or to $\mathrm{Cu}-\mathrm{Au}-\mathrm{Fe}$ deposits is unclear.

In the Curnamona Province, there are no reported radiometric ages for $\mathrm{Cu}-\mathrm{Au}$ mineralisation during metallogenic events $\mathrm{B}$ and $\mathrm{C}$. However, the timing of syn-deformational (syn-D3), transgressive and in-part shear-related sodic and sodic-calcic alteration has been constrained to 1588-1583 Ma by U-Pb SIMS dating of hydrothermal titanite (Fig. S4; Skirrow et al., 2000; Skirrow and Fletcher, unpublished data). There is also evidence for base metal leaching and redistribution within the widespread $\mathrm{Na}$ and $\mathrm{Na}-\mathrm{Ca}$ alteration zones (e.g. Clark et al., 2005; Skirrow \& Ashley, unpublished data).

\subsection{Summary and tectonic settings - Gawler Craton and Curnamona Province}

In summary, small deposits of epigenetic $\mathrm{Cu}$, Mo and $\mathrm{Au} \pm$ magnetite formed at $\sim 1630-1605 \mathrm{Ma}$ prior to and during the early stages of the Olarian orogeny, a compressional event that inverted 1760-1640 Ma rift basins in both the Gawler Craton and Curnamona Province and resulted in a metamorphic peak at $\sim 1600$ Ma in the latter region (Page et al., 2005; Forbes et al., 2007). Syndeformational Na-Ca and Fe-K-Ca-Na magnetite-biotite-bearing alteration commenced in the Moonta-Wallaroo and possibly in the Mt Woods Inlier late within the Olarian orogeny as bimodal magmatism flared up. Mineralogically and structurally distinct from these biotite-albite-bearing assemblages, apatite-bearing magnetite-K-feldspar-actinolite-carbonate \pm pyrite veins in the Olympic Dam district formed during brittle deformation at 1594 Ma. Crucially, precise dating 
has shown that this essentially Cu-barren magnetite-apatite-bearing alteration predated the formation of the principal $\mathrm{Cu}-\mathrm{U}-\mathrm{Au}$ mineralisation at Olympic Dam by $\sim 4$ m.y., whereas $\mathrm{Cu}-\mathrm{Au}$ mineralisation at the Prominent Hill and Hillside deposits may have formed up to $\sim 20$ m.y. later than the initial magnetite-apatite alteration. Overall, the major $\mathrm{Cu}-\mathrm{Au}-\mathrm{Fe}$ ore-forming systems in the Gawler Craton are considered to have formed in a broadly late-orogenic to post-orogenic tectonic setting, during a switch from compressional to extensional tectonism.

Various geodynamic scenarios have been proposed for the Gawler Craton and Curnamona Province during the early Mesoproterozoic, with earlier models emphasising intracontinental 'anorogenic' settings (e.g. Daly et al., 1998; Giles, 1988) which were incorporated into some models of global IOCG deposits (e.g. Hitzman, 2000; Groves et al., 2010). However, the recognition of syn-orogenic as well as cryptic subduction-related features in the late Paleoproterozoic to early Mesoproterozoic geology of the region (e.g. Hand et al., 2007) has led to several alternative geodynamic proposals. Most place the Olympic $\mathrm{Cu}-\mathrm{Au}$ province in an upper plate distal from subduction at a continental margin, and account for the Olarian orogeny via arc/continent collision or oceanic plateau subduction. However, there is debate on the geodynamic mechanisms of heating that produced the Hiltaba Suite, GRV and temporally associated $\mathrm{Cu}-\mathrm{Au}-\mathrm{Fe}$ mineralisation (e.g. Ferris et al., 2002; Betts et al., 2009; Skirrow et al., 2018; Tiddy \& Giles, 2020).

\section{Cloncurry province, Australia - Mesoproterozoic $\mathrm{Cu}-\mathrm{Au}-\mathrm{Fe}$ deposits}

The Cloncurry district of the eastern Mt Isa Inlier, Queensland, hosts numerous Mesoproterozoic $\mathrm{Cu}-\mathrm{Au}-\mathrm{Fe}$ deposits of diverse character including large magnetite-rich $\mathrm{Cu}-\mathrm{Au}$ deposits such as Ernest Henry (grade, tonnage) and Mt Elliott, pyrrhotite- and/or pyrite-rich Cu-Au deposits with variable amounts of magnetite (e.g. Eloise, Osborne), and hematite-rich deposits with high $\mathrm{Au}: \mathrm{Cu}$ ratios (e.g. Starra; Williams, 1998; Haynes, 2000; Williams et al., 2005). Most of the iron oxiderich $\mathrm{Cu}-\mathrm{Au}$ deposits have been described as IOCG deposits (Williams et al., 2005) whereas the iron oxide-poor members, or iron sulfide $\mathrm{Cu}$-Au (ISCG) deposits, have been considered to be variants of IOCG deposits (Haynes, 2000). The giant Mt Isa Cu deposit, which lacks significant Fe oxides and $\mathrm{Au}$, was also included in the latter group by Haynes (2000). The Cloncurry district also hosts the giant Paleoproterozoic Cannington Ag-Pb-Zn deposit (Walters \& Bailey, 1998) and the high-grade Mo-Re but Fe-oxide- and Cu-Au-poor Merlin deposit (Babo et al., 2017).

Copper-Au-Fe deposits of the Cloncurry district are hosted by metamorphosed sedimentary, volcanic and intrusive rocks that form parts of three superbasins deposited as rift-sag sequences between $\sim 1790 \mathrm{Ma}$ and $\sim 1575 \mathrm{Ma}$ across the Mt Isa Inlier (Blake, 1987; Southgate et al., 2000, 2013). Back-arc, intracontinental, and/or extended continental (passive) margin depositional settings have been proposed for the superbasins (e.g. Scott et al., 2000; Southgate et al., 2000, 2013; Giles et al., 2002; Gibson et al., 2016 ). In the Cloncurry District (part of the Eastern Succession of the Mt Isa Inlier) the lower sequences comprise bimodal volcanic rocks and overlying siliciclastic and calcareous sedimentary rocks (now calcsilicate- and scapolite-bearing, including the Corella Formation and Doherty Formation) of the Leichardt Superbasin, and upper sequences of siliciclastic, carbonaceous pelitic and mafic volcanic rocks (e.g. Soldiers Cap Group, Young Australia Group) which are part of the Isa Supergroup (Blake, 1987; Scott et al., 2000; Foster \& Austin, 2008; Southgate et al., 2013). In broad terms the lower sequence is relatively oxidised, as it contains sulfate-bearing scapolite (Morrissey \& Tomkins, 2020) and lacks abundant carbonaceous units, whereas the upper sequence is relatively reduced as indicated by the presence of carbonaceous units (e.g. Answer Slate, Marrimo Slate) and mafic volcanics (e.g. Toole Creek Formation) and lack of ex-evaporitic rocks. The youngest units in the Cloncurry district were deposited at or after $\sim 1618-1610$ Ma (Tommy Creek Formation and upper Marimo Slate, Foster \& Austin, 2008). Extensive Fe-rich tholeiitic dolerite/gabbro/trondhjemite dykes and sills 
were emplaced within the Soldiers Cap Group and elsewhere in the Eastern Succession, and are believed to be related to the voluminous mafic Toole Creek Volcanics $(1658 \pm 8$ Ma; Foster \& Austin, 2008; Oliver et al., 2008) and/or earlier events (e.g. $1686 \pm 6$ Ma sills, Rubenach et al., 2008). An early stage of localised sodic (albitic) alteration and $\mathrm{Cu}-\mathrm{Au}$ leaching from the mafic rocks and local re-precipitation may have occurred in association with these mafic intrusions (Oliver et al., 2008; Rubenach et al., 2008). The three basin supersequences and related felsic and mafic intrusions were subjected to the first phase of the compressional Isan Orogeny at 1595$1580 \mathrm{Ma}$, when peak metamorphic conditions in the amphibolite facies were attained in the Cloncurry district (syn-D2; Foster and Austin, 2008; Foster \& Austin, 2008; Tiddy \& Giles, 2020). The earliest stages of this heating event may have commenced by 1640 Ma (Oliver et al., 2008; Rubenach et al., 2008). Whereas only minor magmatism (e.g. pegmatites and mafic dykes, Oliver et al., 2008) accompanied this first phase of the Isan Orogeny there is field evidence for syn-D2 regional-scale sodic alteration and locally associated K-Fe (e.g. biotite) alteration (Rubenach \& Lewthwaite, 2002). Titanite associated with albite, magnetite and biotite alteration at the Starra deposit records a U-Pb age of $\sim 1595 \mathrm{Ma}$, described by Duncan et al. (2011) as representing Na$\mathrm{Ca}$ alteration but perhaps also recording the timing of magnetite-biotite-albite (Fe-K-Na) alteration. Iron leaching and redeposition during this and/or later deformational events may have produced some of the large 'ironstones' in the Cloncurry district (Williams, 1994).

The earliest major $\mathrm{Cu}-\mathrm{Au}-\mathrm{Fe}$ deposits in the Cloncurry district formed during this first phase of the Isan Orogeny, as recorded by molybdenite Re-Os, titanite U-Pb and amphibole ${ }^{40} \mathrm{Ar}-{ }^{39} \mathrm{Ar}$ ages at the Osborne $\mathrm{Cu}-\mathrm{Au}$ deposit ( 1600-1595 Ma; Perkins \& Wyborn, 1998; Gauthier et al., 2001; Duncan et al., 2011). Oliver et al. (2008) proposed that some $\mathrm{Fe} \pm \mathrm{Cu}$ sulfides and magnetite in banded rocks at the Osborne, Eloise, and Starra deposits may have formed prior to the D2 metamorphic peak of the early Isan Orogeny, consistent with the $\sim 1600-1595$ Ma ages for hydrothermal minerals at Osborne. Some $\mathrm{Fe}$ and $\mathrm{Cu}$ were then redistributed during the early phase of the Isan Orogeny (Oliver et al., 2008). A Re-Os age of 1567 Ma for molybdenite associated with $\mathrm{Cu}-\mathrm{Au}$ mineralisation at the Starra deposit may indicate introduction of $\mathrm{Cu}-\mathrm{Au}$ Mo during post-peak stages of the early phase of the Isan Orogeny (Duncan et al., 2011).

The second, post-peak-metamorphic, phase of the Isan Orogeny occurred between $\sim 1550 \mathrm{Ma}$ and $\sim 1500 \mathrm{Ma}$, during which several deformation stages have been identified (e.g. D3 shortening at $\sim 1550 \mathrm{Ma}$, D4 transpression at $\sim 1530 \mathrm{Ma}$, Rubenach et al., 2008; D5 extension at $\leq 1500 \mathrm{Ma}$, Austin \& Blenkinsop, 2010). Felsic intrusions of the Williams and Naraku batholiths were initially emplaced at $\sim 1550 \mathrm{Ma}$ early in this second phase of the Isan Orogeny, with large volumes intruded during $\sim 1530-1500 \mathrm{Ma}$ and continuing to $\sim 1490 \mathrm{Ma}$ (see geochronology summary in Duncan et al., 2011 and references therein). Compositions range from early tonalite-trondhjemite ( $1550 \mathrm{Ma})$ to later K-rich A-type monzodiorite, monzonite and monzogranite (Mark, 2001), with evidence of mixing/mingling between felsic and mafic magmas (Rubenach et al., 2008). Renewed and widespread $\mathrm{Na}$ (-Ca) alteration occurred along major fault/shear zone corridors at $\sim 1550-1520 \mathrm{Ma}$, based on sparse titanite U-Pb dates; at least some Na-Ca alteration also was spatially and temporally associated with Williams-Naraku plutons (Mark et al., 2004; Oliver et al., 2004). Several large magnetite bodies also formed within or in close proximity to felsic intrusions of the Williams-Naraku batholiths, such as the magnetite-feldspar-quartz accumulations within the Lightning Creek sill complex (Perring et al., 2000).

Many of the major $\mathrm{Cu}-\mathrm{Au}-\mathrm{Fe}$ deposits in the Cloncurry district record hydrothermal mineral ages between $\sim 1530 \mathrm{Ma}$ and $\sim 1500 \mathrm{Ma}$ (e.g. molybdenite Re-Os, titanite U-Pb, amphibole and biotite Ar-Ar ages; Perkins \& Wyborn, 1998; Gauthier et al., 2001; Duncan et al., 2011). This timing overlaps with the felsic (-mafic) magmatism of the Williams-Naraku batholiths as well as with regional $\mathrm{Na}-\mathrm{Ca}$ alteration and the D3 deformation event within the later phase of the Isan Orogeny. Consistent with a syn-deformational and syn- or late-orogenic timing, many of the 1530-1500 Ma Cu-Au-Fe deposits are hosted by structures such as brittle-ductile shear zones and faults (e.g. Ernest Henry - Mark et al., 2006; Starra - Rotherham, 1997; Eloise - Baker \& Laing, 
1998; Mt Elliott - Brown \& Porter, 2010). The unusual Merlin Mo-Re deposit, which lacks iron oxides and has low $\mathrm{Cu}$ and $\mathrm{Au}$ contents, formed over several stages commencing at $1535 \mathrm{Ma}$ and with later stages at $1520 \mathrm{Ma}$ and $\sim 1500 \mathrm{Ma}$ (Duncan et al., 2011; Babo et al., 2017). Significantly, many of the $\mathrm{Cu}-\mathrm{Au}-\mathrm{Fe}$ deposits with reduced assemblages (e.g. pyrrhotite-pyrite-biotite-rich), with or without magnetite (e.g. Osborne, Eloise, Greenmount), are hosted by the upper, relatively reduced, metasedimentary-metavolcanic rock package (e.g. Soldiers Cap Group, Young Australia Group). Conversely, deposits containing relatively oxidised hydrothermal assemblages (e.g. lacking pyrrhotite but containing magnetite, hematite, K-feldspar and/or sulfates) appear to be mostly hosted by rocks of the lower sequence which is of broadly intermediate to oxidised redox character (e.g. Ernest Henry, E1), or occur close to the contact between the upper and lower sequences (e.g. Monakoff, Starra). The Mt Elliott-SWAN deposit straddles this boundary and exhibits a broad zoning from anhydrite-magnetite-pyrite-bearing assemblages in the SWAN deposit (hosted by the Stavely Formation) to more reduced pyrrhotite-magnetite-bearing assemblages in the Mt Elliott deposit hosted by the upper sequence (Brown \& Porter, 2010). The issue of local-scale host rock control on such mineralogy (e.g. (Haynes, 2000)) versus broader scale controls on fluid composition are discussed in the accompanying contribution (Skirrow, in prep.).

In summary, both of the two main stages of $\mathrm{Cu}-\mathrm{Au}-\mathrm{Fe}$ mineralisation in the Cloncurry district were broadly syn-orogenic, with the earlier stages coeval with the first phase of the Isan Orogeny (with early-, syn- and late-orogenic timing), and the second during the syn-D4 to syn-D5 events of the later phase of the Isan Orogeny. Interestingly, this latter and major $\mathrm{Cu}-\mathrm{Au}-\mathrm{Fe}$ event along with separate and rare high-grade Mo-Re mineralisation appear to have occurred across a period when tectonism switched from compression (D3) to transpression (D4) to at least local extension (D5; Austin \& Blenkinsop, 2010). The two phases of the Isan Orogeny have been attributed to plate convergence and terrane accretion distal from the Mt Isa Inlier, initially to the south commencing at $\sim 1640 \mathrm{Ma}$ and then to the east (Scott et al., 2000; Southgate et al., 2000, 2013; Giles et al., 2002; Gibson et al., 2016).

\section{Kangdian province (China )and Sin Quyen Cu-Au deposit (Vietnam) - Paleo- to Neoproterozoic $\mathrm{Cu}-\mathrm{Au}$ and Fe deposits}

The $\sim 300 \mathrm{~km}$ long Kangdian metallogenic province in the southwestern Yangtze block of China contains several large $\mathrm{Cu}-\mathrm{Au}$ deposits associated with iron oxides as well as separate Fe-oxide and stratabound $\mathrm{Cu}$ deposits known locally as stratiform sedimentary copper or SSC deposits (e.g. Zhao \& Zhou, 2011; Zhou et al., 2014; Zhu et al., 2019; Lin et al., 2020 Zhao and Zhou, 2011; Zhou et al., 2014; Zhu et el., 2019; Lin et al., 2020). The province is important not only economically but also on account of the range of $\mathrm{Cu}$ and $\mathrm{Fe}$ deposits, the presence of gabbro/dolerite intrusions near the $\mathrm{Cu}-\mathrm{Au}-\mathrm{Fe}$ deposits, carbonate-rich basinal host rocks, and apparent absence or presence of only minor felsic intrusive rocks in the $\mathrm{Cu}-\mathrm{Au}-\mathrm{Fe}$ districts. Although the stratigraphy is relatively well understood, constraining the timing of deformation, metamorphic and mineralisation events has proved problematic in the Kangdian $\mathrm{Cu}$ province, probably due to multiple overprinting events. The major $\mathrm{Cu}$ and Fe deposits are hosted by Paleoproterozoic supracrustal rocks with maximum ages of $\sim 1742-1681 \mathrm{Ma}$ and which comprise metamorphosed siliciclastic rocks (mica schists, meta-conglomerate), meta-carbonates, amphibolite, and minor carbonaceous schist and felsic meta-volcanic rocks which were extensively albitised (Zhao \& Zhou, 2011; Zhou et al., 2014). Zircon dating of gabbro and dolerite bodies within a few kilometres of the Fe and $\mathrm{Cu}$ deposits indicate intrusive ages mostly in the range $\sim 1720-1659$ Ma and $\sim 1490$ $\mathrm{Ma}$ (Li et al., 2015). The oldest ages of hydrothermal minerals in the $\mathrm{Fe}$ and $\mathrm{Cu}$ deposits are molybdenite and chalcopyrite Re-Os ages of $\sim 1660 \mathrm{Ma}$ at the Yinachang Fe-Cu deposit (Zhao et al., 2013) and an age of $1653 \pm 18$ Ma for hydrothermal zircon with chalcopyrite and albite inclusions from $\mathrm{Cu}$ mineralisation at the Dahongshan Fe-Cu deposit, which is within error of the 
age of dolerites at the deposit (Zhao et al., 2017). Massive and banded magnetite-rich bodies with spatially associated albitisation, likened to Kiruna type IOA deposits, occur spatially separately from the $\mathrm{Cu}$ orebodies at this deposit and have been inferred to be temporally, spatially and genetically related to the $\sim 1660 \mathrm{Ma}$ dolerites (Zhao et al., 2017). The $\mathrm{Cu}-\mathrm{Au}$ mineralisation at Dahongshan is mostly of banded style with sulfides and associated biotite \pm garnet alteration along a strong tectonic foliation and, where magnetite is present, the $\mathrm{Cu}$-Fe sulfides postdate this oxide (Zhao et al., 2017). Overall, the first Fe and Cu event(s) at 1660 Ma in the Kangdian $\mathrm{Cu}$ province appear to have occurred not long after deposition of the sedimentary and volcanic host rocks. The geochemical compositions of the volcanic and mafic intrusive rocks have been interpreted to indicate an intracontinental extensional setting (Zhao \& Zhou, 2011; Zhou et al., 2014).

A large number of ages younger than 1660 Ma have been reported for other Fe and $\mathrm{Cu}$ deposits in the Kangdian $\mathrm{Cu}$ province, for example at $\sim 1450 \mathrm{Ma}, \sim 1050-1070 \mathrm{Ma}$ and $\sim 880-850 \mathrm{Ma}$ (Chen \& Zhou, 2014; Zhou et al., 2014; see also summaries in Zeng et al., 2018 and Lin et al., 2020). Of particular note are ${ }^{40} \mathrm{Ar}-{ }^{39} \mathrm{Ar}$ ages of $\sim 851 \mathrm{Ma}$ to $\sim 817 \mathrm{Ma}$ for biotite and amphibole within several of the $\mathrm{Fe}-\mathrm{Cu}$ deposits which are interpreted as recording a major regional Neoproterozoic tectonothermal event (Zhou et al., 2014). These align roughly with the $\sim 880-850 \mathrm{Ma}$ ages of some allanite at the Lala deposit (Chen \& Zhou, 2014) and molybdenite with chalcopyrite in the Dahongshan deposit (833 \pm 9 Ma to $799 \pm 13$ Ma, Zhao et al., 2017). Indeed, descriptions of the $\mathrm{Fe}-\mathrm{Cu}$ ores indicate intense ductile to brittle-ductile deformation features in the $\mathrm{Cu}$-sulfide ores of many of the Kangdian deposits. Interestingly, the period 860-740 Ma was also marked by arc granites, adakitic rocks, and subduction-related mafic-ultramafic rocks (Zhou et al., 2002, 2014).

Although much less published information is available for the SSC deposits than for the $\mathrm{Fe}-\mathrm{Cu}$ deposits in the Kangdian $\mathrm{Cu}$ province, some of these deposits are large (e.g. Hongnipo deposit, 4.3 Bt @ $1.42 \% \mathrm{Cu}$; Lin et al., 2020). They appear to lack significant modal amounts of iron oxides and contain mineralisation of both stratiform appearance and transgressive vein styles; the latter hosts most of the $\mathrm{Cu}$ mineralisation at the Hongnipo deposit (Lin et al., 2020). The stratiform sulfides occur along a tectonic foliation (sub)parallel to compositional layering (see Fig. 4 of Lin et al., 2020), similar to the form of banded $\mathrm{Cu}-\mathrm{Au}$ mineralisation in some of the $\mathrm{Fe}-\mathrm{Cu}$ deposits such as Dahongshan and Lala. Geochronological data are few and imprecise for the SSC deposits but may indicate an initial $\mathrm{Cu}$ mineralising event at $1.6 \mathrm{Ga}$ (Lin et al., 2020). Although a VMS origin was suggested by Lin et al. (2020), the mineralisation alternatively may be of diagenetic or even syn-tectonic origin. The relationships between the SSC and Fe-Cu deposits remain unclear.

Recent models of ore genesis for the Kangdian Cu province favour an early ( $\sim 1660 \mathrm{Ma}$ ) stage Feoxide and at least some $\mathrm{Cu}-\mathrm{Au}$ hydrothermal activity genetically linked to emplacement of mafic intrusions within an extensional basinal setting and involving both magmatic-hydrothermal and basin-derived fluids (e.g. Zhao et al., 2017). Later, syn-metamorphic and syn-deformational features of the ores have been interpreted to represent remobilisation of earlier $\mathrm{Cu}$-Au ores, with or without new hydrothermal activity during superimposed tectonothermal events (e.g. Zhao et al., 2017). However, detailed structural study of the Lala deposit has correlated gabbro intrusion and the formation of most magnetite and albitisation with the regional extension-related $\sim 1660$ $\mathrm{Ma}$ events, whereas the main $\mathrm{Cu}-\mathrm{Fe}$ sulfide mineralisation and additional magnetite was correlated with compressional deformation during the Sabie orogeny at $\sim 1050 \mathrm{Ma}$ (Zeng et al., 2018). Later biotite-sulfide veins cutting banded $\mathrm{Cu}$-Fe ore were interpreted as syn-extensional at 851-817 Ma (Zeng et al., 2018).

In summary, the available data for the Kangdian province seem permissive of not only remobilisation but of introduction of significant new $\mathrm{Cu}-\mathrm{Au}-\mathrm{Fe}$ mineralisation during either or both of the $\sim 1050 \mathrm{Ma}$ and $\sim 851-817 \mathrm{Ma}$ tectonothermal (orogenic?) events affecting the metallogenic province. It is presently unclear whether the latter tectonothermal event was pre-, syn- or post-arc magmatism. 
The Sin Quyen Fe-Cu-Au-REE deposit in northern Vietnam (52.8 Mt @ $0.91 \% \mathrm{Cu}, 0.41 \mathrm{~g} / \mathrm{t}$ Au and $0.7 \%$ combined Ce, La, Pr and Nd) is situated within the Red River fault zone to the south of the Yangzte craton (McLean, 2002). Earlier work proposed that the host metamorphic sequences could be correlated with the sequence hosting $\mathrm{Fe}-\mathrm{Cu}$ deposits in the Kangdian Cu province, with displacement of the Sin Quyen area along the Red River fault zone (Zhou et al., 2014). Host rocks are highly deformed amphibolite facies gneisses and schists including a lower, graphitic, unit and an upper unit of felsic and mafic orthogneisses which hosts most of the $\mathrm{Cu}-\mathrm{Au}$-REE mineralisation and related alteration. Recent geochronology has shown that the host sequence is in fact younger than the Fe-Cu-hosting <1742-1681 Ma sequence in the Kangdian province, with depositional ages of 870-830 Ma for this part of the Sin Quyen Formation (Liu \& Chen, 2019). Other parts of the host rock sequence, however, are of similar Paleoproterozoic age to those in the Kangdian $\mathrm{Cu}$ provinces (Liu \& Chen, 2019). Iron-potassic-calcic alteration and some sulfide mineralisation are distributed along a strong tectonic foliation, and comprise an early stage of magnetite with amphiboles, hedenbergite and allanite, and a later stage with initial chalcopyrite-pyrrhotitepyrite along the foliation and a latest, volumetrically dominant, and undeformed chalcopyritepyrrhotite assemblage (McLean, 2002; Li \& Zhou, 2018; Liu \& Chen, 2019). Dating of hydrothermal zircon and monazite from the early magnetite-allanite hydrothermal stage has yielded ages of $841 \pm 12 \mathrm{Ma}$ and $836 \pm 18 \mathrm{Ma}$ (Li et al., 2018), similar to the timing of tectonothermal and arc-related igneous activity regionally within and near the Kangdian $\mathrm{Cu}$ province (Zhou et al., 2014). These results support the notion that the terrane hosting the Sin Quyen deposit is a tectonically displaced southern extension of the Kangdian Cu province in China ((X. C. Li et al., 2018; Liu \& Terry Chen, 2019; Zhou et al., 2014)).

\section{Khetri province, India - Neoproterozoic $\mathrm{Cu}-\mathrm{Au}$ deposits}

The Khetri copper province in Rajasthan is situated within the northwestern part of the AravalliDelhi Orogenic Belt, a Proterozoic deformed sedimentary-volcanic sequence along and overlying the western margin of the Archean-Proterozoic Bundelkund craton (Knight et al., 2002). Significant resources of $\mathrm{Cu}-\mathrm{Au}$ are present in the Khetri area in Fe-oxide-rich deposits, for example $30 \mathrm{Mt} @ 1.7$ \% Cu, 0.3-1.3 g/t Au at the Banwas deposit, $66 \mathrm{Mt} @ 1.12-1.71 \% \mathrm{Cu}$ and $0.2-2 \mathrm{~g} / \mathrm{t} \mathrm{Au}$ at the Madan-Kudan deposit, and $40 \mathrm{Mt} @ 1.14-1.62 \% \mathrm{Cu}$ and $0.2 \mathrm{~g} / \mathrm{t} \mathrm{Au}$ at the Kolihan and Chandmari deposits (Knight et al., 2002; Bhardwaj et al., 2014 cited in Li et al., 2019). Additionally, the region contains several groups of sedimentary stratiform $\mathrm{Cu}$ (or SSC) Kaur et al., 2017deposits that are zoned from pyrite-chalcopyrite to bornite and chalcocite and have been likened to 'redbed' Cu deposits in the Central African Copper Belt (e.g. Mukhopadhyay et al., 2019) or have affinities with IOCG deposits (Sharma et al., 2020).

Host rocks of both the $\mathrm{Cu}-\mathrm{Au}-\mathrm{Fe}$ and SSC type deposits are the Delhi Supergroup, which in the Khetri-Alwar region comprise a 1.7-1.5 Ga dominantly siliciclastic sequence with minor carbonate and mafic volcanic rocks (Kaur et al., 2017). This sequence is age-equivalent to parts of the Aravalli Supergroup in the southern part of the Aravalli-Delhi Orogenic Belt, which also hosts $\mathrm{Au}(-\mathrm{Cu}-\mathrm{Fe})$ mineralisation in albitite-carbonate rocks in the Bhukia district (Fareeduddin et al., 2012; Mukherjee et al., 2019). An environment of deposition along an active Andean-type convergent margin has been suggested for the Aravalli Supergroup and equivalents in the Delhi Supergroup (McKenzie et al., 2013). Although the Delhi Supergroup was multiply deformed and metamorphosed there are few timing high-precision geochronological constraints on tectonothermal activity. The youngest tectonothermal event reported by Ozha et al. (2016) based on monazite U-Pb EPMA dating is $\sim 1.05-0.99$ Ga which these authors related to the amalgamation of Rodinia. However, the extensive suite of felsic intrusions of the 870-800 Ma Erinpura Suite along the western margin of the Aravalli-Delhi Orogenic Belt is highly tectonised and migmatised in places (Just et al., 2011). Whereas the Erinpura Suite was previously interpreted to be syntectonic, which is supported by dating work reported in several studies (e.g. see Kaur et al., 2017), Just et al. (2011) proposed that the tectonothermal overprint occurred significantly later, at 
780-736 Ma and partly coeval with emplacement of the bimodal Malani Suite intrusions and volcanic rocks.

In this context, the recently determined ages for hydrothermal monazite in $\mathrm{Cu}-\mathrm{Au}$-Fe deposits in the Khetri Cu province ( $833 \pm 5 \mathrm{Ma}$ to $840 \pm 6 \mathrm{Ma}$, U-Pb LA-ICPMS dates) overlap with the ages of the Erinpura Suite (Li et al., 2019). It is also evident that regional-scale sodic alteration in the Khetri $\mathrm{Cu}$ province also developed at a similar time $(\sim 847-831 \mathrm{Ma})$ to the $\mathrm{Cu}-\mathrm{Au}-\mathrm{Fe}$ mineralisation, based on a titanite U-Pb SIMS dating and a Sm-Nd isochron age for scapolitealtered pyroxenite (Knight et al., 2002; Kaur et al., 2013). The timing of this sodic metasomatism and $\mathrm{Cu}-\mathrm{Au}-\mathrm{Fe}$ mineralisation in relation to metamorphism remains unclear, although a post-peak timing seems probable (Knight et al., 2002). Nevertheless, chalcopyrite-pyrrhotite-pyritemagnetite mineralisation and associated amphibole-biotite-albite-garnet-carbonate-bearing alteration exhibit strong structural controls such as fault-controlled en echelon ore shoots, sulfidic bands along the tectonic foliation, and later sulfidic veins that cut this foliation (Knight et al., 2002). The author's observations at several of the deposits supports the proposal that some mineralisation postdates deformation fabrics (Knight et al., 2002) but there are significant proportions of the mineralisation that either were synchronous with, or predated, the brittleductile deformation that produced the main tectonic foliation.

\section{Chilean and Peruvian Andes - IOA and Cu-Au-Fe deposits}

Iron oxide-rich $\mathrm{Cu}-\mathrm{Au}$ deposits of Cretaceous age are distributed in two principal belts in the Andes, one in northern Chile hosting the large Candelaria, Mantoverde and other $\mathrm{Cu}-\mathrm{Au}$ deposits and a second, less endowed, belt in southern Peru hosting the Raúl-Condestable and Mina Justa $\mathrm{Cu}-\mathrm{Au}$ deposits. Whereas many of these deposits have been classified as members of the IOCG family (e.g. (Sillitoe, 2003; Williams et al., 2005; Groves et al., 2010; Barton, 2013; Chen et al., 2013), the two belts of iron oxide-rich $\mathrm{Cu}-\mathrm{Au}$ deposits also contain, or lie adjacent to, groups of other Cretaceous deposit types including IOA, porphyry $\mathrm{Cu}-\mathrm{Au}(-\mathrm{Mo})$, skarn $\mathrm{Fe} \pm \mathrm{Cu}-\mathrm{Au}$ and 'manto' $\mathrm{Cu}(-\mathrm{Ag})$ deposits. The large Fe resources in northern Chile define the Chilean Iron Belt (CIB;Oyarzun et al., 2003). These relatively well preserved Andean metallogenic provinces are important not only economically but also are useful in understanding the genetic relationships between the differing types of $\mathrm{Fe}$ and $\mathrm{Cu}-\mathrm{Au}$ deposits. The timing and regional geological settings of the deposits is crucial in deciphering such relationships, which has been aided by the availability of considerable new data in recent years. Here we focus on timing constraints determined from the more robust geochronometers such as zircon $\mathrm{U}-\mathrm{Pb}$ dating of igneous rocks, and $\mathrm{U}-\mathrm{Pb}, \mathrm{Re}-\mathrm{Os}$ and Ar-Ar dating of selected hydrothermal minerals with higher closure temperatures such as titanite, apatite, molybdenite, amphibole and biotite. We place less emphasis on some of the earlier geochronology using $\mathrm{K}-\mathrm{Ar}$ and $\mathrm{Rb}-\mathrm{Sr}$ methods on whole-rock, $\mathrm{K}$ feldspar and sericite/clay samples which can be vulnerable to fluid-induced disturbance and thermal resetting.

The broad setting for the Cretaceous $\mathrm{Fe}$ and $\mathrm{Cu} \pm \mathrm{Au}$ deposits or northern Chile and southern Peru is a convergent margin situated over a long-lived and still-active subduction system (Sillitoe, 2003; Chen et al., 2013. A major transition occurred during the Late Cretaceous when Jurassic magmatic arc and sedimentary back-arc basin rocks that formed within an extensional tectonic setting were subjected to inversion. This transition to a compressive setting has been the subject of many studies and is now thought to have been diachronous from south to north and may have commenced as early as 130-122 Ma at latitudes of $40^{\circ}-46^{\circ} \mathrm{S}$ (Gianni et al., 2020). However at the latitudes of the CIB and partly co-located $\mathrm{Cu}-\mathrm{Au}-\mathrm{Fe}$ deposits (e.g. $20^{\circ}-33^{\circ} \mathrm{S}$ ) the onset of inversion of the Jurassic arc and basin system has been refined to the period $\sim 107-105$ Ma with a main phase of compression at 100-95 Ma (Bascunán et al., 2016; Fennell et al., 2017; Boyce et al., 2020). This tectonic switch was also preceded by a major decrease in the flux of arc magmas from $\sim 140$ Ma to $\sim 100 \mathrm{Ma}$ and a change from dominantly intermediate-composition dioritic/andesitic igneous rocks to tonalitic and dioritic/andesitic compositions at $\sim 100 \mathrm{Ma}$ (Fig. S1, Girardi, 2014). 
Strike-slip movement along the arc-parallel Atacama Fault System (AFS), which accommodated northwest to southeast directed plate convergence, was initially ductile at $135-120 \mathrm{Ma}$ at depths of $\sim 5-7 \mathrm{~km}$ where movement was facilitated by thermal weakening, and then transitioned to brittle behaviour until $\sim 110 \mathrm{Ma}$ (latitudes $24^{\circ}-28^{\circ}$ S, Seymour et al., 2020).

The metallogenic evolution appears to have evolved in parallel with these tectonic and magmatic transitions. An early stage of large iron oxide deposits formed in Peru along with stratabound epigenetic 'manto' $\mathrm{Cu}(-\mathrm{Ag})$ deposits in Chile in the Jurassic rocks around 164-155 Ma (e.g. Marcona: Hawkes et al., 2002; Chen et al., 2010a, 2010b; 2013; Mantos Blancos and Michilli manto district: Maksaev \& Zentilli, 2002; Tristá-Aguilera et al., 2006; Oliveros et al., 2008). The main stage of large iron oxide-apatite deposits of the CIB, together with iron oxide-rich $\mathrm{Cu}$-Au deposits and a second manto $\mathrm{Cu}$-forming event, occurred in the Late Cretaceous between $\sim 130 \mathrm{Ma}$ and $\sim 85 \mathrm{Ma}$. The few available dates for Cretaceous manto $\mathrm{Cu}(-\mathrm{Ag})$ deposits indicate alteration at 106-101 Ma, based on K-feldspar ${ }^{40} \mathrm{Ar}-{ }^{39} \mathrm{Ar}$ dating (El Soldado deposit, Wilson et al., 2003). Despite the paucity of high-precision ages using robust geochronometers for the $\mathrm{Fe}$ and $\mathrm{Cu}-\mathrm{Au}$ deposits, the available data show a possible sequence from IOA to $\mathrm{Cu}-\mathrm{Au}-\mathrm{Fe}$ to finally manto $\mathrm{Cu}(-$ $\mathrm{Ag}$ ) deposits, and with small porphyry $\mathrm{Cu}$ deposits sporadically throughout the $\sim 130-85 \mathrm{Ma}$ period (Fig. S1). The few high-precision age constraints IOA deposits include the Carmen and nearby IOA deposits $(131.0 \pm 1.0 \mathrm{Ma}$, apatite-magnetite U-Pb age; $126.8 \pm 1.9 \mathrm{Ma}$, actinolite alteration, ${ }^{40} \mathrm{Ar}-{ }^{39} \mathrm{Ar}$ plateau age; Gelcich et al., 2005), the El Romeral deposit (127.7 $\pm 1.5 \mathrm{Ma}$, amphibole alteration, ${ }^{40} \mathrm{Ar}-{ }^{39} \mathrm{Ar}$ plateau age; Rojas et al., 2018), and a minimum age of $127.1 \pm 0.7$ Ma for the Dominga IOA deposit constrained by a Re-Os age for molybdenite in allanitechalcopyrite-bearing breccia cutting the IOA deposit (Veloso et al., 2017). The age of IOA formation at the Dominga deposit is supported by an imprecise apatite U-Pb age of $127 \pm 15 \mathrm{Ma}$ (Veloso et al., 2017). These 131-127 Ma ages are within error of the ages of abundant dioritic intrusions in the CIB which in many cases are proximal to the IOA deposits (e.g. Rojas et al., 2018; Seymour et al., 2020). Control of the sites of the large IOA deposits by sinistral strike-slip movement on regional shear zones linked to the AFS (e.g. Bookstrom, 1977) appears to be consistent with recently proposed timing constraints on ductile and then brittle movement on the AFS during the period 135-120 Ma (Seymour et al., 2020). This would place such IOA deposit formation well within the extension/transtension stage of Cretaceous Andean evolution rather than during the later compressional/transpressional regime, although local zones of transpression also may have controlled IOA formation along parts of the AFS (Oyarzun et al., 2003). The significance of a possible younger phase of IOA formation, recorded by a $\mathrm{Pb}$-Th age of $116 \pm 4 \mathrm{Ma}$ for titanite associated with Na-Ca alteration at the Cerro Negro Norte magnetite (apatite) deposit (Raab, 2001), has yet to be determined. Other mineralisation that formed at $\sim 130$ Ma includes small-medium sized porphyry $\mathrm{Cu}-\mathrm{Au}-\mathrm{Mo}$ deposits such as Productora, which was recently re-categorised from the IOCG class (Ray \& Dick, 2002; Richards et al., 2017) to the porphyry copper class $(130.1 \pm 0.6 \mathrm{Ma}$, molybdenite Re-Os age, Escolme et al., 2020).

Many of the large IOA deposits in the CIB contain minor pyrite and in places minor chalcopyrite, and there has been much debate on the timing, origin and significance of such sulfides in relation to IOCG deposit formation (e.g. Sillitoe, 2003; Knipping et al., 2015; Reich et al., 2016; Simon et al., 2018; Childress et al., 2020 Sillitoe, 2003; Knipping et al., 2015; Simon et al., 2018; Childress et al., 2020). Unfortunately there appears to be a lack of geochronological data that relate clearly to the formation of the minor copper sulfides in IOA deposits in the CIB. Texturally, copper sulfides are almost invariably described as 'late' with respect to magnetite (-apatite) formation, and are commonly associated with very different mineral assemblages to those associated with massive and vein style magnetite (-apatite). For example at the Cerro Negro Norte IOA deposit small $\mathrm{Cu}-\mathrm{Au}$ resources (e.g. $0.55 \mathrm{Mt} @ 0.24 \% \mathrm{Cu}$ and $1.4 \mathrm{~g} / \mathrm{t} \mathrm{Au}$ ) are associated with pyritechalcopyrite-bearing quartz-feldspar-tourmaline veins that cross-cut magnetite-actinolitescapolite-titanite-apatite assemblages (Raab, 2001). Moreover, copper mineralisation is also present separately from IOA deposits in the Cerro Negro Norte district, within a broad zone of tourmaline-quartz alteration (Raab, 2001). More broadly, Sillitoe (2003) noted that nowhere in 
the CIB are complete transitions observable from IOA to IOCG deposits even though $\mathrm{Cu}$ is present at low levels in some IOA deposits. Whether the paragenetically early magnetite that is present in many of the $\mathrm{Cu}-\mathrm{Au}-\mathrm{Fe}$ deposits is of IOA origin or is not directly related to IOA deposits is an unresolved question in the CIB.

The earliest examples of $\mathrm{Cu} \pm \mathrm{Au}$ mineralisation that formed coevally with abundant iron oxides are several 'IOCG veins' where associated actinolite alteration ${ }^{40} \mathrm{Ar}-{ }^{39} \mathrm{Ar}$ ages of $\sim 120 \mathrm{Ma}$ have been reported (e.g. 117.8 \pm 1.9 Ma, Todos Los Santos prospect, Gelcich et al., 2005; and $121.9 \pm$ 1.5 Ma and $119.8 \pm 1.6 \mathrm{Ma}$, El Trapiche prospect, Creixell et al., 2009). This timing is consistent with K-Ar ages of hydrothermal sericite alteration at the large Mantoverde iron oxide-rich $\mathrm{Cu}-\mathrm{Au}$ deposit (117 \pm 3 Ma and $121 \pm 3 \mathrm{Ma}$, Vila et al., 1996), and a two-point Re-Os isochron possible age of $\sim 116$ Ma for this deposit (Mathur, 2002). The best available age constraints for iron oxiderich $\mathrm{Cu}-\mathrm{Au}$ deposits are molybdenite Re-Os and amphibole and biotite ${ }^{40} \mathrm{Ar}-{ }^{39} \mathrm{Ar}$ ages from the large Candelaria $\mathrm{Cu}-\mathrm{Au}$ deposit, which cluster around 116-114 Ma and 112-110 Ma (Marschik \& Fontboté, 2001; Mathur et al., 2002). The timing of alteration at the Raul-Condestable $\mathrm{Cu}-\mathrm{Au}$ deposit in Peru is also tightly constrained by a titanite U-Pb age of $115.2 \pm 0.3 \mathrm{Ma}$, which is the same age (within error) of subjacent tonalitic intrusions (de Haller et al., 2006). These ages place the formation of the earliest 'IOCG' veins and the major $\mathrm{Cu}-\mathrm{Au}-\mathrm{Fe}$ deposits at Candelaria and possibly Mantoverde towards the end of the extensional phase of Andean Jurassic-Cretaceous evolution (Sillitoe, 2003), coincident with thermally-enhanced major sinistral strike-slip movement on the AFS (Seymour et al., 2020). Indeed, syn-extensional timing of mineralisation has been proposed for the Candelaria deposit by Oyarzun et al., 2003 and Arévalo et al. (2006).

Several iron oxide-rich $\mathrm{Cu}-\mathrm{Au}$ deposits in Chile and Peru record ages in the range $\sim 110-84 \mathrm{Ma}$ (Richards et al., 2017), but the significance of many of the reported ages is unclear. For example, whereas at Mina Justa (Peru) $\sim 111-110 \mathrm{Ma}{ }^{40} \mathrm{Ar}-{ }^{39} \mathrm{Ar}$ ages for actinolite are likely a robust record of the timing of magnetite alteration because of the relatively high closure temperature for actinolite, ${ }^{40} \mathrm{Ar}-{ }^{39} \mathrm{Ar}$ ages of $\sim 104-95 \mathrm{Ma}$ from adularia associated with copper mineralisation (Chen et al., 2010a) may represent cooling ages rather than the timing of copper introduction, on account of the relatively low closure temperatures for adularia. Adding to the uncertainty in the significance of the 110-84 Ma ages of some $\mathrm{Cu}-\mathrm{Au}$-Fe deposits, copper deposits of undoubted porphyry $\mathrm{Cu}(-\mathrm{Au}-\mathrm{Mo})$ affiliation with broadly similar ages to both the iron oxide-rich $\mathrm{Cu}-\mathrm{Au}$ and IOA deposits (Richards et al., 2017) are also present within and adjacent to the CIB (Sillitoe, 2003; Richards et al., 2017). For example, the Tropezón $\mathrm{Cu}-\mathrm{Mo}(-\mathrm{Au})$ deposit has been included within the IOCG family (e.g. Richards et al., 2017) yet was considered by Tornos et al. (2010) as transitional between an IOCG and a porphyry $\mathrm{Cu}$ deposit. The age of the host quartz diorite to tonalite stock $(110.0 \pm 2.1 \mathrm{Ma})$ therefore may be close to either the timing of iron oxide-rich porphyry style mineralisation or the timing of a hybrid style of IOCG deposit. A third case is the El Espino $\mathrm{Cu}-\mathrm{Au}$ deposit which has been described as an IOCG deposit, and has been dated at $~ 88$ $86 \mathrm{Ma}$ (actinolite, sericite and K-feldspar ${ }^{40} \mathrm{Ar}-{ }^{39} \mathrm{Ar}$ ages, Lopez et al., 2014). If this deposit is of IOCG affinity, its age would imply the presence of a significantly younger $\mathrm{Cu}-\mathrm{Au}-\mathrm{Fe}$ event than that forming the La Candelaria deposit.

In summary, variably apatite-rich magnetite IOA deposits without significant $\mathrm{Cu}-\mathrm{Au}$ formed at $\sim 130 \mathrm{Ma}$, prior to commencement of the main stage of iron oxide-rich $\mathrm{Cu}$ - $\mathrm{Au}$ mineralisation at 120-110 Ma. Relatively small porphyry Cu-Au-Mo deposits also formed across this 130-110 Ma metallogenic period, which occurred within an overall extensional to transtensional tectonic regime mostly prior to, but also perhaps overlapping with (Chen et al., 2013), the onset of inversion tectonism at 107-100 Ma regime in northern Chile when arc-related magmatism was waning. Strike-slip brittle-ductile to brittle deformation on the Atacama Fault System, enhanced by intrusion-induced thermal softening, appears to have partly controlled the locations of some of the larger IOA and $\mathrm{Cu}-\mathrm{Au}$-Fe deposits. Although minor iron oxide-rich $\mathrm{Cu}-\mathrm{Au}$ deposits may have continued to form during the early stages of inversion it appears that manto $\mathrm{Cu}(-\mathrm{Ag})$ and small porphyry $\mathrm{Cu}$ and affiliated deposits were the dominant types of mineralisation during the 
compressional regime in the Late Cretaceous. Hybrid mineralisation styles may have developed where later hydrothermal systems (e.g. porphyry, skarn, manto) overprinted earlier mineralisation (e.g. $\mathrm{Cu}-\mathrm{Au}-\mathrm{Fe}, \mathrm{IOA})$.

\section{References (for Supplementary Information)}

Acosta-Góngora, P., Gleeson, S. A., Samson, I. M., Corriveau, L., Ootes, L., Taylor, B. E., Creaser, R. A., \& Muehlenbachs, K. (2015). Genesis of the Paleoproterozoic NICO iron oxide-cobalt-gold-bismuth deposit, Northwest Territories, Canada: Evidence from isotope geochemistry and fluid inclusions. Precambrian Research, 268, 168-193. https://doi.org/10.1016/j.precamres.2015.06.007

Arévalo, C., Grocott, J., Martin, W., Pringle, M., \& Taylor, G. (2006). Structural setting of the Candelaria Fe oxide $\mathrm{Cu}-\mathrm{Au}$ deposit, Chilean Andes (2730' S). Economic Geology, 101(4), 819-841. https://doi.org/10.2113/gsecongeo.101.4.819

Armistead, S. E., Betts, P. G., Ailleres, L., Armit, R. J., \& Williams, H. A. (2018). Cu-Au mineralisation in the Curnamona Province, South Australia: A hybrid stratiform genetic model for Mesoproterozoic IOCG systems in Australia. Ore Geology Reviews, 94(September 2017), 104117. https://doi.org/10.1016/j.oregeorev.2018.01.024

Ashley, P. M., Cook, N. D. J., \& Fanning, C. M. (1996). Geochemistry and age of metamorphosed felsic igneous rocks with A-type affinities in the Willyama Supergroup, Olary Block, South Australia, and implications for mineral exploration. Lithos, 38(3-4), 167-184. https://doi.org/10.1016/0024-4937(96)00011-4

Ashley, P. M., Lawie, D. C., Conor, C. H. H., \& Plimer, I. R. (1997). Geology of the Olary Domain, Curnamona Province, South Australia and field guide to 1997 excursion stops. Report Book.

Austin, J. R., \& Blenkinsop, T. G. (2010). Cloncurry fault zone: Strain partitioning and reactivation in a crustal-scale deformation zone, mt isa inlier. Australian Journal of Earth Sciences, 57(1), 1-21. https://doi.org/10.1080/08120090903416187

Babo, J., Spandler, C., Oliver, N. H. S., Brown, M., Rubenach, M. J., \& Creaser, R. A. (2017). The highgrade mo-Re Merlin deposit, Cloncurry district, Australia: Paragenesis and geochronology of hydrothermal alteration and ore formation. Economic Geology, 112(2), 397-422. https://doi.org/10.2113/econgeo.112.2.397

Baker, T., \& Laing, W. P. (1998). Eloise Cu-Au deposit, East Mt Isa Block: Structural environment and structural controls on ore. Australian Journal of Earth Sciences, 45(3), 429-444. https://doi.org/10.1080/08120099808728402

Barton, M. D. (2013). Iron Oxide(-Cu-Au-REE-P-Ag-U-Co) Systems. In Treatise on Geochemistry: Second Edition (Vol. 13, pp. 515-541). Elsevier Inc. https://doi.org/10.1016/B978-0-08095975-7.01123-2

Bascuñán, S., Arriagada, C., le Roux, J., \& Deckart, K. (2016). Unraveling the Peruvian Phase of the Central Andes: Stratigraphy, sedimentology and geochronology of the Salar de Atacama Basin (22 $\left.{ }^{\circ} 30-23^{\circ} \mathrm{S}\right)$, northern Chile. Basin Research, 28(3), 365-392. https://doi.org/10.1111/bre.12114

Bergman, S., Billström, K., Persson, P. O., Skiöld, T., \& Evins, P. (2006). U-pb age evidence for repeated palaeoproterozoic metamorphism and deformation near the pajala shear zone in the northern fennoscandian shield. Gff, 128(1), 7-20. https://doi.org/10.1080/11035890601281007

Bergman, S., Kübler, L., \& Martinsson, O. (2001). Description of regional geological and geophysical maps of northern Norrbotten County (east of the Caledonian orogen).

Bettencourt, J. S., Juliani, C., Xavier, R. P., Monteiro, L. V. S., Bastos Neto, A. C., Klein, E. L., Assis, R. R., Leite, W. B., Moreto, C. P. N., Fernandes, C. M. D., \& Pereira, V. P. (2016). Metallogenetic systems associated with granitoid magmatism in the Amazonian Craton: An overview of the present 
level of understanding and exploration significance. Journal of South American Earth Sciences, 68(May), 22-49. https://doi.org/10.1016/j.jsames.2015.11.014

Betts, P. G., Giles, D., Foden, J., Schaefer, B. F., Mark, G., Pankhurst, M. J., Forbes, C. J., Williams, H. A., Chalmers, N. C., \& Hills, Q. (2009). Mesoproterozoic plume-modified orogenesis in eastern Precambrian Australia. Tectonics, 28(3), 1-28. https://doi.org/10.1029/2008TC002325

Bierlein, F. P., Ashley, P. M., \& Plimer, I. R. (1995). Sulphide mineralisation in the Olary Block, South Australia - Evidence for syn-tectonic to late-stage mobilisation. Mineralium Deposita, 30(6), 424-438. https://doi.org/10.1007/BF00196402

Billström, K., Evins, P., Martinsson, O., Jeon, H., \& Weihed, P. (2019). Conflicting zircon vs. titanite U$\mathrm{Pb}$ age systematics and the deposition of the host volcanic sequence to Kiruna-type and IOCG deposits in northern Sweden, Fennoscandian shield. Precambrian Research, 321(December 2018), 123-133. https://doi.org/10.1016/j.precamres.2018.12.003

Billström, Kjell, Eilu, P., Martinsson, O., Niiranen, T., Broman, C., Weihed, P., \& Wanhainen, C. (2010). IOCG and related mineral deposits of the northern Fennoscandian Shield. In T. M. Porter (Ed.), Hydrothermal iron oxide copper-gold and related deposits: A global perspective, Volume 4 (pp. 381-414). PGC Publishing.

Blake, D. H. (1987). Geology of the Mount Isa Inlier and environs, Queensland and Northern Territory. Bureau of Mineral Resources Bulletin 225.

Bookstrom, A. A. (1977). The magnetite deposits of El Romeral, Chile. Economic Geology, 72(6), 11011130. https://doi.org/10.2113/gsecongeo.72.6.1101

Bowden, B., Fraser, G., Davidson, G. J., Meffre, S., Skirrow, R., Bull, S., \& Thompson, J. (2017). Age constraints on the hydrothermal history of the Prominent Hill iron oxide copper-gold deposit, South Australia. Mineralium Deposita, 52(6), 863-881. https://doi.org/10.1007/s00126-016$0689-1$

Boyce, D., Charrier, R., \& Farías, M. (2020). The First Andean Compressive Tectonic Phase: Sedimentologic and Structural Analysis of Mid-Cretaceous Deposits in the Coastal Cordillera, Central Chile (3250'S). Tectonics, 39(2), 1-24. https://doi.org/10.1029/2019TC005825

Brown, M., \& Porter, T. M. (2010). The Mount Elliott IOCG system, Eastern Fold Belt, Mount Isa Inlier, northwest Queensland. In T. M. Porter (Ed.), Hydrothermal iron oxide copper-gold and related deposits: A global perspective, Volume 3 (pp. 219-231). PGC Publishing.

Budd, A. (2006). The Tarcoola Goldfeld of the central Gawler gold province, and the Hiltaba Association Granites, Gawler craton, South Australia: Unpublished PhD thesis.

Budd, A. R., \& Fraser, G. L. (2004). Geological relationships and 40Ar/39Ar age constraints on gold mineralisation at Tarcoola, central Gawler gold province, South Australia. Australian Journal of Earth Sciences, 51(5), 685-699. https://doi.org/10.1111/j.1400-0952.2004.01084.x

Budd, A. R., \& Skirrow, R. G. (2007). The nature and origin of gold deposits of the Tarcoola Goldfield and implications for the central Gawler Gold Province, South Australia. Economic Geology, 102(8). https://doi.org/10.2113/gsecongeo.102.8.1541

Carr, L. K., Korsch, R. J., Holzschuh, J., Costelloe, R. D., Meixner, A. J., Matthews, C., \& Godsmark, B. (2010). Geological interpretation of seismic reflection lines 08GA-C1 and 09TE-01: Arrowie Basin, South Australia. In R. J. Korsch \& N. Kositcin (Eds.), South Australian Seismic and MT Workshop 2010, Extended Abstracts, Record 2010/10 (pp. 54-65). Geoscience Australia.

Chen, H., Clark, A. H., \& Kyser, T. K. (2010). The Marcona magnetite deposit, Ica, south-central Peru: A product of hydrous, iron oxide-rich melts? Economic Geology, 105(8), 1441-1456. https://doi.org/10.2113/econgeo.105.8.1441

Chen, H., Clark, A. H., Kyser, T. K., Ullrich, T. D., Baxter, R., Chen, Y., \& Moody, T. C. (2010). Evolution of the giant Marcona-Mina Justa iron oxide-copper-gold district, South-Central Peru. Economic Geology, 105(1), 155-185. https://doi.org/10.2113/gsecongeo.105.1.155

Chen, H., Cooke, D. R., \& Baker, M. J. (2013). Mesozoic iron oxide copper-gold mineralization in the Central Andes and the Gondwana supercontinent breakup. Economic Geology, 108(1), 37-44. https://doi.org/10.2113/econgeo.108.1.37

Chen, W. T., \& Zhou, M. F. (2014). Ages and compositions of primary and secondary allanite from the Lala Fe-Cu deposit, SW China: Implications for multiple episodes of hydrothermal events. 
Contributions to Mineralogy and Petrology, 168(2), 1-20. https://doi.org/10.1007/s00410-0141043-1

Cherry, A. R., Ehrig, K., Kamenetsky, V. S., McPhie, J., Crowley, J. L., \& Kamenetsky, M. B. (2018). Precise geochronological constraints on the origin, setting and incorporation of ca. 1.59 Ga surficial facies into the Olympic Dam Breccia Complex, South Australia. Precambrian Research, 315(July), 162-178. https://doi.org/10.1016/j.precamres.2018.07.012

Childress, T. M., Simon, A. C., Reich, M., Barra, F., Arce, M., Lundstrom, C. C., \& Bindeman, I. N. (2020). Formation of the Mantoverde iron oxide-copper-gold (IOCG) deposit, Chile: insights from Fe and 0 stable isotopes and comparisons with iron oxide-apatite (IOA) deposits. Mineralium Deposita, 55(7), 1489-1504. https://doi.org/10.1007/s00126-019-00936-x

Ciobanu, C. L., Wade, B. P., Cook, N. J., Schmidt Mumm, A., \& Giles, D. (2013). Uranium-bearing hematite from the Olympic Dam Cu-U-Au deposit, South Australia: A geochemical tracer and reconnaissance $\mathrm{Pb}-\mathrm{Pb}$ geochronometer. Precambrian Research, 238, 129-147. https://doi.org/10.1016/j.precamres.2013.10.007

Claoué-Long, J., Maidment, D., \& Donnellan, N. (2008). Stratigraphic timing constraints in the Davenport Province, central Australia: A basis for Palaeoproterozoic correlations. Precambrian Research, 166, 204-218. https://doi.org/10.1016/j.precamres.2007.06.021

Claoué-Long, J., Maidment, D., Hussey, K., \& Huston, D. (2008). The duration of the Strangways Event in central Australia: Evidence for prolonged deep crust processes. Precambrian Research, 166(1-4), 246-262. https://doi.org/10.1016/j.precamres.2007.06.023

Clark, C., Schmidt Mumm, A., \& Faure, K. (2005). Timing and nature of fluid flow and alteration during Mesoproterozoic shear zone formation, Olary domain, South Australia. Journal of Metamorphic Geology, 23(3), 147-164. https://doi.org/10.1111/j.1525-1314.2005.00568.x

Compston, D. M. (1995). Time constraints on the evolution of the Tennant Creek Block, northern Australia. Precambrian Research, 71(1-4), 107-129. https://doi.org/10.1016/03019268(94)00058-Y

Compston, D. M., \& McDougall, I. (1994). 40Ar-39Ar and K-Ar Age Constraints on the Early Proterozoic Tennant Creek Block, Northern Australia, and the Age of Its Gold Deposits. Australian Journal of Earth Sciences, 41(6), 609-616. https://doi.org/10.1080/08120099408728171

Conor, C. H. H. (1995). Moonta-Wallaroo region - An interpretation of the geology of the Maitland and Wallaroo 1:100 000 sheet areas. Geological Survey of South Australia.

Conor, C., Raymond, O., Baker, T., Teale, G., Say, P., \& Lowe, G. (2010). Alteration and mineralisation in the Moonta-Wallaroo copper-gold mining field region, Olympic Domain, South Australia. In T. M. Porter (Ed.), Hydrothermal iron oxide copper-gold and related deposits: A global perspective, Volume 3 (pp. 147-170). PGC Publishing.

Conor, Colin H.H., \& Preiss, W. v. (2008). Understanding the 1720-1640 Ma Palaeoproterozoic Willyama Supergroup, Curnamona Province, Southeastern Australia: Implications for tectonics, basin evolution and ore genesis. Precambrian Research, 166(1-4), 297-317. https://doi.org/10.1016/j.precamres.2007.08.020

Conor, Colin, Raymond, O., Baker, T., Teale, G., Say, P., \& Lowe, G. (2010). Alteration and Mineralisation in the Moonta-Wallaroo Cu-Au Mining Field Region, Olympic Domain, South Australia. 147-170.

Cook, N. D. J., \& Ashley, P. M. (1992). Meta-evaporite sequence, exhalative chemical sediments and associated rocks in the Proterozoic Willyama Supergroup, South Australia: implications for metallogenesis. Precambrian Research, 56(3-4), 211-226. https://doi.org/10.1016/03019268(92)90102-T

Cook, N. D. J., Fanning, C. M., \& Ashley, P. M. (1994). New geochronological results from the Willyama Supergroup, Olary Block, South Australia. Australian Research on Ore Genesis Symposium, Adelaide, South Australia, December 12-14 1994.

Corriveau, L., Montreuil, J. F., \& Potter, E. G. (2016). Alteration facies linkages among iron oxide copper-gold, iron oxide-apatite, and affiliated deposits in the Great Bear magmatic zone, Northwest Territories, Canada. Economic Geology, 111(8), 2045-2072.

https://doi.org/10.2113/econgeo.111.8.2045 
Corriveau, L., Williams, P. . J., \& Mumin, H. (2010). Alteration vectors to IOCG mineralization from uncharted terranes to deposits. In Exploring for iron oxide copper-gold deposits: Canada and global analogues (pp. 89-110). Geological Association of Canada, Short Course Notes, Volume 20.

Corriveau, Louise. (2007). Iron oxide copper-gold deposits: A Canadian perspective. In W. Goodfellow (Ed.), Mineral deposits in Canada: A synthesis of major deposit types, district metallogeny, the evolution of geological provinces and exploration methods (pp. 307-328). Geological Association of Canada, Mineral Deposits Division, Special Publication Volume 5.

Corriveau, Louise, Mumin, A. H., \& Setterfield, T. (2010). IOCG environments in Canada: Characteristics, geological vectors to ore and challenges. In T. M. Porter (Ed.), Hydrothermal iron oxide copper-gold and related deposits: A global perspective, Volume 4 (pp. 311-344). PGC Publishing.

Courtney-Davies, L., Ciobanu, C. L., Verdugo-Ihl, M. R., Dmitrijeva, M., Cook, N. J., Ehrig, K., \& Wade, B. P. (2019). Hematite geochemistry and geochronology resolve genetic and temporal links among iron-oxide copper gold systems, Olympic Dam district, South Australia. Precambrian Research, 335(June), 105480. https://doi.org/10.1016/j.precamres.2019.105480

Cowley, W. M. (compiler). (2008). Solid geology of South Australia: Archaean to Early Mesoproterozoic time slice map. Geological Survey of South Australia.

https://sarigbasis.pir.sa.gov.au/WebtopEw/ws/samref/sarig1/wcir/Record?r=0\&m=1\&w=cat no $=2038279$

Craveiro, G. S., Villas, R. N. N., \& Xavier, R. P. (2020). A fluid inclusion and stable isotope (O, H, S and C) study of the Archean IOCG Cristalino deposit, Carajás Mineral Province, Brazil: Implications to ore genesis. Ore Geology Reviews, 127(August), 103822. https://doi.org/10.1016/j.oregeorev.2020.103822

Creixell, C., Arévalo, C., \& Fanning, C. M. (2009). Geochronology of the cretaceous magmatism from the Coastal Cordillera of north-central Chile ( $29^{\circ} 15^{\prime}$ to $29^{\circ} 30^{\prime}$ S ): metallogenic implications. XII Congreso Geológico Chileno, Santiago, 22-26 Noviembre, 2009, 3 p.

Cross, A. J., Clark, A. D., Schofield, A., Kositcin, N., Creek, T., Isa, M., \& Supersuite, T. (2020). New SHRIMP U-Pb zircon and monazite geochronology of the East Tennant region: a possible undercover extension of the Warramunga Province, Tennant Creek. Geoscience Australia, Exploring for the Future, Extended Abstract Volume, 1-4. https://doi.org/http://dx.doi.org/10.11636/132771

Cuison, A. G., Osborne, G. A., Russell, S. C., \& Bills, R. T. (2014). An integrated geological model for the Tennant Creek style Au-Bi-Cu mineralization - Evolution of the Gecko corridor, Tennant Creek Goldfield. Northern Territory Geological Survey, Annual Geoscience Exploration Seminar (AGES), Record of Abstracts, Record 56.

Curtis, S., Wade, C., \& Reid, A. (2018). Sedimentary basin formation associated with a silicic large igneous province: stratigraphy and provenance of the Mesoproterozoic Roopena Basin, Gawler Range Volcanics. Australian Journal of Earth Sciences, 65(4), 447-463. https://doi.org/10.1080/08120099.2018.1460398

Daly, S. J., Fanning, C. M., \& Fairclough, M. C. (1998). Tectonic evolution and exploration potential of the Gawler craton. AGSO Journal of Australian Geology and Geophysics, 17, 145-168.

Davidson, G. J., Paterson, H., Meffre, S., \& Berry, R. F. (2007). Characteristics and origin of the oak dam East Breccia-Hosted, iron oxide $\mathrm{Cu}-\mathrm{U}-(\mathrm{Au})$ Deposit: Olympic Dam region, Gawler Craton, South Australia. Economic Geology, 102(8), 1471-1498. https://doi.org/10.2113/gsecongeo.102.8.1471

de Freitas Toledo, P. I., Moreto, C. P. N., Xavier, R. P., Gao, J., de Matos, J. H. da S. N., \& de Melo, G. H. C. (2019). Multistage evolution of the Neoarchean (ca. 2.7 Ga) Igarapé Cinzento (GT-46) iron oxide copper-gold deposit, Cinzento Shear Zone, Carajás Province, Brazil. Economic Geology, 114(1), 1-34. https://doi.org/10.5382/econgeo.2019.4617

de Haller, A., Corfu, F., Fontboté, L., Schaltegger, U., Barra, F., Chiaradia, M., Frank, M., \& Alvarado, J. Z. (2006). Geology, geochronology, and $\mathrm{Hf}$ and $\mathrm{Pb}$ isotope data of the Raúl-Condestable iron oxidecopper-gold deposit, central coast of Peru. Economic Geology, 101(2), 281-310.

https://doi.org/10.2113/gsecongeo.101.2.281 
de Melo, G. H. C., Monteiro, L. V. S., Xavier, R. P., Moreto, C. P. N., Santiago, E. S. B., Dufrane, S. A., Aires, B., \& Santos, A. F. F. (2017). Temporal evolution of the giant Salobo IOCG deposit, Carajás Province (Brazil): constraints from paragenesis of hydrothermal alteration and $\mathrm{U}-\mathrm{Pb}$ geochronology. Mineralium Deposita, 52(5), 709-732. https://doi.org/10.1007/s00126-0160693-5

Dias, G. S., Macambira, M. B. Dall'Agnol, R., Soares, A. D. v., \& Barros, C. E. M. (1996). Datações de zircões de sill de metagabro: comprovação de idade arqueana da Formação Águas Claras, Carajás, Pará. Simpósio de Geologia Da Amazônia, 5th: Belém, 376-378.

Diella, V., Ferrario, A., \& Girardi, V. A. V. (1995). PGE and PGM in the Luanga mafic-ultramafic intrusion in Serra dos Carajás (Pará State, Brazil). Ore Geology Reviews, 9(6), 445-453. https://doi.org/10.1016/0169-1368(95)00002-J

Donnellan, N. (2013). Chapter 9: Warramunga Province. In M. Ahmad \& T. J. Munson (Eds.), Geology and mineral resources of the Northern Territory (pp. 9:1-9:61). Northern Territory Geological Survey, Special Publication.

Donnellan, N., Hussey, K. J., \& Morrison, R. S. (1995). Flynn 5759, Tennant Creek 5758: Explanatory Notes, 1:100 000 Geological Map Series.

Duncan, R. J., Stein, H. J., Evans, K. A., Hitzman, M. W., Nelson, E. P., \& Kirwin, D. J. (2011). A new geochronological framework for mineralization and alteration in the Selwyn-Mount Dore corridor, Eastern Fold Belt, Mount Isa Inlier, Australia: Genetic implications for iron oxide copper-gold deposits. Economic Geology, 106(2), 169-192. https://doi.org/10.2113/econgeo.106.2.169

Edfelt, Å. (2007). The Tjårrojåkka Apatite-Iron and Cu (-Au ) - Products of One Ore Forming Event. Unpublished $\mathrm{PhD}$ thesis, Luleä University, Sweden.

Edfelt, Å., Sandrin, A., Evins, P., Jeffries, T., Storey, C., Elming, S. Å., \& Martinsson, O. (2006). Stratigraphy and tectonic setting of the host rocks to the Tjårrojåkka Fe-oxide $\mathrm{Cu}-\mathrm{Au}$ deposits, Kiruna area, northern Sweden. Gff, 128(3), 221-232. https://doi.org/10.1080/11035890601283221

Escolme, A., Cooke, D. R., Hunt, J., Berry, R. F., Maas, R., \& Creaser, R. A. (2020). The Productora Cu-AuMo Deposit, Chile: A Mesozoic Magmatic-Hydrothermal Breccia Complex with Both Porphyry and Iron Oxide $\mathrm{Cu}-\mathrm{Au}$ Affinities. Economic Geology, 115(3), 543-580. https://doi.org/10.5382/ECONGE0.4718

Fanning, C. M., Ashley, P. M., Cook, N. D. J., Teale, G. S., \& Conor, C. C. H. (1998). A geochronological perspective of crustal evolution in the Curnamona Province. In G. M. Gibson (Ed.), Broken Hill Exploration Initiative, Record 1998/25 (pp. 30-37). Australian Geological Survey Organisation.

Fareeduddin, G. S., Kirmani, I. R., \& Suresh, C. (2012). Petrology , geochemistry and fluid inclusion studies of $\mathrm{Cu}-\mathrm{Au}$ mineralization in Paleoproterozoic Salumbar-Ghatol Belt, Aravalli Supergroup, Rajasthan. Journal of the Geological Society of India, 80(July), 5-38.

Feio, G. R. L., Dall'Agnol, R., Dantas, E. L., Macambira, M. J. B., Santos, J. O. S., Althoff, F. J., \& Soares, J. E. B. (2013). Archean granitoid magmatism in the Canaã dos Carajás area: Implications for crustal evolution of the Carajás province, Amazonian craton, Brazil. Precambrian Research, 227, 157185. https://doi.org/10.1016/j.precamres.2012.04.007

Fennell, L. M., Folguera, A., Naipauer, M., Gianni, G., Rojas Vera, E. A., Bottesi, G., \& Ramos, V. A. (2017). Cretaceous deformation of the southern Central Andes: synorogenic growth strata in the Neuquén Group (35³0'-37 S). Basin Research, 29, 51-72. https://doi.org/10.1111/bre.12135

Ferris, G. M., Schwarz, M. P., \& Heithersay, P. (2002). The geological framework, distribution and controls of Fe-oxide $\mathrm{Cu}$-Au deposits in the Gawler craton. Part I. Geological and tectonic framework. In T. M. Porter (Ed.), Hydrothermal iron oxide copper-gold and related deposits: $A$ global perspective, Volume 2 (pp. 9-31).

Ferris, G., \& Schwarz, M. (2003). Proterozoic gold province of the central Gawler Craton. MESA Journal, 30(July), 4-12.

Forbes, C. J., Giles, D., Betts, P. G., Weinberg, R., \& Kinny, P. D. (2007). Dating prograde amphibolite and granulite facies metamorphism using in situ monazite U-Pb SHRIMP analysis. Journal of Geology, 115(6), 691-705. https://doi.org/10.1086/521611 
Foster, D. R. W., \& Austin, J. R. (2008). The 1800-1610 Ma stratigraphic and magmatic history of the Eastern Succession, Mount Isa Inlier, and correlations with adjacent Paleoproterozoic terranes. Precambrian Research, 163(1-2), 7-30. https://doi.org/10.1016/j.precamres.2007.08.010

Fraser, G. L., Hussey, K., \& Compston, D. M. (2008). Timing of Palaeoproterozoic Au-Cu-Bi and Wmineralization in the Tennant Creek region, northern Australia: Improved constraints via intercalibration of 40Ar/39Ar and U-Pb ages. Precambrian Research, 164(1-2), 50-65. https://doi.org/10.1016/j.precamres.2008.03.005

Fraser, G. L., Skirrow, R. G., Schmidt-Mumm, A., \& Holm, O. (2007). Mesoproterozoic gold in the central Gawler craton, South Australia: Geology, alteration, fluids, and timing. Economic Geology, 102(8). https://doi.org/10.2113/gsecongeo.102.8.1511

Freeman, H., \& Tomkinson, M. (2010). Geological setting of iron oxide related mineralisation in the southern Mount Woods Domain, South Australia. In T. M. Porter (Ed.), Hydrothermal iron oxide copper-gold and related deposits: A global perspective, Volume 3 (pp. 171-190). PGC Publishing.

Gandhi, S. S., \& Bell, R. T. (1989). Potential for Olympic Dam-type Cu-Au-U-Fe deposits in the Great Bear magmatic zone. In Exploration Overview 1989, Northwest Territories, Part 2, Preliminary reports on geological work in N.W.T. (pp. 32-33). Geological Mapping Division, Indian Affairs and Northern Development, Canada.

Gauthier, L., Hall, G., Stein, H. J., \& Schaltegger, U. (2001). The Osborne deposit, Cloncurry district: A $1595 \mathrm{Ma} \mathrm{Cu}-\mathrm{Au}$ skarn deposit. Contributions of the Economic Geology Research Unit, James Cook University, 59, 58-59.

Gelcich, S., Davis, D. W., \& Spooner, E. T. C. (2005). Testing the apatite-magnetite geochronometer: U$\mathrm{Pb}$ and $40 \mathrm{Ar} / 39 \mathrm{Ar}$ geochronology of plutonic rocks, massive magnetite-apatite tabular bodies, and IOCG mineralization in Northern Chile. Geochimica et Cosmochimica Acta, 69(13), 33673384. https://doi.org/10.1016/j.gca.2004.12.020

Gianni, G. M., Navarrete, C., Echaurren, A., Díaz, M., Butler, K. L., Horton, B. K., Encinas, A., \& Folguera, A. (2020). Northward propagation of Andean genesis: Insights from Early Cretaceous synorogenic deposits in the Aysén-Río Mayo basin. Gondwana Research, 77, 238-259. https://doi.org/10.1016/j.gr.2019.07.014

Gibson, G. M., Meixner, A. J., Withnall, I. W., Korsch, R. J., Hutton, L. J., Jones, L. E. A., Holzschuh, J., Costelloe, R. D., Henson, P. A., \& Saygin, E. (2016). Basin architecture and evolution in the Mount Isa mineral province, northern Australia: Constraints from deep seismic reflection profiling and implications for ore genesis. Ore Geology Reviews, 76, 414-441. https://doi.org/10.1016/j.oregeorev.2015.07.013

Giles, C. W. (1988). Petrogenesis of the Proterozoic Gawler Range Volcanics, South Australia. Precambrian Research, 40-41(C), 407-427. https://doi.org/10.1016/0301-9268(88)90078-2

Giles, D., Betts, P., \& Lister, G. (2002). northeastern Australia. Geological Society of America, 30(9), 823-826.

Girardi, J. D. (2014). Comparison of Mesozoic magmatic evolution and iron oxide (-copper-gold) ('IOCG') mineralization, central Andes and western North America. Unpublished MSc thesis, The University of Arizona.

Grainger, C. J., Groves, D. I., Tallarico, F. H. B., \& Fletcher, I. R. (2008). Metallogenesis of the Carajás Mineral Province, Southern Amazon Craton, Brazil: Varying styles of Archean through Paleoproterozoic to Neoproterozoic base- and precious-metal mineralisation. Ore Geology Reviews, 33(3-4), 451-489. https://doi.org/10.1016/j.oregeorev.2006.10.010

Gregory, C. J., Reid, A. J., Say, P., \& Teale, G. S. (2011). U-Pb geochronology of hydrothermal allanite and titanite and magmatic zircon from the Hillside $\mathrm{Cu}-\mathrm{Au}$ deposit, Yorke Peninsula. In A.J. Reid \& E. A. Jagodzinski (Eds.), PACE geochronology: results of collaborative geochronology projects 2009-10 South Australia, Report Book 2011/00003 (pp. 95-126). Department of Primary Industries and Resources.

Groves, D. I., Bierlein, F. P., Meinert, L. D., \& Hitzman, M. W. (2010). Iron Oxide Copper-Gold (IOCG) Deposits through Earth History: Implications for Origin, Lithospheric Setting, and Distinction from Other Epigenetic Iron Oxide Deposits. Economic Geology, 105, 641-654. 
Hand, M., Reid, A., \& Jagodzinski, L. (2007). Tectonic framework and evolution of the Gawler craton, Southern Australia. Economic Geology, 102(8), 1377-1395.

https://doi.org/10.2113/gsecongeo.102.8.1377

Hawkes, N., Clark, A. H., \& Moody, T. C. (2002). Marcona and Pampa de Pongo: Giant Mesozoic Fe-(Cu, $\mathrm{Au}$ ) deposits in the Peruvian Coastal Belt. In T. M. Porter (Ed.), Hydrothermal iron oxide coppergold and related deposits: A global perspective, Volume 2 (pp. 115-130). PGC Publishing.

Haynes, D. W. (2000). Iron oxide copper (-gold) deposits: their position in the deposit spectrum and modes of origin. In Hydrothermal iron oxide copper-gold and related deposits: A global perspective, Volume 1 (pp. 71-90). Australian Mineral Foundation.

Hennessey, B. T., \& Puritch, E. (2008). A technical report on a mineral resource estimate for the SueDianne deposit, Mazenod Lake area, Northwest Territories, Canada. www.sedar.com

Hildebrand, R. S. (1986). Kiruna-type deposits: their origin and relationship to intermediate subvolcanic plutons in the Great Bear magmatic zone, northwest Canada. Economic Geology, 81(3), 640-659. https://doi.org/10.2113/gsecongeo.81.3.640

Hildebrand, Robert S., Hoffman, P. F., \& Bowring, S. A. (1987). Tectono-magmatic evolution of the 1.9Ga Great Bear magmatic zone, Wopmay orogen, northwestern Canada. Journal of Volcanology and Geothermal Research, 32(1-3), 99-118. https://doi.org/10.1016/0377-0273(87)90039-4

Hildebrand, Robert S., Hoffman, P. F., \& Bowring, S. A. (2010). The Calderian orogeny in Wopmay orogen (1.9 Ga), northwestern Canadian Shield. Bulletin of the Geological Society of America, 122(5-6), 794-814. https://doi.org/10.1130/B26521.1

Hitzman, M. W. (2000). Iron oxide-Cu-Au deposits: what, where, when and why? In T. M. Porter (Ed.), Hydrothermal iron oxide copper-gold and related deposits: A global perspective, Volume 1 (pp. 925). Australian Mineral Foundation.

Huston, D., Cross, A., Skirrow, R., Champion, D., \& Whelan, J. (2020). The Tennant Creek mineral field and Rover fields: Many similarities but some important differences.

Huston, D. L., Bolger, C., \& Cozens, G. (1993). A comparison of mineral deposits at the Gecko and White Devil deposits: implications for ore genesis in the Tennant Creek district, Northern Territory, Australia. Economic Geology, 88(5), 1198-1225. https://doi.org/10.2113/gsecongeo.88.5.1198

Huston, D. L., \& Cozens, G. J. (1994). The geochemistry and alteration of the White Devil porphyry: implications to intrusion timing. Mineralium Deposita, 29(3), 275-287. https://doi.org/10.1007/BF00206871

Jagodzinski, E. A., Reid, A., Crowley, J., McAvaney, S., \& Wade, C. (2016). Precise zircon U-Pb dating of Mesoproterozoic silicic large igneous province: the Gawler Range Volcanics and Benagerie Volcanic Suite, South Australia. Australian Earth Science Convention, Abstracts.

Jagodzinski, L., \& Fricke, C. E. (2010). Compilation of new SHRIMP U-Pb geochronological data for the Southern Curnamona Province, South Australia. South Australia. Department of Primary Industries and Resources, Report Boo.

Johnson, J. P., \& Cross, K. C. (1995). U-Pb geochronological constraints on the genesis of the Olympic Dam Cu-U-Au-Ag deposit, South Australia. Economic Geology, 90, 1046-1063.

Just, J., Schulz, B., de Wall, H., Jourdan, F., \& Pandit, M. K. (2011). Monazite CHIME/EPMA dating of Erinpura granitoid deformation: Implications for Neoproterozoic tectono-thermal evolution of NW India. Gondwana Research, 19(2), 402-412. https://doi.org/10.1016/j.gr.2010.08.002

Kaur, P., Chaudhri, N., Hofmann, A. W., Raczek, I., \& Okrusch, M. (2013). Geochemistry and Sm-Nd geochronology of the metasomatised mafic rocks in the Khetri complex, Rajasthan, NW India: Evidence of an Early Cryogenian metasomatic event in the northern Aravalli orogen. Journal of Asian Earth Sciences, 62, 401-413. https://doi.org/10.1016/j.jseaes.2012.10.023

Kaur, P., Zeh, A., \& Chaudhri, N. (2017). Palaeoproterozoic continental arc magmatism, and Neoproterozoic metamorphism in the Aravalli-Delhi orogenic belt, NW India: New constraints from in situ zircon U-Pb-Hf isotope systematics, monazite dating and whole-rock geochemistry. Journal of Asian Earth Sciences, 136, 68-88. https://doi.org/10.1016/j.jseaes.2017.01.024

Kirschbaum, M. J., \& Hitzman, M. W. (2016). Guelb Moghrein: an unusual, carbonate-hosted iron oxide copper-gold deposit in Mauritania, northwest Africa. Economic Geology, 763-770. 
Knight, J., Joy, S., Lowe, J., Cameron, J., Merrillees, J., Nag, S., Shah, N., Dua, G., \& Jhala, K. (2002). The Khetri copper belt, Rajasthan: iron oxide copper-gold terrane in the Proterozoic of NW India. In T. M. Porter (Ed.), Hydrothermal iron oxide copper-gold and related deposits: A global perspective, Volume 2 (pp. 321-341). PGC Publishing.

Knipping, J. L., Bilenker, L. D., Simon, A. C., Reich, M., Barra, F., Deditius, A. P., Lundstrom, C., Bindeman, I., \& Munizaga, R. (2015). Giant Kiruna-type deposits form by efficient flotation of magmatic magnetite suspensions. Geology, 43(7), 591-594. https://doi.org/10.1130/G36650.1

Kolb, J., Meyer, F. M., Vennemann, T. W., Hoffbauer, R., Gerdes, A., \& Sakellaris, G. A. (2008). Geologic setting of the Guelb Moghrein Fe oxide-Cu-Au-Co mineralisation,Akjoujt area, Mauritania. In N. Ennih \& J.-P. Liégeois (Eds.), The boundaries of the West African craton (pp. 53-75). Geological Society of London, Special Publication.

Kolb, J., Meyer, M., Vennemann, T., Sindern, S., Prantl, S., \& Bottcher, M. E. (2010). Characterisation of the hydrothermal fluids of the Guelb Moghrein iron oxide-Cu-Au-Co deposit, Mauritania: ore mineral chemistry, fluid inclusions and isotope geochemistry. In T. M. Porter (Ed.), Hydrothermal iron oxide copper-gold and related deposits: A global perspective, Volume 4 (pp. 553-572). PGC Publishing.

Kolb, J., \& Petrov, N. (2016). The Guelb Moghrein Cu-Au deposit: Neoarchaean hydrothermal sulfide mineralization in carbonate-facies iron formation. Ore Geology Reviews, 78, 573-577. https://doi.org/10.1016/j.oregeorev.2015.09.003

Köykkä, J., Lahtinen, R., \& Huhma, H. (2019). Provenance evolution of the Paleoproterozoic metasedimentary cover sequences in northern Fennoscandia: Age distribution, geochemistry, and zircon morphology. Precambrian Research, 331(March), 105364. https://doi.org/10.1016/j.precamres.2019.105364

Lahtinen, R., Huhma, H., Lahaye, Y., Jonsson, E., Manninen, T., Lauri, L. S., Bergman, S., Hellström, F., Niiranen, T., \& Nironen, M. (2015). New geochronological and Sm-Nd constraints across the Pajala shear zone of northern Fennoscandia: Reactivation of a Paleoproterozoic suture. Precambrian Research, 256, 102-119. https://doi.org/10.1016/j.precamres.2014.11.006

Lahtinen, Raimo, \& Huhma, H. (2019). A revised geodynamic model for the Lapland-Kola Orogen. Precambrian Research, 330(April), 1-19. https://doi.org/10.1016/j.precamres.2019.04.022

Lahtinen, Raimo, Huhma, H., Sayab, M., Lauri, L. S., \& Hölttä, P. (2018). Age and structural constraints on the tectonic evolution of the Paleoproterozoic Central Lapland Granitoid Complex in the Fennoscandian Shield. Tectonophysics, 745(January), 305-325. https://doi.org/10.1016/j.tecto.2018.08.016

Li, X. C., \& Zhou, M. F. (2018). The nature and origin of hydrothermal REE mineralization in the Sin Quyen deposit, northwestern Vietnam. Economic Geology, 113(3), 645-673. https://doi.org/10.5382/econgeo.2018.4565

Li, X. C., Zhou, M. F., Chen, W. T., Zhao, X. F., \& Tran, M. D. (2018). Uranium-lead dating of hydrothermal zircon and monazite from the Sin Quyen Fe-Cu-REE-Au-(U) deposit, northwestern Vietnam. Mineralium Deposita, 53(3), 399-416. https://doi.org/10.1007/s00126-017-0746-4

Li, X. C., Zhou, M. F., Williams-Jones, A. E., Yang, Y. H., \& Gao, J. F. (2019). Timing and genesis of Cu$\mathrm{Au}$ ) mineralization in the Khetri Copper Belt, northwestern india: Constraints from in situ U-Pb ages and Sm-Nd isotopes of monazite-(Ce). Mineralium Deposita, 54(4), 553-568. https://doi.org/10.1007/s00126-018-0823-3

Li, X., Zhao, X., Zhou, M. F., Chen, W. T., \& Chu, Z. (2015). Fluid inclusion and isotopic constraints on the origin of the Paleoproterozoic Yinachang Fe-Cu-(REE) deposit, Southwest China. Economic Geology, 110(5), 1339-1369. https://doi.org/10.2113/econgeo.110.5.1339

Lin, L., Chen, R., Pang, Z., Chen, H., Xue, J., \& Jia, H. (2020). Sulfide Rb-Sr, Re-Os and in-situ S isotopic constraints on two mineralization events at the large Hongnipo Cu deposit, SW China. Minerals, 10(5), 1-24. https://doi.org/10.3390/min10050414

Liu, L., \& Terry Chen, W. (2019). Geology, mineralization styles and age of ore-hosting rocks of the Proterozoic Longbohe-Sin Quyen Fe-Cu belt: Implications for regional metallogeny. Ore Geology Reviews, 111(July), 103013. https://doi.org/10.1016/j.oregeorev.2019.103013 
Lopez, G. P., Hitzman, M. W., \& Nelson, E. P. (2014). Alteration patterns and structural controls of the El Espino IOCG mining district, Chile. Mineralium Deposita, 49(2), 235-259. https://doi.org/10.1007/s00126-013-0485-0

Machado, N., Lindenmayer, Z., Krogh, T. E., \& Lindenmayer, D. (1991). U-Pb geochronology of Archean magmatism and basement reactivation in the Carajás area, Amazon shield, Brazil. Precambrian Research, 49(3-4), 329-354. https://doi.org/10.1016/0301-9268(91)90040-H

Maidment, D. W., Huston, D. L., Donnellan, N., \& Lambeck, A. (2013). Constraints on the timing of the Tennant Event and associated $\mathrm{Au}-\mathrm{Cu}$ - Bi mineralisation in the Tennant Region, Northern Territory. Precambrian Research, 237, 51-63. https://doi.org/10.1016/j.precamres.2013.07.020

Maksaev, V., \& Zentilli, M. (2002). Chilean strata-bound Cu- (Ag) deposits: An overview. In T. M. Porter (Ed.), Hydrothermal iron oxide copper-gold and related deposits: A global perspective, Volume 2 (pp. 185-205). PGC Publishing.

Mark, G. (2001). Nd isotope and petrogenetic constraints for the origin of the Mount Angelay igneous complex: Implications for the origin of intrusions in the Cloncurry district, NE Australia. Precambrian Research, 105(1), 17-35. https://doi.org/10.1016/S0301-9268(00)00101-7

Mark, Geordie, Foster, D. R. W., Pollard, P. J., Williams, P. J., Tolman, J., Darvall, M., \& Blake, K. L. (2004). Stable isotope evidence for magmatic fluid input during large-scale $\mathrm{Na}$-Ca alteration in the Cloncurry Fe oxide Cu - Au district, NW Queensland, Australia. https://doi.org/10.1111/j.1365-3121.2004.00527.x

Mark, Geordie, Oliver, N. H. S., \& Williams, P. J. (2006). Mineralogical and chemical evolution of the Ernest Henry Fe oxide-Cu-Au ore system, Cloncurry district, northwest Queensland, Australia. Mineralium Deposita, 40(8), 769-801. https://doi.org/10.1007/s00126-005-0009-7

Marschik, R., \& Fontboté, L. (2001). The Candelaria-Punta del Cobre iron oxide Cu-Au (-Zn-Ag) deposits, Chile. Economic Geology, 96(8), 1799-1826. https://doi.org/10.2113/gsecongeo.96.8.1799

Marschik, R., Mathur, R., Ruiz, J., Leveille, R. A., \& de Almeida, A. J. (2005). Late Archean Cu-Au-Mo mineralization at Gameleira and Serra Verde, Carajàs Mineral Province, Brazil: Constraints from Re-Os molybdenite ages. Mineralium Deposita, 39(8), 983-991. https://doi.org/10.1007/s00126-004-0450-z

Martinsson, O., Billström, K., Broman, C., Weihed, P., \& Wanhainen, C. (2016a). Metallogeny of the Northern Norrbotten Ore Province, Northern Fennoscandian Shield with emphasis on IOCG and apatite-iron ore deposits. Ore Geology Reviews, 78, 447-492.

https://doi.org/10.1016/j.oregeorev.2016.02.011

Martinsson, O., Billström, K., Broman, C., Weihed, P., \& Wanhainen, C. (2016b). Metallogeny of the Northern Norrbotten Ore Province, Northern Fennoscandian Shield with emphasis on IOCG and apatite-iron ore deposits. Ore Geology Reviews, 78, 447-492. https://doi.org/10.1016/j.oregeorev.2016.02.011

Mathur, R., Marschik, R., Ruiz, J., Munizaga, F., Leveille, R. A., \& Martin, W. (2002). Age of mineralization of the Candelaria Fe oxide $\mathrm{Cu}-\mathrm{Au}$ deposit and the origin of the Chilean Iron Belt, based on Re-Os isotopes. Economic Geology, 97, 59-71.

McInnes, B. I. A., Keays, R. R., Lambert, D. D., Hellstrom, J., \& Allwood, J. S. (2008). Re-Os geochronology and isotope systematics of the Tanami, Tennant Creek and Olympic Dam Cu-Au deposits. Australian Journal of Earth Sciences, 55(6-7), 967-981. https://doi.org/10.1080/08120090802097443

McKenzie, N. R., Hughes, N. C., Myrow, P. M., Banerjee, D. M., Deb, M., \& Planavsky, N. J. (2013). New age constraints for the Proterozoic Aravalli-Delhi successions of India and their implications. Precambrian Research, 238, 120-128. https://doi.org/10.1016/j.precamres.2013.10.006

McLean, R. N. (2002). The Sin Quyen iron oxide-copper-gold-rare earth oxide mineralisation of north Vietnam. In T. M. Porter (Ed.), Hydrothermal iron oxide copper-gold and related deposits: A global perspective, Volume 2 (pp. 293-301). PGC Publishing.

McPhie, J., Ehrig, K. J., Kamenetsky, M. B., Crowley, J. L., \& Kamenetsky, V. S. (2020). Geology of the Acropolis prospect, South Australia, constrained by high-precision CA-TIMS ages. Australian Journal of Earth Sciences, 67(5), 699-716. https://doi.org/10.1080/08120099.2020.1717617 
Meyer, M. F., Kolb, J., Sakellaris, G. A., \& Gerdes, A. (2006). New ages from the Mauritanides Belt: Recognition of Archean IOCG mineralization at Guelb Moghrein, Mauritania. Terra Nova, 18(5), 345-352. https://doi.org/10.1111/j.1365-3121.2006.00698.x

Monteiro, L. V. S., Xavier, R. P., Carvalho, E. R., Hitzman, M. W., Johnson, C. A., Souza Filho, C. R., \& Torresi, I. (2008). Spatial and temporal zoning of hydrothermal alteration and mineralization in the Sossego iron oxide-copper-gold deposit, Carajás Mineral Province, Brazil: Paragenesis and stable isotope constraints. In Mineralium Deposita (Vol. 43, Issue 2). https://doi.org/10.1007/s00126-006-0121-3

Montreuil, J. F., Corriveau, L., \& Davis, W. J. (2016). Tectonomagmatic evolution of the southern Great Bear magmatic zone (Northwest Territories, Canada): Implications for the genesis of iron oxidealkali-altered hydrothermal systems. Economic Geology, 111(8), 2111-2138. https://doi.org/10.2113/econgeo.111.8.2111

Moreto, C. P.N., Monteiro, L. V. S., Xavier, R. P., Creaser, R. A., DuFrane, S. A., Tassinari, C. C. G., Sato, K., Kemp, A. I. S., \& Amaral, W. S. (2015). Neoarchean and paleoproterozoic iron oxide-copper-gold events at the sossego deposit, Carajás Province, Brazil: Re-Os and U-Pb geochronological evidence. Economic Geology, 110(3), 809-835. https://doi.org/10.2113/econgeo.110.3.809

Moreto, Carolina Penteado Natividade, Monteiro, L. V. S., Xavier, R. P., Amaral, W. S., dos Santos, T. J. S., Juliani, C., \& de Filho, C. R. S. (2011). Mesoarchean (3.0 and 2.86 Ga) host rocks of the iron oxide-Cu-Au Bacaba deposit, Carajás Mineral Province: U-Pb geochronology and metallogenetic implications. Mineralium Deposita, 46(7), 789-811. https://doi.org/10.1007/s00126-011-03529

Moreto, Carolina P.N., Monteiro, L. V. S., Xavier, R. P., Creaser, R. A., DuFrane, S. A., Melo, G. H. C., Delinardo da Silva, M. A., Tassinari, C. C. G., \& Sato, K. (2015). Timing of multiple hydrothermal events in the iron oxide-copper-gold deposits of the Southern Copper Belt, Carajás Province, Brazil. Mineralium Deposita, 50(5), 517-546. https://doi.org/10.1007/s00126-014-0549-9

Morrissey, L. J., \& Tomkins, A. G. (2020). Evaporite-bearing orogenic belts produce ligand-rich and diverse metamorphic fluids. Geochimica et Cosmochimica Acta, 275, 163-187. https://doi.org/10.1016/j.gca.2020.02.017

Mukherjee, R., Venkatesh, A. S., \& Fareeduddin, G. S. (2019). Geochemical characterization of mineralized albitite from Paleoproterozoic Bhukia IOCG - IOA deposit of Aravalli - Delhi Fold Belt , Rajasthan, western India : Genetic linkage to the gold ( $\pm \mathrm{Cu} \pm \mathrm{U}$ ) mineralization. Geological Journal, October 2018, 4203-4225. https://doi.org/10.1002/gj.3669

Mukhopadhyay, S., Kumar, V., \& Sangwan, M. (2019). Sediment Hosted Stratiform Copper (SSC) Mineralization in Bhudoli-Basari Area, North Delhi Fold Belt, Mesoproterozoic Delhi Supergroup, Rajasthan. Journal of the Geological Society of India, 93(6), 663-674. https://doi.org/10.1007/s12594-019-1245-2

Mumin, A. H., Corriveau, L., Somarin, A. K., \& Ootes, L. (2007). Iron oxide copper-gold-type polymetallic mineralization in the Contact Lake belt, Great Bear magmatic zone, Northwest Territories, Canada. Exploration and Mining Geology, 16, 187-208.

Mumin, A. H., Somarin, A. K., Jones, B., Corriveau, L., Ootes, L., \& Camier, J. (2010). The IOCGporphyry-epithermal continuum of deposit types in the Great Bear magmatic zone, Northwest Territories, Canada. In Louise Corriveau \& A. H. Mumin (Eds.), Exploring for iron oxide coppergold deposits: Canada and global analogues (pp. 59-78). Geological Association of Canada, Short Course Notes, Volume 20.

Nguyen, P. T., Booth, S. A., Both, R. A., \& James, P. R. (1989). The White Devil gold deposit, Tennant Creek, Northern Territory, Australia. Economic Geology Monograph, 6, 180-192.

Nicolson, B., Reid, A., McAvaney, S., Keeling, J., Fraser, G., Vasconcelos, P., \& Department of State Development. (2017). A Mesoproterozoic advanced argillic alteration system: 40Ar/39Ar thermochronology from Nankivel Hill, Gawler Craton. Report Book 2017/00011, 39.

Oliver, N. H. S., Butera, K. M., Rubenach, M. J., Marshall, L. J., Cleverley, J. S., Mark, G., Tullemans, F., \& Esser, D. (2008). The protracted hydrothermal evolution of the Mount Isa Eastern Succession: A review and tectonic implications. Precambrian Research, 163(1-2), 108-130.

https://doi.org/10.1016/j.precamres.2007.08.019 
Oliver, N. H. S., Cleverley, J. S., Mark, G., Pollard, P. J., Fu, B., Marshall, L. J., Rubenach, M. J., Williams, P. J., \& Baker, T. (2004). Modeling the role of sodic alteration in the genesis of iron oxide-coppergold deposits, Eastern Mount Isa Block, Australia. Economic Geology, 99(6), 1145-1176. https://doi.org/10.2113/gsecongeo.99.6.1145

Oliveros, V., Tristá-Aguilera, D., Féraud, G., Morata, D., Aguirre, L., Kojima, S., \& Ferraris, F. (2008). Time relationships between volcanism-plutonism-alteration-mineralization in $\mathrm{Cu}$-stratabound ore deposits from the Michilla mining district, northern Chile: A 40Ar/39Ar geochronological approach. Mineralium Deposita, 43(1), 61-78. https://doi.org/10.1007/s00126-007-0147-1

Olszewski, W. J., Wirth, K. R., Gibbs, A. K., \& Gaudette, H. E. (1989). The age, origin, and tectonics of the Grão Pará Group and associated rocks, Serra dos Carajás, Brazil: Archean continental volcanism and rifting. Precambrian Research, 42(3-4), 229-254. https://doi.org/10.1016/03019268(89)90013-2

Ootes, L., Goff, S., Jackson, V. A., Gleeson, S. A., Creaser, R. A., Samson, I. M., Evensen, N., Corriveau, L., \& Mumin, A. H. (2010). Timing and thermochemical constraints on multi-element mineralisation at the Nori/RA Cu-Mo-U prospect, Great Bear magmatic zone, Northwest Territories, Canada. Mineralium Deposita, 45(6), 549-566. https://doi.org/10.1007/s00126-010-0291-x

Ootes, L., Snyder, D., Davis, W. J., Acosta-Góngora, P., Corriveau, L., Mumin, A. H., Gleeson, S. A., Samson, I. M., Montreuil, J. F., Potter, E., \& Jackson, V. A. (2017). A Paleoproterozoic Andean-type iron oxide copper-gold environment, the Great Bear magmatic zone, Northwest Canada. Ore Geology Reviews, 81, 123-139. https://doi.org/10.1016/j.oregeorev.2016.09.024

Oyarzun, R., Rodríguez, M., Pincheira, M., Doblas, M., \& Helle, S. (1999). The Candelaria (Cu-Fe-Au) and Punta del Cobre (Cu-Fe) deposits (Copiapo, Chile): A case for extension-related granitoid emplacement and mineralization processes? Mineralium Deposita, 34(8), 799-801. https://doi.org/10.1007/s001260050241

Oyarzun, Roberto, Oyarzún, J., Ménard, J. J., \& Lillo, J. (2003). The Cretaceous iron belt of northern Chile: Role of oceanic plates, a superplume event, and a major shear zone. Mineralium Deposita, 38(5), 640-646. https://doi.org/10.1007/s00126-003-0359-y

Ozha, M. K., Mishra, B., Hazarika, P., Jeyagopal, A. v., \& Yadav, G. S. (2016). EPMA monazite geochronology of the basement and supracrustal rocks within the Pur-Banera basin , Rajasthan: Evidence of Columbia breakup in Northwestern India. JOURNAL OF ASIAN EARTH SCIENCES, 117, 284-303. https://doi.org/10.1016/j.jseaes.2015.12.016

Page, R. W., Stevens, B. P. J., \& Gibson, G. M. (2005). Geochronology of the sequence hosting the Broken Hill Pb-Zn-Ag orebody, Australia. Economic Geology, 100(4), 633-661. https://doi.org/10.2113/gsecongeo.100.4.633

Perkins, C., \& Wyborn, L. A. I. (1998). Age of Cu-Au mineralisation, Cloncurry district, eastern Mt Isa Inlier, Queensland, as determined by $40 \mathrm{Ar} / 39 \mathrm{Ar}$ dating. Australian Journal of Earth Sciences, 45(2), 233-246. https://doi.org/10.1080/08120099808728384

Perring, C. S., Pollard, P. J., Dong, G., Nunn, A. J., \& Blake, K. L. (2000). The Lightning Creek Sill complex, cloncurry district, Northwest Queensland: A source of fluids for Fe Oxide $\mathrm{Cu}-\mathrm{Au}$ mineralization and sodic-calcic alteration. Economic Geology, 95(5), 1067-1089. https://doi.org/10.2113/gsecongeo.95.5.1067

Pestilho, A. L. S., Monteiro, L. V. S., Melo, G. H. C. de, Moreto, C. P. N., Juliani, C., Fallick, A. E., \& Xavier, R. P. (2020). Stable isotopes and fluid inclusion constraints on the fluid evolution in the Bacaba and Castanha iron oxide-copper-gold deposits, Carajás Mineral Province, Brazil. Ore Geology Reviews, 126(April 2019), 103738. https://doi.org/10.1016/j.oregeorev.2020.103738

Pidgeon, R. T., MacAmbira, M. J. B., \& Lafon, J. M. (2000). Th-U-Pb isotopic systems and internal structures of complex zircons from an enderbite from the Pium Complex, Carajas Province, Brazil: Evidence for the ages of granulite facies metamorphism and the protolith of the enderbite. Chemical Geology, 166(1-2), 159-171. https://doi.org/10.1016/S00092541(99)00190-4

Pollard, P. J., Taylor, R. G., Peters, L., Matos, F., Freitas, C., Saboia, L., \& Huhn, S. (2019). 40 Ar- 39 Ar dating of Archean iron oxide $\mathrm{Cu}-\mathrm{Au}$ and Paleoproterozoic granite-related $\mathrm{Cu}-\mathrm{Au}$ deposits in the Carajás Mineral Province, Brazil: implications for genetic models. Mineralium Deposita, 54(3), 329-346. https://doi.org/10.1007/s00126-018-0809-1 
Priyam Sharma, J., Ranjan Sahoo, P., Mahanta, H., Venkatesh, A. S., Babu, E. V. S. S. K., \& John, M. M. (2020). Constraints on the genesis of the Proterozoic bornite dominated copper deposit from Nim ka Thana, western India: An IOCG perspective. Ore Geology Reviews, 118(May 2019), 103338. https://doi.org/10.1016/j.oregeorev.2020.103338

Raab, A. K. (2001). Geology of the Cerro Negro Norte Fe-oxide (Cu-Au) district, Coastal Cordillera, northern Chile.

Rattenbury, M. S. (1992). Stratigraphic and structural controls on ironstone mineralization in the Tennant Creek goldfield, Northern Territory, Australia. Australian Journal of Earth Sciences, 39(5), 591-602. https://doi.org/10.1080/08120099208728052

Rattenbury, M. S. (1994). A linked fold-thrust model for the deformation of the Tennant Creek goldfield, northern Australia. Mineralium Deposita, 29(3), 301-308. https://doi.org/10.1007/BF00206873

Ray, G. E., \& Dick, L. A. (2002). The Productora prospect in north-central Chile: An example of an intrusion-related, Candelaria type Fe-Cu-Au hydrothermal system. In T. M. Porter (Ed.), Hydrothermal iron oxide copper-gold and related deposits: A global perspective, Volume 2 (pp. 131-151). PGC Publishing.

Raymond, O. L., Fletcher, I., \& McNaughton, N. J. (2002). Copper-gold mineral systems in the southeast Gawler Craton - Another Mt Isa Eastern Succession? 16th Australian Geological Convention, Abstracts.

Reich, M., Simon, A. C., Deditius, A., Barra, F., Chryssoulis, S., Lagas, G., Tardani, D., Knipping, J., Bilenker, L., Sánchez-alfaro, P., Roberts, M. P., \& Munizaga, R. (2016). SCIENTIFIC COMMUNICATIONS. 743-761.

Reid, A. J., Fricke, C., \& Cowley, W. M. (2009). Extent of the low-grade Archaean Devils Playground Volcanics in the north-eastern Gawler Craton: Evidence from recent PACE drilling. MESA Journal, 54, 9-19.

Reid, A., Smith, R. N., Baker, T., Jagodzinski, E. A., Selby, D., Gregory, C. J., \& Skirrow, R. G. (2013). ReOs dating of molybdenite within hematite breccias from the vulcan $\mathrm{Cu}-\mathrm{Au}$ prospect, olympic $\mathrm{Cu}-$ Au province, South Australia. Economic Geology, 108(4). https://doi.org/10.2113/econgeo.108.4.883

Reid, Anthony J. (2019). The Olympic Cu-Au Province, Gawler Craton: A review of the lithospheric architecture, alteration systems, cover successions and prospectivity. Minerals, 1-37.

Reid, Anthony J., \& Fabris, A. (2015). Influence of preexisting low metamorphic grade sedimentary successions on the distribution of iron oxide copper-gold mineralization in the Olympic $\mathrm{Cu}-\mathrm{Au}$ Province, Gawler Craton. Economic Geology, 110(8), 2147-2157. https://doi.org/10.2113/econgeo.110.8.2147

Requia, K., Stein, H., Fontboté, L., \& Chiaradia, M. (2003). Re-Os and Pb-Pb geochronology of the Archean Salobo iron oxide copper-gold deposit, Carajás mineral province, northern Brazil. Mineralium Deposita, 38(6), 727-738. https://doi.org/10.1007/s00126-003-0364-1

Richards, J. P., Lopez, G. P., Zhu, J. J., Creaser, R. A., Locock, A. J., \& Mumin, A. H. (2017). Contrasting tectonic settings and sulfur contents of magmas associated with cretaceous porphyry $\mathrm{Cu} \pm \mathrm{Mo} \pm$ $\mathrm{Au}$ and intrusion-related iron oxide $\mathrm{Cu}-\mathrm{Au}$ deposits in northern Chile. Economic Geology, 112(2), 295-318. https://doi.org/10.2113/econgeo.112.2.295

Rojas, P. A., Barra, F., Reich, M., Deditius, A., Simon, A., Uribe, F., Romero, R., \& Rojo, M. (2018a). A genetic link between magnetite mineralization and diorite intrusion at the El Romeral iron oxide-apatite deposit, northern Chile. Mineralium Deposita, 53(7), 947-966. https://doi.org/10.1007/s00126-017-0777-x

Rojas, P. A., Barra, F., Reich, M., Deditius, A., Simon, A., Uribe, F., Romero, R., \& Rojo, M. (2018b). A genetic link between magnetite mineralization and diorite intrusion at the El Romeral iron oxide-apatite deposit, northern Chile. Mineralium Deposita, 53(7), 947-966. https://doi.org/10.1007/s00126-017-0777-x

Romer, R. L., Martinsson, O., \& Perdahl, J.-A. (1994). Geochronology of the Kiruna iron ores and hydrothermal alterations. Economic Geology, 89, 1249-1261. 
Ronzê, P. C., Soares, A. D. v., dos Santos, M. G. S., \& Barreira, C. F. (2000). Alemão copper-gold (U-REE) deposit, Carajás, Brazil. In T. M. Porter (Ed.), Hydrothermal iron oxide copper-gold and related deposits: A global perspective, Volume 1 (pp. 191-202). Australian Mineral Foundation.

Rotherham, J. F. (1997). A metasomatic origin for the iron-oxide Au-Cu Starra orebodies, Eastern Fold Belt, Mount Isa Inlier. Mineralium Deposita, 32(3), 205-218. https://doi.org/10.1007/s001260050086

Rubenach, M. J., Foster, D. R. W., Evins, P. M., Blake, K. L., \& Fanning, C. M. (2008). Age constraints on the tectonothermal evolution of the Selwyn Zone, Eastern Fold Belt, Mount Isa Inlier. Precambrian Research, 163(1-2), 81-107. https://doi.org/10.1016/j.precamres.2007.08.014

Rubenach, M. J., \& Lewthwaite, K. A. (2002). Metasomatic albitites and related biotite-rich schists from a low-pressure polymetamorphic terrane, Snake Creek Anticline, Mount Isa Inlier, NorthEastern Australia: Microstructures and P-T-d paths. Journal of Metamorphic Geology, 20(1), 191202. https://doi.org/10.1046/j.0263-4929.2001.00348.x

Sarlus, Z., Andersson, U. B., Bauer, T. E., Wanhainen, C., Martinsson, O., Nordin, R., \& Andersson, J. B. H. (2018). Timing of plutonism in the Gällivare area: Implications for Proterozoic crustal development in the northern Norrbotten ore district, Sweden. Geological Magazine, 155(6), 1351-1376. https://doi.org/10.1017/S0016756817000280

Schofield, A. (2010). Investigation of drill holes in the vicinity of the 08GA-C1 seismic line in the Curnamona Province, South Australia Investigation of drill holes in the vicinity of the 08GA-C1 seismic line in the Curnamona Province, South Australia. Geoscience Australia, Record 201.

Schutesky, M. E., \& de Oliveira, C. G. (2020). From the roots to the roof: An integrated model for the Neoarchean Carajás IOCG System, Brazil. Ore Geology Reviews, 127(October), 103833. https://doi.org/10.1016/j.oregeorev.2020.103833

Scott, D. L., Rawlings, D. J., Page, R. W., Tarlowski, C. Z., Idnurm, M., Jackson, M. J., \& Southgate, P. N. (2000). Basement framework and geodynamic evolution of the Palaeoproterozoic superbasins of north-central Australia: An integrated review of geochemical, geochronological and geophysical data. Australian Journal of Earth Sciences, 47(3), 341-380. https://doi.org/10.1046/j.1440-0952.2000.00793.x

Seymour, N. M., Singleton, J. S., Mavor, S. P., Gomila, R., Stockli, D. F., Heuser, G., \& Arancibia, G. (2020). The Relationship Between Magmatism and Deformation Along the Intra-arc Strike-Slip Atacama Fault System, Northern Chile. Tectonics, 39(3). https://doi.org/10.1029/2019TC005702

Sillitoe, R. H. (2003). Iron oxide-copper-gold deposits: An Andean view. Mineralium Deposita, 38(7), 787-812. https://doi.org/10.1007/s00126-003-0379-7

Simon, A. C., Knipping, Reich, M., Barra, F., Deditius, A. P., Bilenker, L. D., \& Childress, T. (2018). Kiruna-type iron oxide-apatite (IOA) and iron oxide copper-gold (IOCG) deposits form by a combination of igneous and magmatic-hydrothermal processes: evidence from the Chilean Iron Belt. Society of Economic Geologists Special Publication, No. 21, 89-114.

Skirrow, R. G. (1993). The genesis of gold-copper-bismuth deposits, Tennant Creek, Northern Territory. Unpublished PhD thesis, Australian National University.

Skirrow, R. G. (2000). Gold-copper-bismuth deposits of the Tennant Creek district, Australia: a reappraisal of diverse high-grade systems. In T. M. Porter (Ed.), Hydrothermal iron oxide coppergold and related deposits: A global perspective, Volume 1 (pp. 149-160). Australian Mineral Foundation.

Skirrow, R. G. (2010). “Hematite-group” IOCG \pm U ore systems: tectonic settings, hydrothermal characteristics, and $\mathrm{Cu}-\mathrm{Au}$ and $\mathrm{U}$ mineralizing processes. In L. Corriveau \& H. Mumin (Eds.), Exploring for iron oxide copper-gold deposits: Canada and global analogues (pp. 39-58). Geological Association of Canada, Short Course Notes, Volume 20.

Skirrow, R. G., Ashley, P. M., McNaughton, M. J., \& Suzuki, K. (2000). Time-space framework of Cu-Au(Mo) and regional alteration systems in the Curnamona Province. AGSO Record 2000/10, 83-86.

Skirrow, R. G., Bastrakov, E. N., Barovich, K., Fraser, G. L., Creaser, R. A., Fanning, C. M., Raymond, O. L., \& Davidson, G. J. (2007). Timing of iron oxide $\mathrm{Cu}-\mathrm{Au}-(\mathrm{U})$ hydrothermal activity and $\mathrm{Nd}$ isotope constraints on metal sources in the Gawler craton, South Australia. Economic Geology, 102(8). https://doi.org/10.2113/gsecongeo.102.8.1441 
Skirrow, R. G., Bastrakov, E. N., Davidson, G. J., Raymond, O. L., \& Heithersay, P. (2002). The geological framework, distribution and controls of Fe-oxide $\mathrm{Cu}$-Au mineralisation in the Gawler craton, South Australia: Part II - Alteration and mineralisation. In T. M. Porter (Ed.), Hydrothermal iron oxide copper-gold and related deposits: A global perspective, Volume 2 (pp. 33-47). PGC Publishing.

Skirrow, R. G., Cross, A. J., Lecomte, A., \& Mercadier, J. (2019). A shear-hosted Au-Cu-Bi metallogenic event at $\sim 1660 \mathrm{Ma}$ in the Tennant Creek goldfield (northern Australia) defined by in-situ monazite U-Pb-Th dating. Precambrian Research, 332. https://doi.org/10.1016/j.precamres.2019.105402

Skirrow, R. G., van der Wielen, S. E., Champion, D. C., Czarnota, K., \& Thiel, S. (2018). Lithospheric Architecture and Mantle Metasomatism Linked to Iron Oxide $\mathrm{Cu}$-Au Ore Formation: Multidisciplinary Evidence from the Olympic Dam Region, South Australia. Geochemistry, Geophysics, Geosystems, 19(8). https://doi.org/10.1029/2018GC007561

Skirrow, R. G., \& Walshe, J. L. (2002). Reduced and oxidized Au-Cu-Bi iron oxide deposits of the Tennant Creek Inlier, Australia: An integrated geologic and chemical model. Economic Geology, 97(6). https://doi.org/10.2113/gsecongeo.97.6.1167

Slack, J. F., Corriveau, L., \& Hitzman, M. W. (2016). A special issue devoted to proterozoic iron oxideapatite $( \pm$ REE) and iron oxide copper-gold and affiliated deposits of Southeast Missouri, USA, and the great bear Magmatic Zone, Northwest Territories, Canada. Economic Geology, 111(8), 1803-1814. https://doi.org/10.2113/econgeo.111.8.1803

Smith, J. (2001). Summary of Results Joint NTGS - AGSO Age Determination Program. Darwin, November.

Smith, M., Coppard, J., Herrington, R., \& Stein, H. (2007). The geology of the Rakkurijärvi Cu-(Au) prospect, Norrbotten: A new iron oxide-copper-gold deposit in north Sweden. Economic Geology, 102(3), 393-414. https://doi.org/10.2113/gsecongeo.102.3.393

Smith, M. P., Coppard, J., \& Herrington, R. (2010). The geology of the Rakurijarvi copper-prospect, Norbotten County, Sweden. In T. M. Porter (Ed.), Hydrothermal iron oxide copper-gold and related deposits: A global perspective, Volume 4 (pp. 427-440). PGC Publishing.

Southgate, P. N., Bradshaw, B. E., Domagala, J., Jackson, M. J., Idnurm, M., Krassay, A. A., Page, R. W., Sami, T. T., Scott, D. L., Lindsay, J. F., McConachy, B. A., \& Tarlowski, C. (2000).

Chronostratigraphic basin framework for Palaeoproterozoic rocks (1730-1575 Ma) in northern Australia and implications for base-metal mineralisation. Australian Journal of Earth Sciences, 47, 461-483.

Southgate, P. N., Neumann, N. L., \& Gibson, G. M. (2013). Depositional systems in the Mt Isa Inlier from $1800 \mathrm{Ma}$ to $1640 \mathrm{Ma}$ : Implications for $\mathrm{Zn}-\mathrm{Pb}-\mathrm{Ag}$ mineralisation. Australian Journal of Earth Sciences, 60(2), 157-173. https://doi.org/10.1080/08120099.2013.758176

Souza, L. H., \& Vieira, E. A. P. (2000). Salobo 3 Alpha deposit: geology and mineralisation. In T. M. Porter (Ed.), Hydrothermal iron oxide copper-gold and related deposits: A global perspective, Volume 1 (pp. 213-224). Australian Mineral Foundation.

Tallarico, F. H. B. (2003). O cinturão cupro-aurifero de Carajas, Brasil. Unpublished PhD thesis, Universidade Estadual de Campinas.

Tallarico, Fernando H.B., Figueiredo, B. R., Groves, D. I., Kositcin, N., McNaughton, N. J., Fletcher, I. R., \& Rego, J. L. (2005). Geology and SHRIMP U-Pb geochronology of the Igarapé Bahia deposit, Carajás copper-gold belt, Brazil: An Archean (2.57 Ga) example of Iron-Oxide $\mathrm{Cu}-\mathrm{Au}$-(U-REE) mineralization. Economic Geology, 100(1), 7-28. https://doi.org/10.2113/100.1.0007

Tallarico, Fernando Henrique Bucco, McNaughton, N. J., Groves, D. I., Fletcher, I. R., Figueiredo, B. R., Carvalho, J. B., Rego, J. L., \& Nunes, A. R. (2004). Geological and SHRIMP II U-Pb constraints on the age and origin of the Breves $\mathrm{Cu}-\mathrm{Au}-(\mathrm{W}-\mathrm{Bi}-\mathrm{Sn})$ deposit, Carajás, Brazil. Mineralium Deposita, 39(1), 68-86. https://doi.org/10.1007/s00126-003-0383-y

Teale, G. S., \& Fanning, C. M. (2000). The timing of $\mathrm{Cu}-\mathrm{Au}$ mineralisation in the Curnamona Province. AGSO Record 2000/10, 98-100.

Tiddy, C. J., \& Giles, D. (2020). Suprasubduction zone model for metal endowment at 1.60-1.57 Ga in eastern Australia. Ore Geology Reviews, 122(March), 103483.

https://doi.org/10.1016/j.oregeorev.2020.103483 
Tornos, F., Velasco, F., Barra, F., \& Morata, D. (2010). The Tropezón Cu-Mo-(Au) deposit, Northern Chile: the missing link between IOCG and porphyry copper systems? Mineralium Deposita, 45, 313-321. https://doi.org/DOI 10.1007/s00126-010-0277-8

Trendall, A. F., Basei, M. A. S., de Laeter, J. R., \& Nelson, D. R. (1998). SHRIMP zircon U-Pb constraints on the age of the Carajas formation, Grao Para Group, Amazon Craton. Journal of South American Earth Sciences, 11(3), 265-277. https://doi.org/10.1016/S0895-9811(98)00015-7

Tristá-Aguilera, D., Barra, F., Ruiz, J., Morata, D., Talavera-Mendoza, O., Kojima, S., \& Ferraris, F. (2006). Re-Os isotope systematics for the Lince-Estefanía deposit: Constraints on the timing and source of copper mineralization in a stratabound copper deposit, Coastal Cordillera of Northern Chile. Mineralium Deposita, 41(1), 99-105. https://doi.org/10.1007/s00126-006-0048-8

Trunfull, E. F., Hagemann, S. G., Xavier, R. P., \& Moreto, C. P. N. (2020). Critical assessment of geochronological data from the Carajás Mineral Province, Brazil: Implications for metallogeny and tectonic evolution. Ore Geology Reviews, 121(March), 103556. https://doi.org/10.1016/j.oregeorev.2020.103556

Veloso, E., Cembrano, J., Arancibia, G., Heuser, G., Neira, S., Siña, A., Garrido, I., Vermeesch, P., \& Selby, D. (2017). Tectono-metallogenetic evolution of the Fe-Cu deposit of Dominga, northern Chile. Mineralium Deposita, 52(4), 595-620. https://doi.org/10.1007/s00126-016-0682-8

Vila, T., Lindsay, N., \& Zamora, R. (1996). Geology of the Mantoverde copper deposit, northern Chile: A specularite-rich hydrothermal-tectonic breccia related to the Atacama fault zone. Economic Geology Special Publication 5, 157-170.

Wade, C. E., Reid, A. J., Wingate, M. T. D., Jagodzinski, E. A., \& Barovich, K. (2012). Geochemistry and geochronology of the c. 1585Ma Benagerie Volcanic Suite, southern Australia: Relationship to the Gawler Range Volcanics and implications for the petrogenesis of a Mesoproterozoic silicic large igneous province. Precambrian Research, 206-207, 17-35. https://doi.org/10.1016/j.precamres.2012.02.020

Walters, S., \& Bailey, A. (1998). Geology and mineralization of the Cannington Ag-Pb-Zn deposit: An example of Broken Hill-type mineralization in the Eastern Succession, Mount Isa Inlier, Australia. Economic Geology, 93, 1307-1329.

Wanhainen, C., Billström, K., Martinsson, O., Stein, H., \& Nordin, R. (2005). 160 Ma of magmatic/hydrothermal and metamorphic activity in the Gällivare area: Re-Os dating of molybdenite and $\mathrm{U}-\mathrm{Pb}$ dating of titanite from the Aitik $\mathrm{Cu}-\mathrm{Au}-\mathrm{Ag}$ deposit, northern Sweden. Mineralium Deposita, 40(4), 435-447. https://doi.org/10.1007/s00126-005-0006-x

Wanhainen, C., \& Martinsson, O. (2010). The hybrid character of the Aitik deposit, Norbotten, Sweden: a porphyry $\mathrm{Cu}-\mathrm{Au}-\mathrm{Ag}(-\mathrm{Mo})$ system overprinted by iron-oxide $\mathrm{Cu}-\mathrm{Au}$ hydrothermal fluids. In T. M. Porter (Ed.), Hydrothermal iron oxide copper-gold and related deposits: A global perspective, Volume 4 (pp. 415-426). PGC Publishing.

Wedekind, M. R., Large, R. R., \& Williams, B. T. (1989). Controls on high-grade gold mineralization at Tennant Creek, Northern Territory, Australia (pp. 168-179). Economic Geology, Monograph 6.

Weihed, P., Arndt, N., Billström, K., Duchesne, J. C., Eilu, P., Martinsson, O., Papunen, H., \& Lahtinen, R. (2005). 8: Precambrian geodynamics and ore formation: The Fennoscandian Shield. Ore Geology Reviews, 27(1-4), 273-322. https://doi.org/10.1016/j.oregeorev.2005.07.008

Welin, E. (1987). The depositional evolution of the Sveccofennian supracrustal sequence in Finland and Sweden. Precambrian Research, 35, 95-113.

Westhues, A., Hanchar, J. M., Whitehouse, M. J., \& Martinsson, O. (2016). New constraints on the timing of host-rock emplacement, hydrothermal alteration, and iron oxide-apatite mineralization in the Kiruna District, Norrbotten, Sweden. Economic Geology, 111(7), 15951618. https://doi.org/10.2113/econgeo.111.7.1595

Williams, P. J. (1994). Iron mobility during synmetamorphic alteration in the Selwyn Range area, NW Queensland: implications for the origin of ironstone-hosted $\mathrm{Au}-\mathrm{Cu}$ deposits. Mineralium Deposita, 29(3), 250-260. https://doi.org/10.1007/BF00206868

Williams, P J, Barton, M. D., Johnson, D. A., Fontboté, L., de Haller, A., Mark, G., Oliver, N. H. S., \& Marschik, R. (2005). Iron oxide copper-gold deposits: Geology, space-time distributions, and possible modes of origin. Economic Geology, 100, 371-405. 
Williams, P. J., \& Skirrow, R. G. (2000). Overview of iron oxide-copper-gold deposits in the Curnamona Province and Cloncurry district (Mount Isa Block), Australia. In T. M. Porter (Ed.), Hydrothermal iron oxide copper-gold and related deposits: A global perspective, Volume 1 (pp. 105-122). Australian Mineral Foundation.

Williams, Patrick J. (1998). Metalliferous economic geology of the Mt Isa Eastern Succession, northwest Queensla. Australian Journal of Earth Sciences, 45, 329-341.

Willis, I. L., Brown, R. E., Stroud, W. J., \& Stevens, B. P. J. (1983). The Early Proterozoic Willyama Supergroup: Stratigraphic subdividion and interpretation of high- to low-grade grade metamorphic rocks in the Broken Hill block, New South Wales. Geological Society of Australia Journal, 30, 195-224.

Wilson, N. S. F., Zentilli, M., Reynolds, P. H., \& Boric, R. (2003). Age of mineralization by basinal fluids at the El Soldado manto-type copper deposit, Chile: 40Ar/39Ar geochronology of K-feldspar. Chemical Geology, 197(1-4), 161-176. https://doi.org/10.1016/S0009-2541(02)00350-9

Wyborn, L. A. I., Budd, A. R., \& Bastrakova, I. v. (1998). Metallogenic potential of felsic igneous rocks of the Tennant Creek and Davenport Provinces, Northern Territory. AGSO Research Newsletter, 29, 26-28.

Xavier, R. P., Monteiro, L. V. S., Souza Filho, C. R., Torresi, I., Carvalho, E. R., Dreher, A. M., Wiedenbeck, M., Trumbull, R. B., Pestilho, A. L. S., \& Moreto, C. P. N. (2010). The iron oxide copper-gold deposits of the Carajás mineral province, Brazil: An updated and critical review. In T. M. Porter (Ed.), Hydrothermal iron oxide copper-gold and related deposits: A global perspective, Volume 3 (pp. 285-306). PGC Publishing.

Zeng, M., Zhang, D., Zhang, Z., Li, T., Li, C., \& Wei, C. (2018). Structural controls on the Lala iron-copper deposit of the Kangdian metallogenic province, southwestern China: Tectonic and metallogenic implications. Ore Geology Reviews, 97(July 2017), 35-54. https://doi.org/10.1016/j.oregeorev.2018.04.028

Zhao, X. F., \& Zhou, M. F. (2011). Fe-Cu deposits in the Kangdian region, SW China: A Proterozoic IOCG (iron-oxide-copper-gold) metallogenic province. Mineralium Deposita, 46(7), 731-747. https://doi.org/10.1007/s00126-011-0342-y

Zhao, X. F., Zhou, M. F., Li, J. W., Selby, D., Li, X. H., \& Qi, L. (2013). Sulfide Re-Os and Rb-Sr isotope dating of the Kangdian IOCG metallogenic province, southwest China: Implications for regional metallogenesis. Economic Geology, 108(6), 1489-1498. https://doi.org/10.2113/econgeo.108.6.1489

Zhao, X. F., Zhou, M. F., Su, Z. K., Li, X. C., Chen, W. T., \& Li, J. W. (2017). Geology, geochronology, and geochemistry of the Dahongshan Fe-Cu-(Au-Ag) deposit, southwest China: Implications for the formation of iron oxide copper-gold deposits in intracratonic rift settings. Economic Geology, 112(3), 603-628. https://doi.org/10.2113/econgeo.112.3.603

Zhou, M. F., Yan, D. P., Kennedy, A. K., Li, Y., \& Ding, J. (2002). SHRIMP U-Pb zircon geochronological and geochemical evidence for Neoproterozoic arc-magmatism along the western margin of the Yangtze Block, South China. Earth and Planetary Science Letters, 196(1-2), 51-67. https://doi.org/10.1016/S0012-821X(01)00595-7

Zhou, M. F., Zhao, X. F., Chen, W. T., Li, X. C., Wang, W., Yan, D. P., \& Qiu, H. N. (2014). Proterozoic Fe-Cu metallogeny and supercontinental cycles of the southwestern Yangtze Block, southern China and northern Vietnam. Earth-Science Reviews, 139, 59-82. https://doi.org/10.1016/j.earscirev.2014.08.013

Zhu, L., Liu, J., Bagas, L., Carranza, E. J. M., Zhai, D., Meng, G., Wang, J., Wang, Y., Zhang, F., \& Liu, Z. (2019). The Yinachang Fe-Cu-Au-U-REE deposit and its relationship with intermediate to mafic intrusions, SW China: Implications for ore genesis and geodynamic setting. Ore Geology Reviews, 104(November 2018), 190-207. https://doi.org/10.1016/j.oregeorev.2018.11.005 